\title{
PHYTOSOCIOLOGY AND ECOLOGY OF THE DINARIC FIR-BEECH FORESTS (OMPHALODO- FAGETUM) AT THE NORTH-WESTERN PART OF THE ILLYRIAN FLORAL PROVINCE (NW DINARIC ALPS)
}

\author{
Boštjan SURINA ${ }^{1} \&$ Igor DAKSKOBLER ${ }^{2}$
}

\begin{abstract}
We studied the phytosociology, ecology and biogeography of the Dinaric fir-beech stands (Omphalodo-Fagetum) in the Trnovski gozd plateau, at the north-western part of the Illyrian floral province. We identified and confirmed two geographical variants (var. geogr. Saxifraga cuneifolia - central and western part of the plateau, and var. geogr. Calamintha grandiflora - eastern part of the plateau), and 10 floristically and ecologically well differentiated subassociations (-rhododendretosum hirsuti,-saxifragetosum cuneifoliae, -adenostyletosum glabrae, -festucetosum altissimae, -calamagrostietosum arundinaceae, -stellarietosum montanae, -seslerietosum autumnalis, -calamagrostietosum variae, -sambucetosum nigrae and -asaretosum europei). The most frequent stands bellong to the subassociation -festucetosum altissimae and -calamagrostietosum arundinaceae, which, in terms of site ecology and floristic composition, represent the central forest types in the research area. They are floristically impoverished and lack majority of association's characteristic species which is in line with the biogeographic peculiarites of the research area.

Key words: Aremonio-Fagion, biogeography, Dinaric Alps, Illyrian floral province, Fir-Beech forest, OmphalodoFagetum, Trnovski gozd plateau, phytosociology, vegetation.

\section{Izvleček}

Podali smo fitocenološko, ekološko in biogeografsko oznako gozdov bukve in jelke (Omphalodo-Fagetum) v Trnovskem gozdu, ki v biogeografskem oziru predstavlja severozahodni rob Ilirske florne province. Ugotovili in potrdili smo dve geografski varianti (var. geogr. Saxifraga cuneifolia - osrednji in zahodni del planote in var. geogr. Calamintha grandiflora - vzhodni del planote) in 10 subasociacij, ki se floristično in okoljsko dobro razlikujejo (-rhododendretosum hirsuti, -saxifragetosum cuneifoliae, -adenostyletosum glabrae, -festucetosum altissimae, -calamagrostietosum arundinaceae, -stellarietosum montanae, -seslerietosum autumnalis, -calamagrostietosum variae, -sambucetosum nigrae in -asaretosum europei). Osrednjo in najbolj pogosto obliko dinarskih jelovo bukovih gozdov predstavljajo sestoji -festucetosum altissimae in -calamagrostietosum arundinaceae. Sestoji teh subasociacij so floristično obubožani, zastopanost značilnih vrst dinarskega gozda jelke in bukve pa najmanjša, kar je skladno $\mathrm{z}$ biogeografskimi značilnostmi območja.

Ključne besede: Aremonio-Fagion, biogeografija, Dinaridi, Ilirska florna provinca, jelovo-bukov gozd, Omphalodo-Fagetum, Trnovski gozd, fitocenologija, vegetacija.
\end{abstract}

\footnotetext{
${ }^{1}$ University of Primorska, Faculty of Mathematics, Natural Sciences and Information Technologies, Glagoljaška 8, SI-6000 Koper, Slovenia, bostjan.surina@prirodoslovni.com

${ }^{2}$ Institute of Biology, Scientific Research Centre of the Slovenian Academy of Sciences and Arts, Regional unit Tolmin, Brunov drevored 13, SI-5220 Tolmin, Slovenia, igor.dakskobler@zrc-sazu.si
} 


\section{INTRODUCTION}

\subsection{Fir-BEECH STANDS IN THE NORTH- western Dinaric Alps (OMphalodo- FAGETUM S. LAT.)}

Dinaric Alps, streching between South-eastern Calcareous Alps and the Pindos mountain range, represent a backbone of the Illyrian floral province of the Central European floral region. Circumscribed on the basis of classical biogeographical principles (Beck 1901, Adamović 1909, Horvat et al. 1974), Illyrian floral province is recognised by considerable number of Balkan and local (narrow) endemics as well as the taxa restricted to the Dinaric Alps only. As pointed out by Šercelj (1996), and based on palinological data, the area served as a forest refugium during the Pleistocene climatic oscillations. Recent evidence in molecules, combined with the results of the analyses of charcoal and pallinological data as well as analysis of floristic composition of stands furtherly support Šercelj's statement and suggest several glacial refugia for European beech (Fagus sylvatica) in southern Europe and in the area of NW Dinaric Alps and South-eastern Calcareous Alps in particular (e.g., Taberlet et al. 1998, Brus et al. 2000, Willis \& van Andel 2004, Magri et al. 2006, Willner et al. 2009, but for the recent review see Brus 2010).

One of the most prominent characteristics of the area are more or less preserved European beech forests covering huge areas of the Dinaric Alps. They are characterised by number of $\gg$ Illyrian« forest species or »illyricoid elements« (sensu Trinajstić 1997) thus syntaxonomically belonging to Illyrian alliance Aremonio-Fagion (Borhidi 1963, Borhidi 1965, Török et al. 1989, Marinček et al. 1993). In the (alti)montane belt, fir-beech stands (»Abieti-Fagetum« s. lat.) generaly prevail (e.g., Horvat 1938, Tregubov 1941, 1957, Vukelić et al. 2008, Dakskobler 2008, Dakskobler \& Marinšek 2009) representing the climax vegetation type and due to high level of biodiversity and socio-economic importance (wood production, hunting, turism, etc.) also an important aspect of natural and cultural heritage of the area. Phytosociologically, these forests are one of the most studied in the western Balkans and their ecology, biogeography, syntaxonomy and typology are rather well known (see Markgraf 1927, Horvat 1938, 1957, Fukarek \& Stefanović 1958, Blečić 1958, Fukarek 1964, Bertović et al. 1966, Trinajstić 1970, 1972,
Puncer et al. 1974, Pelcer 1976, Puncer 1980, Zupančič \& Puncer 1995, Vukelić \& Baričević 1996, Accetto 1998, Marinček \& Košir 1998, Dakskobler et al. 2000, Surina 2001, 2002, Vukelić \& Baričević 2002). Depending on general ecological conditions (e.g. geological bedrock, soil type, inclination, exposition, elevation, ...), Dinaric firbeech forests are on their lower elevational limit in contact with montane beech forests of the associations Lamio orvalae-Fagetum, Arunco-Fagetum, Hacquetio-Fagetum, Seslerio autumnalis-Fagetum, Ostryo-Fagetum, Rhododendro hirsuti-Fagetum (compare with Dakskobler 2008), pine forests of the associations Rhododendro hirsuti-Pinetum prostratae and Fraxino orni-Pinetum nigrae or even directly with thermophitic European Hop-hornbeam forests of the associations Seslerio autumnalis-Ostryetum and Amelanchiero ovalis-Ostryetum. On their upper elevational limit, however, they are in contact with altimontane (Ranunculo platanifolii-Fagetum) and subalpine (Polysticho lonchitis-Fagetum) beech forests, forming frequently both on the upper and lower limits of their elevational range transitional stands of ambiguous tipology. Latitudinally, on their north-western limits of their distribution range (the Trnovski gozd plateau), they are in contact with pre-alpine fir-beech stands of the association Homogyno sylvestris-Fagetum. The southern limit of the distribution range of the association Omphalodo-Fagetum, as well as the whole alliance Aremonio-Fagion, is not clear yet (for the relevant discussion see Surina 2002) and an extensive analysis in order the define its south-eastern limits awaits.

Dinaric fir-beech stands in the Illyrian floral province, initially described as Fagetum croaticum australe abietetosum by Horvat (1938), Tregubov (1957) lately treated on the association rank (Abieti-Fagetum dinaricum). Following the rules of a phytosociological code (Barkman et al. 1986, but see also Weber et al. 2000), Marinček et al. (1993) did the nomenclatorial revision of some of the Illyrian forest syntaxa and the name AbietiFagetum dinaricum was replaced by OmphalodoFagetum. However, as pointed out subsequently, nomenclatorial and chorological issues were not entierly solved (Surina 2002). Recent treatments and interpretations (Trinajstić 2008, Trinajstić et al. 2009) appeared to be redundand, missing the point, and by proposing a new name, FagoAbietetum omphalodetosum, missinterpreting and violating the phytosociological code (Weber et al. 2000) in several articles. 
Floristic differences and phytogeographical peculiarities of stands of Omphalodo-Fagetum at the northwestern part of the Dinaric Alps were firstly discussed by Wraber $(1953,1959)$ and lately by Puncer (1979), who reported on lower proportion of South-east European - Illyrian (illyricoid), and higher proportion of south-eastern Alpine taxa in Dinaric fir-beech stands at the north-westernmost part of its distribution area (Abieti-Fagetum austroalpinum nom. nud.) in the Trnovski gozd plateau. Unfortunatelly, Puncer's early death prevented him to continue the research and publish the results supplemented with the table material. Extensive phytogeographical analysis of stands of the association OmphalodoFagetum through all the distribution range proved floristic distinctions and led to recognition of the two geographical variants (Surina 2002): Omphalodo-Fagetum var. geogr. Saxifraga cuneifolia (restricted to northwesternmost part of the Dinaric Alps, majority of the Trnovski gozd plateau), and Omphalodo-Fagetum var. geogr. Calamintha grandiflora (easternmost part of the research area and the rest of the distribution range of the association). In this paper we follow the footsteps of Puncer furtherly trying to elucidate the phytosociological, ecological and phytogeographical characteristics of Dinaric fir-beech stands at the north-western part of the Illyrian floral province.

\subsection{Study AREA}

Trnovski gozd is a high karst plateau between 800-1200 m a.s.l. extending on app. $120 \mathrm{~km}^{2}$ at the north-western most part of the Dinaric Alps (W Slovenia, Figure 1). The highest peaks are found in it's central part (Mali Golak, $1495 \mathrm{~m}$ ). Except for the eastern (and partly north-western) side, the flanks of the plateau are steep and intersepted by precipited walls. Jurassic limestone prevails in the area. However, Cretaceous platy limestone with addition of chert is present in some dolinas and slopes, e.g. Mala Lazna, Velika Lazna, Avška Lazna and Gospodova senožet, while Triassic dolomites and Dachstein's limestones occur only on the north-eastern part of the plateau (Buser 1965). Among soils, most common types are different forms of rendzinas and mosaics of rendzinas and brown calcareous soils (Vovk et al. 1966). The climate is humid with high amount of precipitations, 2000-3000 mm yearly (Zupančič 1995), and on account of the

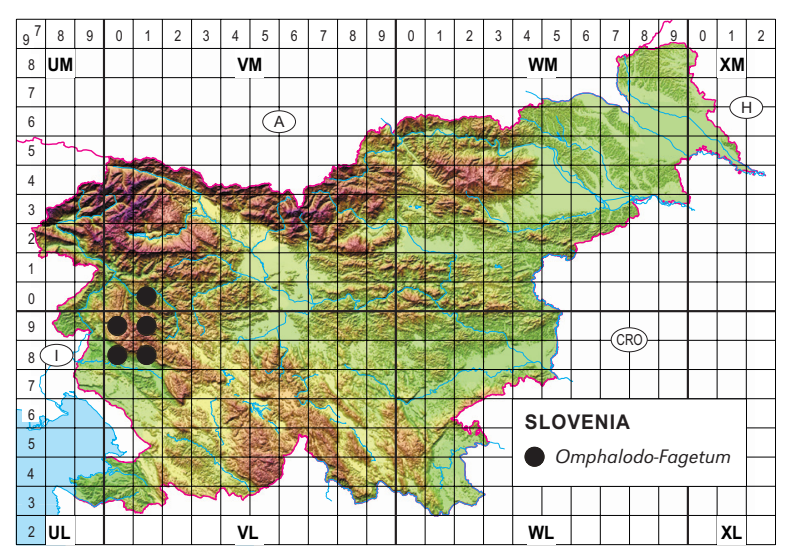

Figure 1: Research area and distribution of Dinaric fir-beech forests (Omphalodo-Fagetum) at northwesternmost part of the Dinaric Alps.

Slika 1: Območje raziskav in razširjenost dinarskih jelovo bukovih gozdov (Omphalodo-Fagetum) na skrajnem severozahodnem delu Dinaridov.

higher elevation of the plateau, karst relief, windness and abundant rainfall, relatively cold. Mean yearly temperature of the plaeau is estimated to be around $5{ }^{\circ} \mathrm{C}$ (Zupančič 1980), but is considerably higher at the western and southern part of the plateau. One of the characteristics of the plateau is a phenomenon of temperature and vegetation inversion frequently occuring in freezing dolines (e.g., Krašan 1880, Beck 1906, Martinčič 1977, Surina \& Vreš 2009).

\subsection{Forest Vegetation of the Trnovski GOZD PLATEAU}

Being in close proximity both to the Alps and the Adriatic Sea, the biogeographic aspect of the flora and vegetation of northwesternmost part of the Dinaric Alps attracted botanists from early beggining (for the review see Wraber 2004). However, majority of botanical studies were done on phytosociology of forest vegetation. M. Wraber did the first studies in 1950's and 60's (Wraber 1953, 1959, 1963), followed by Piskernik (1954) and Zupančič $(1967,1969)$ who studied maplebeech forests (Stellario glochidispermae-Fagetum = Stellario montanae-Fagetum). Extensive mapping of forest vegetation (in a scale $1: 10.000$ ) was performed between 1977-79 (Marinček et al. 1977, Čampa 1978, Urbančič et al. 1979). Spruce (Lonicero caeruleae-Piceetum, Hacquetio-Piceetum) and fir-spruce forests (Ribeso alpini-Piceetum) were studied in detail by Zupančič $(1980,1999)$ 
and Zupančič and Accetto (1994), respectivelly. Subalpine beech stands (Polysticho lonchitis-Fagetum var. geogr. Allium victorialis) were studied by Marinček (1996), while Dakskobler (1997, 1998, 2000, 2003) and Dakskobler et al. (2000) have done extensive studies on various types of beech forests: termophilous (Seslerio autumnalisFagetum), fir-beech (Omphalodo-Fagetum), and beech forests with hairy alpenrose (Rhododendro hirsuti-Fagetum). Native pine forests (Fraxino orniPinetum nigrae) are restricted only to precipited walls and terrases of northern slopes of the plateau above the Trebuša valley (Dakskobler 1999, 2004, Urbančič \& Dakskobler 2001). In general, beech forests completely prevail in the Trnovski gozd plateau, while fir-beech stands (OmphalodoFagetum var. geogr. Saxifraga cuneifolia) cover app. $70 \%$ of the research area (Turk 1994).

\section{METHODS}

Forest stands were studied applying sigmatistic method (Braun-Blanquet 1964, Westhoff \& van der Maarel 1973, Dierschke 1994). Plot size used for sampling was $400 \mathrm{~m}^{2}$ (a standard plot size for forest stands, but see also Chytry \& Otýpková 2003). All in all 208 relevés were entered into the FloVegSi database (Seliškar et al. 2003), 15 of which were already published by Dakskobler et al. (2000) - Omphalodo-Fagetum rhododendretosum hirsuti, and 35 of which originated from the unpublished manuscript of Puncer. Relevés were then compared using methods of hierarchical and non-hierarchical classification as well as ordination with help of the computer programme packages PAST (Hammer et al. 2001) and SYNTAX (Podani 2001). Prior to the analyses, the combined cover-abundance values were transformed into the ordinal scale as proposed by van der Maarel (1979).

In the first step we applyed non-hierarchical clustering (global optimisation with k values ranging from 2-10, 5 repeats and 100 searches), suitable for large datasets (Gauch 1999), in order to achieve within-cluster homogeneity. After initial non-hierarchical clustering we used several methods of hierarchical clustering (complete linkage farthest neighbour, unweighted average linkage method - UPGMA, incremental sum of squares - MISSQ) which all yielded very similar results. The similarity measures were Dice and Jaccard indices (when presence or absence of species was considered), Euclidian distance and Wishart's coefficient - similarity ratio. The arrangements of relevés in phytosociological tables is based on the results of hierarchical clustering. For every taxon in the table we calculated its cover index $(\mathrm{I})$ as suggested by Lausi et al. (1982). In order to explain the variation by specific environmental and structural (phytosociological) variables, unconstrained (PCA, DCA) and constrained (RDA, CCA) ordination analyses were performed using CANOCO computer programme (Braak Ter \& Šmilauer 2002). In order to determine the lenghts of gradientes, DCA analyses, detrended by segments, were initially performed and the models (linear, unimodal) were used accordingly. Statistical significance of ecological variables $(p<0.05)$ was tested using Monte Carlo test with 499 permutations. Only significant variables were then analyzed together in order to produce a general view of environmental impact on floristic composition and structure of forest stands. For the general environmental affinities we used bioindicator values of vascular plants of the Flora of Italy (Pignatti 2005). The environmental value in a relevé $\left(\mathrm{EV}_{\mathrm{w}}\right)$ was estimated as a weighted average of the indicator values of all the $s$ present species, their abundances being used as weights:

$$
\mathrm{EV}_{w}=\frac{\sum_{i=1}^{S} I V_{i} x \text { Abund }_{i}}{\sum \text { Abund }_{i}}
$$

where $I V_{i}$ is the indicator value of $i$ th species and Abund $_{i}$ is the abundance of $i$ th species in a relevé (Lepš \& Šmilauer 2003). In order to investigate whether a slope exposition of studied stands is randomly distributed within stands grouped to syntaxa recognized based on floristic composition, a directional analysis was performed using Rayleigh's - R (Mardia 1972) and chi-square $\mathrm{H}^{2}$ tests (Hammer \& Harper 2006) by means of programme package PAST.

Five representative soil profiles were used in order to explain soil conditions in different types of stands. Profiles were described by M.Sc. Tomaž Prus, and the chemical analyses were conducted in the laboratories of the Pedology and Environment Protection Centre of the Biotechnical Faculty, University of Ljubljana.

The association Omphalodo-Fagetum was subdivided into lower units according to the principle of multi-dimensional subdivision of vegetation units (Matuszkiewicz \& Matuszkiewicz 
1981, but see also Surina 2002). According to this principle geographical variants are treated as small independant regional associations and subassociations are discribed within the geographical variants (for example Omphalodo-Fagetum var. geogr. Saxifraga cuneifolia festucetosum altissimae) and not within the association in broader sense (Omphalodo-Fagetum festucetosum altisimae), what is in accordance to the Code (Weber et al. 2000). We find this approach in geographically widespread and climazonal associations to be practical and justified, being aware of the fact that certain newly described subassociations, according to the Code, are typified illegitimately.

The nomenclature and taxonomy of vascular plants is in agreement with the Mala flora Slovenije (Martinčič et al. 2007), while mosses and lichens with Martinčič (2003) and Suppan \& al. (2000), respectively. Phytosociological groups were formed on the basis of our own criteria, but in accord with numerous authors (e.g., Mucina et al. 1993, Oberdorfer 1994, Aeschimann et al. 2004). Type relevés for various syntaxa bellow the association rank are marked with an asterix. Taxa occuring only once in phytosociological tables, detailed locality descriptions and all the syntaxonomical units with complete names mentioned in the paper are listed in the Appendix. Since only the most frequent and abundant taxa of mosses and lichens were determined, mosses and lichens were not chosen for the diagnostic group of taxa. Their inventory is listed at the bottom of the analytical tables (Tables 5-14).

\section{RESULTS}

\subsection{FlORISTIC COMPOSITION}

Complete floristic inventory of the Dinaric firbeech stands in the Trnovski gozd plateau is given in Tables 4-14 and Appendix. In total, 253 taxa of ferns and phanerogams were recorded. Characteristic taxa for the European beech forests (Fagetalia sylvaticae) represent the core group (Figure 2, Tables $1 \& 2$ ) of species in studied stands, constituting 24.1 (rhododendretosum hirsuti) $-46.3 \%$ (asaretosum europaei) of a total floristic inventory according to various lower ranked syntaxa. Beech forests taxa achieve the highest coverage values $\left(\mathrm{I}_{\mathrm{c}}\right)$, ranging from 357.2 (festucetosum altissimae II) - 1019 (asaretosum europaei), as well. Moderatelly acidophilous, subhi- grophilous and mesophilous taxa, characteristic of spruce forests (Vaccinio-Piceetea), are also frequent, representing 10.9 (asaretosum europaei) $24.4 \%$ (festucetosum altissimae II) of a total floristic inventory, and achieving rather high coverage values (330.2 - 717.8). They are good diferential species to pure beech stands which represent climax forest vegetation type in lower montane and subalpine belts. Tall herbs (Mulgedio-Aconitetea) represent 4.6 (sambucetosum) - 12\% (rhododendretosum), while highly diagnostic illyricoid taxa (Aremonio-Fagion) from Illyrian forests 5.3 (rhododendretosum) $-9.5 \%$ (asaretosum) of total species inventory (Table 1). A proportion and coverage of groups of taxa may vary a lot according to different types of Dinaric fir-beech forests recognized in our analyses which is in accordance with general cognition of extreme ecological plasticity of forests of the climazonal association Omphalodo-Fagetum.

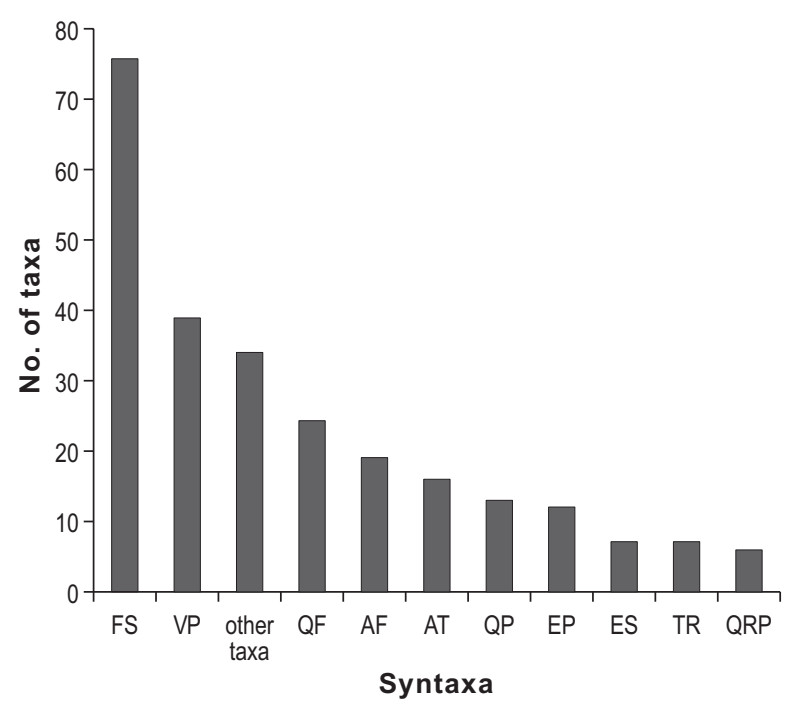

Figure 2: Number of taxa per selected syntaxa in Dinaric firbeech forests (Omphalodo-Fagetum) in the Trnovski gozd plateau (NW Dinaric Alps; FS - Fagetalia sylvaticae, VP - Vaccinio-Piceetea, QF - Querco-Fagetea, AF - Aremonio-Fagion, AT - Asplenietea trichomanis, QP - Quercetalia pubescentis, EP - Erico-Pinetea, ES - Elyno-Seslerietea, TR - Thlaspietea rotundifolii, QRP - Quercetalia robori-petraeae).

Slika 2: Število taksonov v dinarskem jelovem bukovju (Omphalodo-Fagetum) v Trnovskem gozdu (severozahodni Dinaridi) glede na izbrane sintaksonomske skupine (FS Fagetalia sylvaticae, VP - Vaccinio-Piceetea, QF - QuercoFagetea, AF - Aremonio-Fagion, AT - Asplenietea trichomanis, QP - Quercetalia pubescentis, EP - Erico-Pinetea, ES - ElynoSeslerietea, TR - Thlaspietea rotundifolii, QRP - Quercetalia robori-petraeae). 
Table 1: Syntaxonomic groups $\left(\%^{\text {Ic }}\right)$ in the subassociations of the Dinaric fir-beech forests (Omphalodo-Fagetum) in the Trnovski gozd plateau (NW Dinaric Alps).

Tabela 1: Sintaksonomske skupine $\left(\%{ }^{\text {Ic }}\right)$ v subasociacijah dinarskega jelovega bukovja s klinolistnim kamnokrečem (Omphalodo-Fagetum) v Trnovskem gozdu (severozahodni Dinaridi).

\begin{tabular}{|c|c|c|c|c|c|c|c|c|c|c|c|}
\hline Syntaxa & rho & ade & $\operatorname{sax}$ & cal aru & fes I & fes II & ste & cal var & ses & sam & asa \\
\hline Aremonio-Fagion & $5.3^{127.1}$ & $7.7^{85.2}$ & $6.7^{91.7}$ & $7.0^{108.5}$ & $5.9^{113.3}$ & $6.9^{76.1}$ & $6.5^{110.1}$ & $7.9^{134.5}$ & $9.3^{134.7}$ & $8.3^{170.8}$ & $9.5^{193.7}$ \\
\hline Fagetalia sylvaticae & $24.1^{439.6}$ & $36.9^{593.8}$ & $30.6^{433.3}$ & $35.9^{561.4}$ & $38.5^{645.8}$ & $34.4^{357.2}$ & $41.3^{862.4}$ & $33.5^{630.0}$ & $37.3^{489.6}$ & $43.1^{550.0}$ & $46.3^{1019.0}$ \\
\hline Quercetalia pubescentis & $3.0^{37.5}$ & $3.1^{0.0}$ & $4.5^{26.1}$ & $3.5^{22.9}$ & $3.7^{7.6}$ & $4.6^{6.2}$ & $4.5^{7.4}$ & $4.9^{35.7}$ & $6.8^{104.2}$ & $2.8^{16.7}$ & $5.4^{66.7}$ \\
\hline Quercetalia roboris-petraeae & & & & & & $0.8^{0.8}$ & & & $0.8^{1.4}$ & & $2.7^{15.9}$ \\
\hline Querco-Fagetea & $5.3^{66.0}$ & $2.3^{37.0}$ & $6.0^{70.6}$ & $6.3^{52.0}$ & $6.7^{41.3}$ & $5.3^{33.3}$ & $7.7^{52.9}$ & $7.9^{74.5}$ & $6.8^{59.7}$ & $5.5^{66.7}$ & $8.8^{149.2}$ \\
\hline Erico-Pinetea & $6.0^{109.0}$ & $3.8^{16.0}$ & $3.0^{17.8}$ & $2.1^{2.6}$ & $2.2^{0.9}$ & $1.5^{0.8}$ & $1.9^{1.6}$ & $4.9^{91.7}$ & & $2.8^{11.1}$ & $1.4^{12.7}$ \\
\hline Mulgedio-Aconitetea & $12.0^{154.2}$ & $10.8^{144.4}$ & $9.0^{36.1}$ & $7.7^{10.8}$ & $6.7^{23.1}$ & $6.9^{3.3}$ & $9.7^{149.2}$ & $7.9^{71.4}$ & $5.9^{4.2}$ & $4.6^{8.3}$ & $4.8^{30.2}$ \\
\hline Vaccinio-Piceetea & $23.3^{653.5}$ & $20.0^{224.1}$ & $23.1^{717.8}$ & $20.4^{466.7}$ & $20.0^{316.0}$ & $24.4^{357.2}$ & $12.9^{170.9}$ & $14.0^{207.3}$ & $20.3^{286.1}$ & $18.3^{306.9}$ & $10.9^{330.2}$ \\
\hline Elyno-Seslerietea & $2.3^{34.0}$ & $2.3^{13.6}$ & $0.7^{1.1}$ & & & & & $3.0^{20.2}$ & & & $0.7^{3.2}$ \\
\hline Asplenietea trichomanis & $9.8^{131.9}$ & $6.9^{43.2}$ & $7.5^{122.8}$ & $6.3^{84.0}$ & $6.7^{49.8}$ & $5.3^{38.7}$ & $4.5^{39.2}$ & $6.1^{67.1}$ & $5.9^{63.2}$ & $4.6^{47.2}$ & $2.7^{31.7}$ \\
\hline Thlaspietea rotundifolii & $2.3^{40.3}$ & $0.8^{30.9}$ & $1.5^{36.3}$ & $2.1^{28.4}$ & $1.5^{19.1}$ & $0.8^{24.3}$ & $0.6^{7.9}$ & $1.8^{36.3}$ & $1.7^{24.3}$ & $0.9^{2.8}$ & $0.7^{1.6}$ \\
\hline Other species & $6.8^{70.8}$ & $5.4^{60.5}$ & $7.5^{77.2}$ & $8.5^{93.8}$ & $8.1^{82.7}$ & $9.2^{64.2}$ & $10.3^{75.1}$ & $7.9^{40.8}$ & $5.1^{50.0}$ & $9.2^{172.2}$ & $6.1^{63.5}$ \\
\hline No. of ferns and seed plants & $133^{1863.9}$ & $130^{1248.8}$ & $118^{1630.7}$ & $132^{100.0}$ & $135^{1299.5}$ & $131^{962.1}$ & $137^{1476.7}$ & $164^{1409.5}$ & $118^{1217.4}$ & $109^{1352.8}$ & $147^{1917.5}$ \\
\hline $\begin{array}{l}\text { Mean no. of seed plants/ } \\
\text { relevé, CV \% }\end{array}$ & $65.3^{10.0}$ & $42.1^{14.8}$ & $51.5^{12.4}$ & $42.9^{13.7}$ & $42.8^{11.5}$ & $34.3^{19.3}$ & $45.4^{16.1}$ & $50.6^{20.0}$ & $41.9^{11.6}$ & $58^{7.4}$ & $57.9^{13.9}$ \\
\hline Nom. od lichens and bryophytes & $53^{475.7}$ & $31^{219.1}$ & $48^{209.4}$ & $17^{131.7}$ & $16^{123.1}$ & $33^{205.8}$ & $45^{189.9}$ & $17^{124.5}$ & $22^{156.3}$ & $15^{122.2}$ & $21^{182.5}$ \\
\hline
\end{tabular}

Table 2: Phytosociological parameters (Me-Min-Max) of different types of Dinaric fir-beech stands (OmphalodoFagetum) in the Trnovski gozd plateau (NW Dinaric Alps).

Tabela 2: Fitocenološki parametri (Me-Min-Max) različnih tipov dinarskega jelovega bukovja (Omphalodo-Fagetum) v Trnovskem gozdu (severozahodni Dinaridi).

\begin{tabular}{|c|c|c|c|c|c|c|c|}
\hline \multirow[b]{2}{*}{ syntaxa } & \multirow[b]{2}{*}{$\begin{array}{l}\text { elevation } \\
(\mathrm{m})\end{array}$} & \multirow[b]{2}{*}{$\begin{array}{l}\text { incl. } \\
(0)\end{array}$} & \multicolumn{5}{|c|}{ coverage $(\%)$} \\
\hline & & & $\begin{array}{l}\text { tree layer } \\
\text { (A) }\end{array}$ & $\begin{array}{l}\text { shrub layer } \\
\text { (B) }\end{array}$ & $\begin{array}{l}\text { herb layer } \\
\text { (C) }\end{array}$ & $\begin{array}{l}\text { moss layer } \\
\text { (D) }\end{array}$ & $\begin{array}{l}\text { stoniness } \\
\text { (S) }\end{array}$ \\
\hline rhododendretosum hirsuti & $1305^{1130-1350}$ & $35^{25-35}$ & $70^{60-80}$ & $50^{20-60}$ & $60^{40-70}$ & $20^{10-30}$ & $60^{0-70}$ \\
\hline adenostyletosum glabrae & $1270^{1240-1300}$ & $25^{0-40}$ & $85^{70-90}$ & $10^{1-60}$ & $60^{40-70}$ & $10^{5-20}$ & $30^{10-60}$ \\
\hline saxifragetosum cuneifoliae & $1195^{1035-1340}$ & $40^{0-50}$ & $80^{50-100}$ & $20^{5-60}$ & $75^{70-100}$ & $10^{1-50}$ & $30^{10-70}$ \\
\hline calamagrostietosum arundinaceae & $1130^{945-1245}$ & $20^{0-50}$ & $90^{70-100}$ & $20^{5-70}$ & $70^{40-90}$ & $10^{5-40}$ & $30^{1-70}$ \\
\hline festucetosum altissimae I & $1010^{790-1275}$ & $15^{0-40}$ & $100^{70-100}$ & $10^{1-50}$ & $70^{30-100}$ & $10^{1-50}$ & $30^{1-70}$ \\
\hline festucetosum altissimae II & $1040^{790-1220}$ & $5^{0-30}$ & $80^{70-90}$ & $10^{0-40}$ & $60^{30-90}$ & $10^{0-60}$ & $60^{0-80}$ \\
\hline stellarietosum montanae & $970^{800-1100}$ & $15^{0-35}$ & $80^{50-100}$ & $10^{1-90}$ & $80^{50-100}$ & $10^{1-50}$ & $20^{0-70}$ \\
\hline calamagrostietosum variae & $960^{680-1200}$ & $35^{20-40}$ & $80^{70-90}$ & $20^{10-40}$ & $50^{10-70}$ & $5^{0-20}$ & $20^{10-40}$ \\
\hline seslerietosum autumnalis & $970^{800-1120}$ & $17.5^{10-25}$ & $90^{80-100}$ & $10^{5-40}$ & $70^{10-100}$ & $10^{1-30}$ & $30^{5-60}$ \\
\hline sambucetosum nigrae & $850^{800-1000}$ & $20^{15-25}$ & $85^{80-100}$ & $50^{30-60}$ & $80^{70-90}$ & $10^{5-10}$ & $15^{5-20}$ \\
\hline asaretosum europaei & $660^{640-800}$ & $32.5^{30-35}$ & $90^{80-90}$ & $10^{10-20}$ & $55^{40-60}$ & $5^{5-20}$ & $15^{10-30}$ \\
\hline
\end{tabular}


Table 3: Chemical and physical characteristics of five representative soil profiles in five Dinaric fir-beech stands (Omphalodo-Fagetum) in the Trnovski gozd plateau (NW Dinaric Alps).

Tabela 3: Kemične in fizikalne lastnosti tal v petih reprezentativnih profilih v sestojih dinarskega jelovega bukovja (Omphalodo-Fagetum) v Trnovskem gozdu (severozahodni Dinaridi).

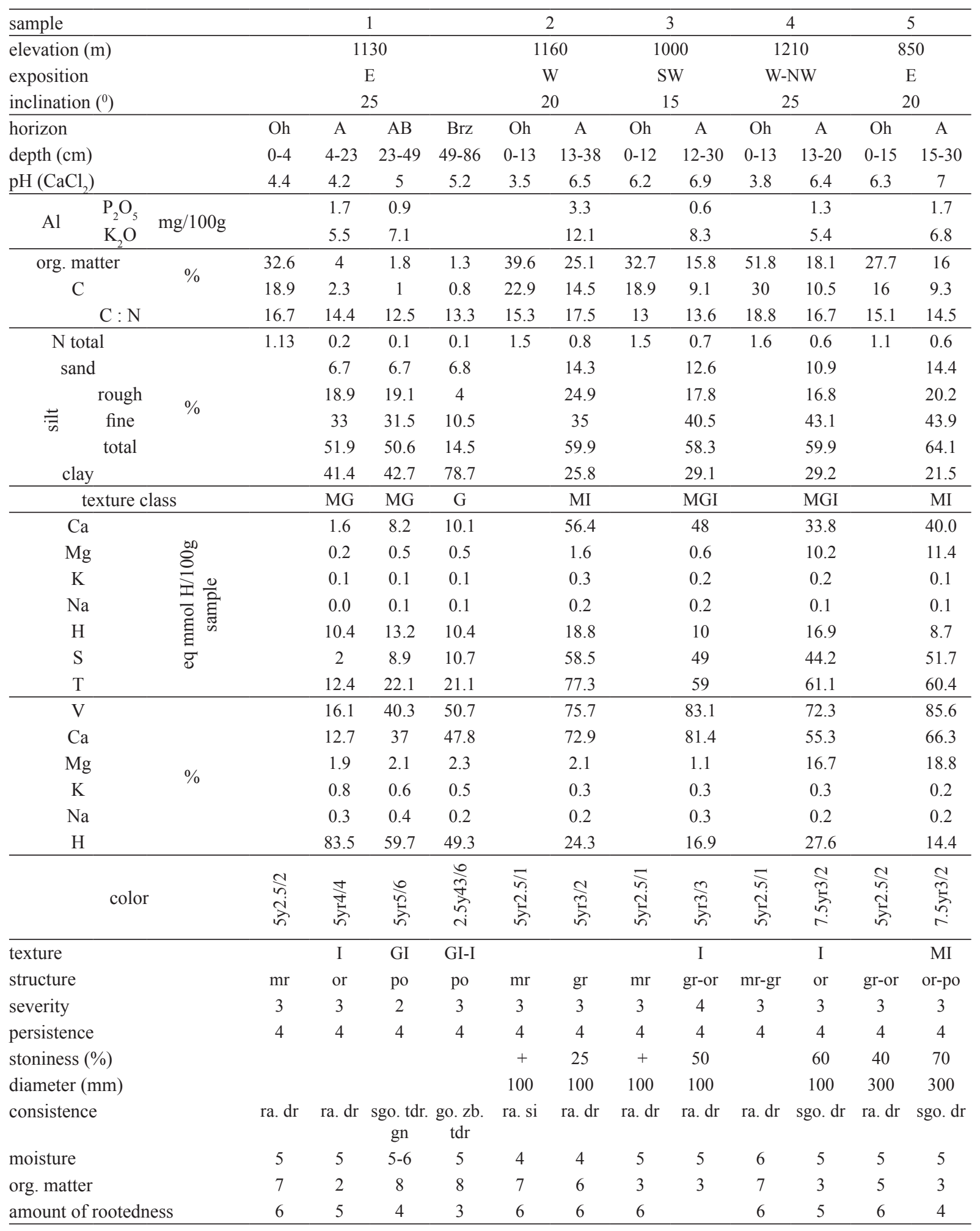




\subsection{FloristiG STRUCTURE OF STANDS}

In the tree layer, Fagus sylvatica and Abies alba (the latter specially in the upper tree layer) prevail, covering $70-100 \%$ of the relevé area. Although generally dependent on specific site ecology, the abundance and coverage ratio of fir and beech in stands are heavily influenced by management regime, since almost pure even-aged and unistructural beech stands, in otherwise sites of climazonal fir-beech stands, were frequently observed. In some stands, Acer pseudoplatanus and Picea abies are also frequent and relatively abundant, while Ulmus glabra and Tilia platyphyllos appear mostly in stands thriving on specific sites and on lower elevation of NE part of the study area. Sorbus aucuparia, $S$. aria and Ostrya carpinifolia only rarely occur in a tree layer, but rather frequently in a shrub layer. Shrubs in general cover 10-20 $(-50) \%$ of the relevé area and the most frequent species are Fagus sylvatica, Acer psedoplatanus, Abies alba and Picea abies. Other relativelly common taxa are Lonicera nigra, L. alpigena, Daphne mezereum, Rosa pendulina, Rubus idaeus, Sambucus nigra and $S$. racemosa. Rhododendron hirsutum, Sorbus chamaemespilus and Salix appendiculata are otherwise less frequent, but on ecologically extreme sites they significantly shape the structure and physiognomy of stands. Herb layer is rather well developed, covering $70-80 \%$ of the relevé area. European beech forest species and spruce forest species prevail. One of the characteristics of studied stands is presence of some SE-Alpine - N-Ilyrian elements, e.g., Phyteuma scheuchzeri ssp. columnae, Paederota lutea, Rhodothamnus chamaecistus, Primula carniolica, Laburnum alpinum, Saxifraga cuneifolia, rendering fir-beech stands in the Trnovski gozd plateau (OmphalodoFagetum var. geogr. Saxifraga cuneifolia) biogeographically transitional to SE-Alpine fir-beech stands (Homogyno sylvestris-Fagetum; Dakskobler et al. 2000, Surina 2002). Cryptophytes generally cover round $10 \%$ of the relevé area (but up to $60 \%$ ), depending on stoniness and moisture of sites. They are most abundant in rocky and moist sites (e.g., rhododendretosum, stellarietosum, Tables 1 \& 2), while in dry sites and those with low stoniness (e.g., seslerietosum autumnalis, asaretosum, sambucetosum) they use to cover $15-30 \%$ of the relevé area.

\subsection{CharaGteristic species of the ASSOCIATION}

According to Puncer (1980), Omphalodes verna, Calamintha grandiflora, Rhamnus fallax, Cardamine trifolia and Aremonia agrimonoides are relativelly good characteristic species of the association Omphalodo-Fagetum. However, in the northwesternmost part of the distribution area of the association they appear with lower frequency and coverage in comparisson to Dinaric fir-beech stands from the center of the association's distribution area (Omphalodo-Fagetum var. geogr. Calamintha grandiflora), a fact pointed out already by earlier phytosociologists studing the forest vegetation of the Trnovski gozd plateau (e.g., Wraber 1953, 1959, Marinček et al. 1977, Čampa 1978, Puncer 1979, Urbančič et al. 1979, Puncer 1980, Dakskobler et al. 2000; Surina 2002). In the central part of the plateau and majority of the research area, Calamintha grandiflora, Omphalodes verna and Rhamnus fallax occur only sporadically, while they are more frequent only at lower elevation of north-eastern (and partly in north-western part of the plateau, above Čepovanska dolina valley, in the syntaxon -stellarietosum montanae var. Cardamine pentaphyllos) part of the plateau, particularly in the subassociations -sambucetosum, -asaretosum and -calamagrostietosum variae (Table 4). On the other hand, Cardamine trifolia and Aremonia agrimonoides occur frequently and with high constancy in studied stands throughout the research area.

\subsection{Numerical ANALYSES}

Initially, both non-hierarchical (NHCL) and hierarchical (HCL) analyses identified the same groups of relevés. NHCL gave best results with $\mathrm{k}=3$ (criterion value $=0.83358$ ) and $\mathrm{k}=4$ (criterion value $=0.81854)$, while combination of several methods and measures of similarities identified three floristically and ecologically well defined groups of relevés (dendrogram not shown). The first group of relevés represents the most frigoriphilous stands thriving oh highest elevation and slopes exposed to the north. Rhododendron hirsutum is prevailing in approxmatelly half of the relevés in the understory. These stands were already described in detail by Dakskobler et al. (2000) and typified as Omphalodo-Fagetum var. geogr. Saxifraga cuneifolia rhododendretosum hir- 
suti. Within the same cluster and beside the stands with predominating Rhododendron hirsutum in the understory, there are stands with the highest coverage values of species of the class Vaccinio-Piceetea and the highest frequency and coverage value of Saxifraga cuneifolia. Most thermophilous stands and those thriving on lowest elevation are grouped within a second cluster; this cluster gathers stands where Sesleria autumnalis completely dominates in herb layer, while Stellaria montana, Impatiens noli-tangere, Lunaria rediviva, Sambucus nigra, etc. were frequent in most mesophilous stands of the cluster. The third cluster comprises majority of the relevés and is floristically and ecologically positioned inbetween the former two clusters. In the second step, the three clusters were analyzed separately by means of additional cluster analyses and various unconstrained and constrained ordination techniques. Their tipology is furtherly discussed in detail.

\subsection{SOIL PROFILES}

We identified considerable differences in soil depth already in a scale of only a few meters. Averagely, soil depth is very shallow and intersepted with bare rocks, stones and boulders. Homogeneously distributed soil types and depths on relatively larger areas were only rarely recorded in the field, thus rendering different soil types as not as most suitable ecological parameter to characterize and classify forest stands according to their floristic composition and soil properties. Nevertheless, analyses of representative soil profiles show significant differences both in physical and chemical characteristics according to different types of forest stands defined by numerical analyses (Figure 3, Table 3.

The profile No. 1 represents brown soil with pronounced mineral horizon (B), developed on calcareous bedrock intermixed with chert. In comparisson to other analyzed soil profiles (Table 3), the A horizon has the lowest $\mathrm{pH}$ valus and contains the lowest amount of calcium, magnesium, potassium, organic matter, nitrogen, sand and silt. On the other hand it contains the biggest amount of clay. By a rule, in Dinaric firbeech stands, developed on brown soils, Calamagrostis arundinacea prevails in the understory (Omphalodo-Fagetum var. geogr. Saxifraga cuneifolia calamagrostietosum arundinaceae). Other soil profiles represent rendzinas. The soil in profile

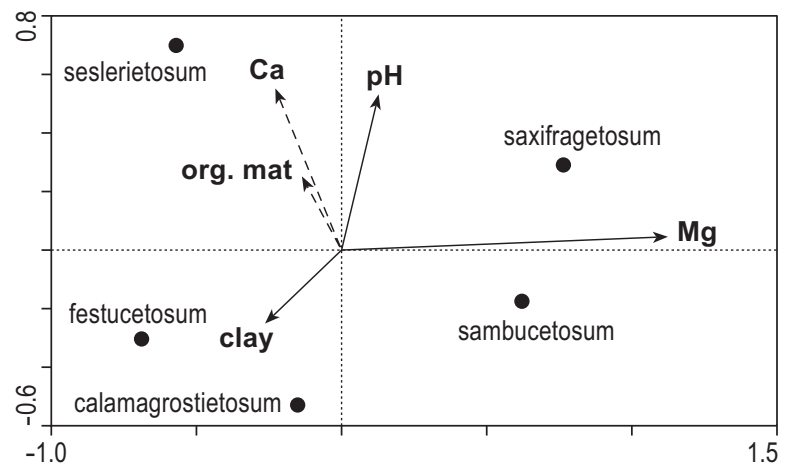

Figure 3: RDA of selective soil parameters in five different types of Dinaric fir-beech stands (Omphalodo-Fagetum) in the Trnovski gozd plateau (NW Dinaric Alps). For further detail see Table 1. F-ratio: $\mathrm{Mg}=1.52(\mathrm{p}=0.056)$, clay $=0.70$ ( $\mathrm{p}=0.796), \mathrm{pH}=0.69$ ( $\mathrm{p}=0.7980) ; 0.73$ variance explained by selected variables; supplementary variables $\mathrm{Ca}$ and org. mat.; eigenvalues $0.357,0.194,0.180,0.270$. Statisticaly insignificate variables are marked with dashed line.

Slika 3: RDA analiza na temelju izbranih pedoloških parametrov v petih različnih tipih dinarskega jelovega bukovja (Omphalodo-Fagetum) v Trnovskem gozdu (severozahodni Dinaridi). Podrobnejše informacije so v tabeli 1. F-razmerje $\mathrm{Mg}=1.52(\mathrm{p}=0.056)$, glina $=0.70 \quad(\mathrm{p}=0.796), \mathrm{pH}=0.69$ $(\mathrm{p}=0.7980)$; izbrane variable pojasnjujejo 0.73 variance; dodatne variable: Ca in org. del.; eigenvalues 0.357, 0.194, 0.180, 0.270 . Statistično neznačilne variable so označene s prekinjeno črto.

No. 2 is very shallow and represents the most common soil type in the research area. The A horizon contains the biggest amount of phosphorus and potassium, sand and silt, and the lowest amounts of clay. $\mathrm{O}_{\mathrm{f}}$ horizon is well developed and densely crisscrosed with mycelium. The geological bedrock is limestone. This type of soil is most frequently developed on steep and rocky slopes arranged in cascades preferably of northern exposition, on ridges and mountain tops of higher elevation. In stands developed on this type of soils Festuca altissima use to dominate in the understory (Omphalodo-Fagetum var. geogr. Saxifraga cuneifolia festucetosum altissimae). Profile No. 3 is very similar in physical and chemical characteristics to profile No. 2, only that the amounts of magnezium and potassium in the A horizon are a bit lower. However, the amount of calcium is the highest and phosphorus the lowest of all analyzed profiles. This soil type is usualy found on lower elevation and southerly exposed slopes with Sesleria autumnalis being the most dominant species in the herb layer (Omphalodo-Fagetum var. geogr. Saxifraga cuneifolia seslerietosum autumnalis). 
Higher amounts of magnesium in the A horizon of a profile No. 4 is a consequence of a bedrock, formed from the dolomitized limestone. Soil is very shallow, sceletous and is aboundantly crisscrossed by roots. Beside the profile No. 1, the horizons $\mathrm{O}_{h}$ and $\mathrm{A}$ are the most acidic. The amounts of calcium and potassium in the A horizon are the lowest of all analyzed profiles. This type of soil suits well to blueberry, Vaccinium myrtillus, a rather common chamaephyte in frigoriphilous fir-beech stands developed on higher elevation (Omphalodo-Fagetum var. geogr. Saxifraga cuneifolia saxifragetosum cuneifoliae). In profile No. 5, similarly to profile No. 4, the bedrock consists of dolomite and dolomitized limestone which is evident in higher amounts of magnezium and calcium. However, the $\mathrm{O}_{h}$ horizon is a bit more acidic, has greater amounts of calcium, magnezium, phosphorus and potassium, while the amount of organic matter and carbon are lower. The vegetation type, developed on the sampling site of soil profile No. 5, we classified as Omphalodo-Fagetum var. geogr. Calamintha grandiflora sambucetosum nigrae.

\subsection{Tipology of DinARIC FIR-BEech STANDS}

Querco-Fagetea
Fagetalia sylvaticae
Aremonio-Fagion
Omphalodo-Fagetum
var. geogr. Saxifraga cuneifolia
- rhododendretosum hirsuti Dakskobler
$\quad$ et al. 2000
- adenostyletosum glabrae subass. nov.
- saxifragetosum cuneifoliae subass. nov.
- calamagrostietosum arundinaceae sub-
ass. nov.
- festucetosum altissimae subass. nov.
- stellarietosum montanae subass. nov.
- calamagrostietosum variae subass. nov.
- seslerietosum autumnalis subass. nov.
var. geogr. Calamintha grandiflora
- sambucetosum nigrae subass. nov.
- asaretosum europei Puncer 1980 var.
$\quad$ Symphytum tuberosum var. nov.

Geographical variant Omphalodo-Fagetum var. geogr. Saxifraga cuneifolia

\section{Subassociation -rhododendretosum hirsuti Daks- kobler et al. 2000}

Ecology and phytosociology of these stands were discussed in detail by Dakskobler et al. (2000). Fir-beech stands with Hairy Alpenrose were recorded on the northern slopes of the Golaki range in northern part of the research area, and prefer thriving on organogenic soil of steep $\left(\mathrm{Me}=35^{\circ}\right)$, rocky and shady slopes at elevation between (1130-)1250-1350 m. Both Rayleigh's and chi-square tests show statistical significance for non-randomly distributed directions (Figure 6). General site characteristics and floristic composition of stands suggest the most extreme environmental conditions of all studied fir-beech lower rank syntaxa in the Trnovski gozd plateau (Figures 4-6). Due to extremly diversified relief and stoniness ( $\mathrm{Me}=60 \%)$, tree layer use to cover round $70 \%$ of the relevé area. Above all studied stands, shrub $(\mathrm{Me}=50 \%)$ and moss layers $(\mathrm{Me}=20 \%)$ achieve the highest coverage (Table 1). Species from the spruce forests (VaccinioPiceetea) achieve the highest coverage $\left(23.3 \%{ }^{653.5}\right)$ and are almost equally frequent as species of the European beech forests (Fagetalia sylvaticae: $\left.24.1 \%^{439.6}\right)$. These stands host the highest number of species of classes Mulgedio-Aconitetea $\left(12 \%^{154.2}\right)$, Asplenietea trichomanis $\left(9.8 \%{ }^{131.9}\right)$ and Erico-Pinetea (6\% ${ }^{109}$; Table 1). Fagus sylvatica dominates in the tree layer $\left(100 \%^{84}\right)$. With lower coverage there are also Abies alba $\left(100 \%^{36.8}\right)$, Acer pseudoplatanus $\left(63 \%^{12.5}\right)$ and Picea abies $\left(44 \%^{8.3}\right)$. The most frequent taxa (occuring in more than $90 \%$ relevés) in the shrub and herb layers are: Calamagrostis arundinacea $\left(100 \%{ }^{60.4}\right)$, Vaccinium myrtillus $\left(100 \%{ }^{45.8}\right)$, Rosa pendulina $\left(100 \%^{34.7}\right)$, Anemone nemorosa $\left(100 \%^{34.7}\right)$, Lonicera nigra $\left(100 \%^{31.3}\right)$, Athyrium filix-femina $\left(100 \%^{30.6}\right)$, Polygonatum verticillatum $\left(100 \%^{30.6}\right)$, Clematis alpina $\left(100 \%^{29.9}\right)$, Rubus saxatilis $\left(100 \%{ }^{28.5}\right)$, Polystichum lonchitis $\left(100 \%^{27.1}\right)$, Asplenium viride $\left(100 \%{ }^{26.4}\right)$, Maianthemum bifolium $\left(100 \%^{26.4}\right)$, Gentiana asclepiadea $\left(100 \%{ }^{25.7}\right)$, Aruncus dioicus $\left(100 \%^{25.7}\right)$, Veratrum album $\left(100 \%^{24.7}\right)$, Adenostyles glabra $\left(100 \%^{24.3}\right)$, Salix appendiculata $\left(100 \%^{24.3}\right)$, Lilium martagon $\left(100 \%{ }^{22.2}\right)$, Huperzia selago $\left(100 \%^{22.2}\right)$, Rhododendron hirsutum $\left(94 \%^{58.3}\right)$, Cardamine enneaphyllos $\left(94 \%^{30.9}\right)$, Valeriana tripteris $\left(94 \%^{29.9}\right)$, Veronica urticifolia $\left(94 \%^{29.9}\right)$, Lonicera alpigena $\left(94 \%^{28.5}\right)$, Gymnocarpium dryopteris $\left(94 \%^{25.7}\right)$ and Ranunculus platanifolius $\left(94 \%{ }^{24.3}\right)$. 


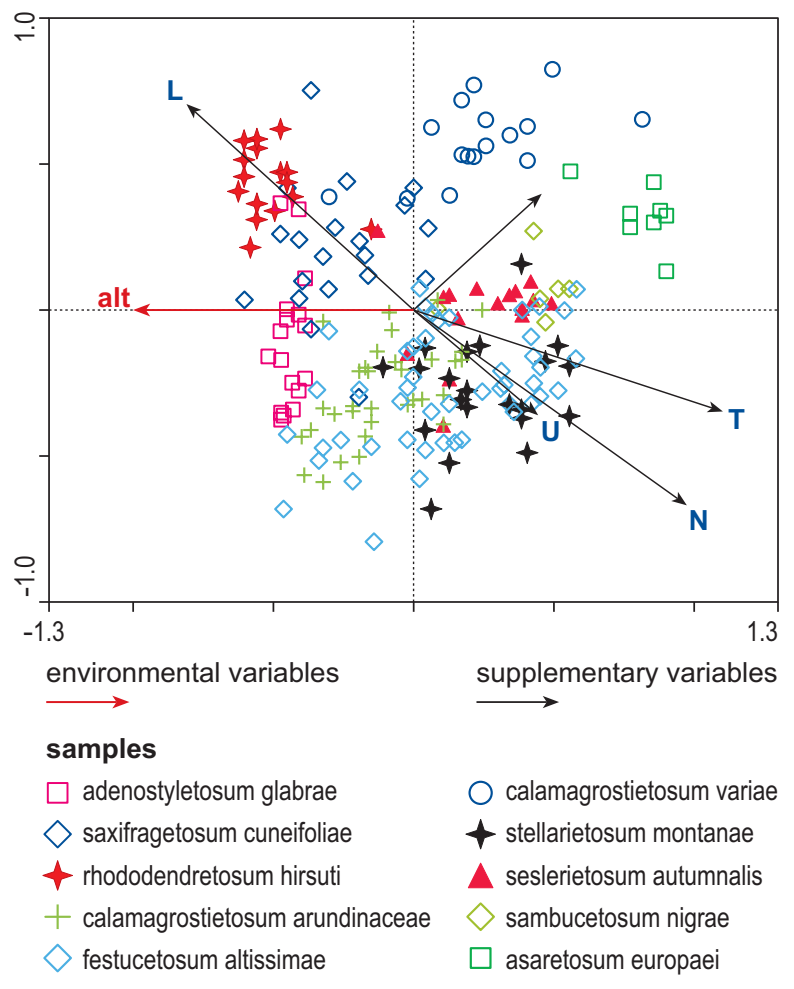

Figure 4: RDA analysis of Dinaric fir-beech stands (Omphalodo-Fagetum) in the Trnovski gozd plateau (NW Dinaric Alps), according to elevation (alt) and Pignatti's indicator values: nutrients $(\mathrm{N})$, light conditions $(\mathrm{L})$, moisture $(\mathrm{U})$, temperature (T) and soil reaction (R). Only elevation was used as an explanatory variable (F-ratio= 15.87 ; p-value 0.002 ), while other indicator values were used as supplementary variables and are passively projected. Eigenvalues $0.068,0.123,0.086$, 0.057 , cumulative percentage of variance of species data: 6.8 , 19.0, 27.6 and 33.3.

Slika 4: RDA analiza dinarskih jelovo bukovih sestojev (Omphalodo-Fagetum) v Trnovskem gozdu (severozahodni Dinaridi), glede na nadmorsko višino (alt) in Pignattijeve indikatorske vrednosti: nutrienti $(\mathrm{N})$, svetlobne razmere $(\mathrm{L})$, vlažnost rastišč $(\mathrm{U})$, temperatura $(\mathrm{T})$ in reakcija tal $(\mathrm{R})$. Za pojasnjevalno spremenljivko smo izbrali le nadmorsko višino (F-ratio= 15.87; p-value 0.002), medtem ko smo indikatorske vrednosti obravnavali kot dodatne spremenljivke in so le pasivno preslikane na diagram. Vrednosti eigenvalues: 0.068 , $0.123,0.086,0.057$, kumulativni odstotek variance vrstne sestave: $6.8,19.0,27.6$ in 33.3.

From the group of character species, Rhamnusfallax and Calamintha grandiflora are lacking, while differential species for the geographical variant are fully represented (Table 4). The subassociation -rhododendretosum hirsuti is floristically and ecologically very well defined. It also hosts the highest number of seed plants per relevé area (mean=65.3, Figure 5), while low coefficient of variation in number of seed plants per relevé
(10\%) suggests very homogenous species composition (Table 1).

According to numerical analyses, one relevé we made belongs to the subassociation -rhododendretosum, although the stand lacks majority of its differential taxa, and most probably represents a transitional stand towards the subassociation -saxifragetosum cuneifoliae:

Locality: Predmeja, Mali Golak, Paradana above Ledenica; $45.990^{\circ} \mathrm{N}, 13.848^{\circ} \mathrm{E}$; alt. $1130 \mathrm{~m}$, exp. $\mathrm{SE}$, incl. $25^{\circ}$; rocky slope, stoniness $60 \%$; 17. 5 . 2000, leg. M. Zupančič, I. Dakskobler, B. Surina.

A (80\%): Fagus sylvatica 3, Abies alba 2, Picea abies 1; B (30\%): Lonicera alpigena 2, Acer pseudoplatanus 1, Fagus sylvatica 1, Abies alba +, Daphne mezereum +, Picea abies +, Rubus idaeus +, Salix appendiculata + Sorbus aria,+ S. aucuparia + ; C (60\%): Anemone nemorosa 2, Calamagrostis arundinacea 2, Adenostyles glabra 1, Cardamine enneaphyllos 1, Mercurialis perennis 1, Polygonatum verticillatum 1, Rosa pendulina 1, Vaccinium myrtillus 1 , Oxalis acetosella + , Cardamine trifolia + , Abies alba + , Actaea spicata + , Aremonia agrimonoides + , Aruncus dioicus + , Asplenium ruta-muraria,$+ A$. trichomanes ,+ A. viride + , Athyrium filix-femina + , Carex digitata + , Clematis alpina + , Cyclamen purpurascens + , Dactylorhiza fuchsii +, Dryopteris filix-mas +, Fagus sylvatica +, Galium laevigatum +, Gentiana asclepiadea + , Hepatica nobilis +, Homogyne sylvestris,$+ \mathrm{Hu}$ perzia selago + , Lilium martagon + , Lonicera nigra ,+ L. xylosteum + , Maianthemum bifolium + , Mycelis muralis + , Omphalodes verna + , Paris quadrifolia + , Phyteuma spicatum ssp. coeruleum + , Platanthera bifolia +, Polystichum aculeatum +, P. lonchitis +, Prenanthes purpurea + , Ranunculus platanifolius + , Rubus fruticosus agg. +, R. saxatilis + , Saxifraga cuneifolia + , Solidago virgaurea + , Sorbus aria + , Valeriana tripteris +, Veratrum album, Veronica urticifolia +, Viola riviniana +; D (10\%): Ctenidium molluscum 1, Dicranum scoparium +, Isothecium alopecuroides + , Neckera crispa + , Plagiochila asplenioides + , Polytrichum formosum + , Tortella tortuosa + , Cladonia digitata + , Leptogium saturninum + , Peltigera leucophlebia + , Schistidium apocarpum + .

\section{Subassociation -adenostyletosum glabrae subass. nova (Table 5)}

These stands were recorded on the south-eastern part of the Plateau, bellow the Mt. Bukov vrh (1314 $\mathrm{m}$ a.s.l.), within the forest reserve Bukov vrh (Kordiš 1985). They are developed on moderatelly inclined to steep rocky slopes $\left(\mathrm{Me}=25^{\circ}\right)$ in 

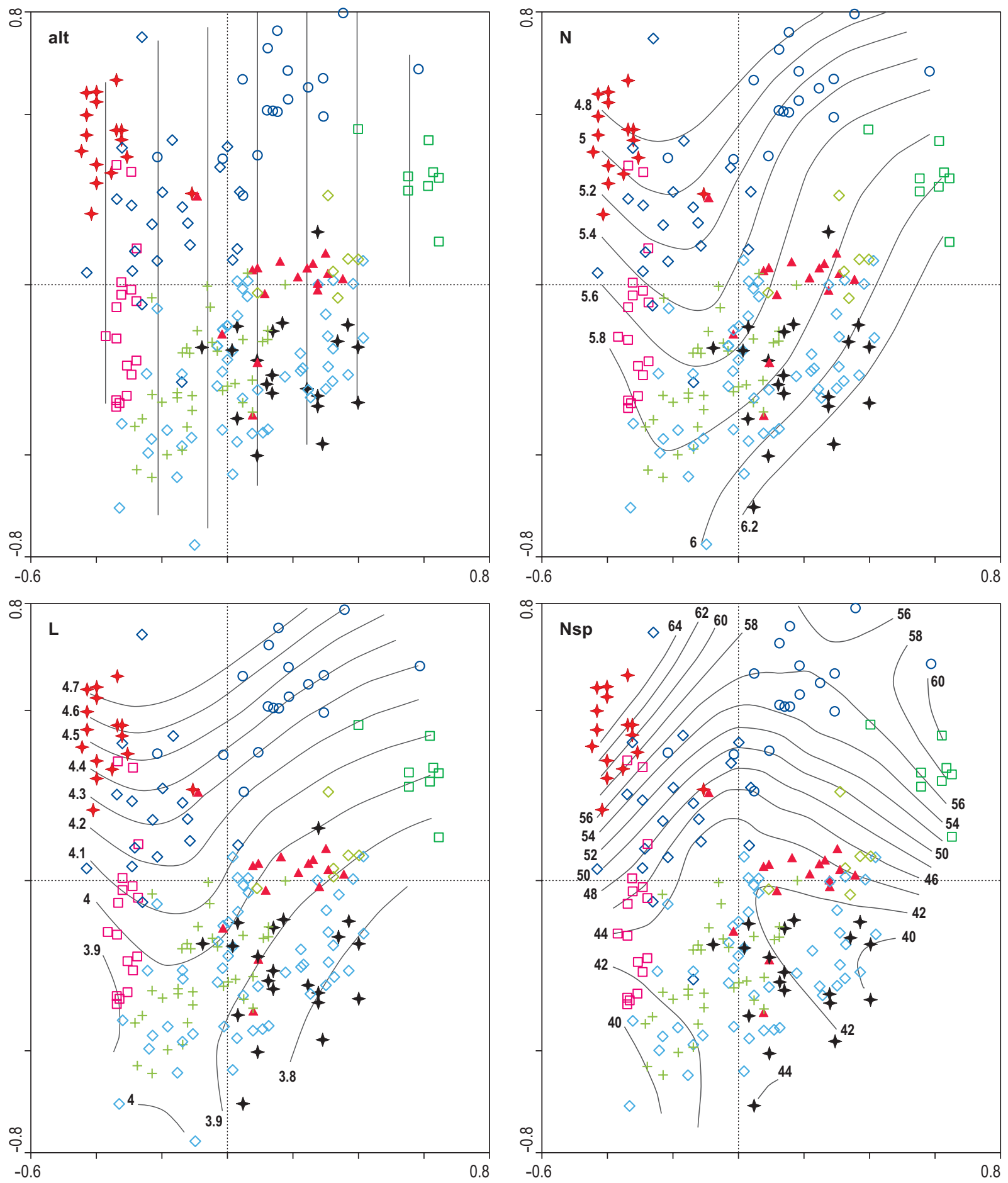

Figure 5: DCA analysis of elevation (alt), nutrients $(\mathrm{N})$, light conditions (L) and number of phanerogams per relevé (Nsp) in Dinaric fir-beech forest stands (Omphalodo-Fagetum) in the Trnovski gozd plateau (NW Dinaric Alps), according to selective phytosociological parameters and Pignatti's indicator values. Symbols are congruent with those in Fig. 4.

Slika 5: DCA analiza nadmorske višine (alt), nutrientov $(\mathrm{N})$, svetlobnih razmer $(\mathrm{L})$ ter števila praprotnic in cvetnic na popisni ploskvi (Nsp) glede na izbrane fitocenološke parametre in Pignattijeve indikatorske vrednosti v dinarskih jelovo bukovih sestojoh (Omphalodo-Fagetum) v Trnovskem gozdu (severozahodni Dinaridi). 


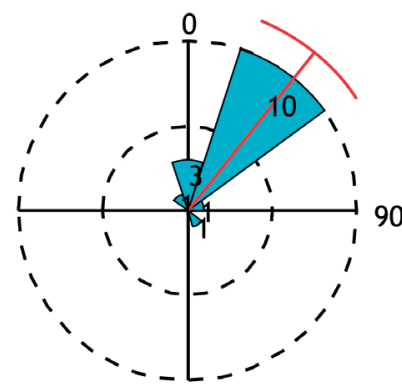

rhododendretosum

(R: $\left.p=2.8109 E-07^{*}, H^{2}=2,526 E-07^{*}\right)$

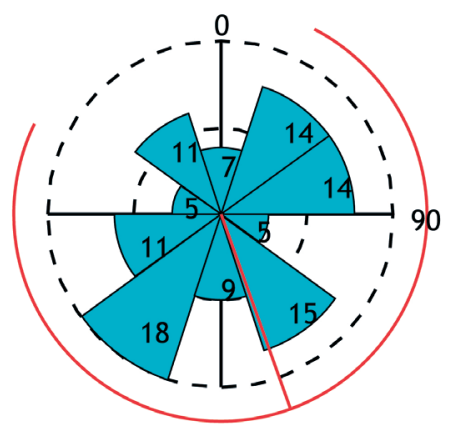

cal. arundinaceae

(R: $\left.p=0,565, H^{2}=0,113\right)$

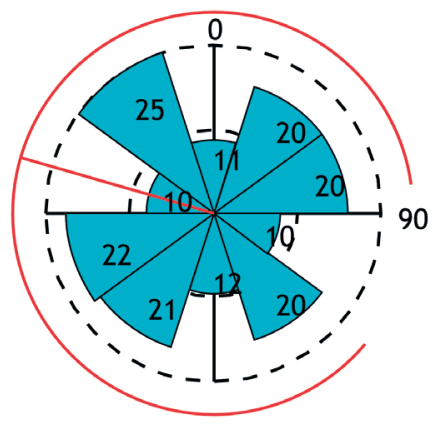

stellarietosum

(R: $p=0,781, H^{2}=0,121$ )

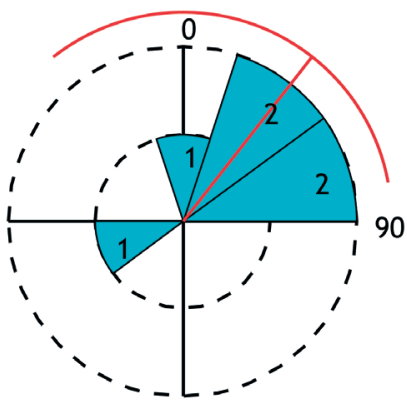

sambucetosum

(R: $p=0,154, H^{2}=0,01005^{*}$ )

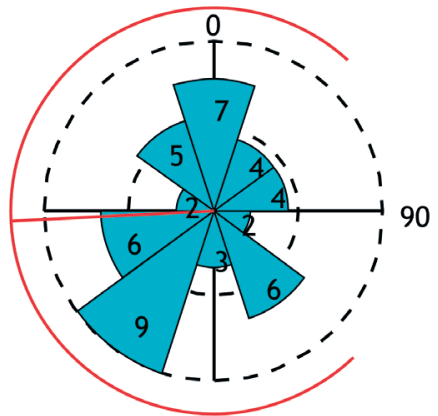

adenostyletosum

(R: $p=0,61688, H^{2}=0,4753$ )

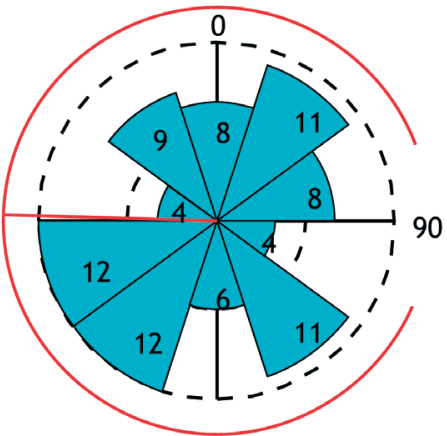

festucetosum I

(R: $p=0,858, H^{2}=0,331$ )

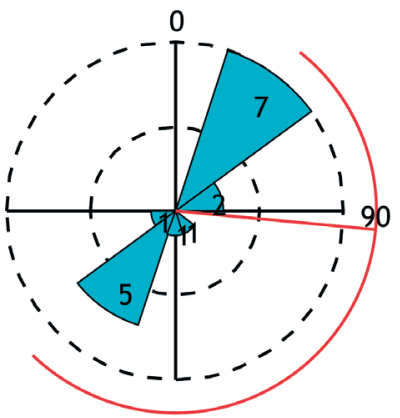

cal. variae

(R: $p=0,568, H^{2}=0,00117^{*}$ )

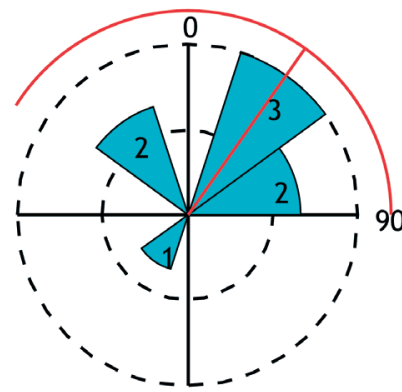

asaretosum

(R: $p=0,229, H^{2}=0,0072^{*}$ )

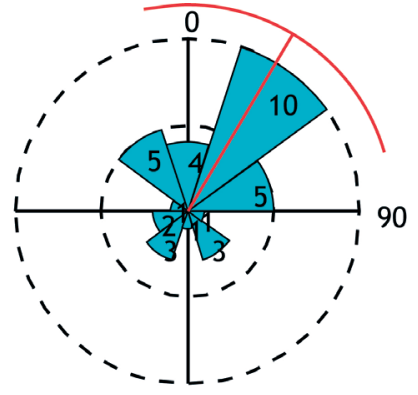

saxifragetosum

(R: $p=0,0023^{*}, H^{2}=0,00088^{*}$ )

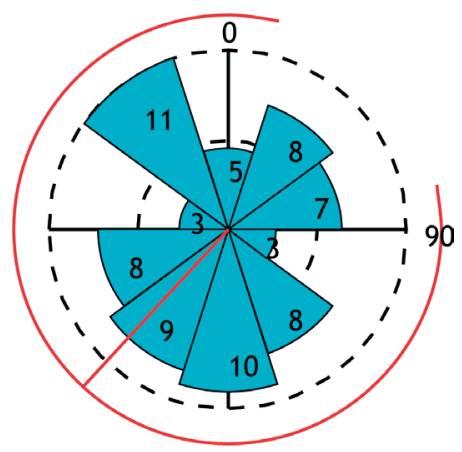

festucetosum II

(R: $p=0,691, H^{2}=0,274$ )

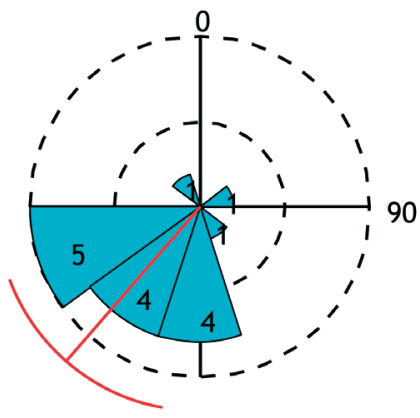

seslerietosum

(R: $p=0,0015^{*}, H^{2}=0,019^{*}$ )

Figure 6: Rose plots of exposition of different types of Dinaric fir-beech forests (OmphalodoFagetum) in the Trnovski gozd plateau (NW Dinaric Alps). Statistically significant results of Rayleigh's test (R) and chi-square tests (H2) are marked with an asterix.

Slika 6: Diagrami ekspozicije različnih tipov dinarskega jelovega bukovja (Omphalodo-Fagetum) v Trnovskem gozdu (severozahodni Dinaridi). Statistično značilne vrednosti Rayleigh-jevega (R) in hi-kvadrat testa so označene z zvezdico. 
the altimontane belt (1240-1300 m a.s.l.) on dolomites and dolomitized (rarely pure) limestones regardless of slope exposition (Figure 6, Table 2). The most common soil type is rendzina. In the tree layer, Fagus sylvatica usually prevails, while Abies alba and Acer pseudoplatanus are less frequent. Complete floristic inventory and the differential species of the subassociation (Adenostyles glabra, Veratrum album and Saxifraga rotundifolia) in particular indicate intermediate position of stands between fir-beech forest stands and the altimontane beech forest stands of the association Ranunculo platanifolii-Fagetum, developed on the summit of the Mt. Bukov. Among the character species of the association, only Cardamine trifolia occurs with higher constancy (89\%); Aremonia agrimonoides, Omphalodes verna and Rhamnus fallax occur in only $6 \%$ of releves (Tables 4 and 5). Paederota lutea and Phyteuma scheuchzeri ssp. columnae were the most frequent geographically differential taxa. In comparison to other studied syntaxa, these stands host the highest proportion of the taxa from the groups of tall herbs (Mulgedio-Aconitetea), rock crevices (Asplenietea trichomanis) and subalpine and alpine grasslands (Elyno-Seslerietea). Ecologically and floristically (biogeographically), these stands, at the upper elevational limit of the Dinaric fir-beech association (Figures 4 and 5), represent transitional forests towards altimontane beech stands at the north-westernmost part of their distribution area. Vikariant form of this subassociation from the Kočevsko region (SE Slovenia) is Omphalodo-Fagetum var. geogr. Calamintha grandiflora adenostyletosum glabrae, described by Puncer (1980).

\section{Subassociation -saxifragetosum cuneifoliae sub- ass. nova (Table 6)}

Typical stands of this syntaxon are developed on higher elevation ( $\mathrm{Me}=1200 \mathrm{~m})$ and markedly cooler sites, on rocky, shady and steep slopes (Table 2, Figures 4-6). Slope inclination was the highest of all studies syntaxa $\left(\mathrm{Me}=40^{\circ}\right.$, but up to $50^{\circ}$ ). Slopes are most frequently of northern - north-eastern exposure rendering both Rayleigh's and chi-square tests statistically significant for non-randomly distributed directions (Figure 6). The soil is predominantly composed of moder rendzina on limestone bedrock (Table 3 , profile No. 4, Figure 3). Tree layer only rarely covers $100 \%$ of the relevé area $(\mathrm{Me}=80 \%)$ due to highly diversified relief and slopes intersepted with boulders and rocks. While shrub layer is on- ly moderately $(\mathrm{Me}=20 \%)$, herb layer is rather well developed ( $\mathrm{Me}=75 \%)$ but due to highly diversified relief only rarely forms a homogenous layer. Moss layer is well developed and usualy covers about $10 \%$ of the relevé area. The most numerous taxa belong to the group of European beech forest species (Fagetalia sylvaticae, $30.6 \%$ of total species inventory, $\mathrm{I}_{\mathrm{c}}=433.3$ ), while the highest coverage of all studied syntaxa achieve taxa from the group of spruce forest species (Vaccinio-Piceetea, $23.1 \%, \mathrm{I}_{\mathrm{c}}=717.8$; Table 1). This is explained by severe ecological conditions which suite well the species adopted to moist and shady sites. To this end, these stands also host relatively high proportion of tall herbs (Mulgedio-Aconitetea, 9\%, $\mathrm{I}_{\mathrm{c}}=36.1$ ) and species of rock crevices (Asplenietea trichomanis; 7.5\%, $\mathrm{I}_{\mathrm{c}}=122.8$ ). In total, 118 taxa of ferns and seed plants were recorded for the subassociation; mean number of taxa per relevé is 51.5 (CV=12.4\%; Table 1), and the complete floristic inventory is given in Tables 4 and 6 . From the character species of the association, beside Abies alba as an edificator, only Cardamine trifolia and Ompalodes verna were relatively frequent, while Aremonia agrimonoides and Calamintha grandiflora appear only sporadically and with low coverage values. Rhamnus fallax is completely absent in selected stands. Differential species for the geographical variant are all well represented. The most frequent taxa (present in more than 90\% of relevés) in the herb layer are Asplenium viride $\left(100 \%^{28}\right)$, Gentiana asclepiadea $\left(100 \%{ }^{27.8}\right)$, Calamagrostis arundinacea $\left(95 \%{ }^{63.3}\right)$, Polygonatum verticillatum $\left(95 \%^{30.6}\right)$, Rosa pendulina $\left(95 \%^{29.4}\right)$, Clematis alpina $\left(90 \%{ }^{48.9}\right)$, Anemone nemorosa $\left(90 \%{ }^{30.6}\right)$, Prenanthes purpuera $\left(90 \%{ }^{29.4}\right)$, Calamagrostis arundinacea $\left(94 \%{ }^{69.3}\right)$, Valeriana tripteris $\left(94 \%{ }^{69.3}\right)$, Solidago virgaurea $\left(90 \%^{27.2}\right)$ and Daphne mezereum $\left(90 \%{ }^{22.8}\right)$. Floristical composition of stands of the subassociation -saxifragetosum on their upper elevational limit show a transition to Dinaric fir-beech stands with Hairy Alpenrose (Omphalodo-Fagetum var. geogr. Saxifraga cuneifolia rhododendretosum) and subalpine beech stands (Polysticho lonchitis-Fagetum var. geogr. Allium victorialis) sharing majority of the floristic inventory. This is particularly true for the subassociation -rhododendretosum (Figures 4-6), where half of the differential species for the subassociation -rhododendretosum, although with much smaller coverage values, appear in stands of the subassociation -saxifragetosum (Table 4). Another feature shared by both fir-beech syntaxa is high proportion and coverage values of species of 
the classes Vaccinio-Piceetea and Asplenietea trichomanes (Table 1). Fir-beech stands of the subass. -saxifragetosum are on their lower elevational limit in transition to fir-beech stands of the subassociations -festucetosum altissimae and -calamagrostietosum arundinaceae. As a differential species for the subassociation we selected Saxifraga cuneifolia, a typical representative of the class Vaccinio-Piceetea which achieve the highest coverage value of all studied syntaxa. Although only a progressive differential species and frequent in stands classified to other fir-beech syntaxa on higher elevation (Table 4), Saxifraga cuneifolia achieves the highest coverage and constancy in stands of the subassociation -saxifragetosum.

\section{Subassociation -calamagrostietosum arundi- naceae subass. nova (Table 7)}

Calamagrostis arundinacea is, in contrary to the Dinaric fir-beech stands of other regions in Slovenia (Omphalodo-Fagetum var. geogr. Calamintha grandiflora), the most frequent grass species in studied stands in the research area. Hence, stands where it dominates in the herb layer are one of the most widespread in the Trnovski gozd plateau, particularly in its central and western part of the research area. These stands thrive at lower elevation on plains or moderatelly inclined rocky slopes, while at higher elevation on steeper slopes $\left(\mathrm{Me}=20^{\circ}, 0-50^{\circ}\right)$ and ridges exposed to Bora between 945-1245 m (Me=1130; Figures 4-6). Although warmer slope expositions prevail, Rayleigh's and chi-square tests show no statistical significance for non-randomly distributed directions (Figure 6). RDA analyses furtherly suggest sunny (tree canopy is markedly disclosed), dryer and warmer sites and soils with pronounced lower $\mathrm{pH}$ reaction (Figures 4-6). This is congruent with the results of soil analyses (Table 3, Figure 3), where the A horizon has the lowest $\mathrm{pH}$ reaction (4.2) and contains the lowest amount of calcium, magnesium, potassium, organic matter, nitrogen, sand and silt, but the highest amount of clay of all analyzed soil profiles. Fagus sylvatica and Abies alba dominate in tree layer, covering 70$100 \%$ of a relevé area (Table 2). Due to disclosed canopy (see light conditions in Figures 4 and 5), Sorbus aria use to penetrate frequently out of the shrub layer. Occasionally, and mainly due to consequences of forest management, Picea abies occurs abundantly. Shrub layer is poorly developed ( $\mathrm{Me}=20 \%)$ and mainly constituted of beech, fir, spruce and maple offsprings. One of the charac- teristics of these stands is low species diversity per relevé in the herb layer (mean=42.9, 32-58; Figure 5). This is most probably due to dense tussocks formed by Calamagrostis arundinacea, disabling successful germination and rejuvenation of other seed plants. However, relativelly low coefficient of variation (13.7\%) suggests rather homogenous species composition of stands. Most of the species inventory belongs to European beech forests group of taxa (Fagetalia sylvaticae), representing $35.9 \%\left(\mathrm{I}_{\mathrm{c}}=561\right)$ of the total inventory of the subassociation. Acidophilous taxa of the spruce forests (Vaccinio-Piceetea) are frequent as well $\left(20.4 \%^{466.7}\right)$. Tall herbs (Mulgedio-Aconitetea) and illyricoid species (Aremonio-Fagion) represent $7.7 \%\left(I_{c}=10.8\right)$ and $7 \%\left(I_{c}=108.5\right)$, respectivelly. The most frequent and abundant taxa are Dryopteris filix-mas $\left(100 \%^{27.5}\right)$, Senecio ovatus $\left(100 \%^{26.5}\right), M y$ celis muralis $\left(100 \%{ }^{25.8}\right)$, Calamagrostis arundinacea $\left(94 \%^{69.3}\right)$, Oxalis acetosella $\left(94 \%^{50.3}\right)$, Cardamine trifolia $\left(94 \%^{35.6}\right)$, Adenostyles glabra $\left(94 \%^{35.6}\right)$, Prenanthes purpurea $\left(94 \%^{30.1}\right)$, Adenostyles glabra $\left(94 \%^{28.4}\right)$, Athyrium filix-femina $\left(94 \%^{28.1}\right)$, Rubus idaeus $\left(94 \%^{25.2}\right)$ and Galeobdolon flavidum $\left(94 \%^{24.2}\right)$. Continuous transition to stands of the subassociation -festucetosum altissimae (Figures 4 and 5), specially on higher elevation, cooler and moister sites, are frequent and indicated by high coverage of Festuca altissima $\left(68 \%^{22.9}\right)$, rendering the differentiation between the two syntaxa difficult (Figure 7; see the discussion further below). In moss layer, only 17 taxa were recorded where only Ctenidium molluscum $\left(76 \%^{34}\right)$, Cladonia coniocraea $\left(56 \%^{12.7}\right)$ and C. pyxidata $\left(53 \%^{11.8}\right)$ occur in more than $50 \%$ of the relevés.

From the character species of the association, Cardamine trifolia $\left(94 \%^{35}\right)$ and Aremonia agrimonoides $\left(71 \%^{17.3}\right)$ are frequent, while both Calamintha grandiflora and Omphalodes verna occur in $6 \%$ of the relevés. As a differential species for the subassociation -calamagrostietosum arundinaceae we chose Calamagrostis arundinacea, a taxon already mentioned as a local differential species for studied stands by Puncer (1979). Calamagrostis arundinacea thrives from montane to subalpine belt, frequently on non-calcareous bedrock or sandstone, moderatelly acid to acid humus, on shallow or deep soils (Table 3). In Slovenia it is frequent above all in coniferous, rarely in deciduous forests (Zupančič 1980). Due to ecological preferences and high constancy in spruce and acidophilous fir-, fir-beech- and pine forests across the Europe, phytosociologists consider Calama- 
grostis arundinacea as characteristic species for the class Vaccinio-Piceetea (Zupančič 1980).

Being missleaded by the taxonomic issues regarding the genus Calamagrostis in the studied area, M. Wraber (1953) treated stands of the subassociation -calamagrostietosum arundinaceae as Abieti-Fagetum calamagrostidetosum variae nom. inv., a mistake repeated by later phytosociologists who studied the phytosociology of fir-beech stands in the Trnovski gozd plateau (Marinček et al. 1977, Urbančič et al. 1979), while on the northeastern part of the plateau, selective stands were not recorded (Čampa 1978). G. varia occurs more frequently only at the north-eastern part of the research area, while $C$. arundinacea generally prevails across the whole plateau. Based mainly on physiognomy of stands, Wraber $(1953,1959)$ differentiated two elevational variants. However, in our analyses and according to floristic inventories, we couldn't confirm his synsystematic treatment. This may well be due to the high impact of forest management on floristic inventory and physiognomy of stands, since after woodcutting, causing the overexposition of undergrowth, Calamagrostis arundinacea quickly started to dominate in the herb layer. On lower elevation, dryer and warmer sites, stands of the subassociation -calamagrostietosum arundinaceae are in contact with stands of the subassociation -seslerietosum autumnalis.

\section{Subassociation -festucetosum altissimae subass. nova (Tables 8 \& 9)}

These stands are the most frequent and along with stands of the subassociation -calamagrostietosum arundinaceae represent the central type of firbeech forests in the study area, occuring between 790 (on northerly exposed slopes) and $1275 \mathrm{~m}$ a.s.l. (sunny and warmer sites) in elevationally the widest belt of all studied stands (Table 2) and all expositions (both Rayleigh's and chi-square tests show no statistical significance for non-randomly distributed directions, Figures 4-6). Although the percentage of stoniness per relevé may vary a lot $(0-80 \%)$, most typical stands are developed on rocky and steep slopes with rocks and boulders arranged in cascades. Stands are scatered through all the research area but never occur on large and homogenous areas. Soils are shallow and organogenic, brown rendzines prevail (Figure 3, Table 3). In the tree layer Fagus sylvatica and Abies alba, occasionally intermixed with Picea abies, dominate. In severely perturbated stands by forest management, fir may be com- pletely replaced by spruce. Acer pseudoplatanus and Sorbus aucuparia are less frequent. Shrub layer use to cover round $10 \%$ of relevé area, and beside the beech the most frequent taxa are $R u$ bus idaeus, Daphne mezereum, Sambucus nigra, Lonicera nigra and Rosa pendulina. In typical stands, Festuca altissima prevails in herb layer. On sunny sites with lower stoniness and slope inclination, more acidic and nutrients impoverished soils, Calamagrostis arundinacea may co-dominate, thus rendering typological delimitation of respective sintaxa (namelly, -festucetosum altissimae and -calamagrostietosum arundinaceae) difficult (Figures 4-6). Other frequent, moderately acidophilic species are Luzula luzuloides and Oxalis acetosella. In general, species of the class VaccinioPiceetea are very frequent and abundant, indicating cooler and moister site conditions (Table 1, Figure 4). European beech forests species represent core group of inventory (up to $38 \%$ of total species inventory): Dryopteris filix-mas $\left(100 \%{ }^{23-32}\right)$, Paris quadrifolia $\left(92 \%^{11.5-22.2}\right)$ and Galeobdolon flavidum (80-85\% ${ }^{21.4-22.2}$ ) occur in more then $80 \%$ of relevés. Illyricoid taxa (Aremonio-Fagion) are less frequent, representing round $6 \%$ of a total species inventory. Cardamine trifolia and Aremonia agrimonoides are, beside the edifier Abies alba, the only character species with higher constancy (Tables 1 and 4); Rhamnus fallax occurs sporadically and with low coverage, while Omphalodes verna and Calamintha grandiflora are completely absent. Moss layer may cover high percentage of the relevé area (up to $60 \%$ ), specially on sites with high stoniness, with Neckera crispa, Dicarnum scoparium and Ctenidium molluscum being the most frequent moss taxa. All in all, 131 (Table 9 - typical variant, Puncer's relevés) and 135 (Table 8 - variants with Calamagrostis arundinacea, Lamium orvala and Picea abies) fern and seed plants were recorded, with round 40 species per relevé (24-55).

As a differential species for the subassociation we selected Festuca altissima, occuring in tussocks and contributing most to the physiognomy of typical stands. They were typologically segregated already by M. Wraber $(1953,1959)$, Marinček et al. (1977), Čampa (1978) and Urbančič et al. (1979), but without selection of differential species. Puncer (1979) proposed Festuca altissima, Orthilia secunda and Dicranum scoparium as differential species based on the results of his studies from the Kočevski rog area (Puncer et al. 1974, Puncer 1980). However, Orthilia secunda occurs in our stands only moderatelly, while Dicranum 

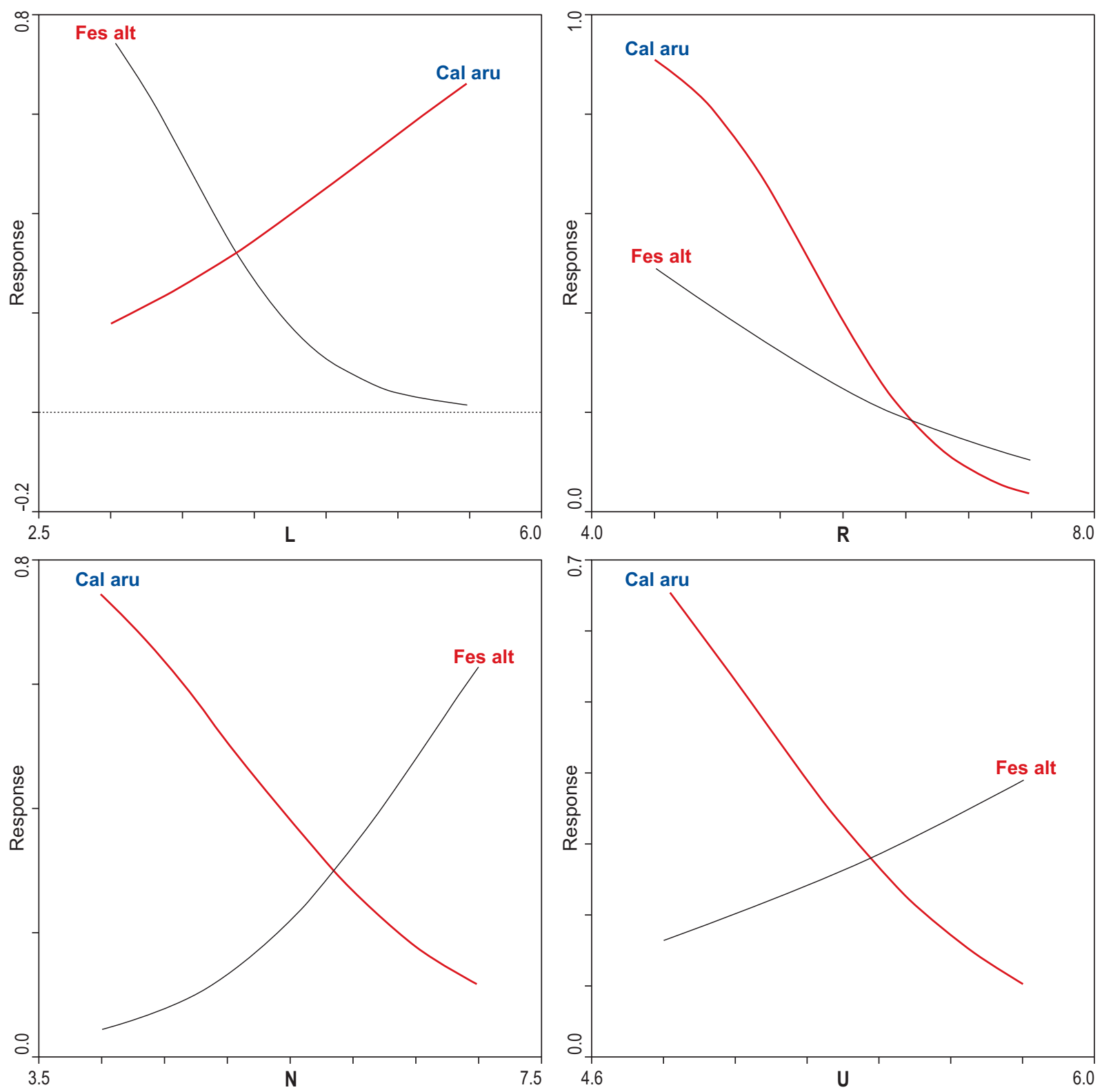

Figure 7: Species response curves for Calamagrostis arundinacea and Festuca altissima in Dinaric fir-beech stands (OmphalodoFagetum) in the Trnovski gozd plateau (NW Dinaric Alps), according to selective Pignatti's indicator values; light conditions $(\mathrm{L})$, soil reaction $(\mathrm{R})$, nutrients $(\mathrm{N})$, moisture $(\mathrm{U})$; response model type: generalized linear model; degree: linear; distribution: binomial.

Slika 7: Krivulje odzivnosti vrst Calamagrostis arundinacea in Festuca altissima glede na Pignattijeve indikatorske vrednosti v sestojih dinarskega jelovega bukovja (Omphalodo-Fagetum) v Trnovskem gozdu (severozahodni Dinaridi); svetlobne razmere (L), reakcija tal $(\mathrm{R})$, nutrienti $(\mathrm{N})$, vlaga $(\mathrm{U})$; tip modela odzivnosti: generaliziran linearni model; stopnja: linearna; porazdelitev: binomska.

scoparium occurs in stands of all studied syntaxa with different frequences and coverage values (Table 4). Therefore we did not select them as differential species for the subassociation.

Floristic composition and structure of stands of the subassociation -festucetosum altissimae are presented in Tables 8 and 9, based on the results of cluster and ordination analyses. In stands from the Table 8 we recognized three variants furtherly supported by the results of RDA analysis (Figure 8). Stands of the variant Calamagrostis arundinacea (differential species for the variant is 
Figure 8: RDA analysis of Dinaric fir-beech stands (Omphalodo-Fagetum) in the Trnovski gozd plateau (NW Dinaric Alps), of three subassociations: A - seslerietosum autumnalis, B - stellarietosum montanae, $\mathrm{C}$-festucetosum altissimae, according to elevation (alt) and Pignatti's indicator values: nutrients $(\mathrm{N})$, temperature $(\mathrm{T})$, soil reaction $(\mathrm{R})$, moisture (U), light conditions (L). Only elevation was used as an explanatory variable, while other indicator values were used as supplementary variables and are passively projected (A: alt $-\mathrm{F}=2,582, \mathrm{p}=0,004 ; \mathrm{B}$ : alt $-\mathrm{F}=5,568, \mathrm{p}=0,002$; $\mathrm{C}$ : alt $-\mathrm{F}=2,614, \mathrm{p}=0,002)$.

Slika 8: RDA analiza sestojev treh subasociacij (A - seslerietosum autumnalis; $\mathrm{B}$ - stellarietosum montanae in $\mathrm{C}$ festucetosum altissimae) dinarskih jelovo bukovih gozdov (Omphalodo-Fagetum) v Trnovskem gozdu (severozahodni Dinaridi), glede na nadmorsko višino (alt) in Pignattijeve indikatorske vrednosti: nutrienti $(\mathrm{N})$, temperatura $(\mathrm{T})$, reakcija tal (R), vlažnost rastišč (U) in svetlobne razmere (L). Za pojasnjevalno variablo smo izbrali le nadmorsko višino (A: alt $-\mathrm{F}=2,582, \mathrm{p}=0,004 ; \mathrm{B}$ : alt $-\mathrm{F}=5,568, \mathrm{p}=0,002$; $\mathrm{C}$ : alt $-\mathrm{F}=2,614, \mathrm{p}=0,002)$, medtem ko smo indikatorske vrednosti obravnavali kot dodatne variable in so le pasivno preslikane na diagram.

Calamagrostis arundinacea) occur on sunny slopes and soils low on nutrients (Figure 7). Stands of the variant Lamium orvala (differential species for the variant are Lamium orvala, Cardamine bulbifera and $C$. impatiens) represent the most mesophilous type of the subassociation, occuring on shady, moist sites and on deeper soils rich in nutrients. Stands of the variant Picea abies (differential species for the variant are Picea abies, Saxifraga rotundifolia and $S$. cuneifolia) prefer cooler and shady sites and are usually developed on higher elevation and shallow soils. Table 9 consists almost exclusivelly of the unpublished relevés of Puncer and represents floristically impoverished stands of Dinaric fir-beech forests in the research area. On lower elevation and sunny sites, stands of the subassociation -festucetosum altissimae are in contact with stands of the subassociation -seslerietosum autumnalis, while on higher elevation and more acidic soils with stands of the subassociation -calamagrostietosum arundinaceae (Figures 3-5, 7).

\section{Subassociation -stellarietosum montanae subass. nova (Table 10)}

Abundance and high coverage of ferns, tall herbs and other plants indicating high soil and air moisture as well as nutrient rich soils, are main characteristics of stands of the subassociation stellarietosum (Figures 4-6), ecologically one of the best circumscribed lower syntaxa of fir-beech for-
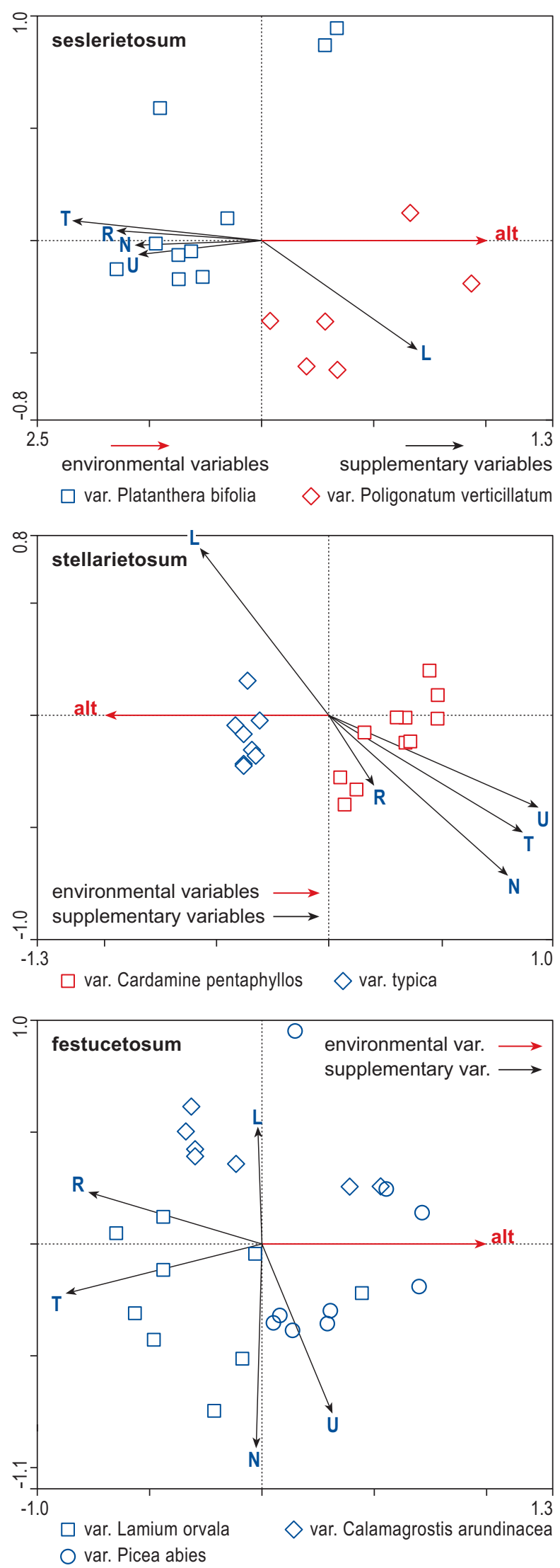
ests. These stands usualy thrive at the bottom and on flanks of small dolines, in trenches, on foothills and lower edges of larger dolines, plains and slopes between $800-1100 \mathrm{~m}$ (Me=970 m; Table 2). The most important ecological factor to shape such a specific floristic combination seem to be soil properties (Figs. 4 and 5). Median coverage of tree layer is $70 \%$, but may vary a lot (50-100\%). Fagus sylvatica dominates, while Abies alba and Acer pseudoplatanus are equally represented. Shrub layer is usualy well developed (Me=30\%). The most frequent and abundant taxa are Fagus sylvatica and Acer pseudoplatanus. One of the most distinct feature of typical stands of the subassociation -stellarietosum is abundantly developed herb layer, most frequently completely covering the site. Coverage of moss layer is very much dependent on coverage of stoniness and ranges from 1-50\% of a relevé area (Table 2). European beech forests species (Fagetalia sylvaticae) completely dominate in the floristic inventory and also achieve very high coverage values in studied stands $\left(41.3 \%^{862.4}\right)$. Only $12.9 \%$ of taxa with low coverage values belong to the group of spruce forests species (VaccinioPiceetea), which is the lowest percentage and coverage of all identified syntaxa in our survey. Tall herbs (Mulgedio-Aconitetea), while prefering moist and nutrient rich soils, achieve relatively high coverage values and represent $9.7 \%$ of species inventory in stands. In total, 137 species of ferns and seed plants were recorded. Mean number of seed plants per relevé is 45.4 and may vary from 35-64 (CV=16.1\%). Further details are given in Table 2 . All association's character species are represented with decent coverage. On the other hand, only one (Saxifraga cuneifolia) out of five differential taxa for the geographical variant is recorded in studied stands. The most frequent (occuring in more than $90 \%$ of the relevés) and abundant taxa in the herb layer are Dryopteris filix-mas $\left(100 \%{ }^{41.3}\right)$, Athyrium filix-femina $\left(100 \%{ }^{40.7}\right)$, Paris quadrifolia $\left(100 \%^{24.3}\right)$, Cardamine bulbifera $\left(95 \%^{28.6}\right)$, Stellaria montana $\left(90 \%^{39.2}\right)$, Festuca altissima (90\% $\left.{ }^{39.2}\right)$, Cardamine enneaphyllos $\left(90 \%^{31.7}\right)$, Urtica dioica $\left(90 \%{ }^{30.7}\right)$, Senecio ovatus $\left(90 \%{ }^{28.6}\right)$ and Calamagrostis arundinacea (90\% ${ }^{27.5}$; Tables 4 and 10). Differential species for the subassociation we selected from the order Fagetalia sylvaticae: Stellaria montana $\left(90 \%{ }^{39.2}\right)$, Impatiens noli-tangere $\left(81 \%^{32.8}\right)$, Adoxa moschatellina $\left(76 \%^{20.1}\right)$, Arum maculatum $\left(67 \%{ }^{15.9}\right)$, Lunaria rediviva $\left(57 \%^{27}\right)$ and Circaea lutetiana $\left(52 \%^{11.6}\right)$. While achieving high coverage and being frequent in stands of the subassociation (Table 4), they are also rather good indicators of fresh and nutrient rich, neutral to basiphilous soils in forests from lowlands to altimontane zone.

Based on numerical analyses of floristic composition of stands and environmental variables, two types of stands within the subassociation were distinguished (Figure 8). The first group of stands (var. typicum, rel. 1-13 in Table 10) are developed at the bottom and on flanks of small dolines. A representative soil profile (results not shown and discussed in earlier chapter) was more than $2 \mathrm{~m}$ deep and represented biologically very active colluvial soils with plenty of stoniness and organic matter in different stages of decomposition. Rocks and boulders frequently cover the soil surface. Floristic composition of stands suggests neutral to slightly basiphilous and nutrient rich soils, lower light and temperature conditions. Previously performed field measurements of temperature and moisture of the air in similar stands (e.g., Omphalodo-Fagetum var. geogr. Calamintha grandiflora aceretosum pseudoplatani) during the growing season suggested lower air temperature at the bottom of the dolines in comparisson to the one on the flanks, while air moisture is usualy higher at the bottom of the dolines during the growing season (Puncer 1980). Since such a specific microclimatic conditions occur almost exclusively in small dolines, studied stands are conditioned also by specific soil properties, although frequently occuring, are never developed on a large scale. Sites are usualy plane or only slightly inclined (max. up to $20^{\circ}$ ). Hence, Rayleigh's and chi-square tests show no statistical significance for non-randomly distributed directions (Figure 9). Differential species of the subassociation are very frequent and achieve high coverage values. Relevés 13-21 in Table 10, in contrast, represent stands developed on rocky slopes (median value of stoniness is round $50 \%$, max. $70 \%$ ), inclined up to $30^{\circ}$ where north-western expositions prevail. In contrast to stands of the var. typicum, both Rayleigh's and chi-square tests are statistically significant for non-randomly distributed directions (Figure 9). These stands are developed on slopes and prefer warmer sites, higher soil reactions (Figure 8) and amounts of stoniness. Differential species of the subassociation are still well represented, while their coverage is lower. Therefore, we segregated these stands into a new variant Cardamine pentaphyllos, and as differential species for the variant we chose Cardamine pentaphyllos and Mercurialis perennis. (Figure 9) 


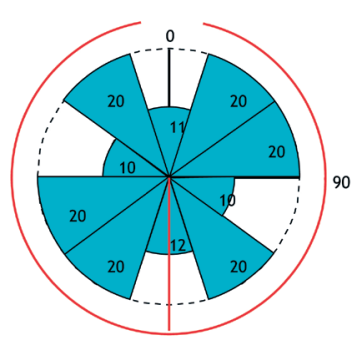

typicum

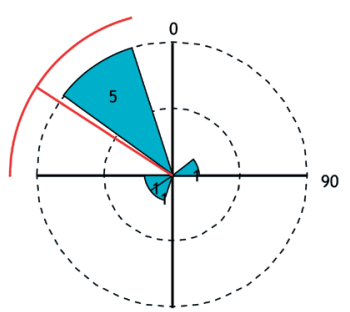

Cardamine pentaphillos (R: $p=0,033^{*}, H^{2}=0,012^{*}$ )
(R: $\left.p=0,9939, H^{2}=0,1407\right)$

Figure 9: Rose plots of exposition of Dinaric fir-beech forests (Omphalodo-Fagetum var. geogr. Saxifraga cuneifolia stellarietosum montanae var. typica and var. Cardamine pentaphyllos) in the Trnovski gozd plateau (NW Dinaric Alps). Statistically significant results of Rayleigh's test (R) and chi-square tests (H2) are marked with an asterix.

Slika 9: Diagrami ekspozicije dinarskega jelovega bukovja s kijevolistnim kamnokrečem (Omphalodo-Fagetum var. geogr. Saxifraga cuneifolia stellarietosum montanae var. typica in var. Cardamine pentaphyllos) v Trnovskem gozdu (severozahodni Dinaridi). Statistično značilne vrednosti Rayleigh-jevega (R) in hi-kvadrat testa so označene z zvezdico.

\section{Subassociation -calamagrostietosum variae sub- ass. nova (Table 11)}

These stands thrive on the Idrian (eastern) part of the Trnovski gozd plateau: at the headwaters of Idrijca river above the Bedrova grapa gorge, above the valley of Belca (Črna draga), under the Zeleni rob ridge above the Ipavšek valley in eastern part of Govci, under the Jelenk and on margines of the Vojsko plateau above the Kanomlja valley. Majority of relevés were made between $800-1000 \mathrm{~m}$ a.s.l. (Table 2), on very steep $\left(\mathrm{Me}=35^{\circ}\right)$, stony and shady slopes (Figure 6) on dolomites and rendzines. Although this is another type of transitional Dinaric fir-beech forest stands towards pre-alpine fir-beech stands of the association Homogyno sylvestris-Fagetum, character species of the association, as well as differential species of the geographical variant, are well represented (Table 4). Abies alba occurs in all layers, but is rather rare in a tree layer or even absent. Floristic inventory of stands of this subassociation is characterized by comparativelly lower proportion of spruce forests taxa (VaccinioPiceetea), and relatively high proportion of basiphytic taxa from pine forests (Erico-Pinetea), rock crevices (Asplenietea trichomanis) and subalpine and alpine grasslands (Elyno-Seslerietea), as a consequence of extreme environmental conditions and dolomite bedrock in particular
(Table 2). Differential species for the subassociation -calamagrostietosum variae are Calamagrostis varia, Carex alba, Polygonatum multiflorum, Rhamnus fallax, Helleborus niger and Buphthalmum salicifolium, rather common taxa from the basiphytic pine forests.

Subassociation -seslerietosum autumnalis subass. nova (Table 12)

On lower elevation between 800-1120 m (Figures 4 and 5, Table 2), sunny and rocky slopes (Figure 6; both Rayleigh's and chi-square test show high significance for non-random distribution of slope exposition), Sesleria autumnalis $\left(100 \%^{77.1}\right)$ completely prevails in the herb layer in fir-beech forests. These stands represent the most thermophilous fir-beech stands and are ecologically and floristically (CV=11.6\%) very well circumscribed. They are continuously distributed at the western and southern parts of the plateau where an influence of the submediterranean climate is still present. On lower elevation they are developed on summits or ridges, while on higher elevation use to cover steeper slopes. Shallow and skeletous rendzina is the most frequent soil type in these sites and is developed on limestone or dolomitized limestone (Table 3, Figure 3).

In lower and upper tree layer Fagus sylvatica $\left(100 \%^{72.9}\right)$ prevails over Abies alba (100\% $\left.{ }^{65.3}\right)$. Acer pseudoplatanus and Sorbus aria (both 6\% ${ }^{1.4}$ ) only rarely penetrate into the lower tree layer. Tree canopy use to be almost completely closed (Me=90\%). Shrub layer consists of Fagus sylvatica $\left(100 \%^{37.5}\right)$, Abies alba $\left(56 \%{ }^{13.2}\right)$, Acer pseudoplatanus $\left(38 \%^{8.3}\right)$ and Sorbus aria $\left(25 \%{ }^{5.6}\right)$ is only modestly developed, covering round $10 \%$ of the relevé's area and together with the high coverage of Sesleria autumnalis in the herb layer make these stands appear picturesque. On lower elevation Fraxinus ornus, Lonicera xylosteum (both 25\% ${ }^{5.6}$ ) and Tilia platyphyllos (both $19 \%{ }^{4.2}$ ) occur relativelly frequently, while on higher elevation more frigoriphilous and mesophilous shrubs, e.g., Rosa pendulina $\left(56 \%^{14.6}\right)$, Sambucus nigra $\left(44 \%^{9.7}\right)$ and $S$. racemosa (both $13 \%{ }^{12.5}$ ) use to prevail in the shrub layer. In typical stands, Sesleria autumnalis in dense tussocks completely domintates in herb layer. Other species present in more than $80 \%$ of relevés are Solidago virgaurea $\left(100 \%{ }^{25}\right)$, Mycelis muralis $\left(100^{22.2}\right)$, Cardamine trifolia $\left(94 \%^{24.3}\right)$, Adenostyles glabra $\left(94 \%^{24.3}\right)$, Senecio ovatus $\left(95 \%{ }^{23.6}\right)$, Dryopteris filix-mas, Galeobdolon flavidum (both $\left.94 \%^{20.8}\right)$, Mercurialis perennis, Cardamine ennea- 
phyllos (both $88 \%{ }^{32.6}$ ), Calamagrostis arundinacea $\left(88 \%^{27.8}\right)$, Maianthemum bifolium $\left(88 \%^{27.7}\right)$, Veronica urticifolia $\left(83 \%{ }^{15.3}\right)$, Oxalis acetosella $\left(81 \%^{26.4}\right)$, Anemone nemorosa $\left(81 \%^{24.3}\right)$, Galium odoratum $\left(81 \%^{20.8}\right)$, Lathyrus vernus ssp. vernus $\left(81 \%^{20.1}\right)$, Aremonia agrimonoides $\left(81 \%^{18.1}\right)$, Lamium orvala and Prenanthes purpurea (both 81\% ${ }^{18.1}$ ). Moss layer use to cover only smaller areas of relevés $(\mathrm{Me}=10 \%$, $1-30 \%)$ and are more frequent and abundant on rocky and stony sites. The most common moss taxa are Ctenidium molluscum $\left(88 \%^{37.5}\right)$ and Neckera crispa $\left(81 \%^{27.8}\right)$. Cardamine trifolia and Aremonia agrimonoides are the only character species of the association with high constancy and coverage value; Rhamnus fallax $\left(13 \%^{2.8}\right)$, occurs more rarely, while Omphalodes verna and Calamintha grandiflo$r a$ are absent. On the other hand, other illyricoid taxa (Aremonio-Fagion) represent 9.3\% $\left(\mathrm{I}_{\mathrm{c}}=134.7\right)$ of the total species inventory which is one of the highest proportion of all studied syntaxa. European beech forest species (Fagetalia sylvaticae) are the most frequent and occur with highest coverage $\left(33.5 \%{ }^{489.6}\right)$, followed by spruce forests species (Vaccinio-Piceetea, 20.3\% ${ }^{286.1}$ ). Characteristically for stands of the subassociation -seslerietosum autumnalis is that thermophilous species of the order Quercetalia pubescentis are most aboundant of all studied syntaxa $\left(6.8 \%^{104.2}\right)$. For the differential species of the subassociation -seslerietosum autumnalis we chose Sesleria autumnalis (100\% $\left.{ }^{77.1}\right)$, Lathyrus vernus ssp. vernus $\left(81 \%^{20.1}\right)$ and ssp. flaccidus $\left(50 \%{ }^{12.5}\right)$. While none of them being completely exclusive, they achieve the highest frequency and coverage in stands of the subassociation -seslerietosum autumnalis. In these stands, the physiognomy of the herb layer (and the shrub layer in part) is defined by dense carpets formed by Sesleria autumnalis, a particularly thermophylous, submediterranean-illyricoid species distributed on the western part of the Balkan peninsula from Slovenia to Macedonia and Albania with a discjunction on the Apennines. Its synsistematic characteristics and chorology were dealt in detail by Dakskobler (1991). It shows high fidelity to studied stands, occuring in stands of only two other subassociation: -saxifragetosum cuneifoliae $\left(10 \%^{5}\right)$ and -festucetosum altissimae $\left(4-7 \%^{0.9-2.9}\right)$, but with low frequency and coverage values (Table 4). Of the differential species for the geographical variant only Paederota lutea is missing.

Based on the floristic composition (Tables 1, 4 and 12), site ecology, phytosociological param- eters (Table 2) and results of the cluster and RDA analyses (Figure 8), two elevational variants were identified: var. Platanthera bifolia (differential species for the variant are Platanthera bifolia, Fraxinus ornus and Lonicera xylosteum) and var. Polygonatum verticillatum (differential species for the variant are Polygonatum verticillatum, Huperzia selago, Rosa pendulina and Anthriscus fumarioides). Stands of the variant Platanthera bifolia occur on lower elevation, warmer sites and nutrient rich soils, while stands of the variant Polygonatum verticillatum are developed on higher elevation, generally cooler sites with high coverage of stoniness, and on more acidic soils.

Complete floristic inventory of stands of the subassociation -seslerietosum represents only 118 taxa of phanerogams and 22 taxa of mosses and lichens. This might be due to high coverage and dense tussocks of Sesleria autumnalis, completely dominating in the understory. The median number of phanerogams per relevé is $41.9(35-51)$ with low coefficient of variation $(\mathrm{CV}=11.6 \%)$ indicating rather homogenous and floristically well defined stands, typologically recognized already by earlier phytosociologists (e.g., Wraber 1953: Abieti-Fagetum seslerietosum autumnalis; Wraber 1959, Urbančič et al. 1979: Abieti-Fagetum dinaricum seslerietosum autumnalis; Marinček et al. 1977, Puncer 1979: Abieti-Fagetum praealpino dinaricum seslerietosum autumnalis).

On lower elevation, fir-beech stands of the subassociation -seslerietosum are in contact with beech stands of the association Seslerio autumnalis-Fagetum var. geogr. Anemone trifolia, while on its upper elevational limits with fir-beech stands of the subassociations -calamagrostietosum arundinaceae (warmer sites, on more acidic soils) and -festucetosum altissimae (cooler and moister sites). Floristical and ecological comparissons between the syntaxa Seslerio autumnalis-Fagetum and Omphalodo-Fagetum seslerietosum autumnalis were already performed by Dakskobler (1997). He found no ubrupt changes in floristic composition between the stands of the two syntaxa, but rather gradual transitions of stands in the contact zones. However, stands of the association Seslerio-Fagetum host considerably higher number of thermophilous taxa from the order Quercetalia pubescentis, thus thriving on warmer sites and lower elevation in comparisson to stands of the subassociation Omphalodo-Fagetum seslerietosum autumnalis (Dakskobler 1997). 
Geographical variant Omphalodo-Fagetum var. geogr. Calamintha grandiflora

\section{Subassociation -sambucetosum nigrae subass. nova (Table 13)}

One of the most mesophilous and homogenous fir-beech stands are developed on lower elevation $(\mathrm{Me}=850 \mathrm{~m}, 800-1000 \mathrm{~m}$, Table 2$)$ of northeastern flanks of the plateau on slopes with low amount of stoniness (Figures 3-5). Stands prefer northerly exposed sites (Figure 6), Chi-square test (but not Rayleigh's) shows statistical significance for non randomly distributed expositions. The bedrock consists of dolomite and dolomitized limestone which is evident in the highest amounts of magnezium and calcium (Figure 3). Shallow, skeletous neutral to slightly basiphilous rendzinas prevail. The $\mathrm{O}_{h}$ horizon has highest amounts of calcium, magnezium, phosphorus and potassium of all studied soil profiles, while the A horizon showed the neutral chemical reaction $(\mathrm{pH}=7$; Table 3). In the tree layer, Abies alba $\left(100 \%^{73}\right)$ prevails over Fagus sylvatica $\left(100 \%^{56.9}\right)$, which is more an acception than a rule for the studied stands in the research area. Ulmus glabra and Sorbus aria (both $17 \%^{2.8}$ ), usually less frequent in other firbeech forest types, occur quite regulary, while Picea abies $\left(100 \%{ }^{20.8}\right)$ occurs in all relevés. Shrub and herb layers are well developed; shrubs cover up to $60 \%$ of the relevés ( $\mathrm{Me}=50 \%$ ), and the most frequent taxa, beside those from the tree layer, being Daphne mezereum $\left(100 \%{ }^{26.4}\right)$, Sambucus nigra $\left(100 \%^{20.8}\right)$, Rubus idaeus $\left(100 \%^{18.1}\right)$, Lonicera nigra $\left(83 \%^{18.1}\right)$ and Tilia platyphyllos $\left(50 \%^{8.3}\right)$. Herb layer covers round $80 \%$ of the relevés $(70-90 \%)$; with the highest presence and coverage occur Omphalodes verna $\left(100 \%^{44.4}\right)$, Mercurialis perennis $\left(100 \%^{38.9}\right)$, Maianthemum bifolium $\left(100 \%^{30.6}\right)$, Oxalis acetosella $\left(100 \%^{26.4}\right)$, Festuca altissima, Cardamine trifolia, Prenanthes purpurea, Solidago virgaurea (all $\left.100 \%{ }^{25}\right)$, Athyrium filix-femina $\left(100 \%^{22.2}\right)$, Calamintha grandiflora $\left(100 \%{ }^{20.8}\right)$, Aremonia agrimonoides, Polygonatum verticillatum, Dryopteris filix-mas, $M y$ celis muralis, Gentiana asclepiadea (all 100\% ${ }^{18.1}$ ), Asplenium trichomanes, Moehringia muscosa, Paris quadrifolia, Sorbus aucuparia (all $100 \%{ }^{16.7}$ ) and Epipactis helleborine $\left(100 \%{ }^{15.3}\right)$. Due to high coverage of herbs, moss layer is only modestly developed $(\mathrm{Me}=15 \%)$, rarely covering more than $20 \%$ of the relevé area. All in all, European beech forests species (Fagetalia sylvaticae) completely dominate in stands $\left(43 \%^{550}\right)$, while tall herbs (Mulgedio-Aconitetea - $4.6 \%^{8.3}$ ), rock dwellers (As- plenietea trichomanis $-4.6 \%{ }^{47.2}$ ) and generally thermophilous taxa (Quercetalia pubescentis $-2.8 \%{ }^{16.7}$ ) achieve one of the smallest presence and coverage values above all recognized fir-beech syntaxa in the study area. Diagnostically significant group of illyricoid taxa (Aremonio-Fagion) represents $8.3 \%$ of the total species inventory and one of the highest coverage values $\left(I_{c}=170.8\right)$. Hence, all associations'species, but Rhamnus fallax, and geographical character species, are present in all relevés with high coverage values.

Being one of the most mesophilous syntaxa within the fir-beech stands in the study area, we chose differential species from the group of European beech forests species (Fagetalia sylvaticae). Sambucus nigra $\left(100 \%^{20.8}\right)$ occurs most frequently in a shrub layer in all relevés with the highest coverage value, while Tilia platyphyllos $\left(50 \%^{8.3}\right)$ in half of the relevés but with significantly higher frequency and coverage with respect to other syntaxa. Although they do not occur in stands of the subassociation -sambucetosum exclusivelly, they are good indicators of deeper, humus rich and fresh, skeletous soils, and contribute much to the overall physiognomy of stands, rendering these forest types easy to recognize.

In only 6 relevés we identified 109 taxa of ferns and seed plants, but the highest number of taxa per relevé area averagelly (58; Figure 5). The lowest coefficient of variation of number of taxa per relevé (7.4\%) of all circumscribed syntaxa suggests rather homogenous species composition of the subassociation.

\section{Subassociation -asaretosum europaei Puncer 1980 var. Symphytum tuberosum var. nova (Table 14)}

These stands represent forests from the northwesternmost part of the distribution area of the association Omphalodo-Fagetum s.l. We found them on northern margin of the Vojsko plateau above the Kanomlja valley (Studenec clough) and at the headwaters of Sevnica stream under the Vojsko plateau between the Kanomljica and Idrijca rivers. They usualy thrive on shady (Figure 6) and steep slopes (Table 2) on mixed bedrock (marl of marl with clay slates, dolomite and black limestone with clay insertions, see Mlakar \& Čar 2009), between $640-800 \mathrm{~m}$ a.s.l, at the lower elevational limit of the association (Figures $4 \& 5$, Table 2). Fresh and relatively deep eutric soils (only occasionaly also dystric soils) prevail and are indicated by the occurance of Lamium or- 
vala, Scopolia carniolica, Senecio ovatus, Athyrium filix-femina, Doronicum austriacum and Blechnum spicant. These forests are heavily managed and in the tree layer, beside Fagus sylvatica and Abies alba, Picea abies, Acer pseudoplatanus and Ulmus glabra occur rather frequently, while Prunus avium, Fraxinus excelsior, Ostrya carpinifolia, Carpinus betulus and fuglans regia occur more sporadically (Table 4). In one relevé we even found Larix decidua (subspontaneously). Character species of the association are well represented, while differential species for the geographical variant Saxifraga cuneifolia lack; on the other hand, due to the presence of Calamintha grandiflora and the number and high coverage of other Illyrian taxa (Table 1), stands of the subassociation: -asaretosum europaei were classified into the geographical variant Calamintha grandiflora and represent a disjunct forests to the one distributed more towards south-eastern part of the association's distribution area (see also Surina 2002).

Subassociation Omphalodo-Fagetum var. geogr. Calamintha grandiflora asaretosum europaei was described by Puncer (1980) in the Kočevsko region (southern Slovenia) and is characterized by high proportion of beech (Fagetalia sylvaticae) and beech-oak (Querco-Fagetea) forests taxa and at the same time by lower proportion of spruce (Vaccinio-Piceetea) taxa. These stands host the highest number of illyricoid taxa (AremonioFagion) among all studied stands (Tables 1 and 4). Pulmonaria officinalis, Asarum europaeum ssp. caucasicum, Ulmus glabra, Hedera helix, Carex digitata and Primula vulgaris are differential taxa of the subassociation, while the differential species for the new variant are Petasites albus and Symphytum tuberosum. Differential taxa for the subassociation and the variant, and other species as well (e.g. Prunus avium) indicate favorable soil conditions in the lower montane belt in the contact area with submontane beech forests of the association Hacquetio-Fagetum. In many aspects (geological bedrock, soil conditions, elevation, distribution area; Figures 4 and 5) they represent marginal types of Dinaric fir-beech forests.

\section{Typification of the syntaxa}

Nomenclature types (holotypus) for the subassociations and variants:

Omphalodo-Fagetum var. geogr. Saxifraga cuneifolia adenostyletosum glabrae subass. nova: Tab. 5, relevé No. 9, holotypus hoc loco.
Omphalodo-Fagetum var. geogr. Saxifraga cuneifolia saxifragetosum cuneifoliae subass. nova: Tab. 6 , relevé No. 2, holotypus hoc loco.

Omphalodo-Fagetum var. geogr. Saxifraga cuneifolia calamagrostietosum arundinaceae subass. nova: Tab. 7, relevé No. 10, holotypus hoc loco.

Omphalodo-Fagetum var. geogr. Saxifraga cuneifolia festucetosum altissimae subass. nova: Tab. 8, relevé No. 4, holotypus hoc loco.

Omphalodo-Fagetum var. geogr. Saxifraga cuneifolia festucetosum altissimae subass. nova var. Calamagrostis arundinacea var. nova: Tab. 8, relevé No. 4 , holotypus hoc loco.

Omphalodo-Fagetum var. geogr. Saxifraga cuneifolia festucetosum altissimae subass. nova var. Lamium orvala var. nova: Tab. 8 , relevé No. 14, holotypus hoc loco.

Omphalodo-Fagetum var. geogr. Saxifraga cuneifolia festucetosum altissimae subass. nov. var. Saxifraga rotundifolia var. nova: Tab. 8 , relevé No. 22, holotypus hoc loco.

Omphalodo-Fagetum var. geogr. Saxifraga cuneifolia stellarietosum montanae subass. nova: Tab. 10, relevé No. 7, holotypus hoc loco.

Omphalodo-Fagetum var. geogr. Saxifraga cuneifolia stellarietosum montanae subass. nova var. Cardamine pentaphyllos var. nova: Tab. 10, relevé No. 16, holotypus hoc loco.

Omphalodo-Fagetum var. geogr. Saxifraga cuneifolia calamagrostietosum variae subass. nova: Tab. 11 , relevé No. 4, holotypus hoc loco.

Omphalodo-Fagetum var. geogr. Saxifraga cuneifolia seslerietosum autumnalis subass. nova: Tab. 12, relevé No. 4, holotypus hoc loco.

Omphalodo-Fagetum var. geogr. Saxifraga cuneifolia seslerietosum autumnalis subass. nova var. Platanthera bifolia var. nova: Tab. 12, relevé No. 4, holotypus hoc loco.

Omphalodo-Fagetum var. geogr. Saxifraga cuneifolia seslerietosum autumnalis subass. nova var. Polygonatum verticillatum var. nova: Tab. 12 , relevé No. 14, holotypus hoc loco.

Omphalodo-Fagetum var. geogr. Calamintha grandiflora sambucetosum nigrae subass. nova: Tab. 13 , relevé No. 3 , holotypus hoc loco.

Omphalodo-Fagetum var. geogr. Calamintha grandiflora asaretosum europaei Puncer 1980 var. Symphytum tuberosum var. nova: Tab. 14, relevé No. 3 , holotypus hoc loco. 


\section{DISCUSSION}

Fir-beech forests in north-western Dinaric Alps (Omphalodo-Fagetum s.l.) represent a climatogenic vegetation type in (upper) montane - (alti)montane belt, where the association's character species, and many other illyricoid taxa, achieve their biological optimum. However, along the distribution range of the association, there is a marked decline in presence of characteristic taxa for the association Omphalodo-Fagetum and the alliance Aremonio-Fagion towards north-west (Surina 2002). This is not only due to the biogeographical peculiarities of the Trnovski gozd platau (at the north-western most limit of association's distribution range and thus the presence of the de-alpine elements due to the close proximity of the Julian Alps), but also due to the geological bedrock; in the central part of the plateau limestone (and in a lesser extent dolomite) is substituted with chert which siginificantly reduces the number and coverage of generally calcifitic illyricoid taxa. This is well represented in the two most frequent types of the association, -calamagrostietosum arundinacei and -festucetosum altissimae, being in comparisson to other types of the association floristically impoverished (Tables 1, 2, 4, 7-9). Diversified karstic relief, extensive elevational gradient, considerable differences in geological bedrock and soil depth already in a scale of only a few meters, render
Dinaric fir-beech stands in the Trnovski gozd plateau (but in other parts of the Dinaric Alps as well) as one of the most diverse forest stands in terms of biodiversity: the complete floristic inventory based only on our own relevés includes round 400 taxa of ferns and seed plants. Environmental heterogeneity leads to a strong floristical and ecological differentiation of the climatogenic forest types. Within the association Omphalodo-Fagetum var. geogr. Saxifraga cuneifolia, we identified 10 forest types at the subassociation rank and several types at the rank of variant (Tables 4-14, Figures 3-9) which is in accordance to the high number of recognized fir-beech forest types in other parts of the Dinaric Alps (Omphalodo-Fagetum var. geogr. Calamintha grandiflora; e.g. Tregubov 1957, Puncer et al. 1974, Puncer 1980, Accetto 1998).

In his original study, Puncer (1979 mscr.) treated fir-beech stands in the Trnovski gozd plateau as a new, »small« association Abieti-Fagetum praealpino-dinaricum Puncer 1979 nom. nud., trying to stress its transitional character between the Dinaric and pre-Alpine fir-beech stands. Hence, following the principle of multi-dimensional subdivision of syntaxa (Matuszkiewicz \& Matuszkiewicz 1981), we desided to apply the name $\mathrm{Om}$ phalodo-Fagetum for these stands, and within the newly described geographical variant -Saxifraga cuneifolia (Surina 2002) find new vicariant names for the syntaxa of the subassociation rank, e.g.:

\section{var. geogr. Saxifraga cuneifolia}

saxifragetosum cuneifoliae subass. nova hoc loco stellarietosum montanae subass. nov. hoc loco festucetosum altissimae subass. nov. hoc loco adenostyletosum glabrae subass. nov. hoc loco rhododendretosum hirsuti Dakskobler et al. 2000 calamagrostietosum arundinaceae subass. nov.

hoc loco seslerietosum autumnalis subass. nov. hoc loco calamagrostietosum variae subass. nov. hoc loco

\section{var. geogr. Calamintha grandiflora}

homogynetosum sylvestris Tregubov 1957

aceretosum pseudoplatani Puncer et al. 1974

festucetosum altissimae Puncer 1980

adenostyletosum glabrae Puncer 1980

sambucetosum nigrae subass. nov. hoc loco asaretosum europaei Puncer 1980

Within the geographical variant Calamintha grandiflora, which in the Trnovski gozd plateau represents Dinaric fir-beech stands at its northeastern margin of the plateau only, we identified stands which resemble much to the stands described by Puncer (1980). He classified them into the subassociation -asaretosum europaei and we retained his proposal. Otherwise, while pre- serving the names already used by the researchers in the tipology of Dinaric fir-beech stands for the geographical variant Calamintha grandiflora, we proposed for the respective stands in the Trnovski gozd plateau and within the geographical variant Saxifraga cuneifolia new names for the syntaxa: -festucetosum altissimae and -adenostyletosum glabrae. During our initial research in the field, and co- 
firmed with subsequent numerical analyses, we encountered several typological problems both within the forests of the syntaxon Ompalodo-Fagetum var. geogr. Saxifraga cuneifolia and between the forests of similar - contact syntaxa. This may be a biological reality but in many cases also a consequence of intensive forest management as well. At their upper elevational limit, fir-beech forests of the subassociations -rhododendretosum hirsuti and -adenostyletosum glabrae frequently form transitional stands with altimontane (Ranunculo platanifolii-Fagetum) and subalpine beech forests (Polysticho lonchitis-Fagetum) which are difficult to classify. However, these stands show considerable floristic similarities with fir-beech forests of the association Homogyno sylvestris-Fagetum from the pre-Alpine area which is in accordance with their biogeographic position. Dinaric fir-beech stands (the subassociation -asaretosum in particular) on their lower elevational limit form transitional forests to the stands of the association HacquetioFagetum. Within the syntaxon Omphalodo-Fagetum var. geogr. Saxifraga cuneifolia we observed continuous transition of forests of the subassociation -festucetosum altissimae to forests of the subassociation -calamagrostietosum arundinaceae (Figures 4 and 5); higher elevation, cooler and moister sites are frequent and indicated by high coverage of Festuca altissima, while dryer, sunny slopes and acidic soils low on nutrients prefers Calamagrostis arundinacea (Figure 7).

\section{ACKNOWLEDGEMENTS}

The paper presents the results of the research performed at the Institute of Biology, Scientific Research Centre of the Slovenian Academy of Sciences and Arts (Ljubljana, Slovenia) in the frame of Master Thesis of the first author under the supervision of the second author and late Prof. Dr. Tone Wraber. Academician Dr. Mitja Zupančič, late Prof. Dr. Tone Wraber and Dr. Branko Vreš allowed a continuous exchange of experience and immediate feedback on potential problems during the research. Branko Vreš and Tomaž Seliškar helped in solving many technical issues during data analyes and manuscript preparation. Mr.Sc. Tomaž Prus did the soil analyses. Valuable information during our field work were given by foresters Alfred Gruden (Nemci), Franc Likar (Predmeja) as well as Igor Kuščer and Jože
Črmelj, heads of the Local units Trnovo and Predmeja of the Slovenian Forest Service, respectively. Two anonymous reviewers helped us with valuable improvements and corrections. Our sincere gratitude goes to all of them.

\section{REFERENCES}

Accetto, M. 1998: Dinarsko jelovo bukovje z gorsko bilnico v Kočevskem rogu. Zbornik gozdarstva in lesarstva 56: 5-31.

Adamović, L. 1909: Vegetationsverhältnisse der Balkanländer (Mösische Länder). Verlag von Wilhelm Engelmann, Leipzig, 567 pp.

Aeschimann, D., Lauber, K., Mosser, D. M. \& Theurillat, J.-P. 2004: Flora alpina. Band 1-3. Haupt Verlag, Bern, Stuttgart, Wien, 1159 pp.+ 1188 pp. +322 pp.

Barkman, J. J., Moravec, J., Rauschert, S. 1986: Code of the phytosociological nomenclature. Vegetatio 67(3): 145-195.

Beck, G. 1906: Die Umkehrung der Pflanzenregionen in den Dolinen des Karstes. Sitzungber. d. Akad. d. Wiss. Wien, Mathem. -naturw. Kl. Bd. 115(1-10): 3-19.

Beck, G. 1901: Die Vegetationsverhältnisse der illyrischen Länder. Verlag von Wilhelm Engelmann, Leipzig. 534 pp.

Bertović, S., Cestar, D., Pelcer, Z. 1966: Prilog poznavanju proizvodnih mogućnosti šume bukve $\mathrm{s}$ jelom (Fagetum croaticum abietetosum Horv.) na Ličkoj Plješivici. Radovi Šumarskog instituta 5(2): 1-62.

Blečić, V. 1958: Šumska vegetacija i vegetacija stena i točila doline reke Pive. Glasnik prirodnjačkog muzeja u Beogradu Serija B 11:1-108.

Borhidi, A. 1963: Die Zönologie des Verbandes Fagion illyricum. I. Allgemeiner Teil. Acta Botanica Hungarica 9: 259-297.

Borhidi, A. 1965: Die Zönologie des Verbandes Fagion illyricum, II. Systematischer Teil. Acta Botanica Hungarica 11(1-2): 53-102.

Braak, Ter J. F. C. \& Šmilauer, P. 2002: CANOCO Reference Manual and CanoDraw for Windows. User's guide to Canoco for Windows: Software for Cacnonical Community Ordination (version 4.5). Microcomputer Power (Ithaca, NY, USA), New York, xy pp.

Braun-Blanquet, J. 1964: Pflanzensoziologie. Grundzüge der Vegetationskunde. 3. Auflage. Springer, Wien - New York, 865 pp. 
Brus, R. 2010: Growing evidence for the existence of glacial refugia of European beech (Fagus sylvatica $\mathrm{L}$.) in the south-eastern Alps and northwestern Dinaric Alps. Periodicum Biologorum 112(3): 239-246.

Brus, R., Horvat-Marolt, S., Paule, L. 2000: Nova spoznanja $\mathrm{v}$ obstoju ledenodobnih zatočišč bukve (Fagus sylvatica L.) na ozemlju današnje Slovenije. In: Potočnik, I. (ed.): Nova znanja v gozdarstvu - prispevek visokega šolstva. Biotehniška fakulteta, Oddelek za gozdarstvo in obnovljive gozdne vire, Ljubljana, pp. 77-88.

Buser, S. 1965: Geološke razmere v Trnovskem gozdu. Geografski vestnik 37: 123-135.

Chytrý, M. \& Otýpková, Z. 2003: Plot sizes used for phytosociological sampling of European vegetation. Journal of Vegetation Science 14 (4): 563-570.

Čampa, L. 1978: Gozdne združbe in rastiščnogojitveni tipi v gospodarski enoti Idrija II. Biro za gozdarsko načrtovanje, Ljubljana, 88 pp.

Dakskobler, I. 1997: Geografske variante asociacije Seslerio autumnalis-Fagetum (Ht.) M. Wraber ex Borhidi 1963. Razprave IV. razreda SAZU 38(8): 165-255.

Dakskobler, I. 1998: Vegetacija gozdnega rezervata Govci na severovzhodnem robu Trnovskega gozda (zahodna Slovenija). In: Diaci, J. (ed.): Zbornik referatov: XIX. gozdarski študijski dnevi. Logarska dolina, pp. 269-301.

Dakskobler, I. 1999: Contribution to the knowledge of the association Fraxino orni-Pinetum nigrae Martin-Bosse 1967. Wiss. Mitt.Niederösterr.Landesmuseum 12: 25-52.

Dakskobler, I. 2003: Asociacija Rhododendro hirsuti-Fagetum Accetto ex Dakskobler 1998 v zahodni Sloveniji. Razprave IV. razreda SAZU 44(2): 5-85.

Dakskobler, I. 2004: Posebnosti rastja in rastlinstva Govcev na severnem robu Trnovskega gozda nad dolino Trebuše. Gozdarski vestnik 62(5-6): 270-280.

Dakskobler, I. 2008: A review of beech sites in Slovenia. Zbornik gozdarstva in lesarstva 87: 3-14.

Dakskobler, I., Urbančič, M., Wraber, A. 2000: Gozd bukve in jelke z dlakavim slečem Omphalodo-Fagetum (Tregubov 1957) Marinček et al. 1993 rhododendretosum hirsuti (Urbančič et al. 1979 nom. nud.) subass. nova v Trnovskem gozdu (zahodna Slovenija). Zbornik gozdarstva in lesarstva 62: 5-52.

Dakskobler, I. \& Marinšek, A. 2009: Pregled jelovih rastišč v Sloveniji. Zbornik gozdarstva in lesarstva 89: 43-54.

Dierschke, H. 1994: Pflanzensoziologie. Eugen Ulmer Verlag, Stuttgart, 683 pp.

Fukarek, P. 1964: Fitocenološka istraživanja Igmana. Elaborat. Institut za šumarstvo u Sarajevu, Sarajevo, $234 \mathrm{pp}$.

Fukarek, P. \& Stefanović, V. 1958: Prašuma Peručica i njena vegetacija. Radovi Poljoprivrednošumarskog fakulteta 3(3): 93-146.

Gauch, H. G. 1999: Multivariate analysis in community ecology. Cambridge Unviersity Press, Cambridge, $298 \mathrm{pp}$.

Hammer, O. \& Harper, D. A. T. 2006: Paleontological data analysis. Blackwell Publishing, Oxford, $351 \mathrm{pp}$.

Hammer, O., Harper, D. A. T., Ryan, P. D. 2001: Paleontological Statistics Software Package for Education and Data Analysis. Palaeontologia Electronica 4(1): 1-9; http://palaeo-electronica.org/2001 1/past/issue1 $01 \mathrm{htm}$.

Horvat, I. 1938: Biljnosociološka istraživanja šuma u Hrvatskoj. Glasnik za šumske pokuse 6: 127-256.

Horvat, I., Glavać, V. \& Ellenberg, H. 1974: Vegetation Südosteuropas. Gustav Fischer Verlag, Stuttgart, $768 \mathrm{pp}$.

Krašan, F. 1880: Vergleichende Übersicht der Vegetationsverhältnisse der Grafschaften Görz und Gradisca. Österreichische Botanische Zeitschrift 30(9): 281-286.

Lausi, D., Gerdol, R., Piccoli, F. 1982: Dynamics of Ostrya carpinifolia woods in the Southern Alps (N-Italy). Vegetatio 48: 123-131.

Lepš, J. \& Šmilauer, P. 2003: Multivariate Analysis of Ecological Data using CANOCO. Cambridge University Press, Cambridge, 269 pp.

Magri, D., Vendramin, G. G., Comps, B., Dupanloup, I., Geburek, T., Gömöry, D., Latałowa, M., Litt, T., Paule, L., Roure, J. M., Tantau, I., van der Knaap, W. O., Petit, R. J. \& Beaulieu, J.-L. 2006: A new scenario for the Quaternary history of European beech populations: palaeobotanical evidence and genetic consequences. New Phytologist 171: 199-221.

Mardia, V. 1972: Statistics of Directional Data. Academic Press, London, 357 pp.

Marinček, L. 1996: Subalpine Buchewälder in den Westlichen Dinariden (Polysticho lonchitisFagetum var. geogr. Allium victorialis var. geogr. nova). Annali dei Musei Civici di Rovereto.Sez.: Arch., St., Sc. nat. Suppl. II 11: 197-208. 
Marinček, L. \& Košir, P. 1998: Dinaric Fir-beech Forests (Omphalodo-Fagetum (Tregubov 1957) Marinček et al. 1993) on Blegoš. Hladnikia 10: 29-40.

Marinček, L., Mucina, L., Zupančič, M., Poldini, L., Dakskobler \& I., Accetto, M. 1993: Nomenklatorische Revision der illyrischen $\mathrm{Bu}$ chenwälder (Verband Aremonio-Fagion). Studia Geobotanica 12 (1992): 121-135.

Marinček, L., Puncer, I. \& Zupančič, M. 1977: Vegetacijska in rastiščna analiza za G. e. Trnovo. Soško gozdno gospodarstvo Tolmin, Ljubljana, $47 \mathrm{pp}$.

Markgraf, F. 1927: An den Grenzen des Mittelmeergebiets. Pflanzengeographie von Mittelalbanien. Beihefte 45: 1-217.

Martinčič, A. 1977: Prispevek k poznavanju ekologije mrazišč v Sloveniji. Botanično-ekološka skica. Razprave IV. razreda SAZU 20: 231-316.

Martinčič, A. 2003: Seznam listnatih mahov (Bryopsida) Slovenije. Hacquetia 2(1): 91-166.

Martinčič, A., Wraber, T., Jogan, N., Podobnik, A., Turk, B., Vreš, B., Ravnik, V., Frajman, B., Strgulc-Krajšek, S., Trčak, B., Bačič, T., Fischer, M. A., Eler, K. \& Surina, B. 2007: Mala flora Slovenije. Tehniška založba Slovenije, Ljubljana, 967 pp.

Matuszkiewicz, W. \& Matuszkiewicz, A. 1981: Das prinzip der mehrdimenzionalen Gliederung Vegetationseinheiten, erläutert am Beispiel der Eichen-Hainbuchenwälder in Polen. In: Dierschke, H. (ed.): Syntaxonomie. -Ber. Int. Symp. Int. Vereinig. Vegetationsk. Rinteln. J. Cramer, Vaduz, pp. 123-148.

Mucina, L., Grabherr, G. \& Wallnöfer, S. 1993: Pflanzengesellschaften Österreichs Teil III: Wälder und Gebüsche. Gustav Fischer, Jena - Stuttgart - New York, 353 pp.

Oberdorfer, E. 1994: Pflanzensoziologische Exkursionsflora. Ulmer, Stuttgart, $1050 \mathrm{pp}$.

Pelcer, Z. 1976: Tipološke značajke šuma u gospodarskoj jedinici "Crni lug". Radovi 26: 11-22.

Pignatti, S. 2005: Valori di bioindicazione delle piante vascolari della flora d'Italia. Braun-Blanquetia 39: 1-97.

Piskernik, M. 1954: Združba gorskega javorja in bresta (Acereto-Ulmetum) v Snežniku, Javorni$\mathrm{ku}$ in Trnovskem gozdu. Diplomska naloga. Biotehniška fakulteta, Oddelek za biologijo, Ljubljana, 20 pp.

Podani, J. 2001: SYN-TAX 2000. Computer programs for data analysis in ecology and systematics. Users's manual. Scientia, Budapest, 53 pp.
Puncer, I. 1979: Ekološke in floristične značilnosti združbe Abieti-Fagetum na Trnovskem gozdu. In: Rauš, Dj. (ed.): Drugi kongres ekologa Jugoslavije II. Savez društava ekologa Jugoslavije, Zagreb, pp. 925-938.

Puncer, I. 1980: Dinarski jelovo bukovi gozdovi na Kočevskem. Razprave IV. razreda SAZU 22(6): 401-546.

Puncer, I., Wojterski, T. \& Zupančič, M. 1974: Der Urwald Kočevski Rog in Slowenien (Jugoslawien). Fragmenta Floristica et Geobotanica 20(1): 41-87.

Seliškar, T., Vreš, B. \& Seliškar, A. 2003: FloVegSi 2.0 - Računalniški program za urejanje in analizo bioloških podatkov. Biološki inštitut ZRC SAZU, Ljubljana.

Suppan, U., Prügger, J. \& Mayrhofer, H. 2000: Catalogue of the lichenized and lichenicolous fungi of Slovenia. Bibliotheca Lichenologica 76: 5-215.

Surina, B. 2001: Fitocenološke raziskave jelovo-bukovega gozda (Omphalodo-Fagetum s. lat.) v zahodnem delu ilirske florne province. Magistrska naloga. Biotehniška fakulteta Univerze v Ljubljani, Oddelek za biologijo, Ljubljana, 99 pp.

Surina, B. 2002: Phytogeographical differentiation in the Dinaric fir-beech forest (Omphalodo-Fagetum s. lat.) of the western part of the Illyrian floral province. Acta Botanica Croatica 61(2): 145-178.

Surina, B. \& Vreš, B. 2009: The association Drepanoclado uncinati-Heliospermetum pusilli (Arabidetalia caeruleae, Thlaspietea rotundifolii) in the Trnovski gozd plateau (Slovenia, NW Dinaric Mts). Hacquetia 8(1): 31-40.

Šercelj, A. 1996: Začetki in razvoj gozdov v Sloveniji. Dela, Slovenska akademija znanosti in umetnosti, Razred za naravoslovne vede 35 , Ljubljana, 142 pp.

Taberlet, P., Fumagalli, L., Wust-Saucy, A.-G. \& Cosson, J.-F. 1998: Comparative phylogeography and postglacial colonization routes in $\mathrm{Eu}-$ rope. Molecular Ecology 7: 453-464.

Török, K., Podani, J. \& Borhidi, A. 1989: Numerical revision of the Fagion illyricum alliance. Vegetatio 81: 169-180.

Tregubov, V. 1941: Les forets vierges montagnardes des Alps Dinariques. Massif de Klekovatcha - Guermetch. Étude Botanique et Foresetiere. These de doctorat. Montpellier, Causse, Graille et Castelanu, 118 pp.

Tregubov, V. 1957: Gozdne rastlinske združbe. In: Tregubov, V. \& Čokl, M. (eds.): Prebiralni 
gozdovi na Snežniku. Kmečka knjiga, Ljubljana, pp. 23-65.

Trinajstić, I. 1970: Prilog poznavanju šumske vegetacije prašumskog rezervata "Čorkova uvala" u Hrvatskoj. ANU BiH, posebna izdanja 15(4): 125-130.

Trinajstić, I. 1972: O rezultatima komparativnih istraživanja florističnog sastava prašumskih i gospodarskih sastojina zajednice Fagetum croaticum abietetum $\mathrm{Ht}$. u Hrvatskoj. Šumarski list 9-10: 334-346.

Trinajstić, I. 1997: Phytogeographical analysis of the illyricoid floral element. Acta Biologica Slovenica 41(2-3): 77-85.

Trinajstić, I. 2008: Plant communities of Croatia. Akademija šumarskih znanosti, Zagreb, 179 p.

Trinajstić, I., Franjić J. \& Škvorc, Ž. 2009: The nomenclatural and syntaxonomic analysis of the Dinaric beech and fir forests (Fago-Abietetum Tregubov 1941 corr. Trinajstić 2007). In: Matić, S. \& Anić, I. (eds.): Zbornik radova znanstvenog skupa Prašumski ekosustavi dinarskoga krša i prirodno gospodarenje šumama u Hrvatskoj. Hrvatska akademija znanosti i umjetnosti, Zagreb, pp. 101-113.

Turk, M. 1994: Predlog etata in gozdnogojitvenih del. GGE Predmeja, 1994-2003. Elaborat. ZGS izpostava Tolmin, območna enota Ajdovščina, Ajdovščina, $240 \mathrm{pp}$.

Urbančič, M., Azarov, E., Čampa, L. \& Žgajnar, A. 1979: Gozdne združbe in rastiščnogojitveni tipi v gospodarski enoti Predmeja. Biro za gozdarsko načrtovanje, Ljubljana, 205 pp.

Urbančič, M. \& Dakskobler, I. 2001: Spremembe talnih razmer in rastlinske sestave v črnem borovju (Fraxino orni-Pinetum nigrae) in bukovju $\mathrm{z}$ dlakavim slečem (Rhododendro hirsuti-Fagetum) po požaru. Zbornik gozdarstva in lesarstva 66: 95-137.

van der Maarel E. 1979: Transformation of coverabundance values in phytosociology and its effects on community similarity. Vegetatio 39(2): 97-114.

Vovk, B., Kodrič, M., Stepančič, D. \& Ažnik, M. 1966: Tla sekcije Trst 2. Institut za tla in prehrano rastlin Biotehniske fakultete v Ljubljani, Ljubljana, 48 pp.

Vukelić, J. \& Baričević, D. 1996: Fitocenološka usporedba dinarskih i panonskih bukovo-jelovih šuma (Abieti-Fagetum s. 1.) u Hrvatskoj. In: Gračan, S. (ed.): Skrb za hrvatske šume od 1846. do 1996. Unapredjenje proizvodnje bio- mase šumskih ekosustava, 1. Hrvatsko šumarsko društvo, Zagreb, pp. 87-95.

Vukelić, J. \& Baričević, D. 2002: Phytosociological Comparison of Virgin Forests of Štirovača in the Central Velebit (Croatia) and in the Kočevski Rog (Slovenia). Hacquetia 1(1): 23-34.

Vukelić, J., Mikac, S., Baričević, D., Bakšić, D. \& Rosavec, R. 2008: Forest Sites and Forest Communities in Croatia. National Ecological Network. State Institute of Nature Protection, Zagreb, 263 pp.

Weber, H. E., Moravec, J. \& Theurillat, J.-P. 2000: International Code of Phytosociological Nomenclature. 3rd edition. Journal of Vegetation Science 11(5): 739-768.

Westhoff, V. \& van der Maarel, E. 1973: The Braun-Blanquet approach. In: Whittaker, R. H. (ed.): Ordination and Classification of Communities. Handbook of Vegetation Science 5. Dr. W. Junk b.v.-Publishers, The Hague, pp. 619-726.

Willis, K. J. \& van Andel, T. H. 2004: Trees or no trees? The environments of central and eastern Europe during the Last Glaciation. Quaternary Sciences Reviews 23: 2369-2387.

Willner, W., Di Pietro, R. \& Bergmeier, E. 2009: Phytogeographical evidence for post-glacial dispersal limitation of European Beech forest species. Ecography 32: 1011-1018.

Wraber, M. 1953: Fitosociološka slika Trnovskega gozda (G. u. Trnovo, G. g. Most na Soči). Elaborat. Biološki inštitut SAZU, Ljubljana, $21 \mathrm{pp}$.

Wraber, M. 1959: Fitocenološka opredelitev gozdne vegetacije na področju gozdnega obrata Predmeja v Trnovskem gozdu. Elaborat. Inštitut za biologijo SAZU, Ljubljana, $46 \mathrm{pp}$.

Wraber, M. 1963: Fitosociološka in ekološka podoba gozdne vegetacije na Idrijskem. Elaborat. Inštitut za biologijo SAZU, Ljubljana, 65 pp.

Wraber, T. 2004: Rastlinstvo goriške okolice in njegovi raziskovalci. Goriški letnik 30-31: 171-192.

Zupančič, B. 1995: Klimatografija Slovenije, količina padavin, obdobje 1960-1990. Ministrstvo za okolje in prostor, Hidrometeorološki zavod Republike Slovenije, Ljubljana, 366 pp.

Zupančič, M. 1969: Vergleich der BergahornBuchengesellschaften (Aceri-Fagetum) im alpinen und dinarischen Raume. Mitteilungen der Ostalpin-dinarischen Arbeitgemeinschaft 9: 119-131. 
Zupančič, M. 1999: Smrekovi gozdovi Slovenije (Spruce forests in Slovenia). Dela IV. razreda SAZU 36: 7-222.

Zupančič, M. 1980: Smrekovi gozdovi v mraziščih dinarskega gorstva Slovenije. Biološki inštitut Jovana Hadžija, ZRG SAZU, Ljubljana, 262 pp.

Zupančič, M. 1967: Der dinarische Bergahorn - Buchenwald (Aceri-Fagetum dinaricum) im slowenischen Hochkarstgebiet. Mitteilungen der Ostalpin-dinarischen Arbeitgemeinschaft 7: 89-96.

\section{APPENDIX}

\subsection{TAXA OGCURING ONLY ONCE IN ANALYTICAL TABLES.}

Table 5. Omphalodo-Fagetum var. geogr. Saxifraga cuneifolia adenostyletosum glabrae

2 (+) Corallorhiza trifida; (r) Polystichum lonchitis; 3 (+) Camptothecium lutescens, Clematis vitalba, Mnium sp., Polystichum x luerssenii; 4 (+) Fissidens taxifolius; 5 (1) Hacquetia epipactis; (+) Encalypta streptocarpa; 6 (2) Calamagrostis villosa; 7 (+) Grimia pulvinata, Piptatherum virescens, Plagiochila asplenioides; 8 (+) Cladonia pyxidata, Rhododendron hirsutum; 9 (r) Carex ornithopoda; 11 (1) Homogyne sylvestris; 12 (+) Rhizomnium punctatum, Rhytidiadelphus loreus; 13 (r) Cystopteris regia, Sambucus racemosa; $14(+)$ Valeriana montana; 15 (+) Homalothecium lutescens, Plagiomnium cuspidatum; 17 (+) Eurhynchium striatum.

Table 6. Omphalodo-Fagetum var. geogr. Saxifraga cuneifolia saxifragetosum cuneifoliae

1 (+) Bazzania trilobata, Polystichum x illyricum; $2(+)$ Lonicera xylosteum, Melittis melissophyllum; 6 (1) Rhytidiadelphus triquetrus; (+) Brachythecium erythrorhizon, Bryum capillare, Bryum sp., Calliergon sp., Campylium halleri, Cirriphyllum piliferum, Fissidens dubius, Herzogiella seligeri, Hypnum sauteri, Icmadophila ericetorum, Isothecium myurum, Lepidozia reptans, Leptobryum pyriforme, Lescuraea saxicola, Mnium marginatum, Odontoschisma denudaum, Plagiothecium undulatum, Platygyrium repens, Plagiopus oederi, Rhizomnium punctatum, Tetraphis pellucida; (r) Dactylorhiza maculata; 7 (+) Cardamine pentaphyllos, Mnium ambiguum, Platanthera bifolia; 8 (+) Carex brachystachys, C. ferruginea, Oncophorus virens, Plagiomnium undulatum, Polystichum braun$i i ; 9$ (+) Melampyrum sylvaticum, Ribes alpinum, Vi-
Zupančič, M. \& Accetto, M. 1994: Ribeso alpini-Piceetum ass. nova v Dinarskem gorstvu Slovenije. Razprave IV. razreda SAZU 35(9): 151-175. Zupančič, M. \& Puncer, I. 1995: Über zwei weniger bekannte Urwälder Krokar und Strmec in Slowenien. Sauteria 6: 139-156.

Received 19. 1. 2012

Revision received 17. 10. 2012

Accepted 19. 10. 2012

ola biflora; $10(+)$ Thalictrum aquilegiifolium; $11(+)$ Viola riviniana; 13 (+) Peltigera canina; 14 (1) Anemone trifolia, Melica nutans; (+) Convallaria majalis; 15 (r) Neottia nidus-avis; 16 (1) Sanicula europaea; 17 (+) Cardamine impatiens, Milium effusum; 18 (+) Atrichum undulatum; 19 (+) Neckera complanata.

Table 7. Omphalodo-Fagetum var. geogr. Saxifraga cuneifolia calamagrostietosum arundinaceae

2 (+) Cirsium erisithales, Hypericum perforatum; 3 (+) Carex alba; 4 (+) Polystichum braunii, Salvia glutinosa; 5 (r) Clematis vitalba; 8 (+) Cystopteris montana; 12 (r) Cardamine impatiens, Polystichum lonchitis; 13 (r) Doronicum austriacum; 14 (+) Luzula pilosa, Salix appendiculata; 15 (1) Fraxinus excelsior, Orthilia secunda; 16 (r) Impatiens nolitangere; 17 (+) Petasites albus; 18 (+) Arabis alpina, A. hirsuta, Sedum hispanicum; 19 (+) Corylus avellana; 22 (+) Cruciata glabra, Galium rotundifolium; 24 (1) Arabis turrita; 26 (+) Collema flaccidum; 28 (+) Helleborus odorus, Milium effusum; 29 (r) Atropa bella-dona, Eupatorium cannabinum; 30 (+) Veronica montana, Viola reichenbachiana; 31 (+) Phyteuma ovatum; 32 (r) Chrysosplenium alternifolium, Phyllitis scolopendrium; 34 (+) Asarum europaeum ssp. caucasicum, Cardamine bulbifera, Heracleum sphondylium, Pulmonaria officinalis, Symphytum tuberosum; (r) Peucedanum austriacum.

Table 8. Omphalodo-Fagetum var. geogr. Saxifraga cuneifolia festucetosum altissimae $\mathbf{I}$

1 (+) Hypericum perforatum, Moehringia trinervia, Orthilia secunda, Peltigera canina, Tilia platyphyllos; 2 (+) Deschampsia cespitosa, Poa nemoralis; 3 (+) Anemone x pittonii, Cirsium erisithales; 4 (+) Monotropa hypopitys; 11 (+) Aegopodium podagraria, Arabis turrita; 13 (+) Circaea lutetiana, Phyteuma spicatum; 15 (+) Tortella tortuosa; 17 (+) Atropa bella-dona, Cephalanthera damasonium, Platanthera bifolia, 
Sesleria autumnalis; 18 (+) Asplenium ruta-muraria; 19 (1) Euphorbia amygdaloides; 20 (+) Carex sylvatica; 21 (+) Hylocomium splendens, Radula complanata; 22 (1) Polystichum lonchitis; (+) Clematis alpina, Thuidium tamariscinum; 23 (+) Huperzia selago; (r) Cystopteris montana; $24(+)$ Collema flaccidum, Ribes alpinum; 25 (+) Doronicum austriacum.

Table 9. Omphalodo-Fagetum var. geogr. Saxifraga cuneifolia festucetosum altissimae II

1 (1) Lathyrus vernus ssp. vernus; (+) Anemone trifolia, Cephalanthera damasonium; 2 (+) Cruciata glabra; 3 (+) Thamnobryum alopecurum; 4 (+) Antitrichia curtipendula, Homalothecium philippeanum; 5 (1) Galeopsis speciosa, Corylus avellana; (+) Adoxa moschatellina, Circaea alpina, Cladonia digitata, Cystopteris fragilis; 6 (+) Cladonia coniocraea, Polystichum x luerssenii, Urtica dioica; 10 (+) Thuidium tamariscinum, Valeriana tripteris; 11 (+) Cymbalaria muralis, Hedera helix, Heracleum sphondylium, Ostrya carpinifolia, Viscum album ssp. abietis, Pyrola minor; 14 (+) Cyclamen purpurascens; 17 (+) Doronicum austriacum; 19 (+) Euphorbia amygdaloides, Hieracium murorum, Phyteuma spicatum, Saxifraga rotundifolia; 20 (+) Chrysosplenium alternifolium, Dactylorhiza maculata, Piptatherum virescens, Ranunculus lanuginosus; 21 (+) Symphytum tuberosum, Veronica montana; 25 (+) Ajuga reptans, Blechnum spicant, Galium rotundifolium; 27 (+) Carex alba, Clematis alpina, Galium mollugo, Monotropa hypopitys, Platanthera bifolia, Veronica officinalis.

Table 10. Omphalodo-Fagetum var. geogr. Saxifraga cuneifolia stellarietosum montanae

$2(+)$ Cymbalaria muralis, Fraxinus ornus; $3(+)$ Cardamine flexuosa, Scrophularia vernalis; $4(+)$ Asplenium viride, Cladonia digitata; 7 (+) Mnium marginatum, M. spinosum, Rhizomnium punctatum; 8 (+) Geum urbanum; 10 (+) Neottia nidus-avis; 11 (+) Deschampsia cespitosa, Mnium orthorrhynchium, Plagiothecium sp.; 12 (+) Luzula sylvatica ssp. sylvatica, Thudium tamariscinum; 13 (+) Plagiothecium sylvaticum; 14 (+) Calamagrostis varia, Digitalis grandiflora, Eunoymus latifolia, Fraxinus excelsior, Hypericum maculatum, Polystichum x illyricum, Rosa pendulina; (r) Cirsium erisithales, Primula vulgaris; 15 (+) Aruncus dioicus; (r) Ostrya carpinifolia, Sorbus aria; 18 (+) Allium ursinum, Anemone ranunculoides, Anthriscus nitida; 19 (+) Neckera complanata, Plagiomnium cuspidatum; 20 (+) Eupatorium cannabinum, Peltigera canina; 21 (+) Aconitum degenii ssp. paniculatum, Dactylis polygama, Epipactis helleborine, Galanthus nivalis, Poa nemoralis.
Table 11. Omphalodo-Fagetum var. geogr. Saxifraga cuneifolia calamagrostietosum variae

1 (+) Camptothecium lutescens, Festuca altissima, Pulmonaria officinalis, Sorbus aucuparia, Ulmus glabra, Verbascum lanatum; 2 (+) Ilex aquifolium; 3 (1) Aquilegia nigricans; (+) Orthothecium rufescens; (r) Digitalis grandiflora; 4 (+) Betonica alopecuros; (r) Valeriana saxatilis; 5 (1) Anemone trifolia; (+) Anemone x pittonii, Laserpitium peucedanoides; ( $\mathrm{r}$ ) Euonymus latifolia; 6 (+) Prunus avium; 7 (+) Epilobium montanum, Peltigera canina; (r) Ranunculus platanifolius; 8 (+) Angelica sylvestris, Galium odoratum, Petasites albus; (r) Euonymus verrucosa, Lunaria rediviva; 9 (+) Carex humilis; 14 (+) Cephalanthera damasonium, Polystichum x bicknellii; 15 (+) Bartramia halleriana, Dryopteris affinis, Taxus baccata; 16 (+) Carex brachystachys, Peucedanum austriacum, Potentilla carniolica; 17 (+) Cladonia pyxidata, Mnium thomsonii, Phyllitis scolopendrium, Poa nemoralis, Solanum dulcamara; (r) Hieracium lachenalii, Sambucus racemosa.

Table 12. Omphalodo-Fagetum var. geogr. Saxifraga cuneifolia seslerietosum autumnalis

1 (+) Clematis vitalba, Hieracium murorum, Orthilia secunda; 4 (r) Cardamine impatiens, Thalictrum aquilegiifolium; 9 (+) Lilium martagon, Melica nutans, Vaccinium myrtillus; 11 (+) Arabis turrita, Asarum europaeum ssp. caucasicum, Ulmus glabra; 12 (+) Frangula alnus; 13 (+) Aposeris foetida, Helleborus odorus, Luzula pilosa, Mnium spinosum, Plagiomnium affine, Plagiothecium sp., Symphytum tuberosum, Thamnobryum alopecurum, Thuidium tamariscinum; 15 (+) Atrichum undulatum, Plagiothecium neglectum, Veratrum album. 16 (+) Polytrichum formusum, Peltigera aphthosa.

Table 13. Omphalodo-Fagetum var. geogr. Calamintha grandiflora sambucetosum nigrae

1 (+) Cardamine bulbifera, Heracleum sphondylium, Plagiomnium undulatum; 2 (3) Vaccinium myrtillus; (+) Adenostyles glabra, Dicranum scoparium; 3 (1) Ulmus glabra; (+) Circaea lutetiana, Galeopsis speciosa, Hylocomium splendens, Lunaria rediviva, Petasites albus, Phyllitis scolopendrium, Polypodium vulgare, Ranunculus lanuginosus, Stellaria montana; 4 (+) Carex alba; 5 (+) Atropa bella-donna, Blechnum spicant, Cladonia furcata, Hacquetia epipactis, Hypericum hirsutum, Monotropa hypopitys, Scrophularia nodosa, Sorbus aria; 6 (+) Calamagrostis arundinacea, Cladonia digitata, Moehringia muscosa, Neckera complanata. 
Table 14. Omphalodo-Fagetum var. geogr. Calamintha grandiflora asaretosum europaei

1 (+) Melica nutans; (r) Gymnocarpium robertianum; 2 (+) Carex alba, Cardamine enneaphyllos, Euonymus latifolia, Helelborus niger, Laburnum alpinum, Lilium martagon, Melittis melissophyllum; 3 (+) Brachythecium velutinum, Carex pendula, Conocephalum conicum, Dryopteris dilatata, Euphorbia carniolica, Fissidens taxifolius, Fragaria vesca, Knautia drymeia, Ranunculus lanuginosus, Rosa arvensis, Thelypteris limbosperma; (r) Ilex aquifolium; 4 (+) Stachys alpina; (r) Quercus petraea; 5 (+) Bromus benekenii, Dicranum scoparium, Monotropa hypophegea, Neottia nidus-avis, Plagiochila porelloides, Thudium tamariscinum; (r) Betula pendula; 6 (+) Asplenium viride, Geranium robertianum, Heracleum sphondylium, Homalothecium philippeanum, Hypnum cupressiforme, Mnium thomsonii, Plagiochila asplenioides; 7 (+) Aegopodium podagraria, Anomodon attenuatus, Asplenium ruta-muraria, Lathraea squamaria, Moehringia trinervia, Plagiomnium cuspidatum, Polygonatum verticillatum; 8 (1) Stellaria montana; (+) Atrichum undulatum, Festuca altissima, Gymnocarpium dryopteris; (r) Tamus communis.

\subsection{TAXA OCGURING ONLY ONCE IN TABle 1}

Fagetalia sylvaticae: $\underline{8}$ - calamagrostietosum variae: Cephalanthera longifolia $12^{3,1}$, Peucedanum austriacum $6^{1,2}, \underline{2}$ - adenostyletosum glabrae: C. pilosa $11^{2,5}$, $\underline{5}$-festucetosum altissimae I: Cerastium sylvaticum $8^{1,8}, \underline{7}$ - stellarietosum: Anemone ranunculoides $5^{1,1}$, Cardamine flexuosa $5^{1,1}$, Corydalis cava $19^{6,9}$, C. solida $24^{6,3}, 11$ - asaretosum: Carpinus betulus 25,8, Carex pendula $13^{3,2}$, Ilex aquifolium $13^{1,6}$, Juglans regia $25^{4,8}$, Rosa arvensis $13^{3,2}$; Quercetalia pubescentis: $\underline{8}$ - calamagrostietosum variae: Euonymus verrucosa $6^{0,6}, \quad 4$-calamagrostietosum arundinaceae: Arabis hirsuta $3^{0,7}, \underline{7}$ - stellarietosum montanae: Hypericum montanum 102,1; Querco-Fagetea: 1 - rhododendretosum hirsuti: Ranunculus auricomus agg. $6^{1,4}$, $\underline{8}$ - calamagrostietosum variae: Hieracium lachenalii $6^{0,6}, \underline{7}$ - stellarietosum montanae: Vinca minor $14^{3,2}$, Gagea lutea $10^{2,1}$, Galanthus nivalis $5^{1,1}, 11$ - asaretosum: Corylus avellana 133,2; Erico-Pinetea: 1 - rhododendretosum hirsuti: Erica carnea $25^{6,3}$, Polygala chamaebuxus $6^{1,4}$, Rhodothamnus chamaecistus $6^{1,4}, \underline{8}$ - calamagrostietosum variae: Buphthalmum salicifolium $41^{8,6}$, Potentilla carniolica $6^{1,2}$, Aquilegia nigricans $6^{1,8}, 2$ - adenostyletosum glabrae: Carex ornithopoda $6^{0,6}, \underline{6}$ - festucetosum altissimae II: Pyrola minor $4^{0,8}$; Vaccinio-Piceetea: 1 - rhododendretosum hirsuti: Lonicera caerulea $50^{9,7}, \underline{3}$ - saxifragetosum cuneifoliae: Melampyrum sylvaticum $5^{1,1}, \underline{6}$-festucetosum altissimae II: Luzula luzulina $19^{4,5} ; 11$ - asaretosum: Larix decidua 25,3, Mulgedio-Aconitetea: 1 - rhododendretosum hirsuti: Salix glabra $19^{2,1}$, Sorbus chamaemespilus $44^{8,3}$, Pleurospermum austriacum $25^{5,6}$, Senecio nemorensis $6^{0,7}, \underline{2}$ - adenostyletosum glabrae: Adenostyles alliariae $11^{2,5}$, Senecio cacaliaster $11^{2,5}, \underline{7}$ - stellarietosum montanae: Hypericum maculatum $5^{1,1}$, Scrophularia vernalis $5^{1,1}$, Anthriscus nitida $1^{0,5}$; Elyno-Seslerietea: 1 - rhododendretosum hirsuti: Pinguicula alpina $13^{2,1}, \underline{8}$ - calamagrostietosum variae: Betonica alopecurus $6^{1,2}$, Laserpitium peuce-

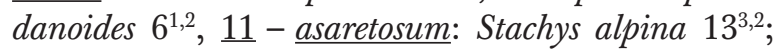
Asplenietea trichomanis: 1 - rhododendretosum hirsuti: Primula carniolica $31^{6,3}, \underline{2}$ - adenostyletosum glabrae: Valeriana montana $6^{1,2}$; Other species: 1 - rhododendretosum hirsuti: Dactylorhiza fuchsii $19^{4,2}, \underline{8}$ - calamagrostietosum variae: Carex humilis $6^{1,2}$, Clinopodium vulgare $12^{2,5}$, Vincetoxicum hirundinaria $18^{2,5}$, Verbascum lanatum $6^{1,3}, \underline{3}$ - saxifragetosum cuneifoliae: Spiraea chamaedryfolia $25^{6,1}, \underline{6}-$ festucetosum altissimae II: Galium mollugo $4^{0,8}, \underline{7}$ - stellarietosum montanae: Dactylis polygama $5^{1,1}$, Geum urbanum $5^{1,1}$, Stachys sylvatica $5^{1,1}, 11$ - asaretosum: Bromus benekenii $13^{3,2}$, Lathrea squamaria $13^{3,2}$; Lichens \& bryophytes: 1 - rhododendretosum hirsuti: Entodon schleicheri $81^{22,9}$, Cladonia sp. $69^{15,3}$, Peltigera leucophlebia $56^{12,5}$, Dicranum sp. 38, cata $44^{9,7}$, Ditrichium flexicaule $38^{8,3}$, Bryum capillare agg. $25^{5,6}$, Plagiothecium cavifolium 25, , Hookeria lucens $19^{4,2}$, Calypogeia trichomanis $13^{2,8}$, Dicranodontum denudatum $13^{2,8}$, Plagiothecium nemorale $13^{2,8}$, Scapania nemorea $13^{2,8}$, Collema sp. $13^{2,8}$, Campylium stellatum $6^{1,4}$, Cirriphyllum tenuinerve $6^{1,4}$, Distichium capillaceaum $6^{1,4}$, Leptogium saturninum $6^{1,4}$, Parmeliella tryptophylla $6^{1,4}$, Peltigera collina $6^{1,4}, \underline{3}$ - saxifragetosum cuneifoliae: Plagiothecium laetum 102,2, Bazzania trilobata $5^{1,1}$, Brachythecium erythrorhizon $5^{1,1}$, Bryum sp. 51,1, Calliergon sp. 51,1, Campylium halleri $5^{1,1}$, Cirriphyllum piliferum $5^{1,1}$, Hypnum sauteri $5^{1,1}$, Lepidozia reptans $5^{1,1}$, Leptobryum pyriforme $5^{1,1}$, Lescuraea saxicola $5^{1,1}$, Mnium ambiguum $5^{1,1}$, Odontoschisma denudatum $5^{1,1}$, Oncophorus virens $5^{1,1}$, Platygyrium repens $5^{1,1}$, Icmadophila ericetorum $5^{1,1}$, 2 - adenostyletosum glabrae: Homalothecium lutescens $6^{1,2}, \underline{9}$ - seslerietosum autumnalis: Plagiothecium neglectum $6^{1,4}, \underline{6}$-festucetosum altissimae II: Cladonia rangiferina $7^{1,6}$, Antitrichia curtipendula $4^{0,8}, \underline{7}$ - stellarietosum montanae: Plagiomnium affine $14^{3,2}$, Porella platyphylla $10^{2,1}$, Brachythecium glareosum $5^{1,1}$, Brachythecium sp. $5^{1,1}, 11$ - asaretosum: Anomodon attenuatus $13^{3,2}$, Brachythecium velutinum $13^{3,2}$. 


\subsection{List OF LOCALITIES: corresponding} number in the table, relevé No., coordinates (in Gauss-Krügger projection), coverage: A - tree layer, B - shrub layer, C - herb layer, D - moss layer, $\mathrm{S}$ - stoniness

Table 5. Omphalodo-Fagetum var. geogr. Saxifraga cuneifolia adenostyletosum glabrae

Forest reserve Bukov vrh (Trnovo): 1 (131135) $45,992^{\circ} \mathrm{N} 13,890^{\circ} \mathrm{E}$; alt. 1270 , exp. N, incl. $30^{\circ}$; A $90 \%$, B 10\%, C 50\%, D 10\%, S 60\%; 27.5.1999,

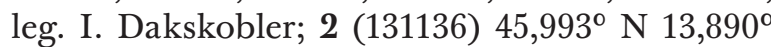
E; alt. 1250 , exp. N, incl. $25^{\circ}$; A $90 \%$, B $10 \%$, C $60 \%$, D 20\%, S 50\%; 3.7.2000, leg. I. Dakskobler; 3 (131137) $45,990^{\circ} \mathrm{N} 13,888^{\circ} \mathrm{E}$; alt. 1260, exp. SW, incl. $25^{\circ}$; A $90 \%$, B $20 \%$, C 50\%, D $10 \%$, S 30\%; 3.7.2000, leg. I. Dakskobler; 4 (131138) $45,990^{\circ} \mathrm{N}$ $13,891^{\circ}$ E; alt. 1240 , exp. SE, incl. $20^{\circ}$; A $80 \%$, B 40\%, C 50\%, D 10\%, S 20\%; 3.7.2000, leg. I. Dak-

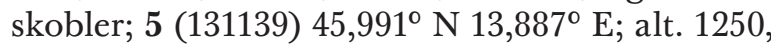
exp. SW, incl. $20^{\circ}$; A $90 \%$, B $15 \%$, C $50 \%$, D $10 \%$, S 30\%; 3.7.2000, leg. I. Dakskobler; 6 (131140) $45,990^{\circ} \mathrm{N} 13,890^{\circ} \mathrm{E}$; alt. 1270 , exp. N, incl. $30^{\circ}$; A $80 \%$, B $1 \%$, C 70\%, D 5\%, S 40\%; 3.7.2000, leg. I. Dakskobler; 7 (202783) 46,989 $\mathrm{N} 13,886^{\circ} \mathrm{W}$; alt. 1280 , exp. W, incl. $40^{\circ}$; A $80 \%$, B $10 \%$, C $60 \%$, D 10\% S 50\%; 5.6.2000, leg. I. Dakskobler; 8 (230619) $45,991^{\circ} \mathrm{N} 13,885^{\circ} \mathrm{W}$; alt. 1250 , exp. SE, incl. $10^{\circ}$; A $80 \%$, B 5\%, C 70\%, D 10\%, S 20\%; 19.6.2002, leg. I. Dakskobler; 9 (230620) 45,992 ${ }^{\circ}$ N 13,888 W; alt. 1280, exp. SW, incl. 35 ; A 80\%, B 10\%, C 50\%, D 20\%, S 50\%; 19.6.2002, leg. I. Dakskobler;

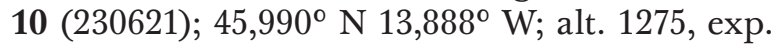
W, incl. $25^{\circ}$; A $90 \%$, B 5\%, C 60\%, D 10\%, S 20\%; 19.6.2002, leg. I. Dakskobler; 11 (230623) 45,991 $\mathrm{N} 13,888^{\circ} \mathrm{W}$; alt. 1270 , exp. SW, incl. $40^{\circ}$; A $80 \%$, B 10\%, C 60\%, D 20\%, S 60\%; 19.6.2002, leg. I.

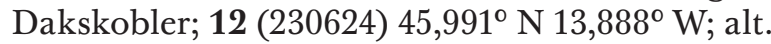
1250, exp. /, incl. /; A 60\%, B 60\%, C 40\%, D 10\%, S 20\%; 19.6.2002, leg. I. Dakskobler; 13 (230625) $45,990^{\circ} \mathrm{N} 13,887^{\circ} \mathrm{W}$; alt. 1240 , exp. SW, incl. $25^{\circ}$; A $70 \%$, B $60 \%$, C 50\%, D 10\%, S 10\%; 19.6.2002, leg. I. Dakskobler; 14 (230626) 45,990 N 13,889 W; alt. 1280, exp. /, incl. /; A 90\%, B 10\%, C 60\%, D 5\%, S 10\%; 19.6.2002, leg. I. Dakskobler; 15 (230627) $45,989^{\circ} \mathrm{N} 13,889^{\circ} \mathrm{W}$; alt. 1280, exp. NW, incl. $25^{\circ}$; A $80 \%$, B 30\%, C $60 \%$, D 10\%, S 20\%; 19.6.2002, leg. I. Dakskobler; 16 (230629) $45,989^{\circ} \mathrm{N} 13,888^{\circ} \mathrm{W}$; alt. 1260 , exp. N, incl. $25^{\circ}$; A $90 \%$, B 5\%, C 60\%, D 10\%, S 30\%; 19.6.2002, leg. I. Dakskobler; 17 (230630) 45,989 ${ }^{\circ}$ N 13,887 ${ }^{\circ} \mathrm{W}$; alt. 1280 , exp. N, incl. $30^{\circ}$; A $90 \%$, B $5 \%$, C $60 \%$, D 20\%, S 40\%; 19.6.2002, leg. I. Dakskobler; 18

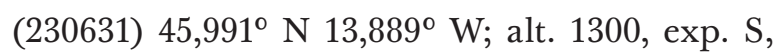
incl. $20^{\circ}$; A $90 \%$, B $5 \%$, C 50\%, D $10 \%$, S 30\%; 19.6.2002, leg. I. Dakskobler.

Table 6. Omphalodo-Fagetum var. geogr. Saxifraga cuneifolia saxifragetosum cuneifoliae

1 (10111) Predmeja, Cingolca, 45.946 $\mathrm{N}$ $13.851^{\circ} \mathrm{E}$; alt. $1170 \mathrm{~m}$ a.s.l., exp. $\mathrm{NE}$, incl. $50^{\circ}$; A 70\%, B 50\%, C 70\%, D 30\%, S 50\%; 7.7.2000, leg. B. Surina.; 2 (10112) Predmeja, $45.960^{\circ} \mathrm{N} 13.889^{\circ}$ E; alt. 1060 m, exp. NW, incl. 40% A 60\%, B 40\%, C 70\%, D 40\%, S 70\%; 7.7.2000, leg. B. Surina. 3 (10113) Predmeja, Ojstrovica, SE from the peak; $45,997^{\circ} \mathrm{N} 13,831^{\circ} \mathrm{E}$; alt. 1280 , exp. E, incl. $50^{\circ}$; A $70 \%$, B 20\%, C 70\%, D 20\%, S 60\%; 8.7.2000, leg. B. Surina; 4 (10114) Predmeja, between Veliki Bukovec peak and Paradana above the road Turški klanec-Paradana (Ledenica); $45,990^{\circ} \mathrm{N}$ $13,838^{\circ} \mathrm{E}$; alt. 1250 , exp. SSE, incl. $30^{\circ}$; A $70 \%$, B 30\%, C 70\%, D 20\%, S 60\%; 8.7.2000, leg. B. Surina; 5 (10115) Predmeja, Škrbina, by the path Škrbina-Golaki; $45,981^{\circ} \mathrm{N} 13,891^{\circ} \mathrm{E}$; alt. 1250 , exp. NW, incl. $30^{\circ}$; A $80 \%$, B 20\%, C $80 \%$, D 20\%, S 30\%; 22.6.2000, leg. B. Surina; 6 (10116)

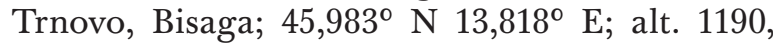
exp. E, incl. $20^{\circ}$; A $60 \%$, B 50\%, C $80 \%$, D 20\%, S 20\%; 26.7.2000, leg. B. Surina; 7 (10117) Orlevc, Tisovec; $45,961^{\circ} \mathrm{N} 13,932^{\circ} \mathrm{E}$; alt. 1040, exp. SW, incl. $20^{\circ}$; A $70 \%$, B 40\%, C 80\%, D 10\%, S 30\%; 20.7.2000, leg. B. Surina; 8 (10118) Trnovo, Bisaga; $45,981^{\circ} \mathrm{N} 13,819^{\circ} \mathrm{E}$; alt. 1270 , exp. N, incl. $45^{\circ}$; A 70\%, B 60\%, C 70\%, D 30\%, S 70\%; 26.7.2000, leg. B. Surina; 9 (10119) Predmeja, rocky slope above Mala Lazna between Turški klanec and Paradana (Ledenica); $45,988^{\circ} \mathrm{N} 13,836^{\circ} \mathrm{E}$; alt. 1230, exp. E, incl. $40^{\circ}$; A $60 \%$, B 40\%, C 70\%, D 10\%, S 70\%; 8.7.2000, leg. B. Surina; 10 (10120) Trnovo, Petelinovec; $45,980^{\circ} \mathrm{N} 13,803^{\circ} \mathrm{E}$; alt. 1200 , exp. NNE, incl. $40^{\circ}$; A $80 \%$, B $20 \%$, C $80 \%$, D $10 \%$, S 20\%; 31.5.2000, leg. B. Surina; 11 (10121) Trnovo,

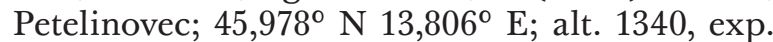
$\mathrm{N}$, incl. $40^{\circ}$; A $100 \%$, B 5\%, C 80\%, D 10\%, S 20\%; 31.5.2000, leg. B. Surina; 12 (10122) Trnovo, between peaks Kališevi hrib, Petelinovec and Bat; $45,978^{\circ} \mathrm{N} 13,797^{\circ} \mathrm{E}$; alt. 1135 , exp. NE, incl. $40^{\circ}$; A $80 \%$, B $10 \%$, C $70 \%$, D 10\%, S 30\%; 31.5.2000, leg. B. Surina; 13 (10123) Trnovo, forest reserve Kališev hrib; $45,982^{\circ} \mathrm{N} 13,790^{\circ} \mathrm{E}$; alt. 1035, exp. NNE, incl. $25^{\circ}$; A $80 \%$, B $10 \%$, C 70\%, D $10 \%$, S 30\%; 30.5.2000, leg. B. Surina; 14 (10124) Trnovo, forest reserve Kališev hrib; $45,980^{\circ} \mathrm{N} 13,790^{\circ} \mathrm{E}$; alt. 1075, exp. NE, incl. 25; A 100\%, B 10\%, C 80\%, D 10\%, S 30\%; 1.6.2000, leg. B. Surina; 15 
(10150); Predmeja, Škrbina; 45,985 N 13,891 E; alt. 1210, exp. NNW, incl. $25^{\circ}$; A 90\%, B 20\%, C 90\%, D 10\%, S 30\%; 22.6.2000, leg. B. Surina; 16 (10151) Predmeja, Škrbina; 45,987 ${ }^{\circ} \mathrm{N} 13,888^{\circ} \mathrm{E}$; alt. 1230, exp. /, incl. /; A 100\%, B 20\%, C 100\%, D 1\%, S 10\%; 22.6.2000, leg. B. Surina; 17 (10153)

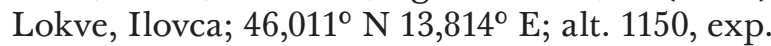
NE, incl. $45^{\circ}$; A $100 \%$, B 10\%, C $70 \%$, D 10\%, S 30\%; 20.6.2000, leg. B. Surina; 18 (10154); Predmeja, above Avška Lazna; $45,974^{\circ} \mathrm{N} 13,816^{\circ} \mathrm{E}$; alt. 1245 , exp. NE, incl. $45^{\circ}$; A $100 \%$, B $10 \%$, C $80 \%$, D 50\%, S 20\%; 30.5.2000, leg. B. Surina; 19 (22813) Trnovo; alt. 1140, exp. NE, incl. $35^{\circ}$; A $80 \%$, B 20\%, C $80 \%$, D 5\%, S 30\%; June 1979, leg. I. Puncer; 20 (22814) Trnovo; alt. 1150, exp. N, incl. $40^{\circ}$; A $80 \%$, B $20 \%$, C $70 \%$, D $10 \%$, S $30 \%$; June 1979, leg. I. Puncer.

Table 7. Omphalodo-Fagetum var. geogr. Saxifraga cuneifolia calamagrostietosum arundinaceae

1 (10125) Predmeja, Polomov rajda; $45,956^{\circ} \mathrm{N}$ $13,860^{\circ} \mathrm{E}$; alt. 1020 , exp. NNE, incl. $25^{\circ}$; A $100 \%$, B 30\%, C 40\%, D 10\% S 30\%; 26.6.2000, leg. B. Surina; 2 (10136) Predmeja, Pri studencu, near Golobova jama; $45,949^{\circ} \mathrm{N} 13,812^{\circ} \mathrm{E}$; alt. 1210 , exp. SSW, incl. $25^{\circ}$; A $70 \%$, B $20 \%$, C $70 \%$, D $10 \%$ S 50\%; 30.6.2000, leg. B. Surina; 3 (10137) Predmeja, Strgarija, Prevalski vrh; $45,961^{\circ} \mathrm{N} 13,796^{\circ}$ E; alt. 1120 , exp. SW, incl. $50^{\circ}$; A $70 \%$, B $20 \%$, C 70\%, D 10\%, S 30\%; 4.7.2000, leg. B. Surina; 4 (10139) Lokvem Škol, NW from the peak; 46,025 $\mathrm{N} 13,800^{\circ} \mathrm{E}$; alt. 945 , exp. E, incl. $20^{\circ}$; A $100 \%$, B 10\%, C 70\%, D 10\%, S 30\%; 9.6.2000, leg. B. Surina; 5 (10140) Lokve, Robotna, between peaks Mali Češevik and Jančerijski vrh; $46,025^{\circ}$

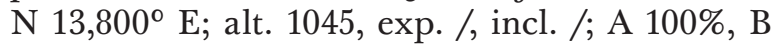
10\%, C 80\%, D 10\%, S 20\%; 9.6.2000, leg. B. Surina; 6 (10141) Predmeja, Vrh dolin; 45,970 ${ }^{\circ} \mathrm{N}$ $13,820^{\circ} \mathrm{E}$; alt. 1130 , exp. SSE, incl. $15^{\circ}$; A $90 \%$, B 20\%, C 90\%, D 10\%, S 20\%; 4.7.2000, leg. B. Surina; 7 (10142) Predmeja, Vrh dolin; 45,969 ${ }^{\circ} \mathrm{N}$ $13,800^{\circ} \mathrm{E}$; alt. 1210 , exp. S, incl. $15^{\circ}$; A $90 \%$, B 30\%, C 90\%, D 10\%, S 30\%; 4.7.2000, leg. B. Surina; 8 (10143) Predmeja, Polomova rajda towards Mala Lazna; $45,958^{\circ} \mathrm{N} 13,859^{\circ} \mathrm{E}$; alt. 980, exp. NNE, incl. $20^{\circ}$; A $90 \%$, B $30 \%$, C $70 \%$, D 20\%, S 20\%; 26.6.2000, leg. B. Surina; 9 (10144) Predmeja, Petrov hrib, plateau; $45,966^{\circ} \mathrm{N} 13,858^{\circ} \mathrm{E}$; alt. 1070, exp. E, incl. $5^{\circ}$; A 90\%, B 20\%, C 80\%, D 10\%, S 30\%; 27.6.2000, leg. B. Surina; 10 (10145) Predmeja, Nemški hrib; 45,971 ${ }^{\circ} \mathrm{N} 13,853^{\circ} \mathrm{E}$; alt. 1130, exp. E, incl. $25^{\circ}$; A $90 \%$, B $20 \%$, C $80 \%$, D
10\%, S 30\%; 28.6.2000, leg. B. Surina; 11 (10146) Predmeja, Petrov hrib; $45,962^{\circ} \mathrm{N} 13,855^{\circ} \mathrm{E}$; alt. 1060, exp. SE, incl. $15^{\circ}$; A 80\%, B 20\%, C 40\%, D 20\%, S 70\%; 28.6.2000, leg. B. Surina; 12 (10147) Predmeja, Bevške jame; $45,963^{\circ} \mathrm{N} 13,840^{\circ} \mathrm{E}$; alt. 1010, exp. SW, incl. $15^{\circ}$; A 80\%, B 30\%, C 70\%, D 20\%, S 30\%; 29.6.2000, leg. B. Surina; 13 (10148) Predmeja, Rusa pot, plateau; $45,964^{\circ} \mathrm{N} 13,864^{\circ} \mathrm{E}$; alt. 1030, exp. /, incl. /; A 80\%, B 30\%, C 80\%, D 10\%, S 20\%; 27.6.2000, leg. B. Surina; 14 (10149) Predmeja, Pri jelcah towards Kozarnice; $45,963^{\circ}$

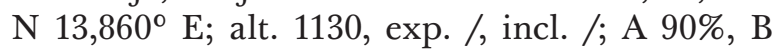
$70 \%$, C 70\%, D 40\%, S 60\%; 27.6.2000, leg. B. Surina; 15 (10152) Predmeja, beneath Ruske barake; $45,953^{\circ} \mathrm{N} 13,865^{\circ} \mathrm{E}$; alt. 980 , exp. SE, incl. $20^{\circ}$; A $100 \%$, B 20\%, C 50\%, D 10\%, S 1\%; 26.6.2000, leg. B. Surina; 16 (10155) Predmeja, Strgarija, S from Prevalski vrh, between Smrečje and Črni vrh;

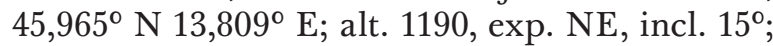
A $80 \%$, B 30\%, C 70\%, D 10\%, S 20\%; 4.7.2000, leg. B. Surina; 17 (10156) Lokve, between Ojstrovica and Snežna jama; $45,999^{\circ} \mathrm{N} 13,816^{\circ} \mathrm{E}$; alt. 1180 , exp. S, incl. $20^{\circ}$; A $80 \%$, B $10 \%$, C 70\%, D 30\%, S 50\%; 20.6.2000, leg. B. Surina; 18 (10157) Predmeja, Mali Golak, SW from the peak; $45,975^{\circ} \mathrm{N}$ $13,865^{\circ} \mathrm{E}$; alt. 1245 , exp. SW, incl. $30^{\circ}$; A $100 \%$, B 20\%, C 70\%, D 20\%, S 50\%; 22.6.2000, leg. B. Surina; 19 (10158) Predmeja, Mali Golak, Paradana;

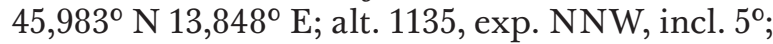
A $100 \%$, B $10 \%$, C $80 \%$, D 20\%, S 40\%; 23.6.2000, leg. B. Surina; 20 (10159) Predmeja, Kozarnice; $45,971^{\circ} \mathrm{N} 13,863^{\circ} \mathrm{E}$; alt. 1080 , exp. S, incl. $10^{\circ}$; A 80\%, B 30\%, C 80\%, D 20\%, S 40\%; 27.6.2000, leg. B. Surina; 21 (10160) Lokve, between Snežna jama and Ojstrovica; $45,005^{\circ} \mathrm{N} 13,816^{\circ} \mathrm{E}$; alt. 1160 , exp. SW, incl. $45^{\circ}$; A $70 \%$, B $20 \%$, C 40\%, D $10 \%$, S 60\%; 20.6.2000, leg. B. Surina; 22 (10173) Predmeja, Smrečje, Mali Črmenjak; 45,955 ${ }^{\circ} \mathrm{N} 13,828^{\circ}$ E; alt. 1240 , exp. S, incl. $20^{\circ}$; A $90 \%$, B $10 \%$, C 70\%, D 10\%, S 30\%; 6.7.2000, leg. B. Surina; 23 (10175) Predmeja, plateau between Bevške jame

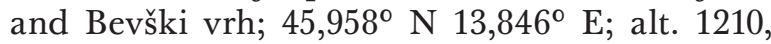
exp. /, incl. /; A 90\%, B 30\%, C 70\%, D 20\%, S 30\%; 29.6.2000, leg. B. Surina; 24 (10176) Predmeja, Pri studencu; $45,948^{\circ} \mathrm{N} 13,817^{\circ} \mathrm{E}$; alt. 1090 , exp. SW, incl. $40^{\circ}$; A $90 \%$, B $10 \%$, C $70 \%$, D $10 \%$, S 30\%; 30.6.2000, leg. B. Surina; 25 (10177) Predmeja, Selovec, Gojaške jame; 45,941 ${ }^{\circ} \mathrm{N} 13,809^{\circ}$ E; alt. 1150 , exp. NE, incl. $20^{\circ}$; A $70 \%$, B 30\%, C 70\%, D 20\%, S 40\%; 5.7.2000, leg. B. Surina; 26 (10178) Predmeja, Čaven, Za Gracem; 45,938 $\mathrm{N}$ $13,800^{\circ} \mathrm{E}$; alt. 1100 , exp. N, incl. $30^{\circ}$; A $70 \%$, B 20\%, C 80\%, D 20\%, S 40\%; 5.7.2000, leg. B. Suri- 
na; 27 (10179) Predmeja, Njivica, Kucelj; 45,942 $\mathrm{N} 13,796^{\circ} \mathrm{E}$; alt. 1160 , exp. /, incl. /; A $80 \%$, B 10\%, C 90\%, D 5\%, S 5\%; 5.7.2000, leg. B. Surina; 28 (10180) Predmeja, Njivice, Krnica; 45,946 ${ }^{\circ} \mathrm{N}$ $13,794^{\circ} \mathrm{E}$; alt. 1030 , exp. W, incl. $20^{\circ}$; A $90 \%$, B 20\%, C 90\%, D 5\%, S 5\%; 5.7.2000, leg. B. Surina; 29 (10182) Predmeja, Rusa pot; 45,959 $\mathrm{N} 13,863^{\circ}$ E; alt. 990, exp. SE, incl. $15^{\circ}$; A $80 \%$, B $30 \%$, C 80\%, D 10\%, S 30\%; 27.6.2000, leg. B. Surina; 30 (10183) Predmeja, Petrov hrib; 46,008 ${ }^{\circ}$ N 13,849 ${ }^{\circ}$ E; alt. 1095 , exp. SE, incl. $50^{\circ}$; A $70 \%$, B $40 \%$, C $40 \%$, D 40\%, S 80\%; 29.6.2000, leg. B. Surina; 31 (10185) Predmeja, Njivice, between peaks

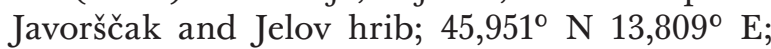
alt. 1150 , exp. N, incl. $5^{\circ}$; A $80 \%$, B 5\%, C 80\%, D 20\%, S 30\%; 30.6.2000, leg. B. Surina; 32 (10186) Predmeja, Smrečjem Mali Črmenjak, Pod vratci; $45,955^{\circ} \mathrm{N} 13,822^{\circ} \mathrm{E}$; alt. 1140 , exp. E, incl. $20^{\circ}$; A $80 \%$, B $10 \%$, C $60 \%$, D 10\%, S 30\%; 6.7.2000, leg. B. Surina; 33 (10187) Predmeja, between Cingolca, Veliki Črmenjak and Požgane jame; 45,947 N 13,847 ${ }^{\circ}$ E; alt. 1230 , exp. SW, incl. $20^{\circ}$; A 90\%, B 20\%, C 60\%, D 20\%, S 60\%; 7.7.2000, leg. B. Surina; 34 (10194) Predmeja; 45,962 ${ }^{\circ}$ N 13,887 E; alt. 1140 , exp. SW, incl. $15^{\circ}$; A $90 \%$, B 40\%, C 40\%, D 10\%, S 30\%; 7.7.2000, leg. B. Surina.

\section{Table 8. Omphalodo-Fagetum var. geogr. Saxifraga cuneifolia festucetosum altissimae I}

1 (10126) Trnovo, Nemci; 46,005 ${ }^{\circ} \mathrm{N} \mathrm{13,775^{ \circ }}$ SE; alt. 910, exp. SE, incl. $15^{\circ}$; A $80 \%$, B $20 \%$, C 80\%, D 40\%, S 30\%; 24.5.2000, leg. B. Surina; 2 (10161) Trnovo, Lokve, Poncala, Na Bajti; 45,999

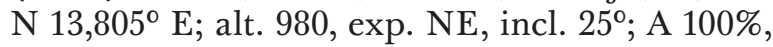
B 10\%, C 80\%, D 20\%, S 20\%; 21.6.2000, leg. B. Surina; 3 (10172) Trnovo, Lokve, Ojstrovica, NW flank; 45,994 ${ }^{\circ} \mathrm{N} 13,819^{\circ} \mathrm{E}$; alt. 1160 , exp. W, incl. $20^{\circ}$; A $100 \%$, B 5\%, C 80\%, D 1\%, S 5\%; 20.6.2000, leg. B. Surina; 4 (10174) Trnovo, Smrečje, rocky slope above Gospodova senožet; $45,959^{\circ} \mathrm{N}$ $13,828^{\circ} \mathrm{E}$; alt. 1210 , exp. N, incl. $30^{\circ}$; A $80 \%$, B 50\%, C 70\%, D 5\%, S 20\%; 6.7.2000, leg. B. Surina; 5 (10201) Trnovo, Nemci, Brezov hrib, slope; $46,002^{\circ} \mathrm{N} 13,788^{\circ} \mathrm{E}$; alt. 915 , exp. NNE, incl. $20^{\circ}$; A $100 \%$, B 5\%, C 70\%, D 5\%, S 10\%; 8.6.2000, leg. B. Surina; 6 (10202) Trnovo, Nemci, Brezov hrib, plateau; $46,002^{\circ} \mathrm{N} 13,786^{\circ} \mathrm{E}$; alt. 900, exp. /, incl. /; A 100\%, B 20\%, C 70\%, D 20\%, S 30\%; 8.6.2000, leg. B. Surina; 7 (10203) Trnovo, Nemci, Šibrove doline; $46,005^{\circ} \mathrm{N} 13,785^{\circ} \mathrm{E}$; alt. 915 , exp. $\mathrm{N}$, incl. $5^{\circ}$; A $80 \%$, B 20\%, C 100\%, D 1\%, S 1\%; 8.6.2000, leg. B. Surina; 8 (10124) Trnovo, Kališev hrib, Forest reserve Kališev hrib; $45,980^{\circ} \mathrm{N} 13,790^{\circ}$
E; alt. 1075, exp. NE, incl. 25; A 100\%, B 10\%, C $80 \%$, D 10\%, S 30\%; 1.6.2000, leg. B. Surina; 9 (10169) Trnovo, Lokve, Poncala, Na Bajti; 45,995 N 13,805 ${ }^{\circ}$ E; alt. 1010 , exp. SW, incl. 5 ${ }^{\circ}$; A $100 \%$, C 90\%, D 1\%, S 1\%; 21.6.2000, leg. B. Surina; 10 (10170) Trnovo, Lokve, Poncala, Na Bajti; 45,996 $\mathrm{N} 13,808^{\circ} \mathrm{E}$; alt. 990 , exp. SW, incl. $30^{\circ}$; A $100 \%$, B 1\%, C $60 \%$, D 10\%, S 20\%; 21.6.2000, leg. B. Surina; 11 (10198) Trnovo, Jelov hrib; 45,980 $\mathrm{N} 13,774^{\circ} \mathrm{E}$; alt. 865 , exp. W, incl. $25^{\circ}$; A $100 \%$, C $30 \%$, D $10 \%$, S 30\%; 1.6.2000, leg. B. Surina; 12 (10205) Trnovo, Mrzovec; 45,984ㅇ N 13,806 ${ }^{\circ}$ E; alt. 1180 , exp. W, incl. $40^{\circ}$; A $100 \%$, B $10 \%$, C 50\%, D 30\%, S 50\%; 31.5.2000, leg. B. Surina; 13 (10206) Trnovo, Kolovrat, doline; $45,958^{\circ} \mathrm{N}$ $13,778^{\circ}$ E; alt. 945 , exp. /, incl. /; A 70\%, B 10\%, C 50\%, D 40\%, S 50\%; 2.6.2000, leg. B. Surina; 14 (10195) Trnovo, Nemci, Na Dolinah; 46,005 ${ }^{\circ} \mathrm{N}$ $13,761^{\circ} \mathrm{E}$; alt. 850 , exp. SW, incl. $15^{\circ}$; A $100 \%$, C 70\%, D 10\%, S 30\%; 25.5.2000, leg. B. Surina; 15 (10196) Trnovo, Nemci, between Nemci and Dolina; $46,001^{\circ} \mathrm{N} 13,726^{\circ} \mathrm{E}$; alt. 820, exp. SW, incl. $20^{\circ}$; A $80 \%$, B 5\%, C 50\%, D 30\%, S 50\%; 7.6.2000, leg. B. Surina; 16 (10199) Trnovo, Vratarski hrib, $\mathrm{S}$ from the summit; $45,995^{\circ} \mathrm{N} 13,764^{\circ} \mathrm{E}$; alt. 790 , exp. S, incl. $5^{\circ}$; A $80 \%$, B $10 \%$, C 40\%, D 30\%, S 30\%; 7.6.2000, leg. B. Surina; 17 (10200) Trnovo, Nemci; $45,989^{\circ} \mathrm{N} 13,779^{\circ} \mathrm{E}$; alt. 865, exp. S, incl. $5^{\circ}$; A $80 \%$, B 30\%, C 100\%, D 1\%, S 5\%; 8.6.2000, leg. B. Surina; 18 (10162) Predmeja, Mali Golak, Strgarija, below the Preval; $45,974^{\circ} \mathrm{N} 13,857^{\circ} \mathrm{E}$; alt. 1275 , exp. SE, incl. $15^{\circ}$; A $100 \%$, B $30 \%$, C 100\%, D 1\%, S 1\%; 23.6.2000, leg. B. Surina; 19 (10163) Predmeja, between Kališe and Rusa pot; $45,961^{\circ} \mathrm{N} 13,867^{\circ} \mathrm{E}$; alt. 1050 , exp. W, incl. $15^{\circ}$; A $90 \%$, B 1\%, C 80\%, D 1\%, S 1\%; 28.6.2000, leg. B. Surina; 20 (10164) Trnovo, Lokve, Mojski vrh, small doline between Mojski vrh and Velika Ilovca; $46,004^{\circ} \mathrm{N} 13,818^{\circ} \mathrm{E}$; alt. 1125 , exp. /, incl. /; A $90 \%$, B 10\%, C 70\%, D 10\%, S 30\%; 20.6.2000, leg. B. Surina; 21 (10165) Predmeja, Mali Golak, Strgarijski vrh, preval Strgarija; $45,976^{\circ} \mathrm{N} 13,854^{\circ} \mathrm{E}$; alt. 1217, exp. N, incl. $25^{\circ}$; A 100\%, B 20\%, C 80\%, D 1\%, S 5\%; 22.6.2000, leg. B. Surina; 22 (10166) Trnovo, Petelinovec; $45,983^{\circ} \mathrm{N} 13,804^{\circ} \mathrm{E}$; alt. 1130, exp. /, incl. /; A 80\%, B 10\%, C 40\%, D 30\%, S 60\%; 31.5.2000, leg. B. Surina; 23 (10167) Predmeja, Mali Golak, Paradana; 45,980 $\mathrm{N} 13,851^{\circ} \mathrm{E}$; alt. 1270 , exp. NW, incl. $30^{\circ}$; A $90 \%$, B $10 \%$, C 40\%, D 30\%, S 60\%; 23.6.2000, leg. B. Surina; 24 (10168) Trnovo, Smrečje, Prevalski hrib; 45,957 $\mathrm{N} 13,810^{\circ} \mathrm{E}$; alt. 1070 , exp. N, incl. $15^{\circ}$; A $100 \%$, B 20\%, C 70\%, D 20\%, S 50\%; 6.7.2000, leg. B. 
Surina; 25 (10171) Predmeja, Nagnovec; 45,968 $\mathrm{N} 13,838^{\circ} \mathrm{E}$; alt. 1040 , exp. SE, incl. $20^{\circ}$; A $80 \%$, B 10\%, C 30\%, D 50\%, S 70\%; 29.6.2000, leg. B. Surina.

Table 9. Omphalodo-Fagetum var. geogr. Saxifraga cuneifolia festucetosum altissimae 2

1 (10127) Trnovo, Vratarski hrib; 45,992 ${ }^{\circ} \mathrm{N}$ $13,760^{\circ} \mathrm{E}$; alt. 810, exp. /, incl. /; A 70\%, B 20\%, C 40\%, D 40\%, S 70\%; 7.6.2000, leg. B. Surina; 2 (22794) Trnovo, Nemci; alt. 860, exp. NW, incl. $10^{\circ}$; A 70\%, B 10\%, C 90\%, D 40\%, S 70\%; August 1979; leg. I. Puncer; 3 (22795) Trnovo, Nemci; alt. 850, exp. NW, incl. $10^{\circ}$; A $80 \%$, B $20 \%$, C $60 \%$, D 40\%, S 50\%; August 1979; leg. I. Puncer; 4 (22798) Trnovo, Nemci; alt. 880, exp. NW, incl. $30^{\circ}$; A 90\%, B 20\%, C 30\%, D 60\%, S 80\%; August 1979; leg. I. Puncer; 5 (10181) Predmeja, Rusa pot; $45,959^{\circ} \mathrm{N} 13,863^{\circ} \mathrm{E}$; alt. 990 , exp. SE, incl. $15^{\circ}$; A $80 \%$, B $30 \%$, C $80 \%$, D $10 \%$, S $60 \% ; 27.6 .2000$, leg. B. Surina; 6 (10184) Predmeja, Bevške jame; $45,963^{\circ} \mathrm{N} 13,845^{\circ} \mathrm{E}$; alt. 1150 , exp. SSW, incl. $30^{\circ}$; A $90 \%$, B $40 \%$, C $50 \%$, D 20\%, S 70\%; 29.6.2000, leg. B. Surina; 7 (22785) Trnovo, Nemci; alt. 850, exp. N, incl. $5^{\circ}$; A 90\%, C 40\%, D 5\%, S 5\%; August 1979; leg. I. Puncer; 8 (22809) Predmeja; alt. 1050, exp. E, incl. 5; A 90\%, B 5\%, C 40\%, D 5\%, S 10\%; August 1979; leg. I. Puncer; 9 (22796) Trnovo, Lokve; alt. 1150, exp. W, incl. 30; A 90\%, B 5\%, C 60\%, D 10\%, S 50\%; July 1979; leg. I. Puncer; 10 (22797) Trnovo, Lokve; alt. 1030, exp. N, incl. $20^{\circ}$; A $80 \%$, B 10\%, C 50\%, D 20\%, S 60\%; July 1979; leg. I. Puncer; 11 (224115) Predmeja, Voglarji, Zavrh; $46,006^{\circ} \mathrm{N} 13,748^{\circ} \mathrm{E}$; alt. 790, exp. W, incl. $20^{\circ}$; A $80 \%$, B 5\%, C 60\%, D 30\%, S 30\%; 15.6.2010; leg. I. Dakskobler; 12 (22800) Predmeja; alt. 1080, exp. SW, incl. $10^{\circ}$; A 80\%, B 5\%, C 60\%, D 30\%, S 60\%; August 1979; leg. I. Puncer; 13 (22803) Predmeja; alt. 1020, exp. SE, incl. $10^{\circ}$; A $90 \%$, B 5\%, C 50\%, D 20\%, S 50\%; August 1979; leg. I. Puncer; 14 (22805) Predmeja; alt. 1040, exp. $\mathrm{S}$, incl. $10^{\circ}$; A $90 \%$, B 5\%, C $60 \%$, D 20\%, S 60\%; August 1979; leg. I. Puncer; 15 (22806) Predmeja; alt. 1070 , exp. S, incl. $5^{\circ}$; A $80 \%$, C 50\%, D 30\%, S 70\%; August 1979; leg. I. Puncer; 16 (22801) Predmeja; alt. 1070, exp. S, incl. $10^{\circ}$; A $70 \%$, B 10\%, C 50\%, D 40\%, S 70\%; August 1979; leg. I. Puncer; 17 (22802) Predmeja; alt. 1050, exp. S, incl. $5^{\circ}$; A $80 \%$, B $10 \%$, C $60 \%$, D 40\%, S 60\%; August 1979; leg. I. Puncer; 18 (22786) Trnovo, Nemci; alt. 860, exp. S, incl. 5 ; A 90\%, B 10\%, C 50\%, D 5\%, S 10\%; August 1979; leg. I. Puncer; 19 (22787) Predmeja; alt. 1080, exp. NW, incl. 5;
A 70\%, B 10\%, C 50\%, S 5\%; June 1979; leg. I. Puncer; 20 (22791) Trnovo; alt. 1000, exp. NW, incl. 5; A 90\%, B 5\%, C 90\%, D 5\%; July 1979; leg. I. Puncer; 21 (22792) Trnovo; alt. 1030, exp. SW, incl. 5\%; A $80 \%$, B 10\%, C 90\%, D 10\%, S 5\%; July 1979; leg. I. Puncer; 22 (22793) Predmeja; alt. 1220, exp. NE, incl. $10^{\circ}$; A 80\%, B 10\%, C 90\%, S 10\%; June 1979; leg. I. Puncer; 23 (22808) Predmeja; alt. 1200 , exp. NE, incl. $5^{\circ}$; A $80 \%$, C 70\%, D 5\%, S 10\%; June 1979; leg. I. Puncer; 24 (22799) Predmeja; alt. 1060, exp. S, incl. 5 ; A 80\%, B 10\%, C 80\%, D 10\%, S 10\%; August 1979; leg. I. Puncer; 25 (22810) Predmeja; alt. 1060, exp. S, incl. 5 ; 90\%, B 10\%, C 50\%, D 10\%, S 10\%; August 1979; leg. I. Puncer; 26 (22811) Predmeja; alt. 1040, exp. /, incl. /; A 90\%, C 80\%, D 5\%; August 1979; leg. I. Puncer; 27 (22812) Predmeja; alt. 1020, exp. /, incl. /; A 80\%, B 10\%, C 50\%, D 10\%, S 5\%; August 1979; leg. I. Puncer.

\section{Table 10. Omphalodo-Fagetum var. geogr. Saxifraga cuneifolia stellarietosum montanae}

1 (10207) Trnovo, Nemci, Na dolinah; 46,007 $\mathrm{N} 13,769^{\circ}$ E; alt. 880 , exp. S, incl. $20^{\circ}$; A $90 \%$, B $20 \%$, C 50\%, D 10\%, S 20\%; 24.5.2000, leg. B. Surina; 2 (10208) Trnovo, Nemci, doline between peaks Bezgov \& Markov hrib; 46,011 ${ }^{\circ} \mathrm{N} 13,758^{\circ}$ E; alt. 800, exp. /, incl. /; A 80\%, B 80\%, C 60\%, D 40\%, S 40\%; 25.5.2000, leg. B. Surina; 3 (10209) Trnovo, Nemci, Na dolinah; $46,007^{\circ} \mathrm{N} 13,769^{\circ} \mathrm{E}$; alt. 870 , exp. S, incl. $15^{\circ}$; A $70 \%$, B $90 \%$, C 90\%, D 1\%, S 1\%; 24.5.2000, leg. B. Surina; 4 (10210) Trnovo, Nemci, NW from Strgarija; $45,996^{\circ} \mathrm{N}$ $13,787^{\circ}$ E; alt. 900 , exp. /, incl. /; A 70\%, B 30\%, C 100\%, D 50\%, S 50\%; 7.6.2000, leg. B. Surina; 5 (10211) Trnovo, Nemci, Šibrove doline; $46,005^{\circ} \mathrm{N}$ $13,779^{\circ} \mathrm{E}$; alt. 880, exp. /, incl. /; A 60\%, B 30\%, C 100\%, D 10\%; 8.6.2000, leg. B. Surina; 6 (10212) Trnovo, Strgarija; $45,988^{\circ} \mathrm{N} 13,794^{\circ} \mathrm{E}$; alt. 1030 , exp. /, incl. /; A 60\%, B 50\%, C 90\%, D 10\%, S 20\%; 21.6.2000, leg. B. Surina; 7 (10213) Lokve, Mali Češevik; $46,019^{\circ} \mathrm{N} 13,808^{\circ} \mathrm{E}$; alt. 1040, exp. /, incl. /; A 100\%, B 5\%, C 100\%, D 1\%, S 5\%; 9.6.2000, leg. B. Surina; 8 (10214) Predmeja, Pri jelcah; $45,965^{\circ} \mathrm{N} 13,860^{\circ} \mathrm{E}$; alt. 1000 , exp. /, incl. /; A 50\%, B 30\%, C 100\%, D 10\%, S 10\%; 27.6.2000, leg. B. Surina; 9 (10215) Trnovo, Nemci, Na dolinah; $46,007^{\circ} \mathrm{N} 13,760^{\circ} \mathrm{E}$; alt. 820, exp. /, incl. /; A 100\%, B 1\%, C 80\%, D 5\%, S 10\%; 25.5.2000, leg. B. Surina; 10 (10216) Trnovo, Nemci between Kamni breg \& Medvedji vrh; 45,986 ${ }^{\circ} \mathrm{N} 13,761^{\circ} \mathrm{E}$; alt. 800, exp. /, incl. /; A 90\%, B 10\%, C 100\%, D 10\%; 7.6.2000, leg. B. Surina; 11 (22788) Trnovo, 
Nemci; alt. 840, exp. /, incl. /; A 50\%, B 30\%, C 100\%, D 40\%, S 10\%; August 1979, leg. I. Puncer; 12 (22789) Trnovo, Lokve, Turški klanec; 45,994 N 13,812 ${ }^{\circ}$ E; alt. 970, exp. /, incl. /; A 60\%, B 10\%, C 100\%, D 20\%, S 10\%; July 1979, leg. I. Puncer; 13 (22790) Trnovo, Lokve, Turški klanec; $45,995^{\circ} \mathrm{N}$ $13,816^{\circ} \mathrm{E}$; alt. 980 , exp. N, incl. $15^{\circ}$; A $60 \%$, B $10 \%$, C 100\%, D 10\%, S 10\%; July 1979, leg. I. Puncer; 14 (131123) Trnovo, Čepovan, Čepovanska reber;

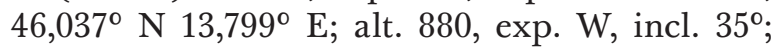
A $90 \%$, B $10 \%$, C 70\%, D 10\%, S 50\%; 4.5.2000, leg. I. Dakskobler; 15 (131124) Trnovo, Čepovan, Čepovanska reber; $46,035^{\circ} \mathrm{N} 13,798^{\circ} \mathrm{E}$; alt. 950 , exp. NW, incl. $30^{\circ}$; A $80 \%$, B $10 \%$, C 70\%, D 10\%, S 40\%; 4.5.2000, leg. I. Dakskobler; 16 (131125) Trnovo, Čepovan, Čepovanska reber; $46,037^{\circ} \mathrm{N}$ $13,801^{\circ} \mathrm{E}$; alt. 970 , exp. W, incl. $35^{\circ}$; A $80 \%$, B $20 \%$, C 70\%, D 20\%, S 50\%; 4.5.2000, leg. I. Dakskobler; 17 (131126) Trnovo, Čepovan, Čepovanska reber; $46,030^{\circ} \mathrm{N} 13,798^{\circ} \mathrm{E}$; alt. 1050 , exp. NW, incl. $30^{\circ}$; A $80 \%$, B $10 \%$, C $70 \%$, D $10 \%$, S $40 \%$; 4.5.2000, leg. I. Dakskobler; 18 (131127) Trnovo, Čepovan, Čepovanska reber; 46,039 $\mathrm{N} 13,803^{\circ}$ E; alt. 970 , exp. NW, incl. $30^{\circ}$; A $80 \%$, B $10 \%$, C 70\%, D 10\%, S 40\%; 4.5.2000, leg. I. Dakskobler; 19 (131129) Trnovo, Čepovan, Čepovanska reber;

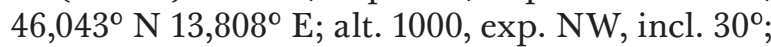
A $90 \%$, B 20\%, C 70\%, D 20\%, S 70\%; 4.5.2000, leg. I. Dakskobler; 20 (131130) Trnovo, Čepovan, Čepovanska reber; $46,037^{\circ} \mathrm{N} 13,803^{\circ} \mathrm{E}$; alt. 1040 , exp. NW, incl. $30^{\circ}$; A $80 \%$, B $10 \%$, C $80 \%$, D $20 \%$, S 70\%; 4.5.2000, leg. I. Dakskobler; 21 (131131) Trnovo, Čepovan, Čepovanska reber; $46,025^{\circ} \mathrm{N}$ $13,795^{\circ} \mathrm{E}$; alt. 1100 , exp. SW, incl. $30^{\circ}$; A $90 \%$, B 5\%, C 70\%, D 10\%, S 40\%; 6.6.2000, leg. I. Dakskobler.

\section{Table 11. Omphalodo-Fagetum var. geogr. Saxifraga cuneifolia calamagrostietosum variae}

1 (131132) Idrija, Kendov vrh; alt. 1030, exp. E, incl. $35^{\circ}$; A $90 \%$, B 10\%, C 50\%, D 10\%, S 30\%; 27.5.1999, leg. I. Dakskobler; 2 (131133) Idrija, Zgornja Idrijca, Bedrova grapa; alt. 970, exp. NE, incl. $35^{\circ}$; A $80 \%$, B $10 \%$, C 50\%, D 10\%, S 20\%; 29.6.1999, leg. I. Dakskobler; 3 (131134) Idrija, Zgornja Idrijca, Bedrova grapa; alt. 1030, exp. $\mathrm{NE}$, incl. $35^{\circ}$; A $80 \%$, B $20 \%$, C $60 \%$, D $10 \%$, S 20\%; 29.6.1999, leg. I. Dakskobler; 4 (217948) Idrija, Govci, Ipavšek, under the Zeleni rob; $45,997^{\circ}$ $\mathrm{N} 13,876^{\circ} \mathrm{E}$; alt. 960 , exp. NE, incl. $40^{\circ}$; A $80 \%$, B 5\%, C 50\%, D 10\%, S 20\%; 9.7.2007, leg. I. Dakskobler; 5 (217955) Idrija, Govci, Ipavšek, under the Zeleni rob; $45,997^{\circ} \mathrm{N} 13,876^{\circ} \mathrm{E}$; alt. 940, exp. NE, incl. $35^{\circ}$; A $80 \%$, B $40 \%$, C $10 \%$, S $20 \%$; 9.7.2007, leg. I. Dakskobler; 6 (217956) Idrija, Govci, Ipavšek, under the Zeleni rob; $45,996^{\circ} \mathrm{N}$ $13,877^{\circ} \mathrm{E}$; alt. 1000 , exp. NE, incl. $30^{\circ}$; A $90 \%$, B 40\%, C 10\%, S 20\%; 9.7.2007, leg. I. Dakskobler; 7 (217957) Idrija, Govci, Ipavšek, under the Zeleni rob; $45,994^{\circ} \mathrm{N} 13,874^{\circ} \mathrm{E}$; alt. 1200 , exp. E, incl. 45여 A 90\%, B 10\%, C 50\%, D 20\%, S 30\%; 9.7.2007, leg. I. Dakskobler; 8 (217992) Idrija, Črna draga,

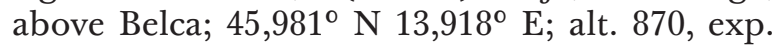
SW, incl. $30^{\circ}$; A 70\%, B 20\%, C 50\%, D 5\%, S 20\%; 8.5.2007, leg. I. Dakskobler; 9 (217993) Idrija, Črna draga, above Belca; $45,982^{\circ} \mathrm{N} 13,918^{\circ} \mathrm{E}$; alt. 900 , exp. SW, incl. $35^{\circ}$; A $80 \%$, B 30\%, C 60\%, D 5\%, S 30\%; 8.5.2007, leg. I. Dakskobler; 10 (217994) Idrija, Črna draga, above Belca; 45,983 N 13,917 E; alt. 940, exp. SW, incl. 40 ; A 80\%, B 30\%, C 60\%, D 5\%, S 40\%; 8.5.2007, leg. I. Dakskobler; 11 (217995); Idrija, Črna draga, above Belca; $45,983^{\circ} \mathrm{N} 13,917^{\circ} \mathrm{E}$; alt. 960, exp. SW, incl. $35^{\circ}$; A $90 \%$, B 20\%, C 60\%, D 5\%, S 20\%; 8.5.2007, leg. I. Dakskobler; 12 (217996) Idrija, Črna draga, under Gnelice; $45,983^{\circ} \mathrm{N} 13,917^{\circ} \mathrm{E}$; alt. 980, exp. SW, incl. $40^{\circ}$; A 80\%, B 20\%, C 60\%, D 5\%, S 20\%; 8.5.2007, leg. I. Dakskobler; 13 (217997) Idrija, Črna draga, under Gnelice; $45,983^{\circ} \mathrm{N}$ $13,917^{\circ} \mathrm{E}$; alt. 980 , exp. SE, incl. $35^{\circ}$; A $90 \%$, B 10\%, C 70\%, D 5\%, S 30\%; 8.5.2007, leg. I. Dakskobler; 14 (218003) Idrija, Črna draga, Belca, above Putrihove klavže; 45,976 ${ }^{\circ} \mathrm{N} 13,927^{\circ} \mathrm{E}$; alt. 680 , exp. S, incl. $35^{\circ}$; A 80\%, B 10\%, C 50\%, D 5\%, S 10\%; 8.5.2007, leg. I. Dakskobler; 15 (230609) Idrija, Gorenja Kanomlja, V Studencu; 46,039 ${ }^{\circ} \mathrm{N}$ $13,912^{\circ} \mathrm{E}$; alt. 830 , exp. NE, incl. $35^{\circ}$; A $80 \%$, B $30 \%$, C 50\%, D 10\%, S 25\%; 13.5.2005, leg. I. Dakskobler; 16 (230612) Idrija, Gorenja Kanomlja, V Studencu; $46,040^{\circ} \mathrm{N} 13,908^{\circ} \mathrm{E}$; alt. 870, exp. NE, incl. $35^{\circ}$; A $70 \%$, B $10 \%$, C 50\%, D 10\%, S 20\%; 14.7.2004, leg. I. Dakskobler; 17 (230613) Idrija, Vojsko, near $\log ; 46,037^{\circ} \mathrm{N} 13,907^{\circ} \mathrm{E}$; alt. 1070, exp. W, incl. $20^{\circ}$; A $90 \%$, B $10 \%$, C $30 \%$, D 10\%, S 30\%; 14.7.2004, leg. I. Dakskobler;

\section{Table 12. Omphalodo-Fagetum var. geogr. Saxifraga cuneifolia seslerietosum autumnalis}

1 (10128) Trnovo, Kamni breg; 45,987 $\mathrm{N}$ $13,771^{\circ} \mathrm{E}$; alt. 865 , exp. E, incl. $15^{\circ}$; A $80 \%$, B $10 \%$, C 80\%, D 5\%, S 10\%; 1.6.2000, leg. B. Surina; 2 (10129) Trnovo, Kopica; 45,976 N 13,784 E; alt. 1010, exp. W, incl. $20^{\circ}$; A $100 \%$, B 30\%, C 10\%, D 5\%, S 5\%; 1.6.2000, leg. B. Surina; 3 (10130) Trnovo, Kopica; $45,971^{\circ} \mathrm{N} 13,783^{\circ} \mathrm{E}$; alt. 1000, exp. SSW, incl. $15^{\circ}$; A 90\%, B 40\%, C 100\%, D 5\%, 
S 5\%; 1.6.2000, leg. B. Surina; 4 (10197) Trnovo, Nemci, between peaks Bezgov \& Markov hrib; $46,011^{\circ} \mathrm{N} 13,758^{\circ} \mathrm{E}$; alt. 830, exp. S, incl. $25^{\circ}$; A $90 \%$, B 10\%, C 50\%, D 30\%, S 60\%; 25.5.2000, leg. B. Surina; 5 (22780) Trnovo; alt. 890, exp. W, incl. $10^{\circ}$; A $100 \%$, B 5\%, C $60 \%$, D 20\%, S 40\%; June 1979, leg. I. Puncer; 6 (22778) Trnovo, Nemci; alt. 900 , exp. S, incl. $20^{\circ}$; A $90 \%$, B $10 \%$, C $70 \%$, D $10 \%$, S 30\%; June 1979, leg. I. Puncer; 7 (22779) Trnovo; alt. 880, exp. SW, incl. $10^{\circ}$; A 90\%, B 5\%, C 40\%, D 30\%, S 50\%; June 1979, leg. I. Puncer; 8 (22777) Trnovo, Nemci; alt. 880, exp. SW, incl. $10^{\circ}$; A $90 \%$, B $10 \%$, C 70\%, D 10\%, S 30\%; June 1979, leg. I. Puncer; 9 (22781) Trnovo; alt. 860, exp. S, incl. $20^{\circ}$; A $80 \%$, B $10 \%$, C $90 \%$, D $10 \%$, S 30\%; June 1979, leg. I. Puncer; 10 (22782) Trnovo; alt. 920, exp. W, incl. $15^{\circ}$; A 90\%, B 20\%, C 90\%, D 5\%, S 20\%; June 1979, leg. I. Puncer; 11 (10131) Predmeja, Krnica, Kucelj; $45,944^{\circ} \mathrm{N} 13,800^{\circ} \mathrm{E}$; alt. 1070 , exp. SE, incl. $20^{\circ}$; A $100 \%$, B $20 \%$, C 90\%, D 10\%, S 20\%; 5.7.2000, leg. B. Surina; 12 (10132) Trnovo, Jančerijski vrh; $45,956^{\circ} \mathrm{N} 13,779^{\circ}$ E; alt. 1000 , exp. WSW, incl. $10^{\circ}$; A 100\%, B 10\%, C 70\%, D 20\%, S 30\%; 2.6.2000, leg. B. Surina; 13 (10133) Trnovo, Korenina; 45,952 ${ }^{\circ} \mathrm{N} 13,778^{\circ}$ E; alt. 985 , exp. NW, incl. $25^{\circ}$; A $100 \%$, B 20\%, C $60 \%$, D 30\%, S 40\%; 2.6.2000, leg. B. Surina; 14 (10134) Trnovo, Kolovrat; 45,959 $\mathrm{N} 13,776^{\circ}$ E; alt. 1010 , exp. W, incl. $20^{\circ}$; A $80 \%$, B $10 \%$, C $70 \%$, D 20\%, S 40\%; 2.6.2000, leg. B. Surina; 15 (10135) Trnovo, Kolovrat; 45,962 ${ }^{\circ} \mathrm{N} 13,786^{\circ} \mathrm{E}$; alt. 955 , exp. S, incl. $15^{\circ}$; A $100 \%$, B $10 \%$, C $70 \%$, D 20\%, S 40\%; 5.7.2000, leg. B. Surina; 16 (10138) Trnovo, Njivica, Krnica; 45,946 N 13,799 ${ }^{\circ}$ E; alt. 1120, exp. SW, incl. 25\%; A 90\%, B 5\%, C 100\%, D 1\%, S 10\%; 5.7.2000, leg. B. Surina.

\section{Table 13. Omphalodo-Fagetum var. geogr. Calamintha grandiflora sambucetosum nigrae}

1 (10188) Idrija, Tisovec, below Nemškarica; $45,954^{\circ} \mathrm{N} 13,946^{\circ} \mathrm{E}$; alt. 850, exp. E, incl. $20^{\circ}$; A $90 \%$, B 30\%, C $80 \%$, D 10\%, S 20\%; 18.7.2000, leg. B. Surina; 2 (10192) Idrija, Orlevc; 45,958 $\mathrm{N} 13,936^{\circ}$ E; alt. 1000 , exp. NE, incl. $20^{\circ}$; A $90 \%$, B 60\%, C 90\%, D 10\%, S 20\%; 20.7.2000, leg. B. Surina; 3 (10193) Idrija, Tisovec, above Belca,

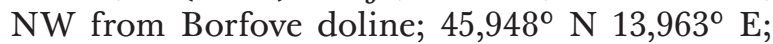
alt. 800 , exp. E, incl. $15^{\circ}$; A $80 \%$, B 50\%, C 70\%, D 10\%, S 20\%; 18.7.2000, leg. B. Surina; 4 (10189) Idrija, Tisovec, Pri Magazinu, towards Borfova dolina; $45,942^{\circ} \mathrm{N} 13,966^{\circ} \mathrm{E}$; alt. 860, exp. W, incl. $25^{\circ}$; A $80 \%$, B 50\%, C 70\%, D 5\%, S 10\%; 18.7.2000, leg. B. Surina; 5 (10190) Idrija, Tisovec; $45,947^{\circ} \mathrm{N}$ $13,958^{\circ} \mathrm{E}$; alt. 840 , exp. NNE, incl. $20^{\circ}$; A $80 \%$, B $60 \%$, C $80 \%$, D 10\%, S 10\%; 19.7.2000, leg. B. Surina; 6 (10191) Idrija, Tisovec; 45,951 ${ }^{\circ} \mathrm{N} 13,957^{\circ}$ E; alt. 850, exp. N, incl. $20^{\circ}$; A 100\%, B 40\%, C 90\%, D 5\%, S 5\%; 19.7.2000, leg. B. Surina.

Table 14. Omphalodo-Fagetum var. geogr. Calamintha grandiflora asaretosum europaei

1 (230602) Idrija, Šebreljski vrh, above Sjavni-

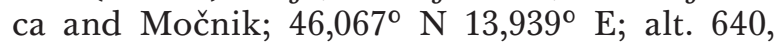
exp. NE, incl. $30^{\circ}$; A $90 \%$, B 10\%, C 40\%, D 5\%, S 10\%; 2.8.2002, leg. I. Dakskobler; 2 (230603) Idrija, Šebreljski vrh, above Sjavnica and Močnik;

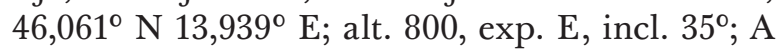
$80 \%$, B 20\%, C 40\%, D 10\%, S 20\%; 2.8.2002, leg. I. Dakskobler; 3 (230604) Idrija, Šebreljski vrh, above Sjavnica and Močnik; 46,062 ${ }^{\circ} \mathrm{N} 13,942^{\circ} \mathrm{E}$; alt. 660 , exp. E, incl. $35^{\circ}$; A $90 \%$, B $10 \%$, C $60 \%$, D 5\%, S 10\%; 2.8.2002, leg. I. Dakskobler; 4 (230605) Idrija, Šebreljski vrh, above Sjavnica and Močnik; $46,064^{\circ} \mathrm{N} 13,941^{\circ} \mathrm{E}$; alt. 650 , exp. NE, incl. $30^{\circ}$; A $90 \%$, B 10\%, C 50\%, D 5\%, S 10\%; 2.8.2002, leg. I. Dakskobler; 5 (230606) Idrija, Šebreljski vrh, above Sjavnica and Močnik; 46, $065^{\circ} \mathrm{N} 13,940^{\circ}$ E; alt. 660, exp. NE, incl. 35\%; A 90\%, B 10\%, C 40\%, D 10\%, S 30\%; 2.8.2002, leg. I. Dakskobler; 6 (230607) Idrija, Gorenja Kanomlja, V Studencu,

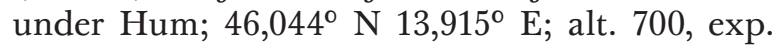
NW, incl. $35^{\circ}$; A $90 \%$, B 10\%, C 60\%, D 20\%, S 30\%; 13.5.2005, leg. I. Dakskobler; 7 (230608) Idrija, Gorenja Kanomlja, V Studencu, under Hum; $46,043^{\circ} \mathrm{N} 13,914^{\circ} \mathrm{E}$; alt. 700, exp. SW, incl. $30^{\circ}$; A $90 \%$, B $10 \%$, C $60 \%$, D 5\%, S 30\%; 13.5.2005, leg. I. Dakskobler; 8 (230611) Idrija, Gorenja Kanomlja, V Studencu, under Hum; 46,047 ${ }^{\circ}$ N 13,918 ${ }^{\circ}$ E; alt. 640 , exp. NW, incl. $30^{\circ}$; A $80 \%$, B 10\%, C 60\%, D 5\%, S 10\%; 14.7.2004, leg. I. Dakskobler.

\subsection{Syntaxonomic units (AND SYNONYMS) WITH COMPLETE NAMES MENTIONED IN THE ARTICLE:}

Amelanchiero ovalis-Ostryetum Poldini 1982, Aremonio-Fagion (Horvat 1938) Borhidi in Török, Podani et Borhidi 1989, Arunco-Fagetum Ž. Košir 1962, Asplenietea trichomanis Br.-Bl. in Meier \& Br.-Bl. 1934, Elyno-Seslerietea Br.-Bl. 1948, EricoPinetea Horvat 1959, Fagetalia sylvaticae Pawl. 1928, Fraxino orni-Pinetum nigrae Martin-Bosse 1967, Hacquetio-Fagetum Ž. Košir (1962) 1979, Hacquetio-Piceetum (Zupančič 1980) 1999, Homogyno sylvestris-Fagetum Marinček \& al. 1993, 
Lamio orvalae-Fagetum (Horvat 1938) Borhidi 1963, Lonicero caeruleae-Piceetum (Zupančič 1980) 1999, Mulgedio-Aconitetea Hadač \& Klika in Klika \& Hadač 1944, Omphalodo-Fagetum (Tregubov 1957 corr. Puncer 1980) Marinček \& al. 1993 var. geogr. Calamintha grandiflora Surina 2002 (=Fagetum croaticum australe abietetosum Horvat 1938; Abieti-Fagetum dinaricum Tregubov 1957; Fago-Abietetum omphalodetosum Trinajstić 2007 nom. ileg.) aceretosum pseudoplatani Puncer 1980, Omphalodo-Fagetum (Tregubov 1957 corr. Puncer 1980) Marinček \& al. 1993 var. geogr. Saxifraga cuneifolia Surina 2002 (=Abieti-Fagetum austroalpinum Puncer 1979 nom. prov.) rhododendretosum hirsuti Dakskobler \& al. 2000, Ostryo-Fagetum M.
Wraber ex Trinajstić 1972, Polysticho lonchitis-Fagetum (Horvat 1938) Marinček in Poldini \& Nardini 1993 var. geogr. Allium victorialis Marinček 1996, Quercetalia pubescentis Klika 1933, QuercoFagetea Br.-Bl. \& Vlieg. 1933, Ranunculo platanifolii-Fagetum Marinček et al. 1993, Rhododendro hirsuti-Fagetum Accetto ex Dakskobler 1998, Rhododendro hirsuti-Pinetum prostratae Zöttl 1951, Ribeso alpini-Piceetum Zupančič \& Accetto 1994, Seslerio autumnalis-Fagetum (Horvat 1938) M. Wraber ex Borhidi 1963, Seslerio autumnalis-Ostryetum Horvat \& Horvatić 1950 corr. Zupančič 1999, Stellario montanae-Fagetum (Zupančič 1969) Marinček \& al. 1993, Thlaspietea rotundifolii Br.-Bl. 1948, Vaccinio-Piceetea Br.-Bl. 1939 em. Zupančič 2000.

Table 4: Synoptic table of the lower syntaxa of the association Omphalodo-Fagetum in the Trnovski gozd plateau (NW Dinaric Alps).

Tabela 4: Sintezna tabela sintaksonov nižjega ranga asociacije Omphalodo-Fagetum v Trnovskem gozdu (severozahodni Dinaridi).

\begin{tabular}{|c|c|c|c|c|c|c|c|c|c|c|c|c|}
\hline $\begin{array}{l}\text { No. of relevés } \\
\text { Lower level syntaxa }\end{array}$ & & $\begin{array}{c}1 \\
\text { rho }\end{array}$ & $\begin{array}{c}2 \\
\text { ade }\end{array}$ & $\begin{array}{c}3 \\
\operatorname{sax}\end{array}$ & $\begin{array}{c}4 \\
\text { cal aru }\end{array}$ & $\begin{array}{c}5 \\
\text { fes I }\end{array}$ & $\begin{array}{c}6 \\
\text { fes II }\end{array}$ & $\begin{array}{c}7 \\
\text { ste }\end{array}$ & $\begin{array}{c}8 \\
\text { cal var }\end{array}$ & $\begin{array}{c}9 \\
\text { ses }\end{array}$ & $\begin{array}{c}10 \\
\text { sam }\end{array}$ & $\begin{array}{c}11 \\
\text { asa }\end{array}$ \\
\hline \multicolumn{13}{|c|}{ Characteristic species of the association Omphalodo-Fagetum } \\
\hline AF Cardamine trifolia & $\mathrm{C} 1$ & $100^{30.6}$ & $89^{27.8}$ & $80^{25.0}$ & $94^{35.6}$ & $88^{32.9}$ & $96^{31.7}$ & $57^{14.8}$ & $35^{7.4}$ & $94^{24.3}$ & $100^{25.0}$ & $75^{19.0}$ \\
\hline AF Aremonia agrimonoides & $\mathrm{C}$ & $6^{1.4}$ & $6^{1.2}$ & $20^{4.4}$ & $71^{17.3}$ & $60^{15.6}$ & $81^{18.9}$ & $48^{10.6}$ & . & $81^{18.1}$ & $100^{18.1}$ & $25^{6.3}$ \\
\hline AF Omphalodes verna & $\mathrm{C}$ & $88^{26.4}$ & $6^{0.6}$ & $40^{18.3}$ & $6^{2.3}$ & . & . & $14^{4.8}$ & $59^{13.6}$ & . & $100^{44.4}$ & $88^{23.8}$ \\
\hline AF Calamintha grandiflora & $\mathrm{C}$ & . & . & $5^{1.1}$ & $6^{1.3}$ & . & . & $5^{1.1}$ & $6^{1.3}$ & . & $100^{20.8}$ & $63^{19.0}$ \\
\hline AF Rhamnus fallax & $\mathrm{B}$ & . & $6^{0.6}$ & . & . & $8^{2.2}$ & $7^{2.1}$ & $10^{2.1}$ & $59^{12.3}$ & $13^{2.8}$ & . & . \\
\hline \multicolumn{13}{|c|}{ Diff. sp. for the geographical variant Saxifraga cuneifolia } \\
\hline VP Saxifraga cuneifolia & $\mathrm{C}$ & $50^{11.1}$ & $6^{1.2}$ & $85^{30.0}$ & $56^{17.0}$ & $32^{9.8}$ & $33^{8.2}$ & $14^{2.6}$ & . & $13^{2.8}$ & . & . \\
\hline AT Paederota lutea & $\mathrm{C}$ & $94^{22.9}$ & $33^{7.4}$ & $40^{18.3}$ & . & $4^{0.9}$ & . & . & $94^{19.7}$ & . & . & . \\
\hline AT Phyteuma scheuchzeri/columnat & & $50^{11.8}$ & $22^{4.3}$ & $20^{5.6}$ & $3^{0.7}$ & . & . & . & $41^{9.8}$ & $19^{4.9}$ & . & . \\
\hline \multirow{3}{*}{ FS Laburnum alpinum } & A & $6^{0.7}$ & . & . & . & . & . & . & $35^{6.7}$ & . & . & $13^{3.2}$ \\
\hline & $\mathrm{B}$ & $6^{0.7}$ & $28^{6.2}$ & $5^{1.1}$ & . & . & . & . & $59^{12.4}$ & . & . & $13^{3.2}$ \\
\hline & $\mathrm{C}$ & . & $11^{3.1}$ & $10^{2.2}$ & 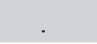 & . & . & . & $94^{21.6}$ & $6^{1.4}$ & $17^{2.8}$ & $13^{3.2}$ \\
\hline \multicolumn{13}{|c|}{ Diff. sp. for the geographical variant Calamintha grandiflora } \\
\hline AF Omphalodes verna & $\mathrm{C}$ & $88^{26.4}$ & $6^{0.6}$ & $40^{18.3}$ & $6^{2.3}$ & . & . & $14^{4.8}$ & $59^{13.6}$ & . & $100^{44.4}$ & $88^{23.8}$ \\
\hline AF Calamintha grandiflora & $\mathrm{C}$ & & . & $5^{1.1}$ & $6^{1.3}$ & . & . & $5^{1.1}$ & $6^{1.3}$ & . & $100^{20.8}$ & $63^{19.0}$ \\
\hline \multicolumn{13}{|c|}{ Differential species for the subassociations } \\
\hline EP Rubus saxatilis & & $100^{28.5}$ & . & $10^{3.9}$ & $6^{1.3}$ & $12^{2.7}$ & . & $5^{1.6}$ & $12^{2.5}$ & . & $67^{12.5}$ & . \\
\hline FS Aruncus dioicus & & $100^{25.7}$ & . & $20^{3.9}$ & . & . & . & $5^{1.1}$ & $29^{6.1}$ & . & . & $38^{9.5}$ \\
\hline MASalix appendiculata & B 1 & $100^{24.3}$ & $6^{0.6}$ & $35^{7.8}$ & $3^{0.7}$ & . & . & . & $12^{1.8}$ & . & $33^{5.6}$ & . \\
\hline EP Rhododendron hirsutum & $\mathrm{B}$ & $94^{58.3}$ & $6^{1.2}$ & $10^{6.7}$ & . & . & . & . & $24^{3.1}$ & . & . & . \\
\hline ES Aster bellidiastrum & $\mathrm{C}$ & $88^{22.2}$ & $33^{7.4}$ & . & . & . & . & . & $12^{1.8}$ & . & . & . \\
\hline ES Carex ferruginea & $\mathrm{C}$ & $50^{9.7}$ & $22^{4.3}$ & $5^{1.1}$ & . & . & . & . & $59^{13.5}$ & . & . & . \\
\hline AT Valeriana saxatilis & $\mathrm{C}$ & $31^{6.3}$ & . & . & . & . & . & . & $6^{0.6}$ & . & . & . \\
\hline AT Primula carniolica & $\mathrm{C}$ & $31^{6.3}$ & . & . & . & . & . & . & . & . & . & . \\
\hline TR Adenostyles glabra & & $100^{24.3}$ & $100^{30.9}$ & $75^{18.9}$ & $94^{28.4}$ & $80^{19.1}$ & $81^{24.3}$ & $33^{7.9}$ & $88^{27.1}$ & $94^{24.3}$ & $17^{2.8}$ & . \\
\hline MAVeratrum album & & $100^{27.1}$ & $100^{24.7}$ & $70^{17.8}$ & $15^{3.3}$ & $32^{8.4}$ & $19^{4.5}$ & $24^{5.3}$ & $24^{6.2}$ & $6^{1.4}$ & . & . \\
\hline MASaxifraga rotundifolia & $\mathrm{C}$ & $6^{1.4}$ & $44^{10.5}$ & . & . & $36^{9.3}$ & $4^{0.8}$ & $10^{2.6}$ & . & . & . & . \\
\hline VP Saxifraga cuneifolia & $\mathrm{C}$ & $50^{11.1}$ & $6^{1.2}$ & $85^{30.0}$ & $56^{17.0}$ & $32^{9.8}$ & $33^{8.2}$ & $14^{2.6}$ & . & $13^{2.8}$ & . & . \\
\hline
\end{tabular}




\begin{tabular}{|c|c|c|c|c|c|c|c|c|c|c|c|c|}
\hline No. of relevés & & 1 & 2 & 3 & 4 & 5 & 6 & 7 & 8 & 9 & 10 & 11 \\
\hline VP Calamagrostis arundinacea & $\mathrm{C}$ & $100^{60.4}$ & $89^{23.5}$ & $95^{63.3}$ & $94^{69.3}$ & $40^{19.1}$ & $67^{29.6}$ & $14^{3.2}$ & $12^{2.5}$ & $88^{27.8}$ & $17^{2.8}$ & $63^{17.5}$ \\
\hline FS Festuca altissima & $\mathrm{C}$ & . & $56^{12.3}$ & $35^{12.8}$ & $68^{22.9}$ & $100^{61.8}$ & $100^{35.0}$ & $90^{27.5}$ & $6^{1.3}$ & $63^{18.1}$ & $100^{25.0}$ & $13^{3.2}$ \\
\hline FS Stellaria montana & $\mathrm{C}$ & . & $22^{4.3}$ & . & $12^{2.3}$ & $68^{21.8}$ & $19^{4.1}$ & $90^{39.2}$ & . & . & $17^{2.8}$ & $13^{4.8}$ \\
\hline FS Impatiens noli-tangere & $\mathrm{C}$ & . & . & . & $3^{0.3}$ & $8^{1.8}$ & . & $81^{32.8}$ & . & . & . & . \\
\hline FS Adoxa moschatellina & $\mathrm{C}$ & $13^{2.8}$ & $22^{5.6}$ & $10^{2.2}$ & $29^{6.5}$ & $36^{7.6}$ & $4^{0.8}$ & $76^{20.1}$ & . & . & . & . \\
\hline FS Arum maculatum & $\mathrm{C}$ & . & . & . & . & $8^{1.8}$ & . & $67^{15.9}$ & . & . & . & $38^{11.1}$ \\
\hline FS Lunaria rediviva & $\mathrm{C}$ & . & . & . & . & . & . & $57^{27.0}$ & $6^{0.6}$ & . & $17^{2.8}$ & . \\
\hline FS Circaea lutetiana & $\mathrm{C}$ & . & $6^{1.9}$ & . & . & $4^{0.9}$ & . & $52^{11.6}$ & . & . & $17^{2.8}$ & . \\
\hline EP Calamagrostis varia & $\mathrm{C}$ & $6^{1.4}$ & $44^{9.9}$ & . & . & . & . & $5^{1.1}$ & $100^{28.9}$ & . & $50^{8.3}$ & . \\
\hline EP Carex alba & $\mathrm{C}$ & . & $17^{3.1}$ & . & $3^{0.7}$ & . & $4^{0.8}$ & . & $71^{20.9}$ & . & $17^{2.8}$ & $13^{3.2}$ \\
\hline FS Polygonatum multiflorum & $\mathrm{C}$ & . & . & . & $6^{1.3}$ & $32^{7.6}$ & $7^{1.6}$ & $38^{8.5}$ & $65^{14.2}$ & $25^{5.6}$ & . & $25^{6.3}$ \\
\hline AF Rhamnus fallax & $\mathrm{B}$ & . & $6^{0.6}$ & . & . & $8^{2.2}$ & $7^{2.1}$ & $10^{2.1}$ & $59^{12.3}$ & $13^{2.8}$ & . & . \\
\hline AF Helleborus niger & $\mathrm{C}$ & $50^{13.9}$ & $22^{5.6}$ & . & . & . & . & . & $53^{15.3}$ & . & . & $13^{3.2}$ \\
\hline EP Buphthalmum salicifolium & $\mathrm{C}$ & . & . & . & . & . & . & . & $41^{8.6}$ & . & . & . \\
\hline QP Sesleria autumnalis & $\mathrm{C}$ & . & . & $10^{5.0}$ & . & $4^{0.9}$ & $7^{2.9}$ & . & . & $100^{77.1}$ & . & . \\
\hline FS Lathyrus vernus/vernus & $\mathrm{C}$ & . & . & $15^{3.9}$ & $26^{7.2}$ & $36^{11.1}$ & $4^{1.2}$ & $38^{8.5}$ & $24^{6.9}$ & $81^{20.1}$ & . & $38^{9.5}$ \\
\hline FS Lathyrus vernus/flaccidus & $\mathrm{C}$ & . & . & $15^{3.3}$ & $24^{6.2}$ & $8^{1.8}$ & . & . & . & $50^{12.5}$ & . & . \\
\hline FS Sambucus nigra & B & . & . & $25^{5.6}$ & $59^{13.4}$ & $52^{12.0}$ & $22^{5.3}$ & $81^{23.8}$ & $12^{2.5}$ & $44^{9.7}$ & $100^{20.8}$ & $50^{14.3}$ \\
\hline \multirow{3}{*}{ FS Tilia platyphyllos } & A & . & . & . & . & . & . & $5^{1.1}$ & . & $6^{1.4}$ & . & . \\
\hline & $\mathrm{B}$ & . & . & . & . & $4^{0.9}$ & . & $14^{3.2}$ & . & $19^{4.2}$ & $50^{8.3}$ & . \\
\hline & $\mathrm{C}$ & . & . & . & . & . & . & $5^{1.1}$ & . & . & $17^{2.8}$ & . \\
\hline FS Asarum europaeum/caucasicum & $\mathrm{C}$ & . & . & . & $3^{0.7}$ & . & . & . & $12^{2.5}$ & $6^{1.4}$ & . & $100^{36.5}$ \\
\hline FS Pulmonaria officinalis & $\mathrm{C}$ & . & . & . & $3^{0.7}$ & . & . & . & $6^{1.3}$ & . & . & $100^{31.7}$ \\
\hline \multirow{3}{*}{ FS Ulmus glabra } & A & . & . & . & . & . & . & $10^{1.1}$ & $6^{1.3}$ & . & $17^{2.8}$ & $88^{34.9}$ \\
\hline & $\mathrm{B}$ & . & . & . & . & . & . & . & $6^{1.3}$ & $6^{1.4}$ & $17^{4.2}$ & $50^{14.3}$ \\
\hline & $\mathrm{C}$ & . & . & . & . & . & . & . & $12^{2.5}$ & . & $17^{4.2}$ & $88^{23.8}$ \\
\hline FS Symphytum tuberosum & $\mathrm{C}$ & $13^{2.8}$ & $28^{6.8}$ & . & $3^{0.7}$ & . & $4^{0.8}$ & $33^{8.5}$ & $18^{3.8}$ & $6^{1.4}$ & . & $88^{28.6}$ \\
\hline FS Petasites albus & $\mathrm{C}$ & . & . & . & . & . & . & . & $6^{1.2}$ & . & $17^{2.8}$ & $75^{30.2}$ \\
\hline QF Hedera helix & $\mathrm{C}$ & . & . & . & . & . & $4^{0.8}$ & . & . & . & . & $75^{20.6}$ \\
\hline \multirow{3}{*}{ QP Fraxinus ornus } & A & . & . & . & . & . & . & . & . & . & . & $38^{6.3}$ \\
\hline & B & . & . & . & . & $8^{1.3}$ & . & $5^{1.1}$ & . & $25^{5.6}$ & . & $25^{6.3}$ \\
\hline & $\mathrm{C}$ & . & . & . & . & . & . & . & $41^{8.0}$ & . & . & $63^{17.5}$ \\
\hline \multirow{2}{*}{ FS Prunus avium } & A & . & . & . & . & . & . & . & . & . & . & $63^{14.3}$ \\
\hline & $\mathrm{C}$ & . & . & . & . & . & . & . & $6^{1.2}$ & . & . & $38^{9.5}$ \\
\hline AF Aremonio-Fagion & & 7 & 10 & 9 & 10 & 8 & 9 & 10 & 13 & 11 & 9 & 14 \\
\hline Cardamine trifolia & $\mathrm{C}$ & $100^{30.6}$ & $89^{27.8}$ & $80^{25.0}$ & $94^{35.6}$ & $88^{32.9}$ & $96^{31.7}$ & $57^{14.8}$ & $35^{7.4}$ & $94^{24.3}$ & $100^{25.0}$ & $75^{19.0}$ \\
\hline Aremonia agrimonoides & $\mathrm{C}$ & $6^{1.4}$ & $6^{1.2}$ & $20^{4.4}$ & $71^{17.3}$ & $60^{15.6}$ & $81^{18.9}$ & $48^{10.6}$ & . & $81^{18.1}$ & $100^{18.1}$ & $25^{6.3}$ \\
\hline Cardamine enneaphyllos & & $100^{31.3}$ & $94^{30.9}$ & $80^{23.3}$ & $85^{30.1}$ & $88^{40.4}$ & $59^{15.6}$ & $90^{31.7}$ & $88^{29.0}$ & $88^{32.6}$ & $83^{15.3}$ & $13^{3.2}$ \\
\hline Cyclamen purpurascens & $\mathrm{C}$ & $25^{4.9}$ & $56^{13.0}$ & $50^{12.2}$ & $50^{15.4}$ & . & $4^{0.8}$ & . & $88^{23.4}$ & $69^{18.1}$ & $83^{19.4}$ & $63^{17.5}$ \\
\hline Euphorbia carniolica & $\mathrm{C}$ & $81^{18.8}$ & $17^{3.7}$ & $15^{3.3}$ & . & $8^{1.8}$ & . & . & $41^{8.7}$ & . & $83^{15.3}$ & $13^{3.2}$ \\
\hline Lamium orvala & $\mathrm{C}$ & . & . & $10^{2.2}$ & $12^{4.6}$ & $48^{16.9}$ & $15^{3.7}$ & $81^{28.0}$ & $24^{6.3}$ & $81^{18.1}$ & $50^{9.7}$ & $100^{42.9}$ \\
\hline Omphalodes verna & $\mathrm{C}$ & $88^{26.4}$ & $6^{0.6}$ & $40^{18.3}$ & $6^{2.3}$ & . & . & $14^{4.8}$ & $59^{13.6}$ & . & $100^{44.4}$ & $88^{23.8}$ \\
\hline Anemone trifolia & $\mathrm{C}$ & . & . & $5^{1.7}$ & $6^{1.3}$ & $12^{3.6}$ & $4^{0.8}$ & $33^{8.5}$ & $6^{1.8}$ & $56^{16.7}$ & . & . \\
\hline Calamintha grandiflora & $\mathrm{C}$ & . & . & $5^{1.1}$ & $6^{1.3}$ & . & . & $5^{1.1}$ & $6^{1.3}$ & . & $100^{20.8}$ & $63^{19.0}$ \\
\hline Rhamnus fallax & $\mathrm{B}$ & . & $6^{0.6}$ & . & . & $8^{2.2}$ & $7^{2.1}$ & $10^{2.1}$ & $59^{12.3}$ & $13^{2.8}$ & . & . \\
\hline Helleborus niger & $\mathrm{C}$ & $50^{13.9}$ & $22^{5.6}$ & . & . & . & . & . & $53^{15.3}$ & . & . & $13^{3.2}$ \\
\hline Hacquetia epipactis & $\mathrm{C}$ & . & $6^{1.9}$ & . & . & . & . & . & $12^{3.7}$ & . & $17^{2.8}$ & $25^{6.3}$ \\
\hline Knautia drymeia & $\mathrm{C}$ & . & . & . & . & . & . & . & $18^{3.7}$ & . & . & $13^{3.2}$ \\
\hline Scopolia carniolica & $\mathrm{C}$ & . & . & . & . & . & . & $10^{3.7}$ & $29^{8.1}$ & . & . & $38^{11.1}$ \\
\hline Helleborus odorus & $\mathrm{C}$ & . & . & . & $3^{0.7}$ & . & . & . & . & $6^{1.4}$ & . & . \\
\hline Polystichum setiferum & $\mathrm{C}$ & . & . & . & . & . & . & $24^{4.8}$ & . & . & . & $25^{6.3}$ \\
\hline Vicia oroboides & $\mathrm{C}$ & . & . & . & . & . & $11^{2.5}$ & . & . & $13^{2.8}$ & . & . \\
\hline
\end{tabular}




\begin{tabular}{|c|c|c|c|c|c|c|c|c|c|c|c|}
\hline No. of relevés & 1 & 2 & 3 & 4 & 5 & 6 & 7 & 8 & 9 & 10 & 11 \\
\hline Daphne laureola & $\mathrm{B}$ & . & $\cdot$ & . & $\cdot$ & . & $\cdot$ & . & 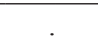 & . & $100^{28.6}$ \\
\hline Geranium nodosum & $\mathrm{C}$ & . & . & . & . & . & $5^{2.6}$ & . & . & . & ${ }^{\circ}$ \\
\hline \multirow{3}{*}{ FS Fagetalia sylvaticae } & & 48 & 41 & 51 & 52 & 45 & 64 & 55 & 44 & 47 & 68 \\
\hline & 32 & 594 & 433 & 561 & 646 & 357 & 862 & 630 & 490 & 550 & 1019 \\
\hline & A $100^{84.0}$ & $100^{95.7}$ & $100^{67.8}$ & $100^{69.6}$ & $100^{78.2}$ & $100^{60.5}$ & $100^{77.8}$ & $100^{87.5}$ & $100^{72.9}$ & $100^{56.9}$ & $100^{79.4}$ \\
\hline \multirow[t]{3}{*}{ Fagus sylvatica } & B $100^{31.9}$ & $100^{34.6}$ & $70^{30.6}$ & $100^{47.1}$ & $72^{28.0}$ & $93^{25.1}$ & $95^{30.7}$ & $100^{37.5}$ & $81^{29.2}$ & $100^{50.0}$ & $88^{31.7}$ \\
\hline & C $69^{15.3}$ & $89^{27.2}$ & $95^{27.2}$ & $100^{36.9}$ & $100^{32.9}$ & $37^{8.6}$ & $76^{21.7}$ & $94^{25.8}$ & $88^{22.9}$ & $100^{19.4}$ & $75^{25.4}$ \\
\hline & A $63^{12.5}$ & $94^{24.7}$ & $20^{5.0}$ & $29^{7.5}$ & $36^{11.6}$ & $15^{3.3}$ & $52^{19.6}$ & $100^{24.6}$ & $6^{1.4}$ & $33^{6.9}$ & $88^{31.7}$ \\
\hline \multirow[t]{2}{*}{ Acer pseudoplatanus } & B $100^{23.6}$ & $89^{25.3}$ & $35^{8.9}$ & $79^{23.5}$ & $80^{24.0}$ & $63^{14.4}$ & $86^{36.5}$ & $24^{5.0}$ & $38^{8.3}$ & $83^{26.4}$ & $25^{6.3}$ \\
\hline & C $\quad 44^{9.7}$ & $83^{28.4}$ & $70^{17.2}$ & $91^{38.6}$ & $96^{35.6}$ & $30^{7.0}$ & $76^{29.6}$ & $94^{23.4}$ & $56^{12.5}$ & $100^{38.9}$ & $88^{31.7}$ \\
\hline Actaea spicata & C $88^{19.4}$ & $28^{5.6}$ & $40^{8.9}$ & $62^{14.1}$ & $60^{14.2}$ & $44^{10.3}$ & $81^{18.5}$ & $47^{11.2}$ & $31^{6.9}$ & $100^{16.7}$ & $100^{30.2}$ \\
\hline Daphne mezereum & B $81^{18.8}$ & $44^{9.9}$ & $90^{22.8}$ & $79^{20.3}$ & $60^{15.1}$ & $56^{12.8}$ & $62^{13.8}$ & $88^{22.8}$ & $94^{22.9}$ & $100^{26.4}$ & $50^{12.7}$ \\
\hline Dryopteris filix-mas & C $81^{17.4}$ & $83^{22.8}$ & $85^{21.1}$ & $100^{27.5}$ & $100^{32.0}$ & $100^{23.0}$ & $100^{41.3}$ & $82^{17.3}$ & $94^{20.8}$ & $100^{18.1}$ & $100^{30.2}$ \\
\hline Epipactis helleborine & $\mathrm{C}$ & $6^{1.2}$ & . & $15^{2.9}$ & $20^{4.0}$ & $22^{4.9}$ & $5^{1.1}$ & $76^{16.0}$ & $31^{6.9}$ & $100^{15.3}$ & $25^{6.3}$ \\
\hline Galeobdolon flavidum & $6^{1.4}$ & $89^{26.5}$ & $45^{10.6}$ & $94^{24.2}$ & $80^{22.2}$ & $85^{21.4}$ & $67^{19.0}$ & $71^{18.5}$ & $94^{20.8}$ & $83^{20.8}$ & $75^{19.0}$ \\
\hline Galium laevigatum & C $13^{2.8}$ & $39^{9.3}$ & $40^{13.3}$ & $18^{5.6}$ & $20^{5.3}$ & $11^{3.7}$ & $19^{4.8}$ & $88^{26.4}$ & $63^{16.7}$ & $50^{8.3}$ & $50^{12.7}$ \\
\hline Mercurialis perennis & C $\quad 63^{17.4}$ & $33^{12.3}$ & $30^{10.6}$ & $26^{14.4}$ & $24^{6.7}$ & $11^{2.5}$ & $52^{15.9}$ & $94^{29.6}$ & $88^{32.6}$ & $100^{38.9}$ & $50^{19.0}$ \\
\hline Mycelis muralis & C $19^{4.2}$ & $78^{18.5}$ & $70^{17.8}$ & $100^{25.8}$ & $84^{20.4}$ & $74^{17.3}$ & $86^{19.0}$ & $65^{14.8}$ & $100^{22.2}$ & $100^{18.1}$ & $50^{12.7}$ \\
\hline Paris quadrifolia & C $69^{15.3}$ & $72^{16.7}$ & $70^{15.6}$ & $76^{16.3}$ & $92^{22.2}$ & $52^{11.5}$ & $100^{24.3}$ & $24^{5.0}$ & $75^{16.7}$ & $100^{16.7}$ & $100^{25.4}$ \\
\hline Polystichum aculeatum & C $81^{18.8}$ & $56^{12.3}$ & $50^{12.2}$ & $38^{8.5}$ & $28^{6.7}$ & $26^{5.8}$ & $52^{12.7}$ & $53^{11.7}$ & $19^{4.2}$ & $83^{15.3}$ & $88^{30.2}$ \\
\hline Prenanthes purpurea & C $100^{28.5}$ & $94^{26.5}$ & $95^{29.4}$ & $94^{30.1}$ & $72^{21.8}$ & $74^{17.3}$ & $38^{10.1}$ & $100^{28.3}$ & $81^{18.1}$ & $100^{25.0}$ & $75^{20.6}$ \\
\hline Epilobium montanum & C $31^{6.9}$ & $56^{13.0}$ & $55^{12.8}$ & $74^{18.6}$ & $44^{12.0}$ & $37^{8.2}$ & $57^{13.2}$ & $6^{1.2}$ & $25^{5.6}$ & $50^{9.7}$ & 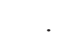 \\
\hline Lonicera alpigena & В $94^{28.5}$ & $17^{3.7}$ & $60^{19.4}$ & $32^{9.2}$ & $32^{11.1}$ & $33^{7.8}$ & $38^{7.9}$ & $65^{16.0}$ & $38^{9.0}$ & $50^{9.7}$ & . \\
\hline Neottia nidus-avis & $\mathrm{C}$ & $78^{16.7}$ & $5^{0.6}$ & $47^{9.8}$ & $48^{9.8}$ & $11^{2.5}$ & $5^{1.1}$ & $59^{12.3}$ & $25^{5.6}$ & $83^{12.5}$ & $13^{3.2}$ \\
\hline Symphytum tuberosum & C $13^{2.8}$ & $28^{6.8}$ & . & $3^{0.7}$ & . & $4^{0.8}$ & $33^{8.5}$ & $18^{3.8}$ & $6^{1.4}$ & . & $88^{28.6}$ \\
\hline Festuca altissima & $\mathrm{C}$ & $56^{12.3}$ & $35^{12.8}$ & $68^{22.9}$ & $100^{61.8}$ & $100^{35.0}$ & $90^{27.5}$ & $6^{1.3}$ & $63^{18.1}$ & $100^{25.0}$ & $13^{3.2}$ \\
\hline Galium odoratum & $\mathrm{C}$ & $61^{17.3}$ & $25^{6.7}$ & $38^{12.4}$ & $88^{33.3}$ & $37^{11.1}$ & $76^{24.3}$ & $6^{1.2}$ & $81^{20.8}$ & $67^{15.3}$ & $50^{15.9}$ \\
\hline Lilium martagon & C $100^{22.2}$ & $44^{9.9}$ & $40^{8.9}$ & $18^{3.9}$ & $8^{2.7}$ & $7^{1.6}$ & . & $41^{9.3}$ & $6^{1.4}$ & . & $13^{3.2}$ \\
\hline Salvia glutinosa & $\mathrm{C}$ & $6^{1.2}$ & . & $3^{0.7}$ & $36^{8.4}$ & $15^{3.3}$ & $76^{17.5}$ & $76^{19.1}$ & $19^{4.2}$ & $67^{12.5}$ & $100^{33.3}$ \\
\hline Sambucus nigra & $\mathrm{C}$ & . & $25^{5.6}$ & $59^{13.4}$ & $52^{12.0}$ & $22^{5.3}$ & $81^{23.8}$ & $12^{2.5}$ & $44^{9.7}$ & $100^{20.8}$ & $50^{14.3}$ \\
\hline Sanicula europaea & $\mathrm{C}$ & $44^{9.9}$ & $5^{1.7}$ & $26^{6.5}$ & $40^{9.3}$ & $26^{5.8}$ & $33^{7.9}$ & $6^{1.2}$ & $13^{2.8}$ & $83^{15.3}$ & $88^{23.8}$ \\
\hline Viola reichenbachiana & C $19^{2.8}$ & . & $15^{3.3}$ & $3^{0.7}$ & $36^{7.1}$ & $22^{4.9}$ & $19^{4.2}$ & . & $31^{6.9}$ & $50^{8.3}$ & $75^{19.0}$ \\
\hline Cardamine bulbifera & $\mathrm{C}$ & $56^{13.6}$ & . & $3^{0.7}$ & $36^{8.9}$ & $7^{1.6}$ & $95^{28.6}$ & $12^{2.5}$ & $13^{2.8}$ & $17^{2.8}$ & $38^{12.7}$ \\
\hline Scrophularia nodosa & $\mathrm{C}$ & $28^{6.2}$ & . & $26^{5.6}$ & $24^{5.3}$ & $11^{2.5}$ & $43^{10.6}$ & $12^{2.5}$ & $31^{6.9}$ & $17^{2.8}$ & $50^{12.7}$ \\
\hline Adoxa moschatellina & C $13^{2.8}$ & $22^{5.6}$ & $10^{2.2}$ & $29^{6.5}$ & $36^{7.6}$ & $4^{0.8}$ & $76^{20.1}$ & . & . & . & . \\
\hline Carex sylvatica & $\mathrm{C}$ & $67^{15.4}$ & . & $12^{2.9}$ & $4^{0.9}$ & $41^{9.1}$ & $24^{5.8}$ & . & $13^{2.8}$ & $83^{13.9}$ & $75^{20.6}$ \\
\hline Lathyrus vernus/vernus & $\mathrm{C}$ & . & $15^{3.9}$ & $26^{7.2}$ & $36^{11.1}$ & $4^{1.2}$ & $38^{8.5}$ & $24^{6.9}$ & $81^{20.1}$ & . & $38^{9.5}$ \\
\hline Phyllitis scolopendrium & $\mathrm{C}$ & $6^{0.6}$ & . & $3^{0.3}$ & $8^{1.8}$ & $7^{2.1}$ & $57^{13.2}$ & $6^{1.2}$ & . & $17^{2.8}$ & $50^{11.1}$ \\
\hline Melica nutans & $6^{1.4}$ & $6^{1.2}$ & $5^{1.7}$ & . & . & . & . & $29^{6.1}$ & $6^{1.4}$ & . & $13^{3.2}$ \\
\hline Phyteuma spicatum/coeruleum & C $\quad 63^{13.9}$ & $67^{15.4}$ & $15^{6.7}$ & $9^{2.0}$ & . & . & . & $76^{18.4}$ & . & . & $38^{9.5}$ \\
\hline Polygonatum multiflorum & $\mathrm{C}$ & . & . & $6^{1.3}$ & $32^{7.6}$ & $7^{1.6}$ & $38^{8.5}$ & $65^{14.2}$ & $25^{5.6}$ & . & $25^{6.3}$ \\
\hline Stellaria montana & $\mathrm{C}$ & $22^{4.3}$ & . & $12^{2.3}$ & $68^{21.8}$ & $19^{4.1}$ & $90^{39.2}$ & . & . & $17^{2.8}$ & $13^{4.8}$ \\
\hline \multirow[t]{2}{*}{ Euphorbia amygdaloides } & $\mathrm{C}$ & . & . & $6^{1.3}$ & $4^{1.3}$ & $4^{0.0}$ & . & $29^{7.4}$ & . & $67^{12.5}$ & $38^{9.5}$ \\
\hline & $6^{0.7}$ & . & . & . & . & . & . & $35^{6.7}$ & . & . & $13^{3.2}$ \\
\hline \multirow[t]{2}{*}{ Laburnum alpinum } & $6^{0.7}$ & $28^{6.2}$ & $5^{1.1}$ & . & . & . & . & $59^{12.4}$ & . & . & $13^{3.2}$ \\
\hline & $\mathrm{C}$ & $11^{3.1}$ & $10^{2.2}$ & . & . & . & . & $94^{21.6}$ & $6^{1.4}$ & $17^{2.8}$ & $13^{3.2}$ \\
\hline Milium effusum & $\mathrm{C}$ & $6^{1.2}$ & $5^{1.1}$ & $3^{0.7}$ & $48^{12.0}$ & $15^{3.3}$ & $43^{12.2}$ & . & . & . & . \\
\hline Poa nemoralis & $6^{1.4}$ & $17^{3.7}$ & . & . & $4^{0.9}$ & . & $5^{1.1}$ & $6^{1.2}$ & . & . & . \\
\hline Ranunculus lanuginosus & $\mathrm{C}$ & . & . & $9^{1.6}$ & . & $4^{0.8}$ & $19^{3.2}$ & . & $19^{4.2}$ & $17^{2.8}$ & $13^{3.2}$ \\
\hline Euphorbia amygdaloides & $\mathrm{C}$ & . & . & $6^{1.3}$ & $4^{1.3}$ & $4^{0.0}$ & . & $29^{7.4}$ & . & $67^{12.5}$ & $38^{9.5}$ \\
\hline Aruncus dioicus & C $100^{25.7}$ & . & $20^{3.9}$ & . & . & . & $5^{1.1}$ & $29^{6.1}$ & . & . & $38^{9.5}$ \\
\hline Cardamine impatiens & $\mathrm{C}$ & . & $5^{1.1}$ & $3^{0.3}$ & $16^{3.6}$ & . & $48^{11.1}$ & . & $6^{0.7}$ & . & . \\
\hline
\end{tabular}




\begin{tabular}{|c|c|c|c|c|c|c|c|c|c|c|c|c|}
\hline No. of relevés & & 1 & 2 & 3 & 4 & 5 & 6 & 7 & 8 & 9 & 10 & 11 \\
\hline Chrysosplenium alternifolium & $\mathrm{C}$ & . & $6^{1.2}$ & . & $3^{0.3}$ & $32^{7.6}$ & $4^{0.8}$ & $57^{15.9}$ & . & . & . & . \\
\hline \multirow{3}{*}{ Fraxinus excelsior } & A & . & $6^{0.6}$ & . & . & . & . & $5^{1.1}$ & $41^{7.4}$ & . & . & $13^{3.2}$ \\
\hline & $\mathrm{B}$ & . & $11^{2.5}$ & . & . & . & . & $10^{2.1}$ & $35^{8.0}$ & . & $50^{8.3}$ & $38^{9.5}$ \\
\hline & $\mathrm{C}$ & . & $11^{1.9}$ & . & $3^{1.0}$ & . & . & . & $53^{15.3}$ & . & $50^{8.3}$ & $75^{25.4}$ \\
\hline Cephalanthera damasonium & $\mathrm{C}$ & . & . & . & . & $4^{0.9}$ & $4^{0.8}$ & . & $6^{1.2}$ & $13^{2.8}$ & . & . \\
\hline Circaea lutetiana & $\mathrm{C}$ & . & $6^{1.9}$ & . & . & $4^{0.9}$ & . & $52^{11.6}$ & . & . & $17^{2.8}$ & . \\
\hline Lathyrus vernus/flaccidus & $\mathrm{C}$ & . & . & $15^{3.3}$ & $24^{6.2}$ & $8^{1.8}$ & . & . & . & $50^{12.5}$ & . & . \\
\hline Myosotis sylvatica & $\mathrm{C}$ & . & $6^{1.9}$ & . & $6^{1.0}$ & $8^{1.8}$ & . & $62^{14.8}$ & . & . & . & . \\
\hline Phyteuma spicatum & $\mathrm{C}$ & $6^{1.4}$ & . & $20^{4.4}$ & . & $4^{0.9}$ & $4^{0.8}$ & . & . & . & . & . \\
\hline Polystichum braunii & $\mathrm{C}$ & $6^{1.4}$ & . & $5^{1.1}$ & $3^{0.7}$ & . & . & $19^{5.3}$ & . & . & . & . \\
\hline \multirow{3}{*}{ Tilia platyphyllos } & A & . & . & . & . & . & . & $5^{1.1}$ & . & $6^{1.4}$ & . & . \\
\hline & $\mathrm{B}$ & . & . & . & . & $4^{0.9}$ & . & $14^{3.2}$ & . & $19^{4.2}$ & $50^{8.3}$ & . \\
\hline & $\mathrm{C}$ & . & . & . & . & . & . & $5^{1.1}$ & . & . & $17^{2.8}$ & . \\
\hline \multirow{3}{*}{ Ulmus glabra } & A & . & . & . & . & . & . & $10^{1.1}$ & $6^{1.3}$ & . & $17^{2.8}$ & $88^{34.9}$ \\
\hline & $\mathrm{B}$ & . & . & . & . & . & . & . & $6^{1.3}$ & $6^{1.4}$ & $17^{4.2}$ & $50^{14.3}$ \\
\hline & $\mathrm{C}$ & . & . & . & . & . & . & . & $12^{2.5}$ & . & $17^{4.2}$ & $88^{23.8}$ \\
\hline Arum maculatum & $\mathrm{C}$ & . & . & . & . & $8^{1.8}$ & . & $67^{15.9}$ & . & . & . & $38^{11.1}$ \\
\hline Campanula trachelium & $\mathrm{C}$ & . & $6^{1.2}$ & . & . & . & . & $14^{3.2}$ & . & . & . & $63^{15.9}$ \\
\hline Cardamine pentaphyllos & $\mathrm{C}$ & . & . & $5^{1.1}$ & . & . & . & $38^{19.6}$ & . & . & $50^{13.9}$ & . \\
\hline Impatiens noli-tangere & $\mathrm{C}$ & . & . & . & $3^{0.3}$ & $8^{1.8}$ & . & $81^{32.8}$ & . & . & . & . \\
\hline Lunaria rediviva & $\mathrm{C}$ & . & . & . & . & . & . & $57^{27.0}$ & $6^{0.6}$ & . & $17^{2.8}$ & . \\
\hline Veronica montana & $\mathrm{C}$ & . & . & . & $3^{0.7}$ & $8^{2.2}$ & $4^{0.8}$ & . & . & . & . & . \\
\hline \multirow{3}{*}{ Acer platanoides } & A & . & . & . & . & . & . & $5^{1.1}$ & . & . & . & . \\
\hline & $\mathrm{B}$ & . & . & . & . & . & . & $14^{3.2}$ & . & . & . & $13^{3.2}$ \\
\hline & $\mathrm{C}$ & . & . & . & . & . & . & $5^{1.1}$ & . & . & . & $25^{7.9}$ \\
\hline Allium ursinum & $\mathrm{C}$ & . & . & . & . & . & . & $5^{1.1}$ & . & . & . & $25^{6.3}$ \\
\hline Circaea alpina & $\mathrm{C}$ & . & $22^{4.9}$ & . & . & . & $4^{0.8}$ & . & . & . & . & . \\
\hline Dryopteris affinis & $\mathrm{C}$ & . & . & . & . & . & . & . & $6^{1.2}$ & . & . & $25^{6.3}$ \\
\hline \multirow{3}{*}{ Acer campestre } & A & . & . & . & . & . & . & . & . & . & . & $38^{9.5}$ \\
\hline & $\mathrm{B}$ & . & . & . & . & . & . & . & . & . & . & $13^{3.2}$ \\
\hline & $\mathrm{C}$ & . & . & . & . & . & . & . & . & . & . & $13^{3.2}$ \\
\hline \multirow{2}{*}{ QP Quercetalia pubescentis } & & 4 & 4 & 6 & 5 & 5 & 6 & 7 & 8 & 8 & 3 & 8 \\
\hline & & 38 & 0 & 26 & 23 & 8 & 6 & 7 & 36 & 104 & 17 & 67 \\
\hline \multirow{3}{*}{ Sorbus aria } & A & $31^{6.3}$ & $6^{0.6}$ & $20^{5.0}$ & $9^{2.0}$ & . & . & $5^{0.5}$ & $29^{5.5}$ & $6^{1.4}$ & $17^{2.8}$ & $25^{6.3}$ \\
\hline & $\mathrm{B}$ & $88^{19.4}$ & $39^{8.6}$ & $55^{12.8}$ & $50^{11.8}$ & $8^{1.8}$ & $30^{6.6}$ & . & $24^{6.8}$ & $25^{5.6}$ & $50^{8.3}$ & $13^{3.2}$ \\
\hline & $\mathrm{C}$ & $13^{2.8}$ & $11^{2.5}$ & $60^{13.9}$ & $32^{7.5}$ & $12^{2.7}$ & $4^{0.8}$ & . & $47^{9.8}$ & $25^{5.6}$ & $33^{5.6}$ & . \\
\hline Arabis turrita & $\mathrm{C}$ & . & . & . & $3^{1.0}$ & $4^{0.9}$ & $4^{0.8}$ & $10^{2.1}$ & . & $6^{1.4}$ & . & . \\
\hline Convallaria majalis & $\mathrm{C}$ & $44^{9.0}$ & . & $5^{1.1}$ & . & . & . & . & . & $25^{6.3}$ & . & . \\
\hline \multirow{3}{*}{ Fraxinus ornus } & A & . & . & . & . & . & . & . & . & . & . & $38^{6.3}$ \\
\hline & $\mathrm{B}$ & . & . & . & . & $8^{1.3}$ & . & $5^{1.1}$ & . & $25^{5.6}$ & . & $25^{6.3}$ \\
\hline & $\mathrm{C}$ & . & . & . & . & . & . & . & $41^{8.0}$ & . & . & $63^{17.5}$ \\
\hline \multirow{2}{*}{ Ostrya carpinifolia } & A & . & . & . & . & . & $4^{0.8}$ & $5^{0.5}$ & . & . & . & $75^{22.2}$ \\
\hline & $\mathrm{B}$ & . & . & . & . & . & . & . & $24^{3.8}$ & . & . & . \\
\hline Sesleria autumnalis & $\mathrm{C}$ & . & . & $10^{5.0}$ & . & $4^{0.9}$ & $7^{2.9}$ & . & . & $100^{77.1}$ & . & . \\
\hline Melittis melissophyllum & $\mathrm{C}$ & . & . & $5^{1.1}$ & . & . & . & . & $35^{7.4}$ & . & . & $13^{3.2}$ \\
\hline Piptatherum virescens & $\mathrm{C}$ & . & $6^{1.2}$ & . & . & . & $4^{0.8}$ & $10^{2.1}$ & . & . & . & . \\
\hline Digitalis grandiflora & $\mathrm{C}$ & . & . & . & . & . & . & $5^{1.1}$ & $6^{0.6}$ & . & . & . \\
\hline Tamus communis & $\mathrm{C}$ & . & . & . & . & . & . & . & . & $6^{1.4}$ & . & $13^{1.6}$ \\
\hline QR Quercetalia roboris-petraeae & & . & . & . & . & . & $\begin{array}{l}1 \\
1\end{array}$ & . & $\cdot$ & $\begin{array}{l}1 \\
1\end{array}$ & . & $\begin{array}{c}4 \\
16\end{array}$ \\
\hline Betula pendula & A & . & . & . & . & . & . & . & . & . & . & $13^{1.6}$ \\
\hline Frangula alnus & $\mathrm{B}$ & . & . & . & . & . & . & . & . & $6^{1.4}$ & . & . \\
\hline
\end{tabular}




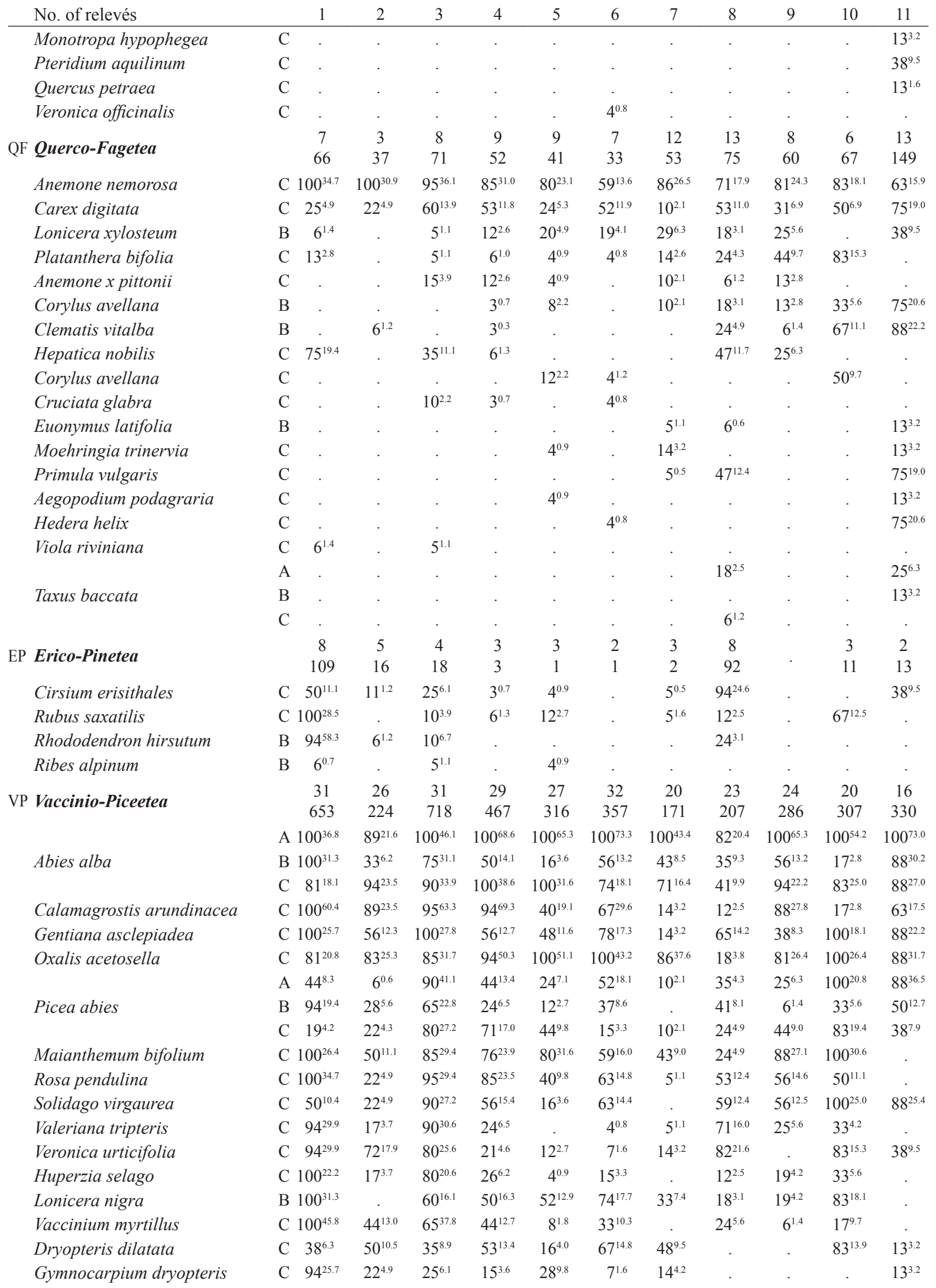




\begin{tabular}{|c|c|c|c|c|c|c|c|c|c|c|c|}
\hline No. of relevés & 1 & 2 & 3 & 4 & 5 & 6 & 7 & 8 & 9 & 10 & 11 \\
\hline Hieracium murorum & C $31^{6.9}$ & $11^{2.5}$ & $35^{8.9}$ & $9^{2.3}$ & $16^{3.6}$ & $4^{0.8}$ & . & $53^{11.0}$ & $6^{1.4}$ & . & . \\
\hline Homogyne sylvestris & C $\quad 94^{25.7}$ & $6^{1.9}$ & $75^{26.7}$ & $21^{5.9}$ & $8^{1.8}$ & $15^{3.3}$ & . & $53^{14.7}$ & . & $33^{6.9}$ & . \\
\hline Saxifraga cuneifolia & C $50^{11.1}$ & $6^{1.2}$ & $85^{30.0}$ & $56^{17.0}$ & $32^{9.8}$ & $33^{8.2}$ & $14^{2.6}$ & . & $13^{2.8}$ & . & . \\
\hline Clematis alpina & C $100^{29.9}$ & . & $90^{48.9}$ & $12^{4.9}$ & $4^{0.9}$ & $4^{0.8}$ & . & $47^{11.7}$ & $19^{4.9}$ & . & . \\
\hline Dryopteris expansa & C $63^{13.9}$ & $22^{5.6}$ & $10^{2.2}$ & $15^{3.6}$ & $16^{3.6}$ & . & $38^{9.0}$ & . & $13^{2.8}$ & . & . \\
\hline Luzula luzuloides & $\mathrm{C} \quad 6^{1.4}$ & . & $55^{18.3}$ & $74^{24.5}$ & $68^{18.7}$ & $63^{15.6}$ & $38^{7.9}$ & . & $88^{20.8}$ & . & . \\
\hline Phegopteris connectilis & C $88^{24.3}$ & . & $35^{8.9}$ & $9^{2.3}$ & . & $11^{2.5}$ & $24^{5.8}$ & . & . & . & . \\
\hline Polystichum lonchitis & C $100^{27.1}$ & $6^{0.6}$ & $30^{7.2}$ & $3^{0.7}$ & $4^{1.3}$ & . & $10^{2.1}$ & . & . & . & . \\
\hline Luzula sylvatica/sylvatica & C $13^{2.8}$ & $39^{9.3}$ & $30^{8.3}$ & . & . & $7^{1.6}$ & $5^{1.1}$ & . & . & . & . \\
\hline Aposeris foetida & $\mathrm{C}$ & $50^{11.7}$ & $10^{2.2}$ & . & . & . & . & $41^{11.7}$ & $6^{1.4}$ & . & . \\
\hline Orthilia secunda & $\mathrm{C}$ & . & . & $3^{1.0}$ & $4^{0.9}$ & $26^{6.2}$ & . & . & $6^{1.4}$ & . & . \\
\hline Blechnum spicant & $\mathrm{C}$ & . & . & . & . & $4^{0.8}$ & . & . & . & $17^{2.8}$ & $25^{6.3}$ \\
\hline Lycopodium annotinum & C $63^{12.5}$ & . & $10^{2.8}$ & . & . & . & . & . & . & . & . \\
\hline Monotropa hypopitys & $\mathrm{C}$ & . & . & . & $4^{0.9}$ & $4^{0.8}$ & . & . & . & $17^{2.8}$ & . \\
\hline Rubus hirtus & $\mathrm{B}$ & . & . & . & . & $19^{4.1}$ & . & $12^{2.5}$ & . & . & $75^{20.6}$ \\
\hline Vaccinium vitis-idaea & C $31^{6.3}$ & . & $15^{4.4}$ & . & . & . & . & . & . & . & . \\
\hline Calamagrostis villosa & $\mathrm{C}$ & $6^{3.1}$ & . & . & . & . & . & . & . & . & . \\
\hline Corallorhiza trifida & $6^{0.7}$ & $6^{1.2}$ & . & . & . & . & . & . & . & . & . \\
\hline Galium rotundifolium & $\mathrm{C}$ & . & . & $3^{0.7}$ & . & $4^{0.8}$ & . & . & . & . & . \\
\hline Luzula pilosa & $\mathrm{C}$ & . & . & $3^{0.7}$ & . & . & . & . & $6^{1.4}$ & . & . \\
\hline Thelypteris limbosperma & $\mathrm{C}$ & . & . & . & . & $7^{1.6}$ & . & . & . & . & $13^{3.2}$ \\
\hline MA Mulgedio-Aconitetea & 16 & 14 & 12 & 11 & 9 & 9 & 15 & 13 & 7 & 5 & 7 \\
\hline MAMUlgedio-Aconitetea & 154 & 144 & 36 & 11 & 23 & 3 & 149 & 71 & 4 & 8 & 30 \\
\hline Athyrium filix-femina & C $100^{30.6}$ & $94^{29.0}$ & $60^{15.6}$ & $94^{28.1}$ & $84^{24.9}$ & $81^{19.3}$ & $100^{40.7}$ & $29^{6.2}$ & $38^{8.3}$ & $100^{22.2}$ & $88^{38.1}$ \\
\hline Polygonatum verticillatum & C $100^{30.6}$ & $100^{25.3}$ & $95^{30.6}$ & $85^{21.9}$ & $40^{9.3}$ & $48^{10.7}$ & $57^{12.7}$ & $65^{16.0}$ & $50^{13.2}$ & $100^{18.1}$ & $13^{3.2}$ \\
\hline Senecio ovatus & $\mathrm{C} \quad 6^{0.7}$ & $83^{21.0}$ & $60^{13.9}$ & $100^{26.5}$ & $96^{26.7}$ & $63^{16.0}$ & $90^{28.6}$ & $82^{21.6}$ & $94^{23.6}$ & $83^{29.2}$ & $100^{33.3}$ \\
\hline Geranium robertianum & $\mathrm{C}$ & $11^{1.9}$ & $15^{3.3}$ & $79^{19.3}$ & $72^{19.1}$ & $52^{13.2}$ & $62^{16.4}$ & $12^{2.5}$ & $69^{15.3}$ & . & $13^{3.2}$ \\
\hline Heracleum sphondylium & $\mathrm{C}$ & $44^{9.3}$ & . & $3^{0.7}$ & . & $4^{0.8}$ & $19^{4.2}$ & $24^{4.9}$ & . & $17^{2.8}$ & $13^{3.2}$ \\
\hline Urtica dioica & $\mathrm{C}$ & $11^{1.9}$ & $10^{2.2}$ & $26^{5.9}$ & $44^{10.7}$ & $4^{0.8}$ & $90^{30.7}$ & . & $13^{2.8}$ & . & . \\
\hline Ranunculus platanifolius & C $94^{24.3}$ & $72^{13.6}$ & $70^{18.3}$ & $12^{2.6}$ & $8^{2.2}$ & . & . & $6^{0.6}$ & . & . & . \\
\hline Salix appendiculata & B $100^{24.3}$ & $6^{0.6}$ & $35^{7.8}$ & $3^{0.7}$ & . & . & . & $12^{1.8}$ & . & $33^{5.6}$ & . \\
\hline Doronicum austriacum & C $13^{1.4}$ & . & $15^{3.3}$ & $3^{0.3}$ & $4^{0.9}$ & $4^{0.8}$ & . & . & . & . & $38^{11.1}$ \\
\hline Thalictrum aquilegiifolium & C $\quad 50^{11.1}$ & . & $5^{1.1}$ & . & . & . & $5^{1.1}$ & $6^{1.2}$ & $6^{1.4}$ & . & . \\
\hline Saxifraga rotundifolia & $6^{1.4}$ & $44^{10.5}$ & . & . & $36^{9.3}$ & $4^{0.8}$ & $10^{2.6}$ & . & . & . & . \\
\hline Aconitum degenii/paniculatum & $\mathrm{C}$ & $6^{0.6}$ & . & . & . & . & $5^{1.1}$ & $18^{3.7}$ & . & . & . \\
\hline Aconitum lycoctonum & $\mathrm{C}$ & $6^{1.2}$ & . & . & . & . & $14^{3.2}$ & $24^{6.7}$ & . & . & . \\
\hline Angelica sylvestris & C $19^{2.1}$ & . & . & . & . & . & . & $6^{1.2}$ & . & . & $50^{12.7}$ \\
\hline Centaurea montana & C $19^{4.2}$ & . & . & . & . & . & . & $24^{4.9}$ & . & . & . \\
\hline Phyteuma ovatum & $\mathrm{C}$ & . & $10^{2.2}$ & $3^{0.7}$ & . & . & . & . & . & . & . \\
\hline Viola biflora & C $\quad 50^{10.4}$ & . & $5^{1.1}$ & . & . & . & . & . & . & . & . \\
\hline FS Flvno-Seslorioton & 3 & 3 & 1 & & & & & 5 & & & 1 \\
\hline LS Еtyno-sestertetea & 34 & 14 & 1 & . & . & $\cdot$ & . & 20 & $\cdot$ & . & 3 \\
\hline Carex ferruginea & C $\quad 50^{9.7}$ & $22^{4.3}$ & $5^{1.1}$ & . & . & . & . & $59^{13.5}$ & . & . & . \\
\hline Aster bellidiastrum & C $88^{22.2}$ & $33^{7.4}$ & . & . & . & . & . & $12^{1.8}$ & . & . & . \\
\hline Sesleria caerulea/calcaria & $\mathrm{C}$ & $11^{1.9}$ & . & . & . & . & . & $12^{2.5}$ & . & . & . \\
\hline AT Asnlenietea trichomanis & 13 & 9 & 10 & 9 & 9 & 7 & 7 & 10 & 7 & 5 & 4 \\
\hline Al Asplentetea trichomanis & 13 & 43 & 123 & 84 & 50 & 39 & 39 & 67 & 63 & 47 & 32 \\
\hline Asplenium trichomanes & C $63^{12.5}$ & $33^{7.4}$ & $70^{16.7}$ & $91^{21.9}$ & $64^{14.2}$ & $59^{15.2}$ & $62^{13.8}$ & $29^{6.1}$ & $63^{13.9}$ & $100^{16.7}$ & $75^{19.0}$ \\
\hline Asplenium viride & C $100^{26.4}$ & $28^{6.2}$ & $100^{28.3}$ & $62^{16.0}$ & $24^{6.7}$ & $33^{7.8}$ & $5^{1.1}$ & $59^{12.3}$ & $44^{9.7}$ & $100^{16.7}$ & $13^{3.2}$ \\
\hline Moehringia muscosa & C $25^{4.9}$ & $11^{2.5}$ & $55^{12.2}$ & $53^{13.4}$ & $24^{4.9}$ & $30^{7.0}$ & $10^{2.1}$ & $18^{3.8}$ & $44^{9.7}$ & $17^{2.8}$ & . \\
\hline Polypodium vulgare & $6^{0.7}$ & . & $35^{7.8}$ & $41^{9.5}$ & $56^{12.9}$ & $22^{5.3}$ & $33^{7.4}$ & $12^{2.5}$ & $44^{9.7}$ & $17^{2.8}$ & $25^{6.3}$ \\
\hline Cystopteris fragilis & C $\quad 75^{17.4}$ & $50^{10.5}$ & $55^{14.4}$ & $50^{11.1}$ & $32^{7.1}$ & $4^{0.8}$ & $52^{11.6}$ & $18^{3.7}$ & . & $50^{8.3}$ & . \\
\hline
\end{tabular}




\begin{tabular}{|c|c|c|c|c|c|c|c|c|c|c|c|c|}
\hline No. of relevés & & 1 & 2 & 3 & 4 & 5 & 6 & 7 & 8 & 9 & 10 & 11 \\
\hline Asplenium ruta-muraria & $\mathrm{C}$ & $75^{16.0}$ & 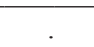 & $50^{15.0}$ & $41^{10.1}$ & $4^{0.9}$ & $7^{1.6}$ & . & $35^{7.4}$ & $50^{11.8}$ & . & $13^{3.2}$ \\
\hline Phyteuma scheuchzeri/columnae & $\mathrm{C}$ & $50^{11.8}$ & $22^{4.3}$ & $20^{5.6}$ & $3^{0.7}$ & . & . & . & $41^{9.8}$ & $19^{4.9}$ & . & . \\
\hline Paederota lutea & $\mathrm{C}$ & $94^{22.9}$ & $33^{7.4}$ & $40^{18.3}$ & . & $4^{0.9}$ & . & . & $94^{19.7}$ & . & . & . \\
\hline Cystopteris montana & $\mathrm{C}$ & $6^{1.4}$ & . & $15^{3.3}$ & $3^{0.7}$ & $4^{0.4}$ & . & . & . &. & . & . \\
\hline Carex brachystachys & $\mathrm{C}$ & $19^{3.5}$ & $11^{1.9}$ & $5^{1.1}$ & . & . & . & 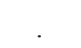 & $6^{1.2}$ & . & . & . \\
\hline Cymbalaria muralis & C & . & . & & & $8^{1.8}$ & $4^{0.8}$ & $5^{1.1}$ & . & $13^{3.5}$ & & . \\
\hline Cystopteris regia & C & $13^{2.1}$ & $6^{0.6}$ & . & . & . & . & & . & . & . & . \\
\hline Sedum hispanicum & C & . & $11^{2.5}$ & . & $3^{0.7}$ & . & . & $14^{2.1}$ & . & . & . & . \\
\hline Valeriana saxatilis & $\mathrm{C}$ & $31^{6.3}$ & . & . & . & . & . & . & $6^{0.6}$ & . & . & . \\
\hline & & 3 & 1 & 2 & 3 & 2 & 1 & 1 & 3 & 2 & 1 & 1 \\
\hline In & & 40 & 31 & 36 & 28 & 19 & 24 & 8 & 36 & 24 & 3 & 2 \\
\hline Adenostyles glabra & & $100^{24.3}$ & $100^{30.9}$ & $75^{18.9}$ & $94^{28.4}$ & $80^{19.1}$ & $81^{24.3}$ & $33^{7.9}$ & $88^{27.1}$ & $94^{24.3}$ & $17^{2.8}$ & . \\
\hline Gymnocarpium robertianum & C & $75^{14.6}$ & . & $30^{7.2}$ & . & ${ }^{\circ}$ & . & . & $35^{7.4}$ & . & . & $13^{1.6}$ \\
\hline Astrantia carniolica & C & . & . & . & . & . & . & . & $6^{1.8}$ & . & . & . \\
\hline Hypericum perforatum & $\mathrm{C}$ & . & . & . & $3^{0.7}$ & $4^{0.9}$ & . & . & . & . & . & . \\
\hline Anthriscus fumarioides & $\mathrm{C}$ & & . & . & . & . & . & . & . & $25^{6.9}$ & . & . \\
\hline Arabis alpina & $\mathrm{C}$ & . & . & . & $3^{0.7}$ & . & . & . & . & . & . & . \\
\hline Dryopteris villarii & $\mathrm{C}$ & $6^{1.4}$ & . & . & . & . & . & . & . & . & . & . \\
\hline Other species & & $\begin{array}{c}9 \\
71\end{array}$ & $\begin{array}{c}7 \\
60\end{array}$ & $\begin{array}{l}10 \\
77\end{array}$ & $\begin{array}{l}12 \\
94\end{array}$ & $\begin{array}{l}11 \\
83\end{array}$ & $\begin{array}{l}12 \\
64\end{array}$ & $\begin{array}{l}16 \\
75\end{array}$ & $\begin{array}{l}13 \\
41\end{array}$ & $\begin{array}{c}6 \\
50\end{array}$ & $\begin{array}{c}10 \\
172\end{array}$ & $\begin{array}{c}9 \\
63\end{array}$ \\
\hline Rubus idaeus & B & $81^{21.5}$ & $89^{24.7}$ & $80^{20.0}$ & $94^{25.2}$ & $96^{28.0}$ & $74^{17.3}$ & $67^{21.2}$ & $35^{7.4}$ & $69^{18.1}$ & $100^{18.1}$ & $25^{6.3}$ \\
\hline & A & $44^{9.0}$ & . & $20^{5.6}$ & $6^{1.3}$ & & $11^{2.9}$ & $5^{1.1}$ & $6^{1.3}$ & & r. & . \\
\hline Sorbus aucuparia & B & $88^{21.5}$ & $61^{13.6}$ & $40^{10.6}$ & $62^{15.4}$ & $48^{12.4}$ & $74^{17.7}$ & $48^{10.6}$ & $6^{1.3}$ & $25^{5.6}$ & $33^{6.9}$ & . \\
\hline & $\mathrm{C}$ & $31^{6.9}$ & $61^{14.8}$ & $85^{20.0}$ & $82^{20.6}$ & $68^{18.7}$ & $19^{4.1}$ & $38^{7.9}$ & $35^{7.4}$ & $31^{6.9}$ & $100^{16.7}$ & . \\
\hline Fragar & C & . & $11^{2.5}$ & $30^{6.7}$ & $32^{7.2}$ & $16^{3.6}$ & $26^{5.8}$ & $29^{6.3}$ & . & $25^{5.6}$ & $33^{5.6}$ & $13^{3.2}$ \\
\hline Is racemosa & B & $13^{1.4}$ & $6^{0.6}$ & $10^{2.2}$ & $9^{2.3}$ & $16^{4.0}$ & . & $10^{2.1}$ & $6^{0.6}$ & $13^{2.8}$ & . & . \\
\hline Solanum dulcamara & C & & . & $20^{4.4}$ & $47^{10.8}$ & $16^{3.6}$ & $41^{11.1}$ & $48^{10.6}$ & $6^{1.2}$ & $44^{11.1}$ & $83^{13.9}$ & . \\
\hline Polystichum x luerssenii & $\mathrm{C}$ & $19^{3.5}$ & $6^{1.2}$ & . & $6^{1.3}$ & $8^{1.8}$ & $4^{0.8}$ & $24^{5.3}$ & . & . & . & $38^{9.5}$ \\
\hline Galeopsis speciosa & $\mathrm{C}$ & . & $17^{3.1}$ & . & $9^{2.0}$ & $24^{5.3}$ & $4^{1.2}$ & $10^{2.1}$ & . & . & $17^{2.8}$ & . \\
\hline Atropa bella-donna & $\mathrm{C}$ & . & . & & $3^{0.3}$ & $4^{0.9}$ & & $10^{1.6}$ & $12^{1.8}$ & . & $17^{2.8}$ & \\
\hline Dactylorhiza maculata & $\mathrm{C}$ & $6^{1.4}$ & . & $5^{0.6}$ & $32^{7.2}$ & $20^{3.6}$ & $4^{0.8}$ & . & & . & . & . \\
\hline Eupatorium cannabinum & $\mathrm{C}$ & . & . & . & $3^{0.3}$ & . & . & $5^{1.1}$ & $47^{11.0}$ & . & $67^{11.1}$ & . \\
\hline Rubus fruticosus agg. & C & $6^{1.4}$ & . & . & . & . & . & . & . & . & $33^{6.9}$ & . \\
\hline Ajuga reptans & C & . & . & . & . & . & $4^{0.8}$ & . & . & . & . & $38^{9.5}$ \\
\hline Hypericum hirsutum & C & . & . & . & . & . & . & . & . & . & $17^{2.8}$ & $38^{9.5}$ \\
\hline Polystichum x bicknellii & $\mathrm{C}$ & . & . & . & . & $\cdot$ & . & " & $6^{1.2}$ & . & . & $25^{12.7}$ \\
\hline Deschampsia cespitosa & $\mathrm{C}$ & . & . & . & & $4^{0.9}$ & . & $5^{1.1}$ & . & . & & . \\
\hline Polystichum x illyricum & $\mathrm{C}$ & . & . & $5^{1.1}$ & . & . & . & $5^{1.1}$ & . & 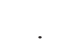 & . & . \\
\hline Viscum album/abietis & A & . & . & . & . & . & $4^{0.8}$ & . & . & . & . & $25^{6.3}$ \\
\hline Lichens and mosses & & $\begin{array}{c}53 \\
476\end{array}$ & $\begin{array}{c}31 \\
219\end{array}$ & $\begin{array}{c}48 \\
209\end{array}$ & $\begin{array}{c}17 \\
132\end{array}$ & $\begin{array}{c}16 \\
123\end{array}$ & $\begin{array}{c}33 \\
206\end{array}$ & $\begin{array}{c}45 \\
190\end{array}$ & $\begin{array}{c}17 \\
124\end{array}$ & $\begin{array}{c}22 \\
156\end{array}$ & $\begin{array}{c}15 \\
122\end{array}$ & $\begin{array}{c}21 \\
183\end{array}$ \\
\hline Ctenidium molluscum & & $100^{45.8}$ & $100^{38.3}$ & $75^{34.4}$ & $76^{34.0}$ & $80^{34.7}$ & $96^{399}$ & $62^{19.6}$ & $82^{24.7}$ & $88^{37.5}$ & $83^{26.4}$ & $100^{31.7}$ \\
\hline Neckera crispa & D & $63^{15.3}$ & $17^{3.7}$ & $50^{18.9}$ & $47^{21.2}$ & $72^{28.4}$ & $70^{22.2}$ & $57^{20.1}$ & $65^{16.1}$ & $81^{27.8}$ & $50^{9.7}$ & $63^{20.6}$ \\
\hline Polytrichum formo & D & $88^{20.8}$ & $44^{9.9}$ & $30^{10.0}$ & $9^{3.3}$ & . & $70^{16.0}$ & $10^{2.1}$ & $47^{10.5}$ & $6^{1.4}$ & $33^{6.9}$ & $75^{19.0}$ \\
\hline Tortella tortuosa & $\mathrm{D}$ & $94^{34.7}$ & $67^{16.0}$ & $20^{5.0}$ & $18^{5.2}$ & $4^{0.9}$ & $19^{4.1}$ & $10^{2.1}$ & $65^{14.8}$ & $50^{11.1}$ & $50^{8.3}$ & . \\
\hline Fissidens dubius & D & $81^{26.4}$ & $50^{11.7}$ & $5^{1.1}$ & . & . & $41^{9.1}$ & $5^{1.1}$ & $82^{18.4}$ & . & . & $75^{22.2}$ \\
\hline Dicranum scoparium & $\mathrm{D}$ & $75^{16.7}$ & $28^{6.2}$ & $70^{26.7}$ & $44^{13.4}$ & $20^{4.9}$ & $52^{11.9}$ & $5^{1.1}$ & $18^{3.7}$ & $13^{3.5}$ & $17^{2.8}$ & $13^{3.2}$ \\
\hline Isothecium alopecuroides & D & $44^{11.1}$ & $89^{29.0}$ & $10^{2.2}$ & 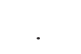 & & $63^{18.1}$ & $52^{16.9}$ & $12^{2.5}$ & $38^{8.3}$ & 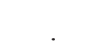 & $63^{22.2}$ \\
\hline Plagiochila asplenioides & D & $6^{1.4}$ & $6^{1.2}$ & $55^{15.6}$ & $12^{3.6}$ & $16^{4.4}$ & $52^{11.9}$ & $19^{4.2}$ & - & $31^{7.6}$ & $100^{16.7}$ & $13^{3.2}$ \\
\hline Schistidium apocarpum & D & $50^{11.8}$ & $89^{26.5}$ & $30^{8.3}$ & $26^{6.9}$ & $52^{12.0}$ & $15^{3.3}$ & $33^{7.9}$ & $53^{12.3}$ & $63^{13.9}$ & $50^{8.3}$ & $38^{9.5}$ \\
\hline Cladonia pyxidata & $\mathrm{D}$ & . & $6^{1.2}$ & $70^{15.6}$ & $56^{12.7}$ & $36^{8.0}$ & $33^{7.4}$ & & $6^{1.2}$ & $50^{11.1}$ & . & . \\
\hline Plagiochila porelloides & $\mathrm{D}$ & $88^{24.3}$ & $28^{6.8}$ & . & . & 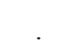 & 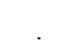 & $33^{7.4}$ & $29^{6.7}$ & . & . & $13^{3.2}$ \\
\hline
\end{tabular}




\begin{tabular}{|c|c|c|c|c|c|c|c|c|c|c|c|c|}
\hline No. of relevés & & 1 & 2 & 3 & 4 & 5 & 6 & 7 & 8 & 9 & 10 & 11 \\
\hline Cladonia coniocraea & $\mathrm{D}$ & $\cdot$ & . & $35^{7.8}$ & $53^{11.8}$ & $48^{10.7}$ & $4^{0.8}$ & $19^{4.2}$ & . & $19^{4.2}$ & $50^{8.3}$ & \\
\hline Hypnum cupressiforme & $\mathrm{D}$ & . & $11^{2.5}$ & $10^{2.2}$ & $15^{5.2}$ & $8^{4.4}$ & $15^{4.5}$ & $29^{7.9}$ & . & $31^{9.0}$ & $33^{13.9}$ & $13^{3.2}$ \\
\hline Conocephalum conicum & $\mathrm{D}$ & $75^{16.7}$ & $11^{2.5}$ & . & . & . & . & $19^{4.2}$ & . & . & . & $13^{3.2}$ \\
\hline Paraleucobryum sauteri & $\mathrm{D}$ & $88^{19.4}$ & $67^{14.8}$ & . & . & . & . & . & . & . & . & . \\
\hline Mnium thomsonii & $\mathrm{D}$ & $69^{15.3}$ & $50^{11.7}$ & . & . & . & . & $10^{2.1}$ & $6^{1.2}$ & . & . & $13^{3.2}$ \\
\hline Peltigera canina & $\mathrm{D}$ & $50^{11.1}$ & $33^{7.4}$ & $5^{1.1}$ & . & $4^{0.9}$ & . & $5^{1.1}$ & $6^{1.2}$ & . & . & . \\
\hline Cladonia digitata & $\mathrm{D}$ & $6^{1.4}$ & . & $45^{10.0}$ & $15^{3.3}$ & $20^{4.4}$ & $4^{0.8}$ & $5^{1.1}$ & . & $13^{2.8}$ & $17^{2.8}$ & . \\
\hline Atrichum undulatum & $\mathrm{D}$ & . & $17^{3.7}$ & $5^{1.1}$ & $9^{2.0}$ & . & $22^{4.9}$ & $10^{2.1}$ & . & $6^{1.4}$ & $33^{6.9}$ & $13^{3.2}$ \\
\hline Plagiomnium undulatum & $\mathrm{D}$ & . & . & $5^{1.1}$ & . & $20^{5.8}$ & $15^{3.3}$ & $43^{14.3}$ & . & . & $17^{2.8}$ & . \\
\hline Orthothecium rufescens & $\mathrm{D}$ & $31^{6.9}$ & . & . & . & . & . & . & $6^{1.2}$ & . & . & . \\
\hline Eurhynchium striatum & $\mathrm{D}$ & $50^{10.4}$ & $6^{1.2}$ & . & . & . & . & $10^{2.1}$ & . & . & . & $25^{6.3}$ \\
\hline Rhizomnium punctatum & $\mathrm{D}$ & $56^{13.9}$ & $6^{1.2}$ & $5^{1.1}$ & . & . & $7^{1.6}$ & $5^{1.1}$ & . & . & . & . \\
\hline Homalothecium philippeanum & $\mathrm{D}$ & $31^{6.9}$ & $17^{3.7}$ & . & . & . & $4^{0.8}$ & $19^{4.2}$ & . & . & . & $13^{3.2}$ \\
\hline Camptothecium lutescens & $\mathrm{D}$ & . & $6^{1.2}$ & . & . & . & $7^{1.6}$ & $33^{7.9}$ & $6^{1.3}$ & $25^{5.6}$ & . & . \\
\hline Leucobryum glaucum & $\mathrm{D}$ & $6^{1.4}$ & . & $10^{2.8}$ & . & . & . & . & $18^{3.7}$ & . & . & . \\
\hline Hylocomium splendens & $\mathrm{D}$ & $25^{5.6}$ & . & . & . & $4^{0.9}$ & $15^{3.3}$ & $19^{9.5}$ & . & . & $17^{2.8}$ & . \\
\hline Thamnobryum alopecurum & $\mathrm{D}$ & . & $11^{2.5}$ & . & . & . & $4^{0.8}$ & $19^{4.8}$ & . & $6^{1.4}$ & . & $38^{9.5}$ \\
\hline Cladonia furcata & $\mathrm{D}$ & . & . & $40^{9.4}$ & $15^{3.3}$ & . & . & . & . & . & $17^{2.8}$ & . \\
\hline Encalypta streptocarpa & $\mathrm{D}$ & $19^{4.2}$ & $6^{1.2}$ & . & . & . & . & $5^{1.1}$ & $18^{3.7}$ & . & . & . \\
\hline Bryum capillare & $\mathrm{D}$ & $13^{2.8}$ & $22^{4.9}$ & $5^{1.1}$ & . & . & . & $29^{7.4}$ & . & . & . & . \\
\hline Rhytidiadelphus triquetrus & $\mathrm{D}$ & $31^{7.6}$ & . & $5^{1.7}$ & . & . & $11^{2.5}$ & . & . & . & . & . \\
\hline Thuidium tamariscinum & $\mathrm{D}$ & $13^{2.8}$ & $11^{2.5}$ & . & . & $4^{0.9}$ & $4^{0.8}$ & $5^{1.1}$ & . & $6^{1.4}$ & . & $13^{3.2}$ \\
\hline Mnium sp. & $\mathrm{D}$ & . & $6^{1.2}$ & . & . & . & . & $24^{6.3}$ & . & . & . & . \\
\hline Plagiothecium undulatum & $\mathrm{D}$ & $25^{5.6}$ & . & $5^{1.1}$ & . & . & . & . & . & . & . & . \\
\hline Radula complanata & $\mathrm{D}$ & . & . & $15^{3.3}$ & $6^{1.3}$ & $4^{0.9}$ & . & . & . & . & . & . \\
\hline Rhytidiadelphus loreus & $\mathrm{D}$ & $31^{6.9}$ & $6^{1.2}$ & . & . & . & $7^{1.6}$ & . & . & . & . & . \\
\hline Neckera complanata & $\mathrm{D}$ & $6^{1.4}$ & . & $5^{1.1}$ & . & . & $11^{2.5}$ & $5^{1.1}$ & . & . & $17^{2.8}$ & . \\
\hline Peltigera aphthosa & $\mathrm{D}$ & . & . & . & . & . & $33^{7.4}$ & . & . & $6^{1.4}$ & . & . \\
\hline Plagiothecium sp. & $\mathrm{D}$ & $6^{1.4}$ & . & . & . & . & $22^{5.8}$ & $5^{1.1}$ & . & $6^{1.4}$ & . & . \\
\hline Eurhynchium zetterstedtii & $\mathrm{D}$ & . & . & . & . & . & $30^{7.4}$ & $5^{1.6}$ & . & . & . & . \\
\hline Plagiopus oederi & $\mathrm{D}$ & $6^{1.4}$ & . & $5^{1.1}$ & . & . & . & . & . & . & . & . \\
\hline Bartramia halleriana & $\mathrm{D}$ & $13^{2.8}$ & . & . & . & . & . & . & $6^{1.2}$ & . & . & . \\
\hline Mnium spinosum & $\mathrm{D}$ & $19^{4.2}$ & . & . & . & . & . & $5^{1.1}$ & . & $6^{1.4}$ & . & . \\
\hline Plagiothecium sylvaticum & $\mathrm{D}$ & . & . & . & . & . & $7^{1.6}$ & $5^{1.1}$ & . & $13^{2.8}$ & . & . \\
\hline Metzgeria conjugata & $\mathrm{D}$ & . & . & . & $12^{2.6}$ & . & $7^{1.6}$ & $5^{1.1}$ & . & . & . & . \\
\hline Plagiomnium cuspidatum & $\mathrm{D}$ & . & $6^{1.2}$ & . & . & . & . & $5^{1.1}$ & . & . & . & $13^{3.2}$ \\
\hline Anomodon viticulosus & $\mathrm{D}$ & . & . & . & . & . & $11^{2.9}$ & $10^{2.1}$ & . & . & . & . \\
\hline Fissidens taxifolius & $\mathrm{D}$ & . & $6^{1.2}$ & . & . & . & . & . & . & . & . & $13^{3.2}$ \\
\hline Collema flaccidum & $\mathrm{D}$ & . & . & $10^{2.2}$ & $3^{0.7}$ & $4^{0.9}$ & . & . & . & . & . & . \\
\hline Mnium orthorrhynchium & $\mathrm{D}$ & . & . & . & . & . & $11^{2.5}$ & $5^{1.1}$ & . & . & . & . \\
\hline Tetraphis pellucida & $\mathrm{D}$ & . & . & $5^{1.1}$ & $6^{1.3}$ & . & . & . & . & . & . & . \\
\hline Herzogiella seligeri & $\mathrm{D}$ & . & . & $5^{1.1}$ & . & . & . & $5^{1.1}$ & . & . & . & . \\
\hline Isothecium myurum & $\mathrm{D}$ & . & . & $5^{1.1}$ & . & . & . & $5^{1.1}$ & . & . & . & . \\
\hline Mnium marginatum & $\mathrm{D}$ & . & . & $5^{1.1}$ & . & . & . & $5^{1.1}$ & . & . & . & . \\
\hline
\end{tabular}


Table 5: Analytical table of the subassociation Omphalodo-Fagetum var. geogr. Saxifraga cuneifolia adenostyletosum glabrae subass. nova in the Trnovski gozd plateau (NW Dinaric Alps; complete linkage, Euclidian distances).

Tabela 5: Analizna tabela subasociacije Omphalodo-Fagetum var. geogr. Saxifraga cuneifolia adenostyletosum glabrae subass. nova v Trnovskem gozdu (severozahodni Dinaridi; metoda popolnega povezovanja, Evklidske razdalje).

\begin{tabular}{lllllllllllllllllll} 
Taxa & 1 & 2 & 3 & 4 & 5 & 6 & 7 & 8 & $9 *$ & 10 & 11 & 12 & 13 & 14 & 15 & 16 & 17 & 18 \\
\hline
\end{tabular}

Characteristic species of the association Omphalodo-Fagetum

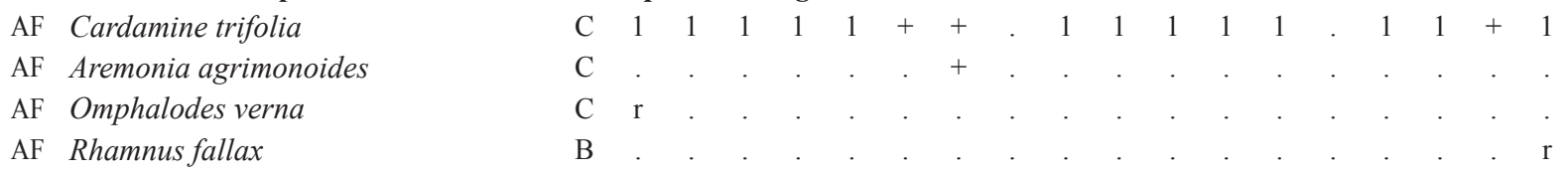

Differential species for the geographical variant Saxifraga cuneifolia

AT Paederotalutea

FS Laburnum alpinum

AT Phyteuma scheuchzeri/columnae

VP Saxifraga cuneifolia

$\begin{array}{llllllllll}\mathrm{C} & + & \cdot & \cdot & + & \cdot & \cdot & \cdot & + & + \\ \mathrm{B} & \cdot & \mathrm{r} & \cdot & 1 & + & + & \cdot & + & \\ \mathrm{C} & \cdot & \cdot & \cdot & \cdot & \cdot & + & \cdot & 1 & \cdot \\ \mathrm{C} & \cdot & + & \cdot & + & \cdot & \cdot & \cdot & + & \mathrm{r} \\ \mathrm{C} & \cdot & \cdot & \cdot & \cdot & \cdot & \cdot & \cdot & \cdot & +\end{array}$

Differential species combination for the subassociation -adenostyletosum glabrae

TR Adenostyles glabra

MA Veratrum album

$\mathrm{C} 21+11+211+1++++1+1$

MA Saxifraga rotundifolia

$\mathrm{C} 1+++1++1+++\mathrm{r}+++11+$

AF Aremonio-Fagion

Cardamine enneaphyllos

Cyclamen purpurascens

Helleborus niger

Euphorbia carniolica

$\mathrm{C}+++$

FS Fagetalia sylvaticae

Fagus sylvatica

$\begin{array}{lllllllllllllllllllll}\mathrm{C} & 1 & 1 & 1 & 1 & 1 & + & 1 & 1 & 1 & 1 & 1 & 1 & . & 1 & 1 & 1 & 1 & 1\end{array}$

Prenanthes purpurea

$\mathrm{C}+\cdot++++++$

$\mathrm{C} \cdot+\cdot+1$

Acer pseudoplatanus

Galeobdolon flavidum

Dryopteris filix-mas

Mycelis muralis

Neottia nidus-avis

Paris quadrifolia

Carex sylvatica

Phyteuma spicatum/coeruleum

Galium odoratum

Cradamine bulbifera

Epilobium montanum

Festuca altissima

Polystichum aculeatum

Daphne mezereum

Lilium martagon

Sanicula europaea

Galium laevigatum

Mercurialis perennis

Actaea spicata

\begin{tabular}{|c|c|c|c|c|c|c|c|c|c|c|c|c|c|c|c|c|c|}
\hline A & 4 & 5 & 5 & 5 & 5 & 5 & 3 & 5 & 5 & 5 & 5 & 3 & 3 & 5 & 5 & 5 & 5 \\
\hline B & + & + & 1 & 2 & 1 & + & + & + & + & 1 & 1 & 3 & 3 & 1 & 2 & + & . \\
\hline $\mathrm{C}$ & + & 1 & 1 & + & 1 & 1 & + & 1 & 1 & 1 & 1 & + & 1 & . & 1 & 1 & 1 \\
\hline $\mathrm{C}$ & + & 1 & 1 & 1 & 1 & + & + & 1 & + & + & 1 & & + & + & + & 1 & \\
\hline A & 1 & 1 & + & + & + & + & + & + & + & + & . & 1 & + & 1 & + & 1 & 1 \\
\hline B & + & + & 1 & 1 & 1 & . & + & + & + & 1 & 1 & 1 & 1 & 1 & 1 & + & + \\
\hline $\mathrm{C}$ & 1 & 1 & 2 & 1 & 1 & 1 & . & 1 & 1 & 1 & . & . & 1 & 1 & 1 & 1 & + \\
\hline $\mathrm{C}$ & + & 1 & 1 & + & + & . & 1 & . & 1 & 1 & 1 & + & + & 1 & 1 & 1 & 1 \\
\hline $\mathrm{C}$ & . & + & 1 & + & + & . & + & . & + & 1 & + & + & 1 & 1 & 1 & 1 & 1 \\
\hline C & + & + & . & 1 & 1 & . & . & . & + & + & + & + & + & + & + & $T$ & 1 \\
\hline C & . & + & + & + & + & . & . & + & + & + & + & $\mathrm{r}$ & + & + & + & . & + \\
\hline $\mathrm{C}$ & 1 & + & . & . & + & . & + & . & + & . & + & + & + & + & + & + & + \\
\hline $\mathrm{C}$ & + & + & + & + & 1 & . & + & . & 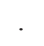 & + & . & 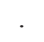 & + & + & + & + & . \\
\hline $\mathrm{C}$ & + & + & + & + & + & . & . & . & + & + & 1 & 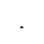 & + & . & . & + & + \\
\hline $\mathrm{C}$ & 1 & . & 1 & . & . & . & + & . & . & 1 & + & . & + & 1 & 1 & 1 & + \\
\hline $\mathrm{C}$ & + & . & + & . & . & . & . & . & . & + & + & + & . & 1 & 1 & + & + \\
\hline $\mathrm{C}$ & 1 & + & + & . & . & . & + & . & $\mathrm{r}$ & + & . & 1 & + & . & + & . & + \\
\hline $\mathrm{C}$ & . & . & + & . & . & . & . & . & + & + & + & . & + & + & + & + & + \\
\hline $\mathrm{C}$ & + & + & + & . & . & . & + & . & + & . & . & + & + & . & + & + & + \\
\hline B & . & + & . & . & + & . & + & + & . & . & + & . & + & . & . & . & + \\
\hline C & + & + & + & . & + & . & . & . & . & . & . & . & + & . & + & + & + \\
\hline C & . & . & + & $\cdot$ & + & . & . & 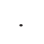 & . & + & + & . & . & + & . & + & + \\
\hline $\mathrm{C}$ & . & . & + & + & + & . & . & + & + & . & 1 & . & . & . & . & . & . \\
\hline C & 2 & . & . & . & . & + & 2 & 1 & + & . & . & . & . & . & . & - & 1 \\
\hline C & + & + & . & . & . & . & . & . & . & . & . & $\mathrm{r}$ & . & . & . & + & + \\
\hline
\end{tabular}


Taxa

Scrophularia nodosa

Symphytum tuberosum

Adoxa moschatellina

Circaea alpina

Stellaria montana

Lonicera alpigena

Poa nemoralis

Carex pilosa

Fraxinus excelsior

Campanula trachelium

Chrysosplenium alternifolium

Circaea lutetiana

Epipactis helleborine

Melica nutans

Milium effusum

Myosotis sylvatica

Phyllitis scolopendrium

Salvia glutinosa

QF Querco-Fagetea

Anemone nemorosa

Carex digitata

QP Quercetalia pubescentis

Sorbus aria

EP Erico-Pinetea

Calamagrostis varia

Carex alba

Cirsium erisithales

VP Vaccinio-Piceetea

Abies alba

Calamagrostis arundinacea

Oxalis acetosella

Veronica urticifolia

Gentiana asclepiadea

Aposeris foetida

Maianthemum bifolium

Dryopteris dilatata

Vaccinium myrtillus

Luzula sylvatica/sylvatica

Picea abies

Dryopteris expansa

Gymnocarpium dryopteris

Rosa pendulina

Solidago virgaurea

Huperzia selago 
Taxa

$\begin{array}{llllllllllllllllll}1 & 2 & 3 & 4 & 5 & 6 & 7 & 8 & 9 * & 10 & 11 & 12 & 13 & 14 & 15 & 16 & 17 & 18\end{array}$

Valeriana tripteris

Hieracium murorum

C

MA Mulgedio-Aconitetea

Polygonatum verticillatum

Athyrium filix-femina

Senecio ovatus

Ranunculus platanifolius

Heracleum sphondylium

Adenostyles alliariae

Geranium robertianum

Senecio cacaliaster

Urtica dioica

Aconitum degenii/paniculatum

Aconitum lycoctonum

Salix appendiculata

ES Elyno-Seslerietea

Aster bellidiastrum

Carex ferruginea

Sesleria caerulea/calcaria

AT Asplenietea tricohmanis

Cystopteris fragilis

Asplenium trichomanes

Asplenium viride

Carex brachystachys

Moehringia muscosa

Sedum hispanicum

Other taxa

Rubus idaeus

Sorbus aucuparia

Galeopsis speciosa

Fragaria vesca

Lichens and mosses

Ctenidium molluscum

Isothecium alopecuroides

Schistidium apocarpum

Paraleucobryum sauteri

Tortella tortuosa

Fissidens dubius

Mnium thomsonii

Polytrichum formosum

Peltigera canina

Dicranum scoparium

Plagiochila porelloides

Bryum capillare

Atrichum undulatum

Homalothecium philippeanum

Neckera crispa

Conocephalum conicum

Hypnum cupressiforme

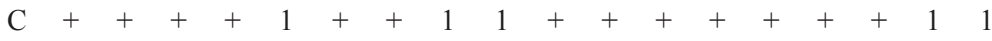

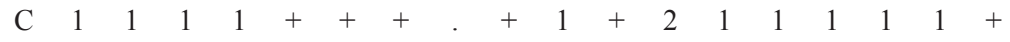

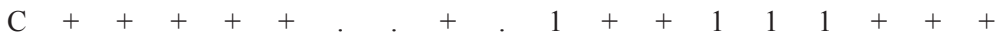

$\mathrm{C}+++$ r. . $\mathrm{r}++\mathrm{r}+\mathrm{r}+++$.

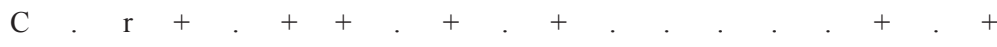

$\mathrm{C}$

$\mathrm{C}$

$\mathrm{C}$

$\mathrm{C}$

C

$\mathrm{C}$

B

C

$\mathrm{C}$

C

$\mathrm{C}$
$\mathrm{C}$
$\mathrm{C}$
$\mathrm{C}$
$\mathrm{C}$

\begin{tabular}{|c|c|c|c|c|c|c|c|c|c|c|c|c|c|c|}
\hline B & . & . & 1 & 1 & 1 & + & + & $\mathrm{r}$ & + & 1 & 1 & 1 & 1 & \\
\hline B & . & + & . & + & + & + & + & $\cdot$ & . & + & . & & & \\
\hline $\mathrm{C}$ & + & . & + & 1 & + & 1 & . & + & + & & 1 & & & \\
\hline $\mathrm{C}$ & $\cdot$ & · & + & $\cdot$ & $\cdot$ & . & . & & . & 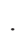 & & & & \\
\hline $\mathrm{C}$ & $\cdot$ & · & . & $\cdot$ & . & . & . & . & . & . & . & & - & \\
\hline
\end{tabular}

Thamnobryum alopecurum

\begin{tabular}{|c|c|c|c|c|c|c|c|c|c|c|c|c|c|c|c|c|}
\hline D & 1 & 1 & 1 & 1 & 1 & + & + & 2 & 2 & 1 & 2 & 1 & 2 & 1 & 1 & \\
\hline D & 1 & 1 & + & + & + & . & + & . & 2 & 1 & 1 & + & 1 & 1 & 1 & \\
\hline D & 1 & 1 & + & 1 & 1 & + & 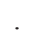 & 1 & 1 & + & 1 & 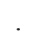 & + & + & 1 & \\
\hline D & + & + & + & + & . & + & . & + & 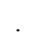 & + & + & . & . & + & 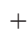 & \\
\hline D & + & + & + & + & 1 & . & . & . & . & + & + & + & + & $\cdot$ & & \\
\hline D & + & + & + & + & + & . & 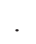 & . & + & $v^{\prime}$ & . & . & + & 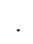 & $e^{\circ}$ & \\
\hline D & + & + & . & . & . & + & . & + & $\theta^{\prime}$ & . & + & 1 & + & 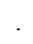 & $\theta^{\circ}$ & \\
\hline D & + & . & . & + & + & + & . & + & . & . & . & . & + & 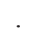 & & \\
\hline D & + & + & . & . & . & . & . & . & . & . & + & . & + & . & + & \\
\hline D & + & . & . & + & + & . & . & + & . & . & . & . & . & ${ }^{\circ}$ & • & \\
\hline D & + & . & . & . & . & . & . & . & . & . & . & + & + & . & + & \\
\hline D & . & + & . & . & . & . & . & . & . & . & . & . & + & . & + & \\
\hline D & . & . & . & . & . & . & . & . & . & . & . & . & + & . & + & \\
\hline D & . & + & . & . & . & . & . & . & + & . & . & . & . & . & • & \\
\hline D & + & . & . & . & . & . & . & . & + & . & + & . & . & . & . & \\
\hline D & . & . & . & . & . & . & . & . & . & . & . & + & + & . & . & \\
\hline D & . & . & . & . & . & . & $\cdot$ & . & . & . & . & + & . & . & . & \\
\hline D & + & + & . & . & . & . & $\cdot$ & $\cdot$ & . & · & . & . & . & . & • & \\
\hline$D$ & + & . & . & . & . & . & . & . & . & & + & . & . & . & . & \\
\hline
\end{tabular}


Table 6: Analytical table of the subassociation Omphalodo-Fagetum var. geogr. Saxifraga cuneifolia saxifragetosum cuneifoliae subass. nova in the Trnovski gozd plateau (NW Dinaric Alps; complete linkage, Euclidian distances).

Tabela 6: Analizna tabela subasociacije Omphalodo-Fagetum var. geogr. Saxifraga cuneifolia saxifragetosum cuneiofliae subass. nova v Trnovskem gozdu (severozahodni Dinaridi; metoda popolnega povezovanja, Evklidske razdalje).

\begin{tabular}{|c|c|c|c|c|c|c|c|c|c|c|c|c|c|c|c|c|c|c|c|c|c|c|}
\hline & Taxa & & 1 & 2* & 3 & 4 & 5 & 6 & 7 & 8 & 9 & 10 & 11 & 12 & 13 & 14 & 15 & 16 & 17 & 18 & 19 & 20 \\
\hline \multicolumn{23}{|c|}{ Characteristic species of the association Omphalodo-Fagetum } \\
\hline $\mathrm{AF}$ & Cardamine trifolia & $\mathrm{C}$ & 1 & 1 & + & 1 & 1 & + & + & + & 1 & 1 & ${ }^{\circ}$ & . & + & + & 1 & 2 & 2 & + & . & \\
\hline $\mathrm{AF}$ & Omphalodes verna & $\mathrm{C}$ & . & 2 & + & 2 & 1 & . & 2 & . & 2 & . & . & . & . & . & 2 & 1 & . & . & . & \\
\hline $\mathrm{AF}$ & Aremonia agrimonoides & $\mathrm{C}$ & . & . & . & + & . & . & . & . & + & . & . & . & . & + & . & . & + & . & . & \\
\hline $\mathrm{AF}$ & Calamintha grandiflora & $\mathrm{C}$ & . & $\cdot$ & · & . & $\cdot$ & $\cdot$ & + & . & . & . & . & . & . & . & . & . & . & . & . & \\
\hline \multicolumn{23}{|c|}{ Differential species for the geographical variant Saxifraga cuneifolia } \\
\hline VP & Saxifraga cuneifolia & $\mathrm{C}$ & 1 & + & 1 & 1 & 2 & 1 & . & 1 & 1 & 2 & 1 & 2 & + & + & . & . & 1 & 2 & + & + \\
\hline AT & Paederota lutea & $\mathrm{C}$ & . & 2 & 2 & . & . & 1 & . & 2 & 2 & 1 & 2 & + & . & . & . & . & . & . & . & \\
\hline AT & Phyteuma scheuchzeri/columnae & $\mathrm{C}$ & 1 & 1 & + & . & . & . & . & . & $v^{\prime}$ & . & . & . & . & + & . & . & . & . & . & \\
\hline \multirow{2}{*}{\multicolumn{2}{|c|}{ FS Laburnum alpinum }} & B & . & . & . & . & $\cdot$ & . & . & $\cdot$ & · & . & . & . & . & + & . & . & . & . & . & \\
\hline & & $\mathrm{C}$ & . & . & . & . & . & . & . & . & . & $\cdot$ & . & . & + & + & . & . & . & . & $\cdot$ & \\
\hline
\end{tabular}

Differential species for the subassociation -saxifragetosum cuneifoliae

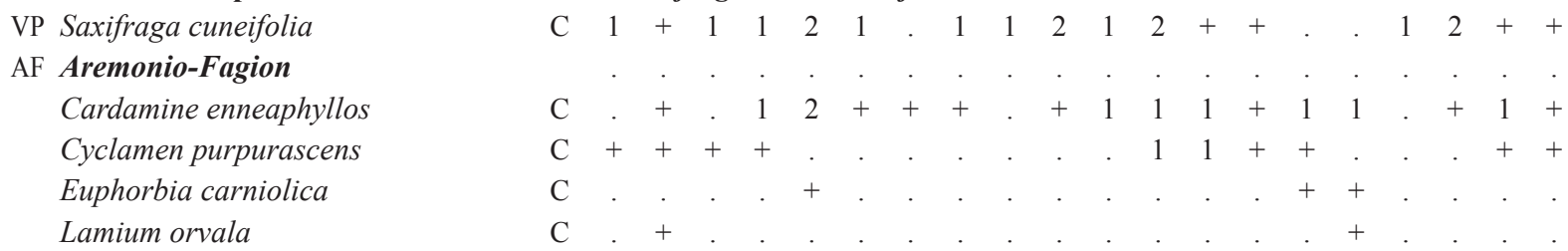

FS Fagetalia sylvaticae

Fagus sylvatica

Prenanthes purpurea

Daphne mezereum

Dryopteris filix-mas

Acer pseudoplatanus

Mycelis muralis

Paris quadrifolia

Lonicera alpigena

Epilobium montanum

Polystichum aculeatum

Galeobdolon flavidum

Actaea spicata

Galium laevigatum

Lilium martagon

Festuca altissima

Mercurialis perennis

Galium odoratum

Sambucus nigra

Aruncus dioicus

Phyteuma spicatum

Lathyrus vernus/flaccidus

Lathyrus vernus/vernus

Phyteuma spicatum/coeruleum

\begin{tabular}{|c|c|c|c|c|c|c|c|c|c|c|c|c|c|c|c|c|c|c|c|c|}
\hline A & 3 & 1 & 2 & + & 3 & 2 & 4 & 2 & 1 & 2 & 3 & 1 & 4 & 4 & 4 & 4 & 4 & & 3 & 3 \\
\hline B & 2 & 1 & 2 & 1 & 2 & 2 & 2 & 2 & 2 & & & . & + & . & 1 & 2 & & & + & 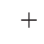 \\
\hline $\mathrm{C}$ & + & + & + & + & 1 & + & 1 & + & + & + & 2 & + & + & + & 2 & 1 & 1 & & + & \\
\hline $\mathrm{C}$ & + & 1 & 1 & 1 & 1 & + & 1 & 1 & 1 & + & + & + & 1 & + & 1 & 3 & 1 & & + & \\
\hline B & 1 & 1 & + & + & + & + & + & + & 1 & + & + & + & + & 1 & 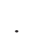 & - & + & & + & + \\
\hline $\mathrm{C}$ & + & 1 & 1 & 1 & + & + & + & + & + & + & . & + & + & + & + & + & 1 & & . & \\
\hline A & . & . & + & . & + & . & . & 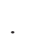 & . & & 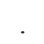 & . & . & . & . & 1 & 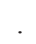 & & . & \\
\hline B & . & . & + & + & + & + & 1 & . & . & . & . & . & . & . & + & 1 & 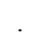 & & . & \\
\hline $\mathrm{C}$ & + & + & + & + & + & + & 2 & . & + & . & . & + & + & . & + & & + & + & . & \\
\hline $\mathrm{C}$ & . & 1 & + & 1 & + & + & + & 1 & + & + & 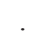 & + & + & + & 1 & . & + & & . & \\
\hline C & + & . & + & + & + & + & + & + & . & + & . & + & + & . & + & + & + & + & . & $\cdot$ \\
\hline B & 2 & . & + & . & 1 & . & . & 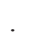 & 2 & + & . & . & + & + & 1 & + & + & 2 & . & + \\
\hline $\mathrm{C}$ & . & + & + & + & + & + & + & . & + & $\cdot$ & . & . & . & + & + & . & 1 & T & . & . \\
\hline C & + & 1 & + & + & . & + & + & 1 & + & . & . & . & . & + & + & . & . & & . & \\
\hline C & ${ }^{\circ}$ & + & + & + & + & + & + & ${ }^{\circ}$ & . & . & . & . & . & . & + & 1 & + & & . & $\cdot$ \\
\hline $\mathrm{C}$ & + & + & + & + & + & 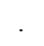 & + & 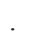 & . & + & $\cdot$ & $\cdot$ & . & . & . & . & + & & . & . \\
\hline $\mathrm{C}$ & . & . & . & . & . & 1 & . & . & . & 1 & - & . & 1 & 2 & . & & 1 & 1 & + & 1 \\
\hline $\mathrm{C}$ & . & . & + & . & . & . & . & + & . & + & + & + & + & + & . & . & . & & . & + \\
\hline $\mathrm{C}$ & . & . & . & . & . & 1 & 2 & + & . & ${ }^{\circ}$ & . & . & . & . & . & . & 3 & + & + & + \\
\hline $\mathrm{C}$ & . & 1 & + & 1 & . & . & 1 & . & . & . & . & . & . & . & . & . & 1 & 2 & . & 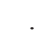 \\
\hline $\mathrm{C}$ & . & . & + & . & . & . & + & . & . & . & 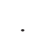 & . & . & + & . & & 1 & & . & . \\
\hline $\mathrm{C}$ & + & + & + & . & . & . & + & . & . & . & . & . & + & . & . & . & . & & . & . \\
\hline $\mathrm{C}$ & . & + & + & . & $\mathrm{r}$ & . & $\cdot$ & . & + & . & . & . & . & . & . & . & . & & . & . \\
\hline $\mathrm{C}$ & . & . & . & . & . & . & . & + & . & + & . & + & . & + & . & . & . & & . & . \\
\hline $\mathrm{C}$ & . & . & . & . & . & . & . & . & . & . & & . & + & + & . & . & + & & . & . \\
\hline $\mathrm{C}$ & . & . & . & . & . & . & . & $\cdot$ & . & . & & . & + & + & . & . & 1 & & . & \\
\hline $\mathrm{C}$ & & . & 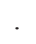 & . & 2 & . & . & 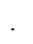 & . & . & . & . & . & . & 2 & + & . & & . & \\
\hline
\end{tabular}


Viola reichenbachiana Adoxa moschatellina

QP Quercetalia pubescentis

Sorbus aria

Sesleria autumnalis

QF Querco-Fagetea

Anemone nemorosa

Carex digitata

Hepatica nobilis

Anemone x pittonii

Cruciata glabra

EP Erico-Pinetea

Cirsium erisithales

Rhododendron hirsutum

Rubus saxatilis

VP Vaccinio-Piceetea

Abies alba

Gentiana asclepiadea

Calamagrostis arundinacea

Rosa pendulina

Clematis alpina

Picea abies

Solidago virgaurea

Valeriana tripteris

Maianthemum bifolium

Oxalis acetosella

Huperzia selago

Veronica urticifolia

Homogyne sylvestris

Vaccinium myrtillus

Lonicera nigra

Luzula luzuloides

Dryopteris dilatata

Hieracium murorum

Phegopteris connectilis

Luzula sylvatica/sylvatica

Polystichum lonchitis

Gymnocarpium dryopteris

Vaccinium vitis-idaea

Aposeris foetida

Dryopteris expansa

Lycopodium annotinum

MA Mulgedio-Aconitetea

Polygonatum verticillatum

Ranunculus platanifolius

Veratrum album
$\begin{array}{ll}\mathrm{C} & + \\ \mathrm{C} & +\end{array}$

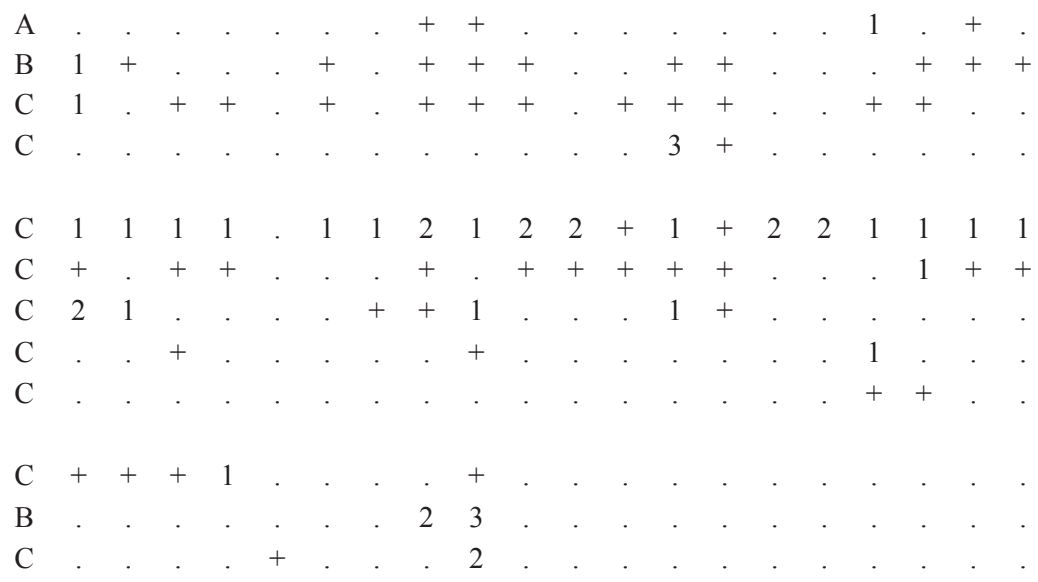

$\begin{array}{lllllllllllllllllllll}\mathrm{A} & 2 & 2 & 2 & 2 & 1 & + & 3 & 1 & 1 & 3 & 1 & 2 & 1 & 1 & 2 & 2 & 1 & 1 & 2 & 1\end{array}$

$\begin{array}{lllllllllllllllllllll}\mathrm{B} & 1 & 2 & 2 & 1 & 2 & 2 & 3 & 1 & 2 & . & . & + & + & 2 & & + & + & +\end{array}$

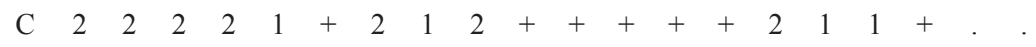

$\mathrm{C} 1+111++11+++++11+11+$

$\begin{array}{lllllllllllllllllllll}\mathrm{C} & 3 & 2 & 3 & 4 & 2 & 2 & 2 & . & 2 & 4 & 4 & 4 & 1 & 2 & 2 & 2 & 3 & 4 & 2 & 2\end{array}$

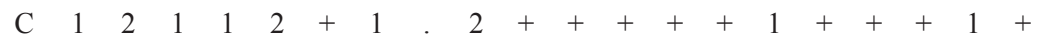

$\begin{array}{llllllllllllllllllllll}\mathrm{C} & 2 & 2 & 3 & 1 & 1 & 3 & 1 & 2 & 3 & 3 & 2 & 3 & 1 & 2 & . & . & 1 & 2 & 2 & 1\end{array}$

A. $\begin{array}{lllllllllllllllll} & 3 & 3 & 2 & 3 & 2 & 2 & 2 & 2 & + & 1 & 2 & + & 1 & 1 & 1 & \end{array}$

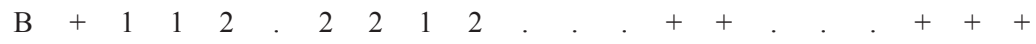

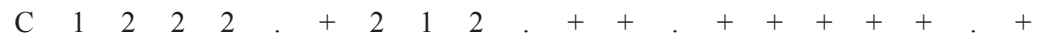

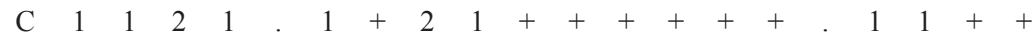

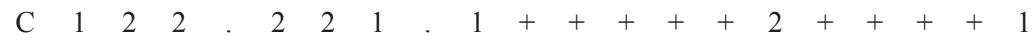

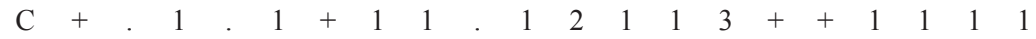

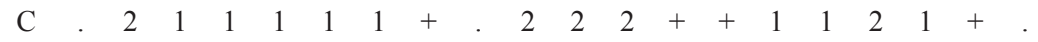

$\mathrm{C} \quad 111+$. $1+1+++++$ + + . +

$\mathrm{C} 11+$. $21+2++$ + + + $121++$. .

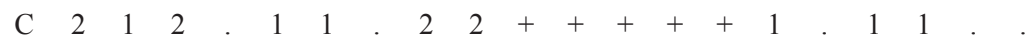

$\begin{array}{lllllllllllllllllllllll}\mathrm{C} & 3 & . & 1 & 2 & 3 & 4 & 3 & + & 3 & . & + & + & . & . & 4 & 3 & . & 1 & . & . \\ \mathrm{B} & 1 & 1 & + & 1 & + & + & . & . & 1 & . & . & . & + & . & + & 1 & + & + & . & \end{array}$.

$\mathrm{C} . \quad 1+. \quad . \quad . \quad+\quad+1++. \quad 32+1$

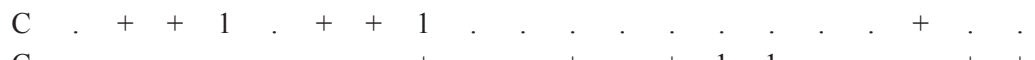

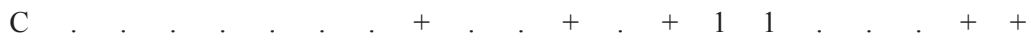

$\mathrm{C} .+. .1++1++$

$\mathrm{C} \cdot . \quad . \quad+\quad 1.4 .+$

$\mathrm{C} \cdot+++++. \quad 1$

$\mathrm{C} \cdot .+{ }^{2} \cdot+\cdot+$

$\mathrm{C}+$. $. \quad . \quad 1$. 1

C

C

C

$\mathrm{C}+++111++++11+2.232+1$

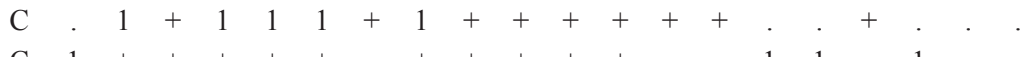


Taxa

Athyrium filix-femina

Senecio ovatus

Salix appendiculata

Doronicum austriacum

Geranium robertianum

Phyteuma ovatum

Urtica dioica

AT Asplenietea trichomanis Asplenium viride

Asplenium trichomanes

Cystopteris fragilis

Moehringia muscosa

Asplenium ruta-muraria

Polypodium vulgare

Cystopteris montana

TR Thlaspietea rotundifolii Adenostyles glabra

Gymnocarpium robertianum

Other taxa

Sorbus aucuparia

Rubus idaeus

Fragaria vesca

Spiraea chamaedryfolia

Solanum dulcamara

Sambucus racemosa

Lichens and mosses

Ctenidium molluscum

Cladonia pyxidata

Dicranum scoparium

Plagiochila asplenioides

Neckera crispa

Cladonia digitata

Cladonia furcata

Cladonia coniocraea

Grimmia pulvinata

Polytrichum formosum

Tortella tortuosa

Radula complanata

Collema flaccidum

Hypnum cupressiforme

Isothecium alopecuroides

Leucobryum glaucum

Plagiothecium laetum $\begin{array}{llllllllllllllllllll}1 & 2 * & 3 & 4 & 5 & 6 & 7 & 8 & 9 & 10 & 11 & 12 & 13 & 14 & 15 & 16 & 17 & 18 & 19 & 20\end{array}$

$\begin{array}{llll}\mathrm{C} & + & + & + \\ \mathrm{C} & + & + & + \\ \mathrm{B} & + & + & + \\ \mathrm{C} & \cdot & \cdot & \cdot \\ \mathrm{C} & \cdot & + & \cdot \\ \mathrm{C} & \cdot & \cdot & + \\ \mathrm{C} & \cdot & \cdot & .\end{array}$

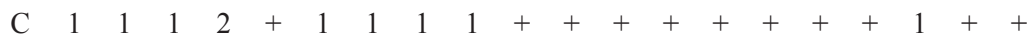

$\mathrm{C}+1++++++1++.+.+.+.+$.

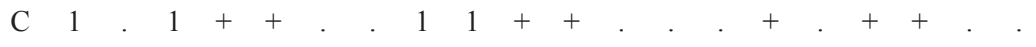

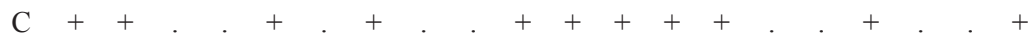

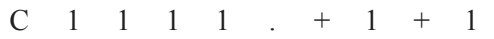

$\mathrm{C}++$

$\mathrm{C}$

$\mathrm{C} .++1 .+. \quad . \quad 1++1+++1++$ $\mathrm{C}++.+. \quad . \quad 1+$

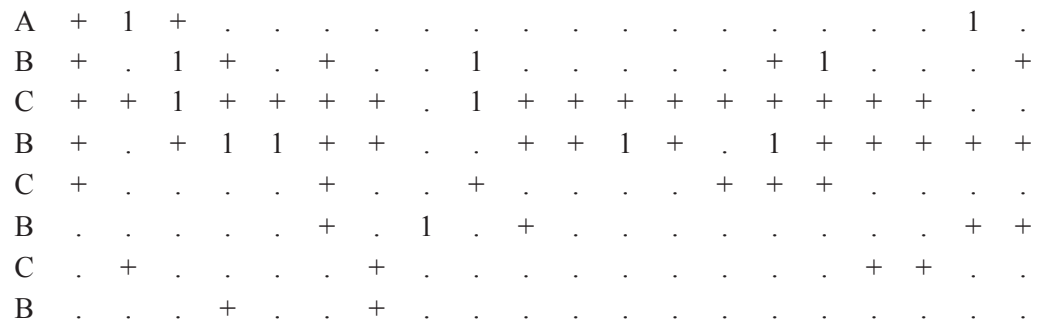

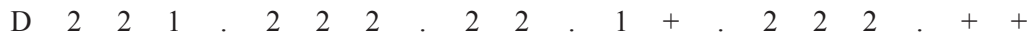

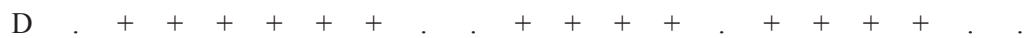

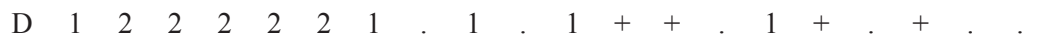

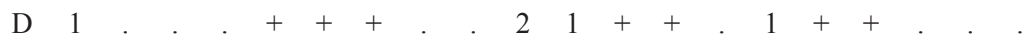

$\mathrm{D} .2 .2 .1+2 .+2.4 .2 .+$

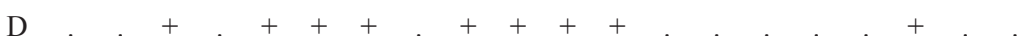

$\mathrm{D}++.++1+$

D. . . . . + .

$\mathrm{D} 1 \ldots+$

$\mathrm{D} . \quad . \quad \begin{array}{llll}1 & 2 & . & +\end{array}$

$\mathrm{D}+$. . . . +

$\mathrm{D}$. . . ++

$\mathrm{D} . .+.+$.

D . . . . +

D . $1+$

D 


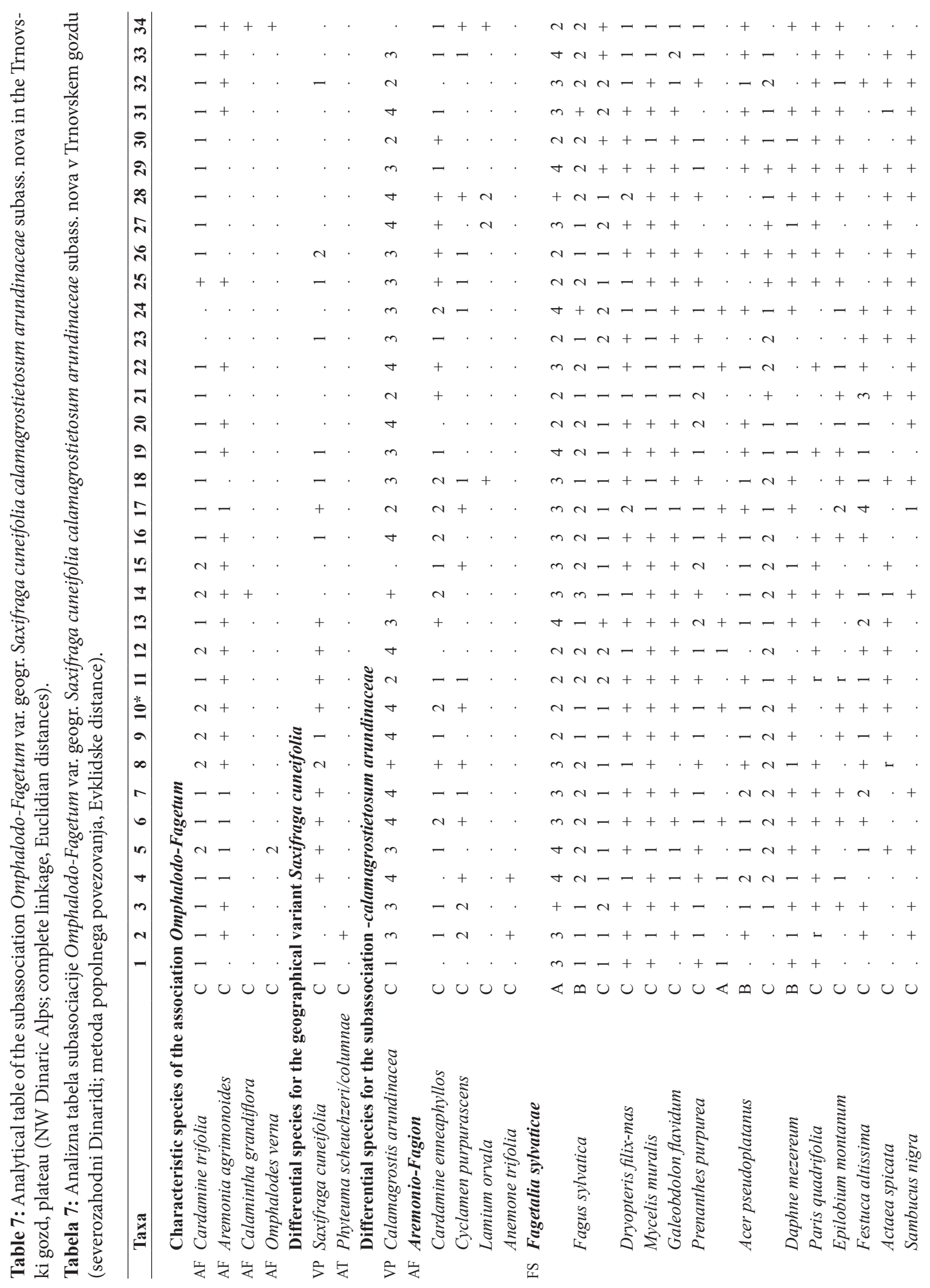



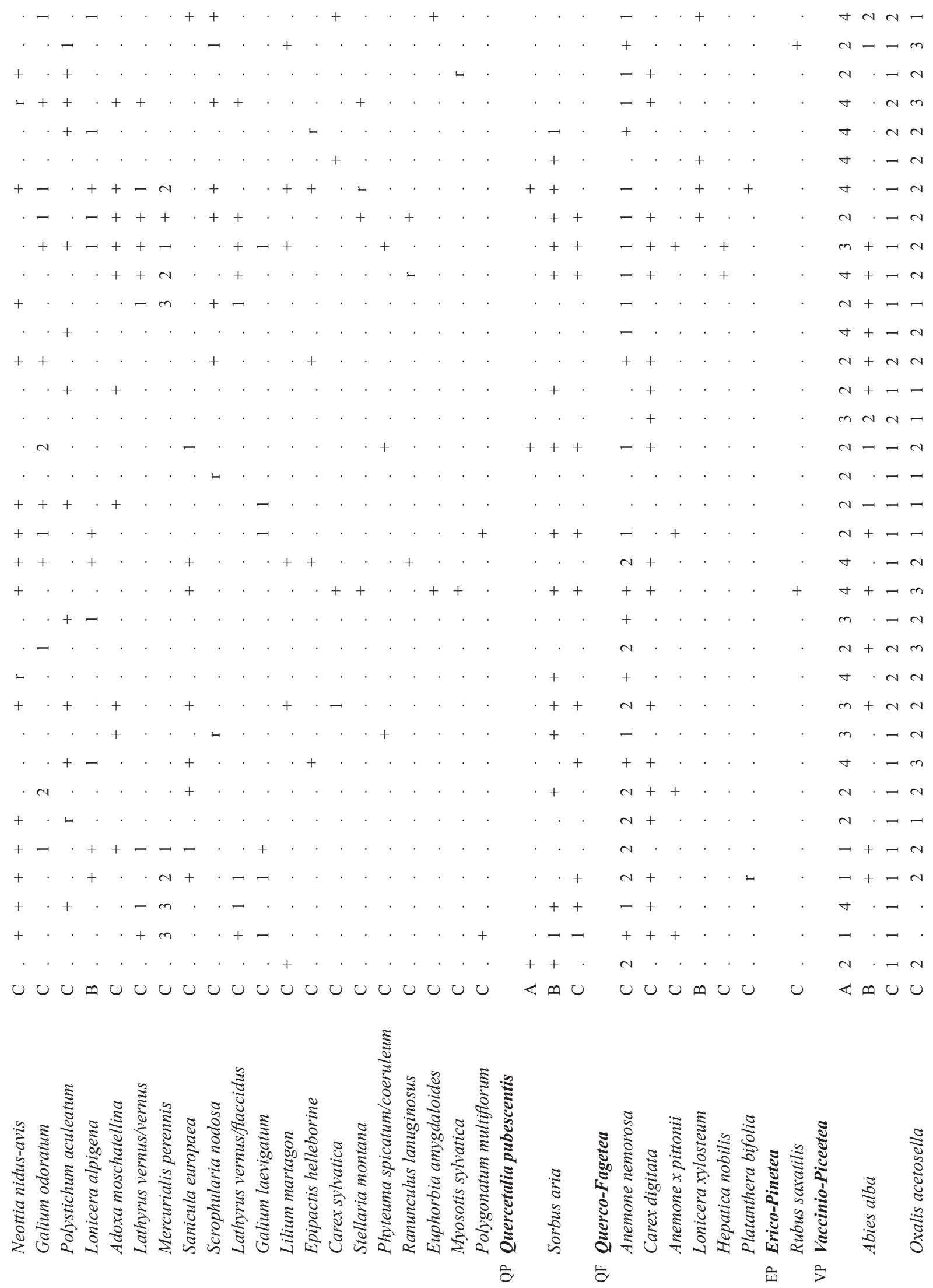

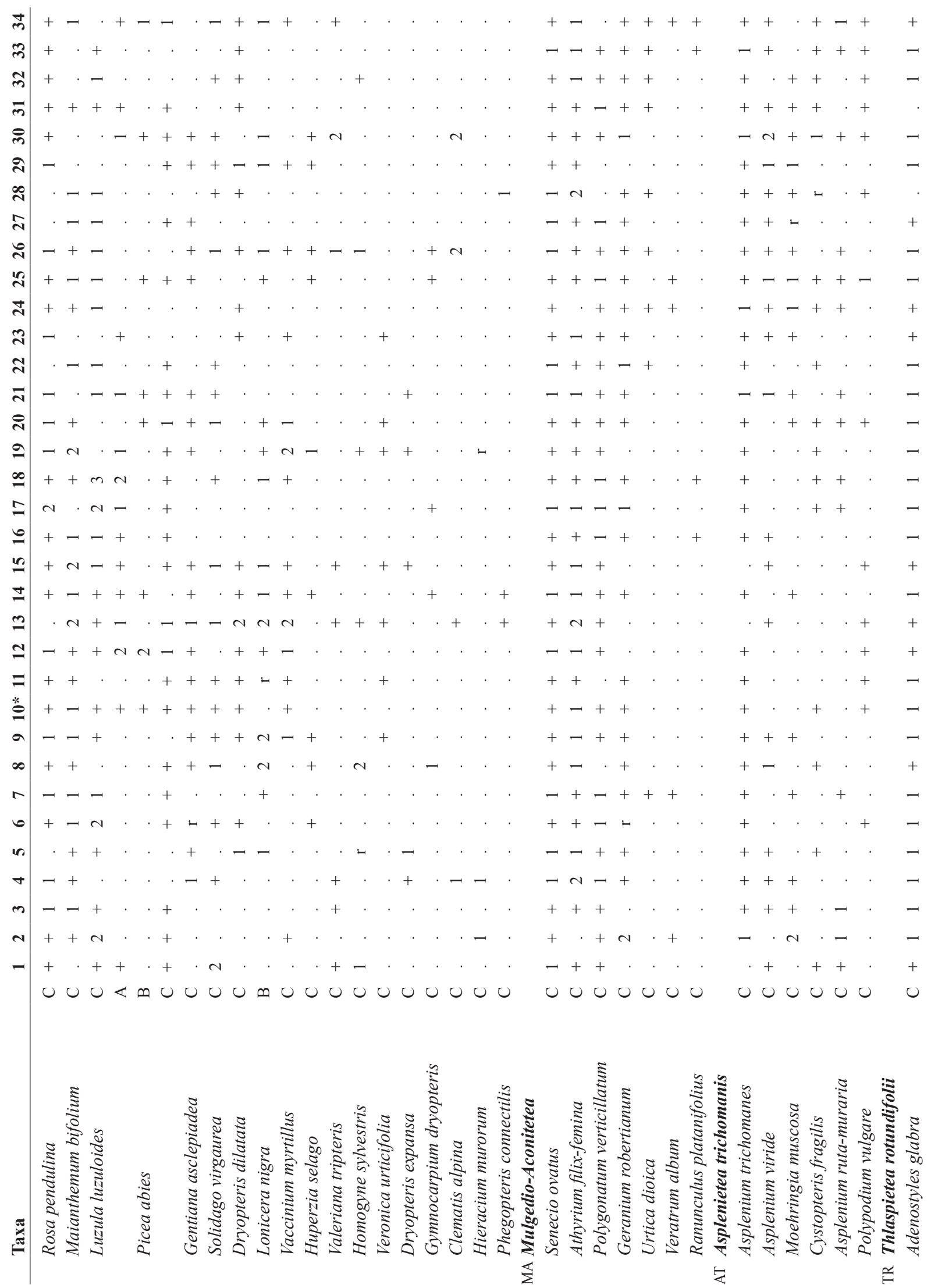

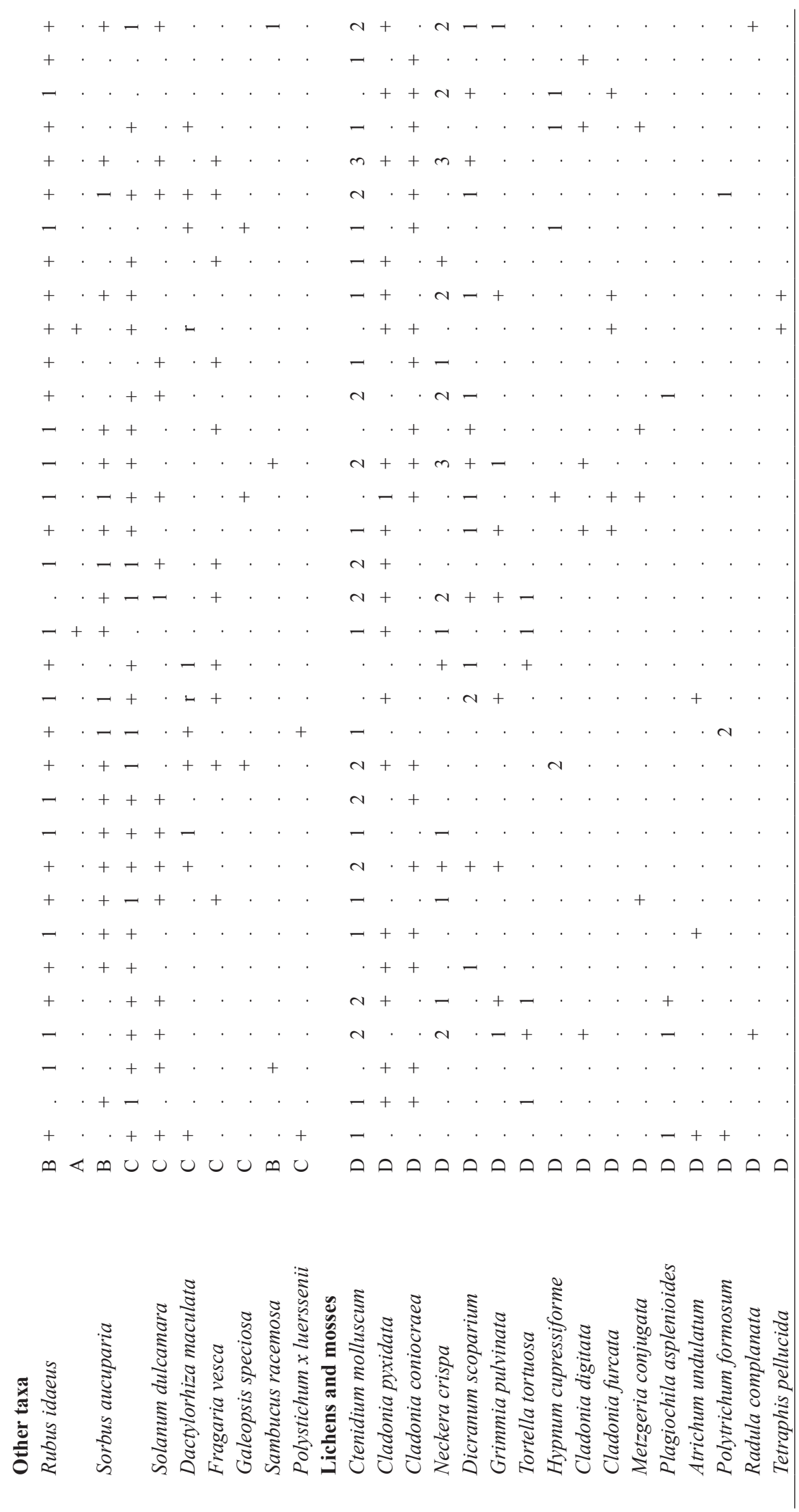
Table 8: Analytical table of the subassociation Omphalodo-Fagetum var. geogr. Saxifraga cuneifolia festucetosum altissimae (I) subass. nova in the Trnovski gozd plateau (NW Dinaric Alps; complete linkage, Euclidian distances).

Tabela 8: Analizna tabela subasociacije Omphalodo-Fagetum var. geogr. Saxifraga cuneifolia festucetosum altissimae (I) subass. nova v Trnovskem gozdu (severozahodni Dinaridi; metoda popolnega povezovanja, Evklidske razdalje).

\begin{tabular}{llllllllllllllllllllllllll} 
Taxa & 1 & 2 & 3 & 4 & 5 & 6 & 7 & 8 & 9 & 10 & 11 & 12 & 13 & $14 *$ & 15 & 16 & 17 & 18 & 19 & 20 & 21 & $22 *$ & 23 & 24 & 25 \\
\hline
\end{tabular}

Characteristic species of the association Omphalodo-Fagetum

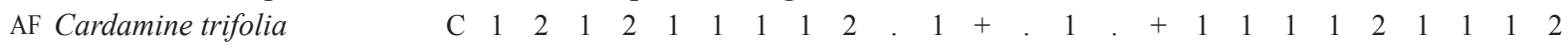

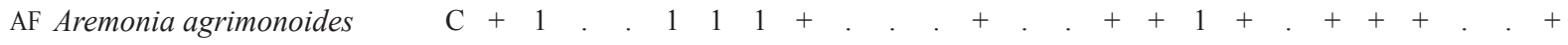

Differential species for the geographical variant Saxifraga cuneifolia

VP Saxifraga cuneifolia

AT Paederota lutea

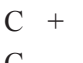

Differential species for the subassociation -festucetosum altissimae

$\begin{array}{llllllllllllllllllllllllllll}\text { FS Festuca altissima } & \mathrm{C} & 2 & 3 & 4 & 2 & 3 & 3 & 3 & 3 & 3 & 1 & 1 & 2 & 1 & 3 & 2 & 3 & 4 & 4 & + & 3 & 2 & 3 & + & 2\end{array}$

Differential species combination for the variants

VP Calamagrostis arundinacea

AF Lamium orvala

FS Cardamine bulbifera

FS Cardamine impatiens

VP Picea abies

MA Saxifraga rotundifolia

VP Saxifraga cuneifolia

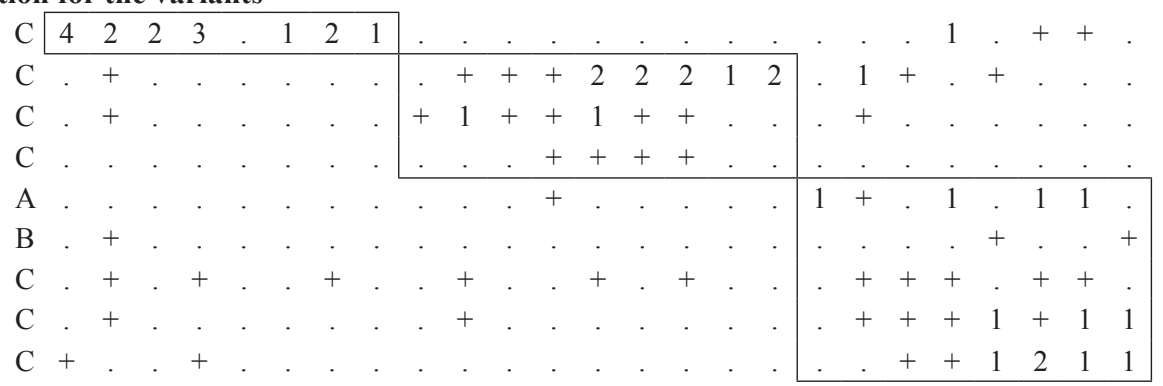

AF Aremonio-Fagion

Cardamine enneaphyllos

$\begin{array}{lllllllllllllllllllllllll}\mathrm{C} & 3 & 1 & 2 & + & 1 & . & . & 1 & 2 & 2 & 3 & 2 & 2 & 1 & 1 & 1 & 1 & 1 & 1 & 2 & 2 & 3 & 1 & 1\end{array}$.

Anemone trifolia

Euphorbia carniolica

Rhamnus fallax

$\mathrm{C}$

$\mathrm{C}$

FS Fagetalia sylvaticae

Fagus sylvatica

$\begin{array}{llllllllllllllllllllllllll}\mathrm{A} & 3 & 4 & 3 & 4 & 3 & 3 & 3 & 4 & 4 & 4 & 3 & 4 & 2 & 2 & 3 & 3 & 4 & 3 & 2 & 2 & 4 & 4 & 3 & 3 & 3\end{array}$

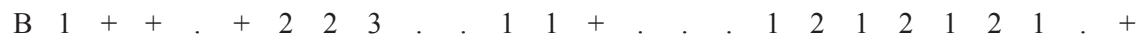

Dryopteris filix-mas

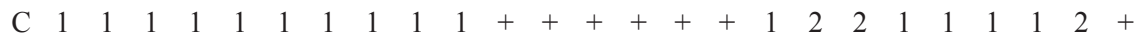

Acer pseudoplatanus

$\mathrm{C}++1+++11+++221++12+++2211$

Paris quadrifolia

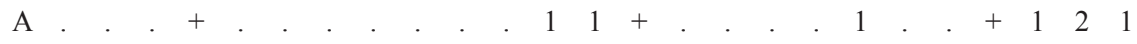

Paris quadrifolia

Galium odoratum

Mycelis muralis

Galeobdolon flavidum

Prenanthes purpurea

Stellaria montana

Actaea spicata

Daphne mezereum

Sambucus nigra

Neottia nidus-avis

Milium effusum

Epilobium montanum

Sanicula europaea

Viola reichenbachiana

Adoxa moschatellina

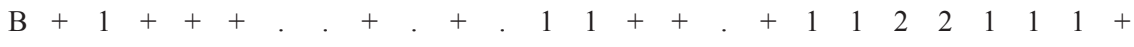

$\mathrm{C} .+21+++111++1+1++24426131$

$\mathrm{C}+1+++++1111++++++++++$ + +++ .

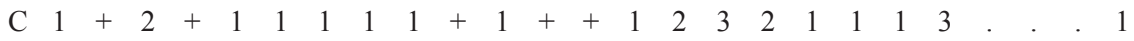

$\mathrm{C}+.+1++++$. $++1+++1 .+++++1$

$\mathrm{C} 1++2.2$. $+++++.+++++11+1+$. + .

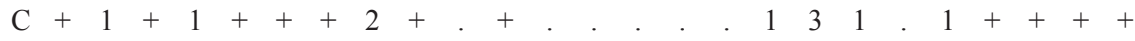

$\mathrm{C} .+.+.+2+1.2+2++2+2+2+$

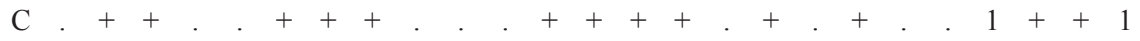

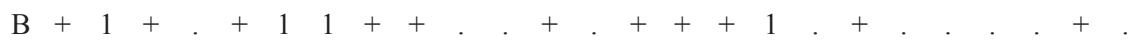

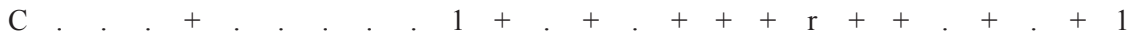

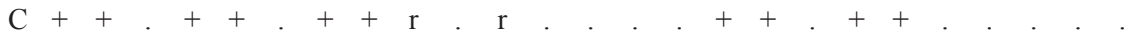

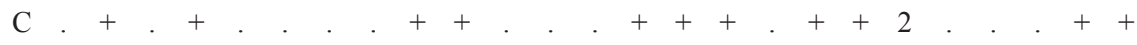

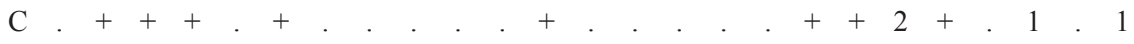

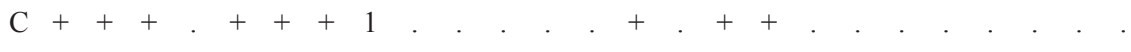

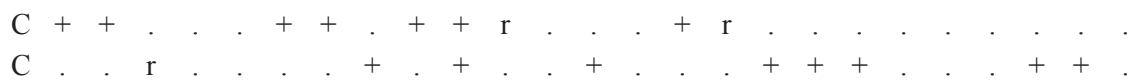


Salvia glutinosa

$\mathrm{C}$

Lathyrus vernus/vernus

$\mathrm{C}+1$

Chrysosplenium alternifolium $\mathrm{C}$

Polygonatum multiflorum

Lonicera alpigena

$\mathrm{C}+$

Polystichum aculeatum

Scrophularia nodosa

Mercurialis perennis

Epipactis helleborine

Galium laevigatum

Arum maculatum

Cerastium sylvaticum

Impatiens noli-tangere

Lathyrus vernus/flaccidus

Myosotis sylvatica

Phyllitis scolopendrium

Veronica montana

Lilium martagon

\section{QP Quercetalia pubescentis}

Sorbus aria

Fraxinus ornus

QF Querco-Fagetea

Anemone nemorosa

Carex digitata

Lonicera xylosteum

Corylus avellana

EP Erico-Pinetea

Rubus saxatilis

VP Vaccinio-Piceetea

Abies alba

Oxalis acetosella

Maianthemum bifolium

Luzula luzuloides

Lonicera nigra

Gentiana asclepiadea

Rosa pendulina

Gymnocarpium dryopteris

Dryopteris expansa

Hieracium murorum

Solidago virgaurea

Dryopteris dilatata

Veronica urticifolia

Homogyne sylvestris

Vaccinium myrtillus

MA Mulgedio-Aconitetea

Senecio ovatus

Athyrium filix-femina

Geranium robertianum

$\mathrm{B} 1+.2+2.2 .1 .2$

$\mathrm{C} . .++. . \quad$..++

$\mathrm{C} \cdot{ }^{\circ}+{ }^{\circ} \cdot{ }^{\circ} \mathrm{r} 1$

$\mathrm{C} \cdot \cdot+$

$\mathrm{C} \cdot \mathrm{r} \cdot+$

$\mathrm{C}+$

C

$\mathrm{C}$

C

$\mathrm{C}+$

C

$\mathrm{C}$

$\mathrm{C}$

C

$\mathrm{B}+$

C

B

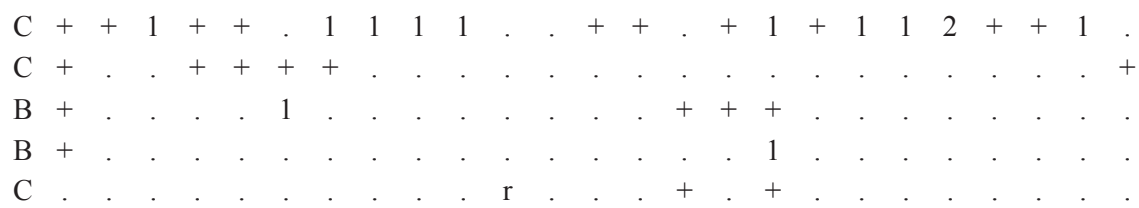

C

$\begin{array}{llllllllllllllllllllllllll}\mathrm{A} & 2 & 2 & 2 & 2 & 3 & 3 & 3 & 4 & 2 & 2 & 2 & 1 & 2 & 4 & 4 & 3 & 4 & 3 & 3 & 3 & 1 & 2 & 2 & 1 & 3\end{array}$

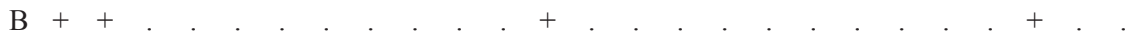

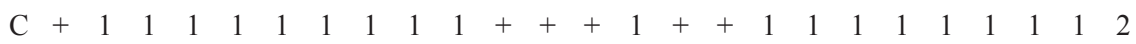

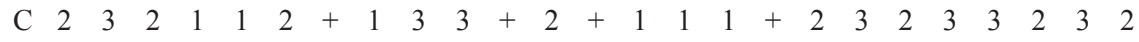

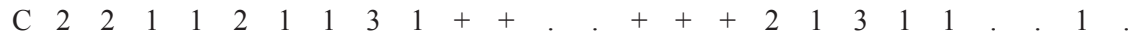

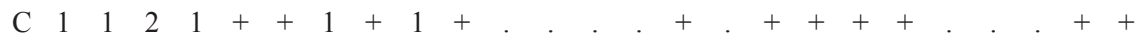

$\mathrm{B}++$. . $11+. .2 .+1+\mathrm{r}+.1 .+1$.

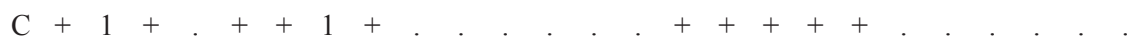

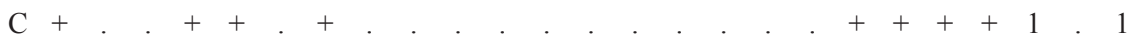

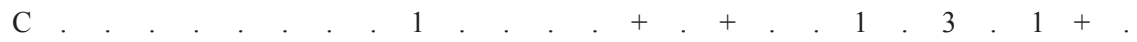

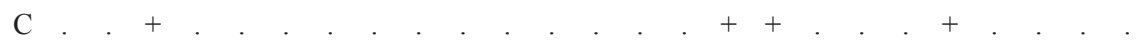

$\mathrm{C}$. . . . . +++ . . . . . . . +

$\mathrm{C}+$

$\mathrm{C}$

$\mathrm{C}$

$\mathrm{C}$

$\mathrm{C} \cdot \mathrm{r}$.

C $1+++121++1++1++11++11+\ldots++$

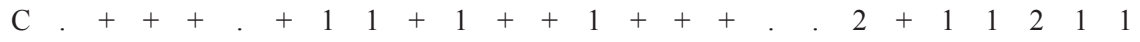

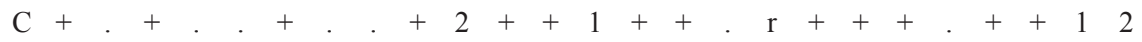


Urtica dioica

Polygonatum verticillatum

Veratrum album

Ranunculus platanifolius

AT Asplenietea trichomanis Asplenium trichomanes Polypodium vulgare Cystopteris fragilis Moehringia muscosa Asplenium viride Cymbalaria muralis

\section{TR Thlaspietea rotundifolii}

TR Adenostyles glabra

Other taxa

Rubus idaeus

Sorbus aucuparia

Galeopsis speciosa

Dactylorhiza maculata

Fragaria vesca

Solanum dulcamara

Sambucus racemosa

Polystichum x luerssenii

Lichens and mosses

Ctenidium molluscum

Neckera crispa

Grimmia pulvinata

Cladonia coniocraea

Cladonia pyxidata

Dicranum scoparium

Plagiomnium undulatum

Cladonia digitata

Plagiochila asplenioides Hypnum cupressiforme

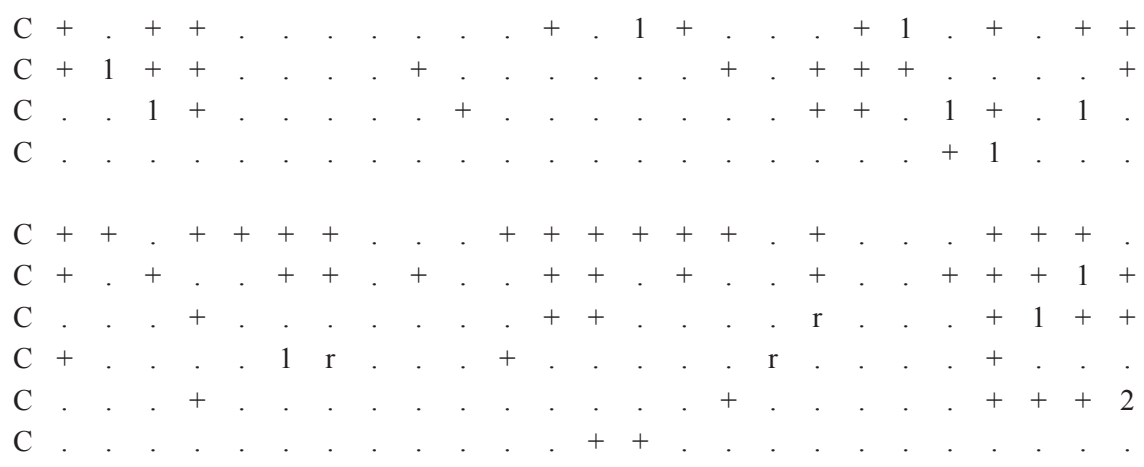

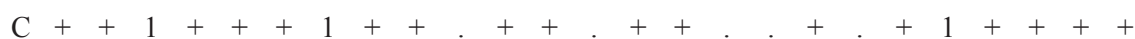

B $11++++++.1++2++++1+22+11+$

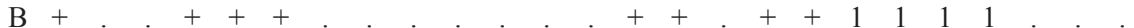
$\mathrm{C} .+++11+1+. .+.+1+2+1+.+$.

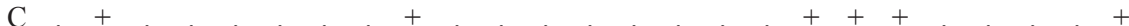

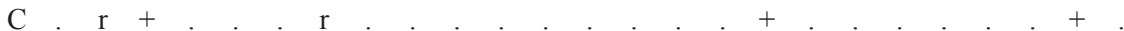
$\mathrm{C}++$

$\mathrm{C}$ $\mathrm{B}+$ C

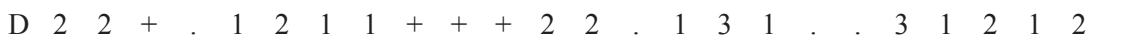
$\mathrm{D} 21+.1 .++.++21.11+.2 .22223$

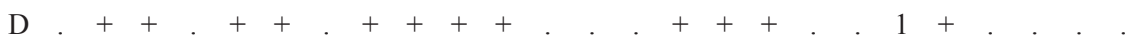

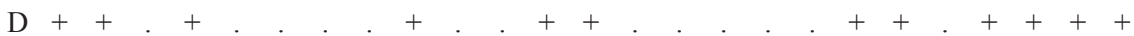
$\mathrm{D}++.+$. . . . . . . . . . . . . . + . + + .

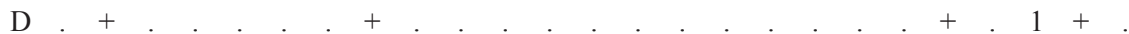
$\mathrm{D} . .+.+1 . .+.+1$ $\mathrm{D} . .+$. . . . . . . + . . . . . . . . ++ $\mathrm{D} .++$. . . . . . . 1 . . . . . . 1 . .

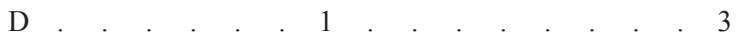


Table 9: Analytical table of the subassociation Omphalodo-Fagetum var. geogr. Saxifraga cuneifolia festucetosum altissimae (II) subass. nova in the Trnovski gozd plateau (NW Dinaric Alps; complete linkage, Euclidian distances).

Tabela 9: Analizna tabela subasociacije Omphalodo-Fagetum var. geogr. Saxifraga cuneifolia festucetosum altissimae (II) subass. nova v Trnovskem gozdu (severozahodni Dinaridi; metoda popolnega povezovanja, Evklidske razdalje).

\begin{tabular}{|c|c|c|c|c|c|c|c|c|c|c|c|c|c|c|c|c|c|c|c|c|c|c|c|c|c|c|c|c|c|}
\hline & Taxa & & 1 & 2 & 3 & 4 & 5 & 6 & 7 & 8 & 9 & 10 & 11 & 12 & 13 & 14 & 15 & 16 & 17 & 18 & 19 & 20 & 21 & 22 & 23 & 24 & 25 & 26 & 2 \\
\hline & \multicolumn{29}{|c|}{ Characteristic species of the association Omphalodo-Fagetum } \\
\hline $\mathrm{AF}$ & Cardamine trifolia & $\mathrm{C}$ & + & + & + & . & 1 & 1 & + & + & 1 & 1 & 1 & 2 & 1 & + & 1 & 1 & 1 & 1 & 1 & 2 & 1 & 1 & + & 2 & 1 & 1 & \\
\hline $\mathrm{AF}$ & Aremonia agrimon & $\mathrm{C}$ & + & + & + & . & 1 & 1 & + & + & + & + & + & + & + & + & + & + & + & + & . & + & + & . & . & + & + & . & + \\
\hline $\mathrm{AF}$ & Rhamnus fallax & B & 1 & $\cdot$ & + & 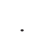 & $v^{\circ}$ & 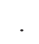 & $\cdot$ & 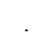 & 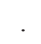 & . & . & . & . & . & ${ }^{\circ}$ & . & . & . & . & . & . & $\cdot$ & . & . & . & . & \\
\hline \multicolumn{30}{|c|}{ Differential species for the geographical variant Saxifraga cuneifolia } \\
\hline $\mathrm{VP}$ & Saxifraga cuneifolia & $\mathrm{C}$ & & . & . & . & . & . & . & $\cdot$ & . & + & . & + & + & 1 & 1 & + & + & . & . & . & . & . & . & . & + & + & \\
\hline \multicolumn{30}{|c|}{ Differential species for the subassociation -festucetosum altissimae } \\
\hline FS & Festuca altissima & & 2 & 4 & 3 & 1 & 3 & 3 & + & + & 2 & 1 & + & + & + & + & + & + & + & + & + & + & 1 & 1 & + & + & + & + & \\
\hline \multicolumn{30}{|c|}{ AF Aremonio-Fagion } \\
\hline & Cardamine & & + & . & r & . & + & + & . & . & 1 & + & 1 & + & . & + & + & . & + & . & 1 & 1 & 1 & 1 & + & . & + & . & \\
\hline & Lamiun & $\mathrm{C}$ & & . & + & . & . & $\mathrm{r}$ & . & . & . & . & . & . & . & . & . & . & . & 1 & 1 & . & . & . & . & . & . & . & \\
\hline & Vicia oroboides & 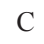 & & + & . & + & . & . & . & . & . & + & . & . & . & . & . & . & . & . & . & . & . & . & . & . & . & . & \\
\hline
\end{tabular}

FS Fagetalia sylvaticae

Fagus sylvatica

Dryopteris filix-mas

$\begin{array}{llllllllllllllllllllllllllll}\text { A } 2 & 2 & 1 & + & 2 & 2 & 3 & 4 & 3 & 3 & 2 & 3 & 3 & 3 & 1 & 1 & 2 & 2 & 3 & 3 & 1 & 3 & 3 & 1 & 2 & 3 & 2\end{array}$

Galeobdolon flavidum

$\mathrm{B} .+1+23++++$ + $++++1+++++++++1$

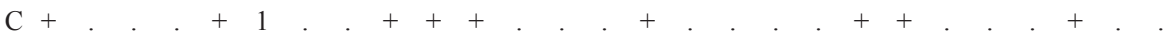

Mycelis muralis

Prenanthes purpurea

Acer pseudoplatanus

Daphne mezereum

Paris quadrifolia

Actaea spicata

Carex sylvatica

Epilobium montanum

Galium odoratum

Lonicera alpigena

Polystichum aculeatum

Sanicula europaea

Epipactis helleborine

Sambucus nigra

Viola reichenbachiana

Stellaria montana

Milium effusum

$\mathrm{C}++++1+++++++++++1++++++++$

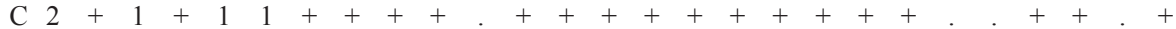

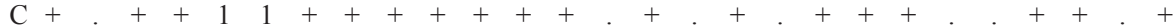

Salvia glutinosa

Galium laevigatum

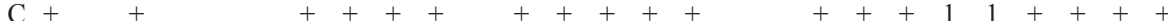

Mercurialis perennis

Neottia nidus-avis

Scrophularia nodosa

Cardamine bulbifera

Lilium martagon

Phyllitis scolopendrium

Polygonatum multiflorum

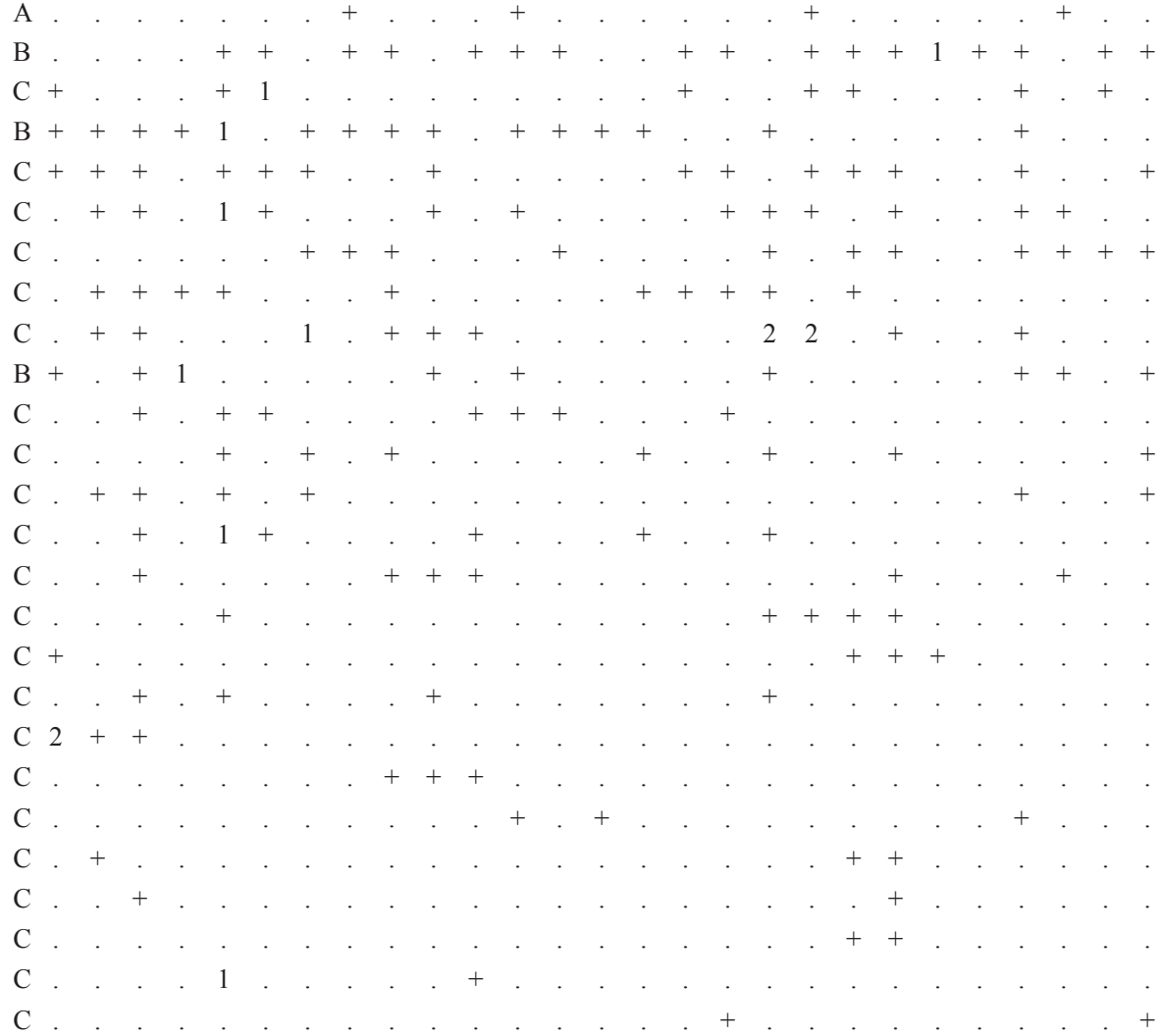


QP Quercetalia pubescentis

Sorbus aria

Sesleria autumnalis

QF Querco-Fagetea

Anemone nemorosa

Carex digitata

Lonicera xylosteum

VP Vaccinio-Piceetea

Abies alba

Oxalis acetosella

Gentiana asclepiadea

Lonicera nigra

Calamagrostis arundinacea

Luzula luzuloides

Dryopteris dilatata

Rosa pendulina

Solidago virgaurea

Maianthemum bifolium

Picea abies

Vaccinium myrtillus

Orthilia secunda

Luzula luzulina

Rubus hirtus

Homogyne sylvestris

Huperzia selago

Phegopteris connectilis

Gymnocarpium dryopteris

Luzula sylvatica/sylvatica

Thelypteris limbosperma

Veronica urticifolia

MA Mulgedio-Aconitetea

Athyrium filix-femina

Senecio ovatus

Geranium robertianum

Polygonatum verticillatum

Veratrum album

AT Asplenietea trichomanis

Asplenium trichomanes

Asplenium viride

Moehringia muscosa

Polypodium vulgare

Asplenium ruta-muraria

TR Thlaspietea rotundifolii

Adenostyles glabra

Other taxa

Sorbus aucuparia
B.

C 2

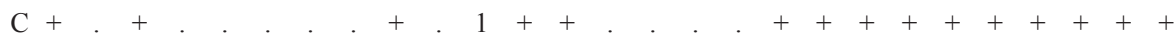

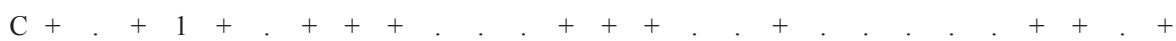

$\mathrm{B}+$

$\begin{array}{llllllllllllllllllllllllllll}\mathrm{A} & 3 & 2 & 4 & 4 & 3 & 3 & 3 & 1 & 2 & 2 & 4 & 3 & 2 & 3 & 4 & 3 & 4 & 4 & 3 & 3 & 3 & 3 & 1 & 4 & 3 & 3 & 2\end{array}$

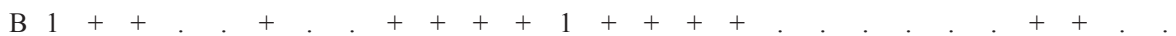

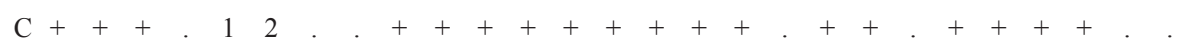

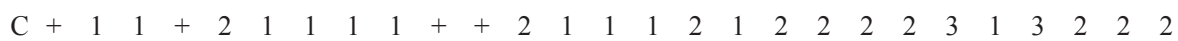

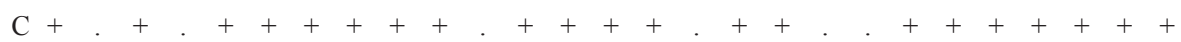

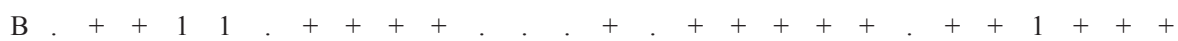

$\mathrm{C} .++\begin{aligned} & + \\ & \mathrm{C}\end{aligned}$

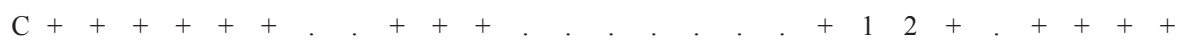

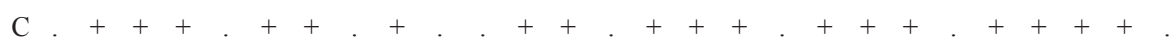

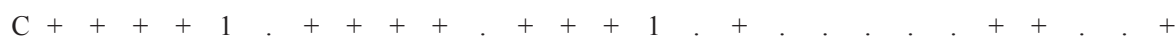

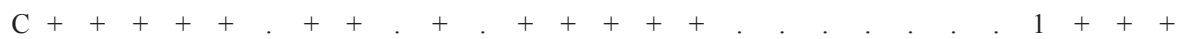

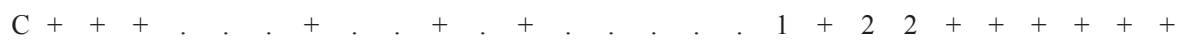

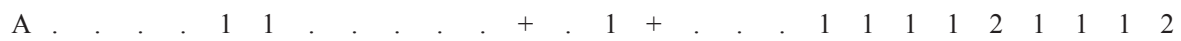

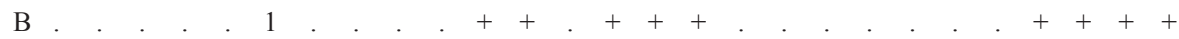

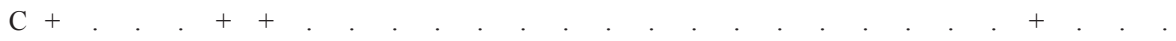

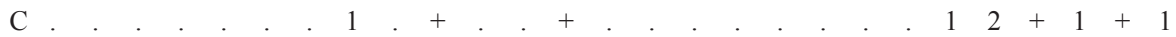
C. ++1 . . . . . . + . . . . . . . . . . . + . + . C. . . . . . . . . . . . . . . . . . . +1 . . . +++ $\mathrm{B}$ C C C C C C C

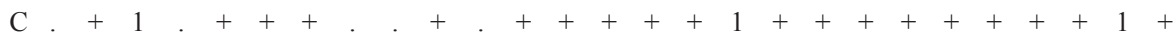
$\mathrm{C} 1++.+2+.+2 .+2 .++++1 .++++$. + . + .

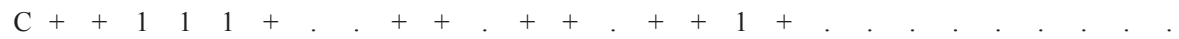

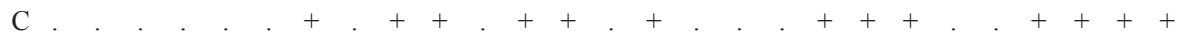
$\mathrm{C}$

$\mathrm{C}++1+12$ $\mathrm{C} \cdot+. \quad 1+$ $\mathrm{C}++++1$ $\mathrm{C} \cdot+\cdot+1+$ C

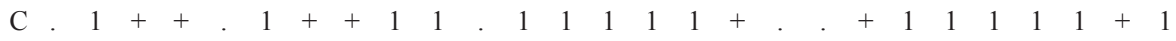

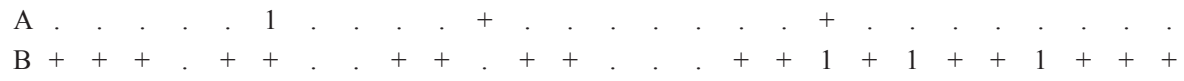
C 
Rubus idaeus

Solanum dulcamara

Fragaria vesca

\section{Lichens and mosses}

Ctenidium molluscum

Neckera crispa

Polytrichum formosum

Isothecium alopecuroides

Dicranum scoparium

Plagiochila asplenioides

Fissidens dubius

Cladonia pyxidata

Peltigera aphthosa

Eurhynchium zetterstedtii

Atrichum undulatum

Plagiothecium sp.

Tortella tortuosa

Grimmia pulvinata

Hylocomium splendens

Hypnum cupressiforme

Plagiomnium undulatum

Anomodon viticulosus

Mnium orthorrhynchium

Neckera complanata

Rhytidiadelphus triquetrus

Camptothecium lutescens

Metzgeria conjugata

Plagiothecium sylvaticum

Rhizomnium punctatum

Rhytidiadelphus loreus

Cladonia rangiferina

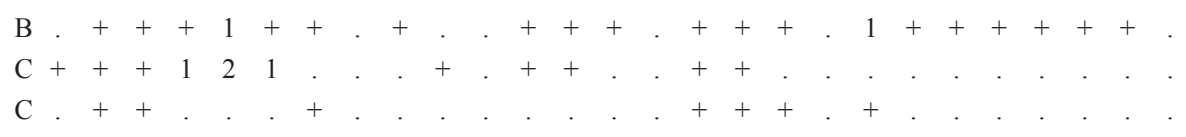

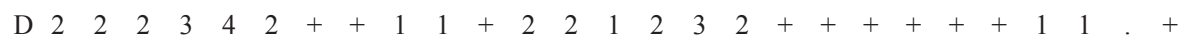

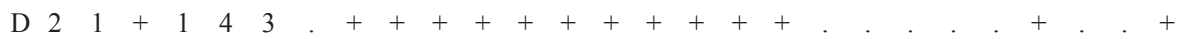

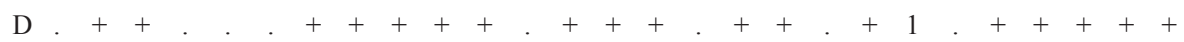

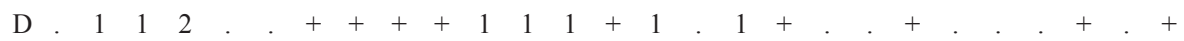

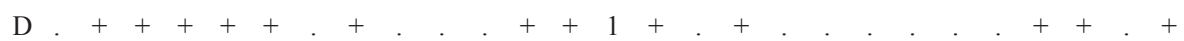

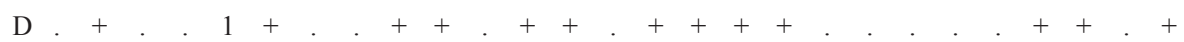

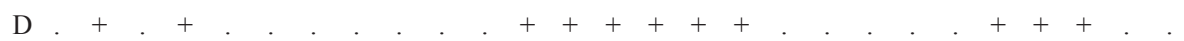

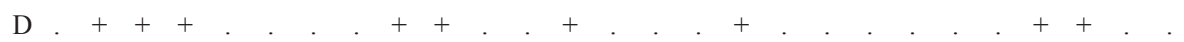

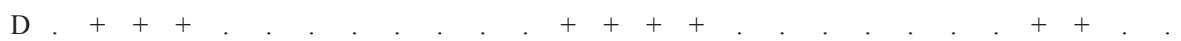

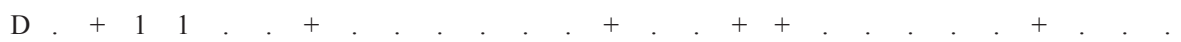

$\mathrm{D}$. . . . . . . . . . . . . . . . . . . . . . . . + . +++

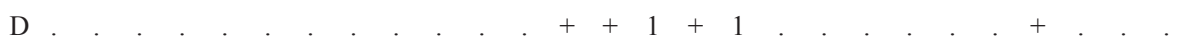

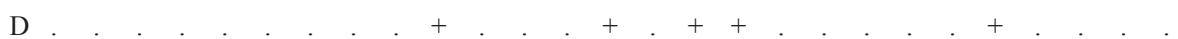

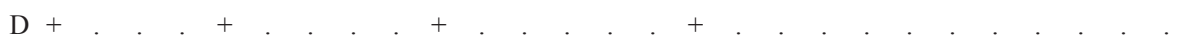

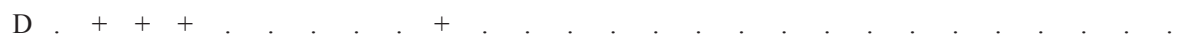

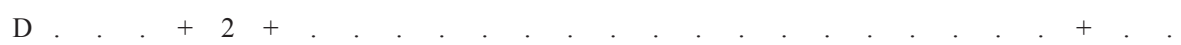

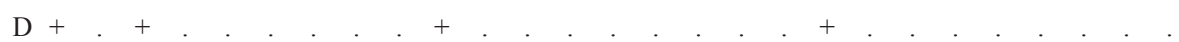

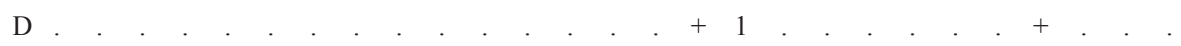

$\mathrm{D}$. . . . . . . . . . . . . . . . . . . ...++

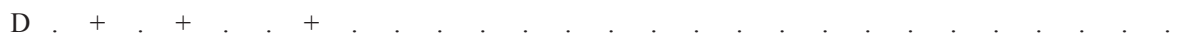

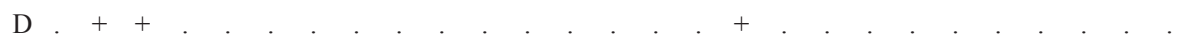

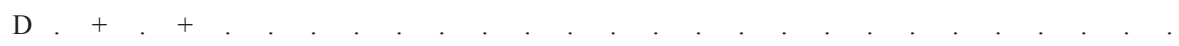

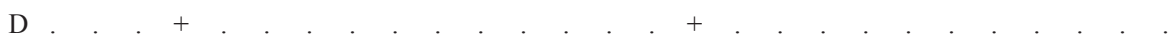

$\mathrm{D}$.

$\mathrm{D}$.

D

D 
Table 10: Analytical table of the subassociation Omphalodo-Fagetum var. geogr. Saxifraga cuneifolia stellarietosum montanae subass. nova in the Trnovski gozd plateau (NW Dinaric Alps; complete linkage, Euclidian distances).

Tabela 10: Analizna tabela subasociacije Omphalodo-Fagetum var. geogr. Saxifraga cuneifolia stellarietosum montanae subass. nova v Trnovskem gozdu (severozahodni Dinaridi; metoda popolnega povezovanja, Evklidske razdalje).

\begin{tabular}{|c|c|c|c|c|c|c|c|c|c|c|c|c|c|c|c|c|c|c|c|c|c|c|}
\hline Taxa & & 1 & 2 & 3 & 4 & 5 & 6 & $7 *$ & 8 & 9 & 10 & 11 & 12 & 13 & 14 & 15 & $16 *$ & 17 & 18 & 19 & 20 & 21 \\
\hline \multicolumn{23}{|c|}{ Characteristic species of the association Omphalodo-Fagetum } \\
\hline Cardamine trifolia & $\mathrm{C}$ & . & . & 1 & + & 1 & + & 1 & 1 & $\cdot$ & . & . & + & + & + & + & + & + & . & . & . & \\
\hline Aremonia agrimonoides & $\mathrm{C}$ & . & + & + & + & . & 1 & + & + & . & + & + & + & . & . & . & $\mathrm{r}$ & . & . & . & 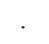 & ${ }^{\circ}$ \\
\hline Omphalodes verna & $\mathrm{C}$ & . & 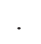 & . & $\cdot$ & . & . & 2 & . & . & . & $\cdot$ & . & $\cdot$ & . & + & . & . & + & $\cdot$ & . & 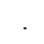 \\
\hline Rhamnus fallax & $\mathrm{B}$ & . & $\cdot$ & $\cdot$ & . & $\cdot$ & . & . & . & . & . & + & . & . & . & . & . & . & . & . & . & + \\
\hline \multicolumn{23}{|c|}{ Differential species for the geographical variant Saxifraga cuneifolia } \\
\hline Saxifraga cuneifolia & $\mathrm{C}$ & . & $\cdot$ & . & $\cdot$ & $\cdot$ & . & + & . & . & . & . & . & . & . & . & $\mathrm{r}$ & . & . & + & . & . \\
\hline \multicolumn{23}{|c|}{ Differential species for the subassociation -stellarietosum montanae } \\
\hline Stellaria montana & $\mathrm{C}$ & 2 & 3 & 1 & 1 & 2 & 2 & 2 & 1 & 1 & 2 & 2 & 2 & 2 & . & . & 1 & 1 & + & + & 1 & + \\
\hline Impatiens noli-tangere & $\mathrm{C}$ & 1 & + & 2 & $\cdot$ & 4 & 3 & + & 2 & + & 1 & 2 & 2 & 2 & . & + & + & + & + & + & . & . \\
\hline Adoxa moschatellina & $\mathrm{C}$ & . & ${ }^{\circ}$ & . & 1 & 1 & + & + & + & + & + & . & + & + & + & . & + & 1 & + & 1 & 1 & 1 \\
\hline Arum maculatum & $\mathrm{C}$ & + & + & + & + & 1 & 1 & $\cdot$ & . & + & + & . & . & . & + & . & + & + & + & + & + & . \\
\hline Lunaria rediviva & $\mathrm{C}$ & + & 1 & 4 & 4 & $\cdot$ & . & + & . & 5 & + & . & . & . & + & . & 1 & + & 1 & . & 3 & \\
\hline Circaea lutetiana & $\mathrm{C}$ & + & + & . & + & $\mathrm{r}$ & + & . & . & . & + & 1 & 1 & . & . & . & + & . & $\mathrm{r}$ & + & . & \\
\hline
\end{tabular}

\section{Differential species for the variant}

FS Cardamine pentaphyllos Mercurialis perennis

AF Aremonio-Fagion

Lamium orvala

Cardamine enneaphyllos

Anemone trifolia

Polystichum setiferum

Scopolia carniolica

Calamintha grandiflora

FS Fagetalia sylvaticae

Fagus sylvatica

Paris quadrifolia

Dryopteris filix-mas

Cardamine bulbifera

Festuca altissima

Mycelis muralis

Acer pseudoplatanus

Actaea spicata

Sambucus nigra

Salvia glutinosa

Galium odoratum

Galeobdolon flavidum

Daphne mezereum

Myosotis sylvatica

Epilobium montanum

Phyllitis scolopendrium

Chrysosplenium alternifolium
C

\begin{tabular}{|llllllll|}
\hline 1 & 2 & 2 & 2 & 2 & 3 & 2 &. \\
. & 1 & + & 1 & 1 & 1 & 1 & 2 \\
\hline
\end{tabular}

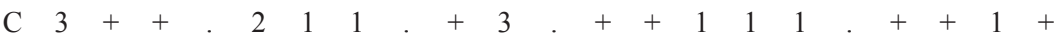

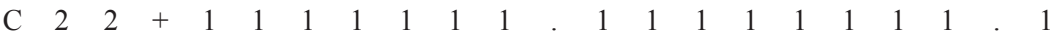

$\mathrm{C}$

$\mathrm{C}$

$\mathrm{C}$

$\mathrm{C}$

$\begin{array}{llllllllllllllllllllll}\mathrm{A} & 3 & 4 & 4 & 2 & 2 & 3 & 3 & + & 5 & 4 & 2 & 2 & 2 & 4 & 4 & 4 & 5 & 5 & 4 & 3 & 5\end{array}$

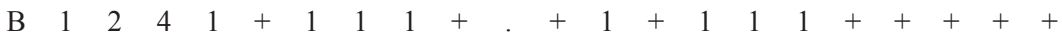

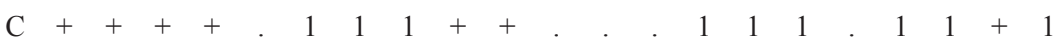

$\mathrm{C}+++++1+1++++++++1+++1$

$\begin{array}{llllllllllllllllllllll}\mathrm{C} & 2 & 3 & 1 & 2 & 2 & 2 & 1 & 1 & 1 & 1 & 2 & 2 & 1 & 1 & 1 & 1 & 1 & 1 & 1 & 1 & +\end{array}$

$\begin{array}{llllllllllllllllllllll}\mathrm{C} & 1 & 1 & 1 & 1 & 1 & + & 1 & 1 & 1 & 1 & + & + & 1 & 1 & 1 & + & + & + & 1 & 1\end{array}$

$\mathrm{C}+++1+3 .++1++++212++$. +

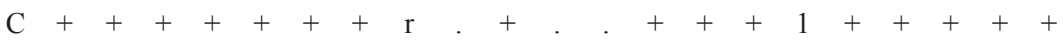

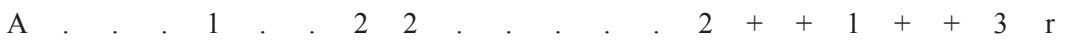

$\begin{array}{llllllllllllllllll}\mathrm{B} & 3 & 1 & 5 & 3 & 2 & 2 & 1 & 2 & + & 1 & 1 & 1 & + & 1 & + & + & 1\end{array}$.

$\mathrm{C}+. \begin{array}{llllllllllllllllllll} & & 2 & 1 & 1 & 3 & 2 & 2 & . & 1 & . & . & . & 1 & 1 & 1 & 1 & 1 & 1 & 1\end{array}$

$\mathrm{C}+++$. +++++ . + . $+1++++$

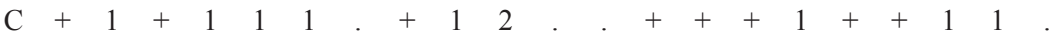

$\mathrm{C}+.++++$. + . +1 . ++++++

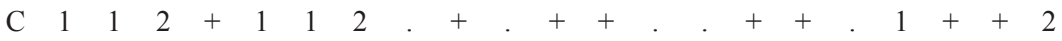

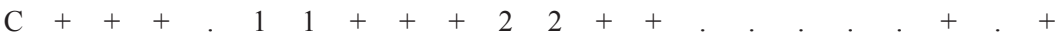

$\mathrm{B}+++++1+.+\mathrm{r}+++. .6 .+$.

$\mathrm{C}+.+++.+1 .+1 .+1 .+1 .+$

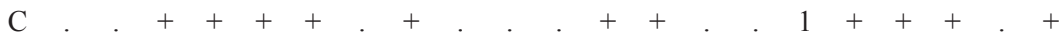

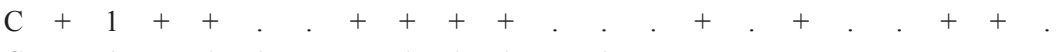


Polystichum aculeatum

Cardamine impatiens

Scrophularia nodosa

Milium effusum

Lonicera alpigena

Lathyrus vernus/vernus

Polygonatum multiflorum

Prenanthes purpurea

Sanicula europaea

Symphytum tuberosum

Carex sylvatica

Corydalis solida

Ranunculus lanuginosus

Viola reichenbachiana

Galium laevigatum

Polystichum braunii

Corydalis cava

Acer platanoides

Campanula trachelium

Tilia platyphyllos

Ulmus glabra

Fraxinus excelsior

QP Quercetalia pubescentis

Arabis turrita

Hypericum montanum

Piptatherum virescens

QF Querco-Fagetea

Anemone nemorosa

Lonicera xylosteum

Platanthera bifolia

Moehringia trinervia

Vinca minor

Anemone x pittonii

Carex digitata

Corylus avellana

Gagea lutea

VP Vaccinio-Piceetea

Abies alba

Oxalis acetosella

Dryopteris dilatata

Maianthemum bifolium

Luzula luzuloides

Dryopteris expansa

Lonicera nigra

Phegopteris connectilis

Calamagrostis arundinacea

Gentiana asclepiadea

Veronica urticifolia

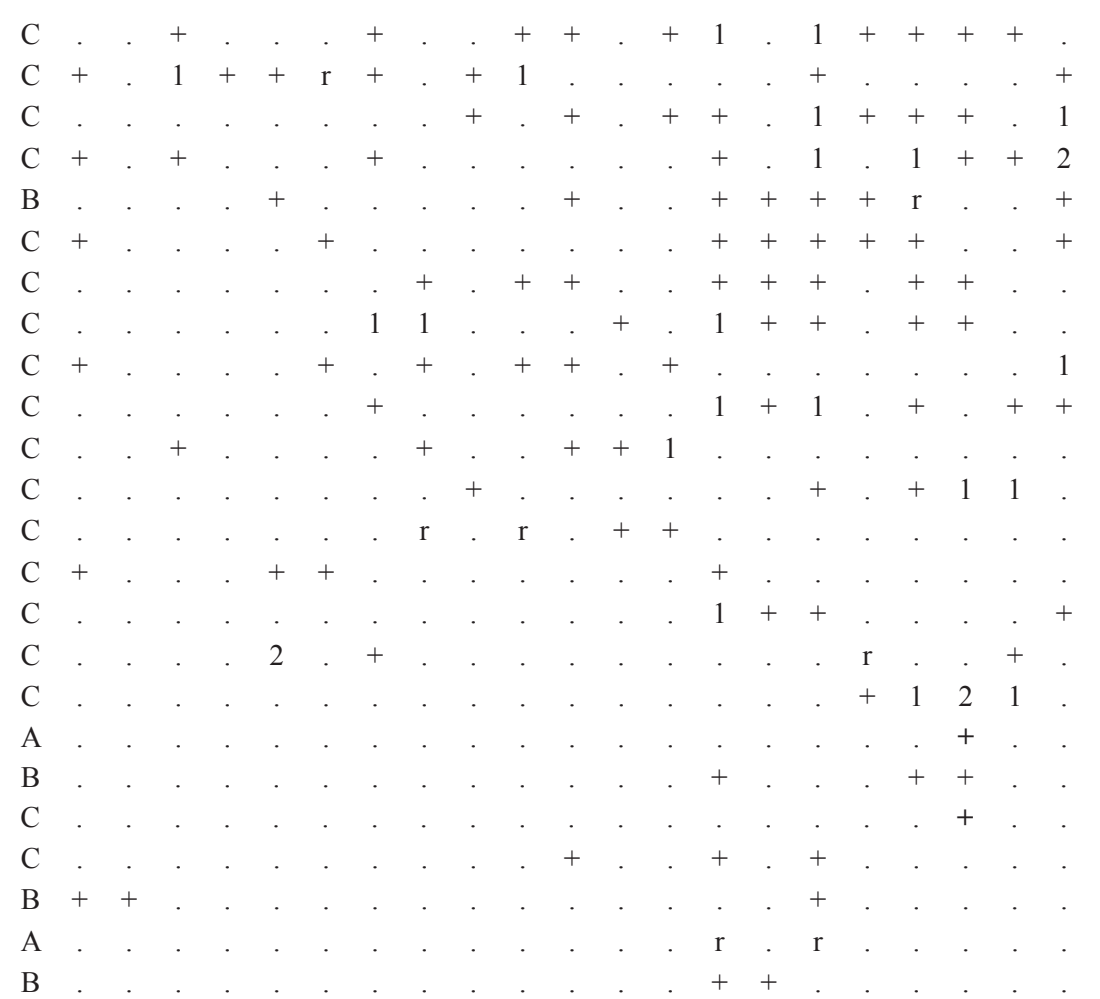

C

C

$\mathrm{C}$

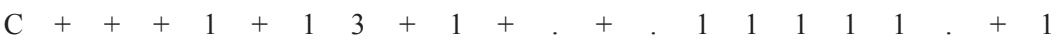

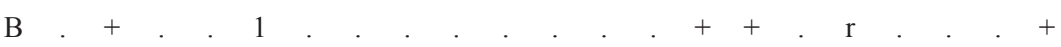

C

$\mathrm{C}$

$\mathrm{C}$

$\mathrm{C}$

$\mathrm{C}$

B

C

$\begin{array}{llllllllllllllllllllll}\mathrm{A} & 2 & 2 & 2 & 1 & 1 & 1 & 2 & 2 & 1 & 1 & 2 & 2 & 2 & + & 2 & 2 & 1 & 1 & 1 & 1 & 1\end{array}$

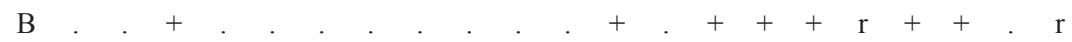

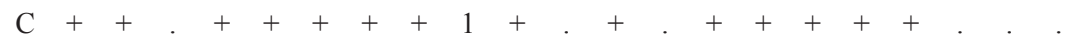
$\begin{array}{llllllllllllllllllllll}\mathrm{C} & 2 & 2 & 3 & + & 1 & 2 & 3 & 3 & 2 & 1 & 1 & 1 & 1 & . & 1 & 1 & . & 1 & + & +\end{array}$

$\mathrm{C}+$. . . . . . $+++\mathrm{r} \cdot++{ }^{+}++\mathrm{r}$

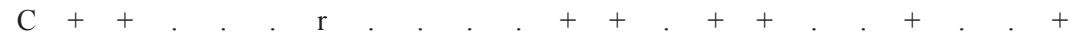

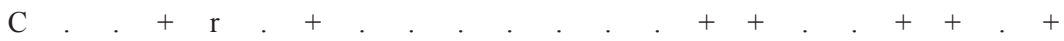

C

B

C

$\mathrm{C}$

$\mathrm{C}+$

C 
Gymnocarpium dryopteris

\section{C}

Picea abies

Polystichum lonchitis

MA Mulgedio-Aconitetea

Athyrium filix-femina

Senecio ovatus

Urtica dioica

Geranium robertianum

Polygonatum verticillatum

Veratrum album

Heracleum sphondylium

Aconitum lycoctonum

Saxifraga rotundifolia

AT Asplenietea trichomanis

Asplenium trichomanes

Cystopteris fragilis

Polypodium vulgare

Sedum hispanicum

Moehringia muscosa

TR Thlaspietea rotundifolii

Adenostyles glabra

\section{Other taxa}

Rubus idaeus

Solanum dulcamara

Sorbus aucuparia

Fragaria vesca

Polystichum x luerssenii

Atropa bella-donna

Galeopsis speciosa

Sambucus racemosa

\section{A}

C

$\mathrm{C}$

$\mathrm{C}+\begin{array}{lllllllllllllllll}2 & 1 & 2 & 2 & 1 & 2 & 5 & 1 & 1 & 2 & 2 & 2 & + & + & 1 & 1 & +\end{array}$

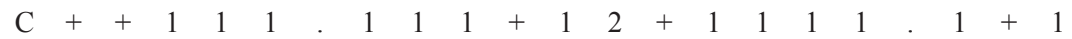

$\mathrm{C}+21+22+11+1+2 .+1+1+1$

$\mathrm{C}+.+++1.1+2 .+1 .+1 .+1$

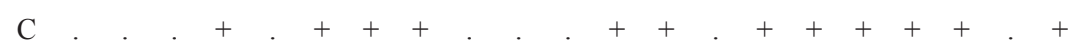

$\mathrm{C}$

C

$\mathrm{C}$

C

$\mathrm{C}++++++\ldots$

$\mathrm{C}$

C

C

C

C

1

Lichens and mosses

Ctenidium molluscum

Neckera crispa

Isothecium alopecuroides

Plagiomnium undulatum

Camptothecium lutescens

Plagiochila porelloides

Schistidium apocarpum

Bryum capillare

Hypnum cupressiforme

Mnium sp.

Conocephalum conicum

Homalothecium philippeanum

Hylocomium splendens

Plagiochila asplenioides

Thamnobryum alopecurum

Cladonia coniocraea

Grimmia pulvinata

Plagiomnium affine

$\mathrm{B}+2+1.211 .2 .1+2 . \quad 1 .+1$

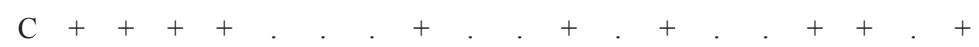

A

B

C

C

C

$\mathrm{C}$

$\mathrm{C}$

$\mathrm{B}$

$\mathrm{D}$

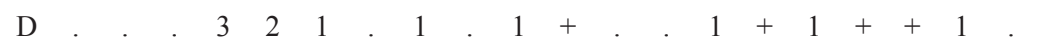

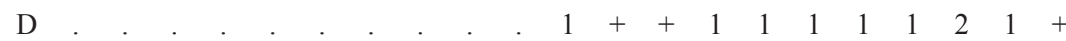

D . . $3 . .+. .21++. .2+++$

$\mathrm{D}$

$\mathrm{D}$

$\mathrm{D}$

$\mathrm{D}$

$\mathrm{D}$

$\mathrm{D}$

$\mathrm{D}$

$\mathrm{D}$

D

$\mathrm{D}$

D

D

D

D 
Anomodon viticulosus

Atrichum undulatum

Eurhynchium striatum

Mnium thomsonii

Polytrichum formosum

Porella platyphylla

Tortella tortuosa

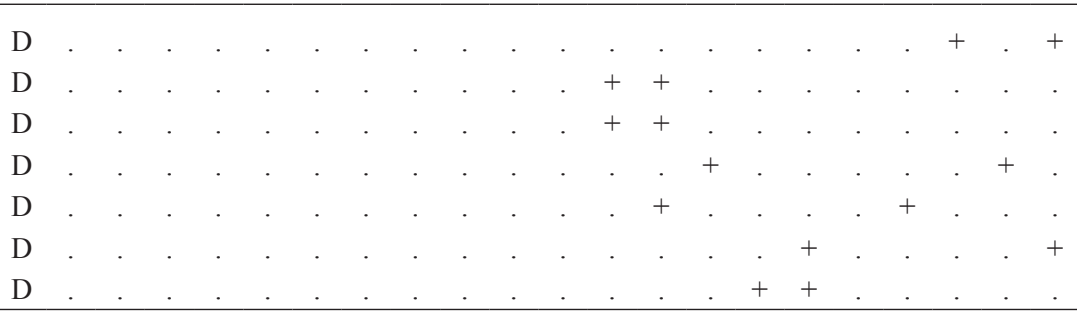

Table 11:Analytical table of the subassociation Omphalodo-Fagetum var. geogr. Saxifraga cuneifolia calamagrostietosum variae subass. nova in the Trnovski gozd plateau (NW Dinaric Alps; complete linkage, Euclidian distances).

Tabela 11: Analizna tabela subasociacije Omphalodo-Fagetum var. geogr. Saxifraga cuneifolia calamagrostietosum variae subass. nova v Trnovskem gozdu (severozahodni Dinaridi; metoda popolnega povezovanja, Evklidske razdalje).

\begin{tabular}{|c|c|c|c|c|c|c|c|c|c|c|c|c|c|c|c|c|c|c|c|}
\hline & Taxa & & 1 & 2 & 3 & $4 *$ & 5 & 6 & 7 & 8 & 9 & 10 & 11 & 12 & 13 & 14 & 15 & 16 & 17 \\
\hline \multicolumn{20}{|c|}{ Characteristic species of the association Omphalodo-Fagetum } \\
\hline $\mathrm{AF}$ & Omphalodes verna & $\mathrm{C}$ & + & + & . & . & . & . & . & . & + & + & + & + & 1 & + & 1 & + & . \\
\hline $\mathrm{AF}$ & Rhamnus fallax & $\mathrm{B}$ & . & + & + & + & + & . & . & + & + & + & . & . & + & + & . & + & . \\
\hline $\mathrm{AF}$ & Cardamine trifolia & $\mathrm{C}$ & . & . & + & . & . & . & . & + & + & + & . & . & . & . & + & + & . \\
\hline $\mathrm{AF}$ & Calamintha grandiflora & $\mathrm{C}$ & + & . & . & . & . & . & . & . & . & . & . & . & . & . & . & . & . \\
\hline \multicolumn{20}{|c|}{ Differential species for the geographical variant Saxifraga cuneifolia } \\
\hline \multirow[t]{2}{*}{ AT } & Paederota lutea & $\mathrm{C}$ & + & + & + & + & + & + & + & . & $\mathrm{r}$ & $\mathrm{r}$ & + & + & 1 & + & 1 & + & + \\
\hline & & A & . & . & . & $\mathrm{r}$ & + & . & . & + & . & . & . & + & + & . & . & . & + \\
\hline \multirow[t]{2}{*}{ FS } & Laburnum alpinum & $\mathrm{B}$ & + & + & + & $\mathrm{r}$ & + & . & . & . & + & + & . & . & + & . & + & 1 & . \\
\hline & & $\mathrm{C}$ & + & + & + & 1 & 1 & 1 & . & + & + & + & + & + & + & + & + & + & + \\
\hline AT & Phyteuma scheuchzeri/columnae & $\mathrm{C}$ & . & . & + & + & + & . & 1 & . & . & + & . & . & . & . & . & + & 1 \\
\hline \multicolumn{20}{|c|}{ Differential species for the subassociation -calamagrostietosum variae } \\
\hline $\mathrm{EP}$ & Calamagrostis varia & $\mathrm{C}$ & + & 1 & 1 & 1 & + & 1 & 1 & + & 1 & 1 & + & 1 & + & + & 2 & 1 & 1 \\
\hline EP & Carex alba & $\mathrm{C}$ & + & + & + & 3 & + & . & + & . & + & 1 & . & . & 2 & + & + & 1 & . \\
\hline FS & Polygonatum multiflorum & $\mathrm{C}$ & + & . & . & + & + & . & . & + & + & + & . & + & + & + & 1 & + & . \\
\hline $\mathrm{AF}$ & Rhamnus fallax & $\mathrm{B}$ & . & + & + & + & + & . & . & + & + & + & . & . & + & + & . & + & . \\
\hline $\mathrm{AF}$ & Helleborus niger & $\mathrm{C}$ & . & 1 & 1 & 1 & 1 & + & 1 & . & . & + & 1 & . & . & . & 1 & . & . \\
\hline EP & Buphthalmum salicifolium & $\mathrm{C}$ & . & . & . & + & + & . & . & . & + & + & . & . & + & + & . & + & . \\
\hline \multicolumn{20}{|c|}{ AF Aremonio-Fagion } \\
\hline & Cyclamen purpurascens & $\mathrm{C}$ & 1 & 1 & 1 & 1 & + & + & 1 & 1 & + & + & . & + & + & 1 & + & 1 & . \\
\hline & Cardamine enneaphyllos & $\mathrm{C}$ & 2 & 1 & 1 & . & + & . & + & 2 & 1 & 1 & 1 & 1 & 1 & 1 & 1 & 1 & 1 \\
\hline & Euphorbia carniolica & $\mathrm{C}$ & + & + & . & . & . & . & . & + & + & + & + & . & . & . & + & . & . \\
\hline & Scopolia carniolica & $\mathrm{C}$ & + & . & . & . & . & . & . & 1 & + & . & . & . & . & . & 1 & 1 & . \\
\hline & Lamium orvala & $\mathrm{C}$ & 1 & . & . & . & . & . & . & + & . & + & 1 & . & . & . & . & . & . \\
\hline & Knautia drymeia & $\mathrm{C}$ & . & . & . & . & + & . & . & . & . & . & . & + & + & . & . & . & . \\
\hline & Hacquetia epipactis & $\mathrm{C}$ & . & . & . & . & . & . & . & . & . & 1 & 1 & . & . & . & . & . & . \\
\hline \multirow[t]{10}{*}{ FS } & Fagetalia sylvaticae & & & & & & & & & & & & & & & & & & \\
\hline & & $\mathrm{A}$ & 5 & 4 & 4 & 5 & 5 & 5 & 4 & 4 & 4 & 5 & 5 & 4 & 4 & 4 & 4 & 4 & 4 \\
\hline & Fagus sylvatica & $\mathrm{B}$ & 1 & 1 & 1 & + & 1 & 1 & 1 & 2 & 2 & 3 & 2 & 2 & 1 & + & 1 & 1 & 1 \\
\hline & & $\mathrm{C}$ & . & 1 & + & + & + & 1 & + & + & 1 & 1 & 1 & 1 & 1 & + & 1 & 1 & 1 \\
\hline & & $\mathrm{A}$ & + & + & 1 & + & $\mathrm{r}$ & 1 & + & + & 1 & + & 1 & + & + & 1 & 1 & 1 & + \\
\hline & Acer pseudoplatanus & $\mathrm{B}$ & + & + & + & . & . & . & . & . & . & . & . & . & . & . & . & + & . \\
\hline & & $\mathrm{C}$ & + & 1 & . & + & + & + & + & + & 1 & 1 & + & 1 & 1 & 1 & + & + & + \\
\hline & Prenanthes purpurea & $\mathrm{C}$ & + & 1 & + & + & 1 & 1 & 1 & 1 & 1 & 1 & 1 & 1 & 1 & + & + & 1 & 1 \\
\hline & Mercurialis perennis & $\mathrm{C}$ & 1 & 1 & 1 & 1 & 1 & 1 & . & 1 & 1 & 1 & 1 & 1 & 1 & 1 & 1 & 1 & 1 \\
\hline & Daphne mezereum & $\mathrm{B}$ & + & + & 1 & 1 & + & + & . & + & 1 & 1 & 1 & 1 & . & 1 & + & + & + \\
\hline
\end{tabular}




Taxa
Galium laevigatum
Dryopteris filix-mas
Epipactis helleborine
Phyteuma spicatum/coeruleum
Salvia glutinosa
Galeobdolon flavidum
Lonicera alpigena
Mycelis muralis
Neottia nidus-avis
Fraxinus excelsior
Polystichum aculeatum
Actaea spicata
Lilium martagon
Aruncus dioicus
Euphorbia amygdaloides
Melica nutans
Lathyrus vernus/vernus
Paris quadrifolia
Symphytum tuberosum
Asarum europaeum/caucasicum
Cephalanthera longifolia
Cardamine bulbifera
Sambucus nigra
Scrophularia nodosa
Ulmus glabra
Quercetalia pubescentis

Sorbus aria

Fraxinus ornus

Melittis melissophyllum

Ostrya carpinifolia

\begin{tabular}{lllllllllllllllll}
1 & 2 & 3 & $4 *$ & 5 & 6 & 7 & 8 & 9 & 10 & 11 & 12 & 13 & 14 & 15 & 16 & 17 \\
\hline
\end{tabular}

\begin{tabular}{|c|c|c|c|c|c|c|c|c|c|c|c|c|c|c|c|c|c|}
\hline $\mathrm{C}$ & $\cdot$ & & 1 & 1 & 1 & 1 & 1 & 1 & 1 & + & 1 & 1 & 1 & + & 1 & 1 & 1 \\
\hline $\mathrm{C}$ & 1 & + & + & + & . & + & + & + & + & + & + & $\mathrm{r}$ & . & + & + & . & + \\
\hline $\mathrm{C}$ & . & . & + & + & + & + & + & . & + & + & + & + & + & + & 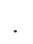 & + & + \\
\hline $\mathrm{C}$ & . & $\mathrm{r}$ & + & + & . & + & 1 & + & + & 1 & 1 & 1 & 1 & . & + & . & + \\
\hline $\mathrm{C}$ & + & + & + & 1 & + & . & . & + & 1 & 1 & 1 & + & . & 1 & + & + & . \\
\hline $\mathrm{C}$ & + & 1 & + & . & + & + & . & 1 & 1 & 1 & 1 & + & . & 1 & . & . & + \\
\hline B & + & 1 & . & . & + & . & . & 1 & + & + & + & + & 1 & . & 1 & . & + \\
\hline $\mathrm{C}$ & + & + & . & 1 & + & + & 1 & + & + & + & 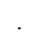 & . & . & + & . & + & . \\
\hline $\mathrm{C}$ & 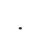 & . & . & + & + & + & . & . & . & + & + & + & + & + & . & + & + \\
\hline A & + & + & + & . & . & . & . & $\mathrm{r}$ & . & $\mathrm{r}$ & $\mathrm{r}$ & . & . & 1 & . & . & . \\
\hline B & . & + & 1 & . & . & . & . & + & + & . & . & + & . & + & . & . & . \\
\hline $\mathrm{C}$ & . & 1 & . & . & . & + & . & 1 & + & 1 & 1 & 1 & 1 & 1 & . & . & . \\
\hline $\mathrm{C}$ & + & + & + & . & . & $\cdot$ & . & 1 & + & . & + & . & . & + & + & + & . \\
\hline $\mathrm{C}$ & 1 & + & + & + & + & . & 1 & + & + & . & . & . & . & . & . & . & . \\
\hline $\mathrm{C}$ & 1 & + & + & + & + & . & + & . & . & . & + & . & . & . & . & . & . \\
\hline $\mathrm{C}$ & . & + & . & . & + & . & . & + & . & . & 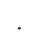 & . & . & . & + & + & . \\
\hline $\mathrm{C}$ & . & . & . & + & . & . & . & . & + & 1 & 1 & . & . & + & . & . & . \\
\hline $\mathrm{C}$ & . & . & . & + & . & . & . & + & + & . & + & . & . & . & . & + & . \\
\hline $\mathrm{C}$ & 1 & . & . & . & . & . & . & . & . & . & . & 1 & + & . & . & 1 & . \\
\hline $\mathrm{C}$ & + & . & . & . & . & . & . & + & . & . & . & . & . & . & + & + & . \\
\hline $\mathrm{C}$ & + & . & . & . & . & . & . & . & + & + & . & . & . & . & . & . & . \\
\hline $\mathrm{C}$ & + & . & . & . & . & . & . & . & . & . & . & . & $\cdot$ & + & . & . & . \\
\hline $\mathrm{C}$ & 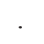 & . & . & . & . & . & . & . & + & . & 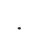 & . & . & 1 & . & . & . \\
\hline $\mathrm{C}$ & + & . & . & . & . & . & . & + & . & . & . & . & . & . & . & . & . \\
\hline C & + & . & . & . & . & . & . & + & . & . & . & . & . & . & . & . & . \\
\hline C & + & . & . & . & . & . & . & . & . & . & . & . & . & . & . & + & . \\
\hline C & . & . & . & . & . & . & . & + & . & + & . & . & . & . & . & . & . \\
\hline
\end{tabular}

QF Querco-Fagetea

Anemone nemorosa

Carex digitata

Hepatica nobilis

Primula vulgaris

Clematis vitalba

Platanthera bifolia

Corylus avellana

Lonicera xylosteum

Taxus baccata

EP Erico-Pinetea

Cirsium erisithales

Rhododendron hirsutum

Rubus saxatilis

VP Vaccinio-Piceetea

Abies alba

\begin{tabular}{|c|c|c|c|c|c|c|c|c|c|c|c|c|c|c|c|c|c|}
\hline A & $\cdot$ & + & + & . & . & . & + & $\cdot$ & r & & & & + & & • & . & $\mathrm{r}$ \\
\hline B & + & . & . & + & . & . & . & . & . & . & & . & . & & 2 & . & + \\
\hline $\mathrm{C}$ & . & + & + & . & . & + & . & + & . & + & • & + & + & . & + & & . \\
\hline $\mathrm{C}$ & . & $\mathrm{r}$ & . & + & + & . & . & + & + & + & . & . & . & + & . & $\cdot$ & . \\
\hline $\mathrm{C}$ & . & . & . & . & . & . & . & + & + & . & + & + & + & & . & + & . \\
\hline B & + & $\mathrm{r}$ & . & . & . & . & . & $\mathrm{r}$ & . & ${ }^{\circ}$ & & . & . & & + & . & . \\
\hline & . & . & . & . & . & . & . & . & . & . & . & . & & & . & ${ }^{\circ}$ & . \\
\hline $\mathrm{C}$ & + & 1 & 1 & + & + & 1 & 1 & + & + & + & + & . & . & . & 1 & . & . \\
\hline $\mathrm{C}$ & 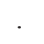 & . & + & . & + & + & . & . & + & + & . & + & + & + & . & . & + \\
\hline $\mathrm{C}$ & . & . & + & 1 & + & . & 1 & + & + & . & . & . & . & . & 1 & + & . \\
\hline $\mathrm{C}$ & + & . & . & . & . & . & . & $\mathrm{r}$ & 1 & 1 & 1 & 1 & 1 & + & . & . & . \\
\hline B & . & . & + & . & . & . & . & + & + & & & r & . & + & . & . & . \\
\hline $\mathrm{C}$ & 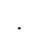 & . & + & + & . & . & . & $\mathrm{r}$ & . & & & . & . & . & . & . & + \\
\hline B & $\mathrm{r}$ & . & . & . & . & . & . & + & + & . & . & $\cdot$ & $\cdot$ & $\cdot$ & . & . & . \\
\hline B & + & . & . & . & . & . & . & . & . & . & & & . & . & + & . & $\mathrm{r}$ \\
\hline A & . & . & . & . & . & . & . & . & . & & & & $\mathrm{r}$ & & $\mathrm{r}$ & + & . \\
\hline $\mathrm{C}$ & + & 1 & 1 & + & 1 & + & + & + & 1 & 1 & r & 1 & 1 & + & + & 1 & . \\
\hline B & 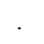 & + & $\mathrm{r}$ & $\mathrm{r}$ & $\mathrm{r}$ & . & . & . & . & & . & . & . & . & . & . & . \\
\hline $\mathrm{C}$ & . & . & . & + & + & . & . & . & . & . & . & . & . & . & . & . & . \\
\hline
\end{tabular}

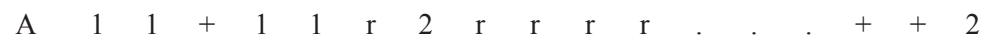

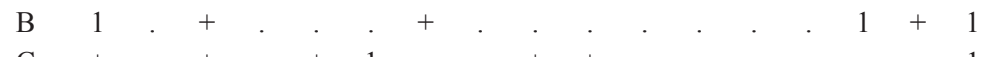




\begin{tabular}{|c|c|c|c|c|c|c|c|c|c|c|c|c|c|c|c|c|c|c|}
\hline Taxa & & 1 & 2 & 3 & $4 *$ & 5 & 6 & 7 & 8 & 9 & 10 & 11 & 12 & 13 & 14 & 15 & 16 & 17 \\
\hline Veronica urticifolia & $\mathrm{C}$ & + & 1 & 1 & 1 & + & + & 1 & + & . & + & 1 & 1 & 1 & . & + & . & + \\
\hline Valeriana tripteris & $\mathrm{C}$ & + & + & + & + & + & . & + & + & . & . & + & + & 1 & . & 1 & . & + \\
\hline Gentiana asclepiadea & $\mathrm{C}$ & + & + & 1 & + & + & . & + & . & + & + & + & . & + & . & + & . & . \\
\hline Solidago virgaurea & $\mathrm{C}$ & + & . & . & . & + & . & . & + & + & + & + & + & + & . & + & . & + \\
\hline Hieracium murorum & $\mathrm{C}$ & . & . & + & + & + & + & + & . & + & + & . & . & + & . & . & + & . \\
\hline Homogyne sylvestris & $\mathrm{C}$ & . & . & 1 & 1 & 1 & . & 1 & . & . & . & . & + & + & . & 1 & 1 & + \\
\hline Rosa pendulina & $\mathrm{C}$ & + & + & . & . & + & . & 1 & + & . & + & . & . & . & . & + & + & 1 \\
\hline Clematis alpina & $\mathrm{C}$ & + & + & + & + & . & . & 2 & . & . & . & . & . & . & . & + & + & + \\
\hline \multirow[t]{2}{*}{ Aposeris foetida } & $\mathrm{C}$ & . & . & . & . & . & . & . & + & 1 & 1 & 1 & 1 & 1 & + & . & . & . \\
\hline & $\mathrm{A}$ & . & . & . & . & $\mathrm{r}$ & $\mathrm{r}$ & . & . & $\mathrm{r}$ & . & . & . & . & . & + & $\mathrm{r}$ & $\mathrm{r}$ \\
\hline \multirow[t]{2}{*}{ Picea abies } & $\mathrm{B}$ & + & + & + & . & . & . & . & $\mathrm{r}$ & $\mathrm{r}$ & . & . & . & . & . & 1 & . & + \\
\hline & $\mathrm{C}$ & . & . & + & + & . & . & . & . & . & . & . & . & + & . & + & . & . \\
\hline Maianthemum bifolium & $\mathrm{C}$ & . & + & . & . & . & + & + & . & . & . & . & . & . & . & + & . & . \\
\hline Vaccinium myrtillus & $\mathrm{C}$ & + & . & . & . & . & . & . & . & . & . & . & . & + & . & + & . & 1 \\
\hline Lonicera nigra & $\mathrm{B}$ & . & . & . & . & . & . & . & $\mathrm{r}$ & . & . & . & . & . & . & + & . & + \\
\hline Oxalis acetosella & $\mathrm{C}$ & + & . & . & . & . & . & + & . & . & . & . & . & . & . & + & . & . \\
\hline Calamagrostis arundinacea & $\mathrm{C}$ & + & . & . & . & . & . & + & . & . & . & $\cdot$ & . & . & . & . & . & . \\
\hline Huperzia selago & $\mathrm{C}$ & . & . & . & . & + & . & + & . & . & . & . & . & . & . & . & . & . \\
\hline Rubus hirtus & $\mathrm{B}$ & . & + & . & . & . & . & . & . & . & . & . & . & . & . & . & + & . \\
\hline \multicolumn{19}{|l|}{ MA Mulgedio-Aconitetea } \\
\hline Senecio ovatus & $\mathrm{C}$ & 1 & 1 & + & + & + & 1 & + & + & . & 1 & 1 & 1 & . & 1 & . & + & + \\
\hline Polygonatum verticillatum & $\mathrm{C}$ & . & 1 & 1 & 1 & + & . & + & 1 & + & + & + & + & . & . & . & . & + \\
\hline Athyrium filix-femina & $\mathrm{C}$ & + & . & + & . & + & . & . & + & + & . & . & . & . & . & . & . & . \\
\hline Aconitum lycoctonum & $\mathrm{C}$ & . & . & . & . & . & . & . & + & 1 & . & 1 & 1 & . & . & . & . & . \\
\hline Centaurea montana & $\mathrm{C}$ & . & . & . & . & . & . & . & . & + & + & . & . & + & . & . & + & . \\
\hline Heracleum sphondylium & $\mathrm{C}$ & . & + & . & . & . & + & . & + & . & . & . & . & . & . & + & . & . \\
\hline Veratrum album & $\mathrm{C}$ & + & . & 1 & + & . & . & . & . & . & . & . & . & . & . & 1 & . & . \\
\hline Aconitum degenii/paniculatum & $\mathrm{C}$ & . & . & . & . & . & . & . & . & + & . & . & . & . & + & + & . & . \\
\hline Geranium robertianum & $\mathrm{C}$ & + & . & . & . & . & . & . & . & . & . & . & . & . & . & . & . & + \\
\hline Salix appendiculata & $\mathrm{B}$ & . & . & + & . & . & . & . & . & . & . & . & . & . & . & $\mathrm{r}$ & . & . \\
\hline \multicolumn{19}{|l|}{ ES Elyno-Seslerietea } \\
\hline Carex ferruginea & $\mathrm{C}$ & . & . & 1 & 1 & + & + & 1 & + & + & + & $\mathrm{r}$ & . & + & . & . & . & . \\
\hline Aster bellidiastrum & $\mathrm{C}$ & . & . & . & + & . & . & . & . & . & $\mathrm{r}$ & $\cdot$ & . & $\cdot$ & . & . & . & . \\
\hline Sesleria caerulea/calcaria & $\mathrm{C}$ & . & . & . & + & + & . & . & . & . & . & . & . & . & . & . & . & . \\
\hline \multicolumn{19}{|l|}{ AT Asplenietea trichomanis } \\
\hline Asplenium viride & $\mathrm{C}$ & . & . & + & + & + & + & 1 & + & + & $\mathrm{r}$ & . & . & . & + & + & . & . \\
\hline Asplenium ruta-muraria & $\mathrm{C}$ & . & . & . & . & . & . & . & . & . & + & . & . & + & + & + & + & + \\
\hline Asplenium trichomanes & $\mathrm{C}$ & . & . & . & . & . & . & . & + & + & . & + & . & . & . & + & . & + \\
\hline Cystopteris fragilis & $\mathrm{C}$ & . & . & . & . & . & + & + & . & . & . & + & . & . & . & . & . & . \\
\hline Moehringia muscosa & $\mathrm{C}$ & + & . & . & . & + & . & . & . & . & . & . & . & . & . & . & . & + \\
\hline Polypodium vulgare & $\mathrm{C}$ & + & + & . & . & . & . & . & . & . & . & $\cdot$ & . & . & . & . & . & . \\
\hline \multicolumn{19}{|l|}{ TR Thlaspietea rotundifoliae } \\
\hline Adenostyles glabra & $\mathrm{C}$ & + & 1 & 1 & 2 & 1 & 1 & 1 & 1 & 1 & 1 & 1 & . & . & 1 & + & 1 & + \\
\hline Gymnocarpium robertianum & $\mathrm{C}$ & . & . & . & + & + & . & . & + & + & . & $\cdot$ & . & . & . & + & + & $\cdot$ \\
\hline Astrantia carniolica & $\mathrm{C}$ & . & . & . & 1 & . & . & . & . & . & . & $\cdot$ & . & . & . & . & . & . \\
\hline \multicolumn{19}{|l|}{ TG Trifolio-Geranietea } \\
\hline Vincetoxicum hirundinaria & $\mathrm{C}$ & . & $\mathrm{r}$ & . & . & . & . & 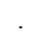 & . & $\mathrm{r}$ & . & . & . & . & + & . & . & . \\
\hline Clinopodium vulgare & $\mathrm{C}$ & . & . & . & . & . & . & . & . & + & . & . & . & . & + & . & . & . \\
\hline Other taxa & & . & . & . & . & . & . & . & . & . & . & . & . & . & . & . & . & . \\
\hline Eupatorium cannabinum & $\mathrm{C}$ & . & . & 1 & + & . & + & . & + & + & + & . & . & . & 1 & . & + & . \\
\hline Rubus idaeus & $\mathrm{B}$ & + & + & + & . & + & . & . & . & . & . & . & . & . & . & + & + & . \\
\hline
\end{tabular}




\begin{tabular}{|c|c|c|c|c|c|c|c|c|c|c|c|c|c|c|c|c|c|c|}
\hline Taxa & & 1 & 2 & 3 & $4 *$ & 5 & 6 & 7 & 8 & 9 & 10 & 11 & 12 & 13 & 14 & 15 & 16 & 17 \\
\hline Sorbus aucuparia & $\mathrm{C}$ & . & . & + & . & + & + & . & + & . & . & . & . & + & . & + & . & . \\
\hline Atropa bella-donna & $\mathrm{C}$ & . & $\mathrm{r}$ & . & . & . & . & . & . & . & . & . & . & . & + & . & . & . \\
\hline \multicolumn{19}{|l|}{ Lichens and mosses } \\
\hline Ctenidium molluscum & $\mathrm{D}$ & 1 & 1 & 1 & 1 & . & 1 & 1 & . & 1 & + & . & + & + & + & 2 & 1 & 1 \\
\hline Fissidens dubius & $\mathrm{D}$ & . & + & + & + & 1 & + & 1 & + & + & + & + & + & + & + & . & + & . \\
\hline Neckera crispa & $\mathrm{D}$ & 1 & + & + & . & + & . & . & + & . & + & . & + & + & . & 1 & 1 & 1 \\
\hline Tortella tortuosa & $\mathrm{D}$ & + & + & 1 & + & + & + & 1 & . & . & . & + & . & + & . & + & . & + \\
\hline Schistidium apocarpum & $\mathrm{D}$ & . & + & . & . & . & + & 1 & + & + & . & + & + & . & . & 1 & . & + \\
\hline Polytrichum formosum & $\mathrm{D}$ & + & . & + & . & + & + & 1 & . & . & . & + & . & + & . & + & . & . \\
\hline Plagiochila porelloides & $\mathrm{D}$ & . & + & 1 & . & . & . & + & . & . & . & . & . & . & . & + & . & + \\
\hline Dicranum scoparium & $\mathrm{D}$ & . & . & . & + & . & . & + & . & . & . & . & . & . & . & . & . & + \\
\hline Encalypta streptocarpa & $\mathrm{D}$ & . & . & . & . & . & . & . & . & . & + & . & + & . & + & . & . & . \\
\hline Leucobryum glaucum & $\mathrm{D}$ & . & . & . & + & + & . & . & . & . & . & . & . & . & . & . & . & + \\
\hline Isothecium alopecuroides & $\mathrm{D}$ & + & . & . & . & . & . & + & . & . & . & . & . & . & . & . & . & . \\
\hline
\end{tabular}

Table 12:Analytical table of the subassociation Omphalodo-Fagetum var. geogr. Saxifraga cuneifolia seslerietosum autumnalis subass. nova in the Trnovski gozd plateau (NW Dinaric Alps; complete linkage, Euclidian distances).

Tabela 12: Analizna tabela subasociacije Omphalodo-Fagetum var. geogr. Saxifraga cuneifolia seslerietosum autumnalis subass. nova v Trnovskem gozdu (severozahodni Dinaridi; metoda popolnega povezovanja, Evklidske razdalje).

\begin{tabular}{|c|c|c|c|c|c|c|c|c|c|c|c|c|c|c|c|c|c|}
\hline Taxa & & 1 & 2 & 3* & 4 & 5 & $6^{*}$ & 7 & 8 & 9 & 10 & 11 & 12 & 13 & 14* & 15 & 16 \\
\hline \multicolumn{18}{|c|}{ Characteristic species of the association Omphalodo-Fagetum } \\
\hline AF Cardamine trifolia & $\mathrm{C}$ & + & + & 1 & + & + & + & 1 & 1 & 1 & + & 1 & + & + & + & + & . \\
\hline AF Aremonia agrimonoides & $\mathrm{C}$ & + & + & + & . & + & + & + & + & + & + & + & + & + & . & + & . \\
\hline AF Rhamnus fallax & $\mathrm{B}$ & + & . & . & . & . & . & . & . & . & . & + & . & . & . & . & . \\
\hline \multicolumn{18}{|c|}{ Differential species for the geographical variant Saxifraga cuneifolia } \\
\hline VP Saxifraga cuneifolia & $\mathrm{C}$ & . & . & . & . & . & . & . & . & . & . & . & . & + & . & . & + \\
\hline AT Phyteuma scheuchzeri/columnae & $\mathrm{C}$ & . & . & . & . & . & . & . & . & . & . & + & . & . & + & . & 1 \\
\hline FS Laburnum alpinum & $\mathrm{C}$ & . & . & + & . & . & . & . & . & . & . & . & . & . & . & . & . \\
\hline \multicolumn{18}{|c|}{ Differential species for the subassociation -seslerietosum autumnalis } \\
\hline QP Sesleria autumnalis & $\mathrm{C}$ & 3 & 3 & 5 & 3 & 2 & 3 & 1 & 2 & 3 & 3 & 3 & 4 & 3 & 4 & 4 & 5 \\
\hline FS Lathyrus vernus/vernus & $\mathrm{C}$ & + & . & + & 1 & . & . & + & + & + & + & 1 & + & + & + & + & 1 \\
\hline FS Lathyrus vernus/flaccidus & $\mathrm{C}$ & . & + & + & . & . & . & . & . & . & . & 1 & + & + & + & 1 & + \\
\hline \multicolumn{18}{|c|}{ Differential species for the elevational variants } \\
\hline QF Platanthera bifolia & $\mathrm{C}$ & + & . & . & + & + & + & + & + & . & + & . & . & . & . & . & . \\
\hline QP Fraxinus ornus & $\mathrm{B}$ & + & . & . & + & + & + & . & . & . & . & . & . & . & . & . & . \\
\hline QF Lonicera xylosteum & $\mathrm{B}$ & . & . & . & + & . & + & . & . & + & + & . & . & . & . & . & . \\
\hline MA Polygonatum verticillatum & $\mathrm{C}$ & . & 1 & + & . & . & . & . & . & . & . & + & + & + & 1 & 1 & + \\
\hline VP Rosa pendulina & $\mathrm{C}$ & + & . & + & . & . & . & + & + & . & . & . & + & + & 1 & 1 & 1 \\
\hline VP Huperzia selago & $\mathrm{C}$ & . & . & . & . & . & . & . & . & . & . & . & + & . & + & + & . \\
\hline TR Anthriscus fumarioides & $\mathrm{C}$ & . & . & . & . & . & . & . & . & . & . & . & 1 & + & 1 & + & . \\
\hline \multicolumn{18}{|l|}{ AF Aremonio-Fagion } \\
\hline Cardamine enneaphyllos & $\mathrm{C}$ & 2 & 2 & 2 & 1 & + & . & 1 & 2 & 1 & 2 & + & 1 & + & + & . & + \\
\hline Lamium orvala & $\mathrm{C}$ & + & + & + & + & + & + & + & + & + & + & + & + & + & . & . & . \\
\hline Cyclamen purpurascens & $\mathrm{C}$ & . & . & + & . & + & . & + & + & . & + & 1 & + & + & + & + & 2 \\
\hline Anemone trifolia & $\mathrm{C}$ & . & . & . & + & + & 1 & + & + & . & 1 & . & 1 & 2 & + & . & . \\
\hline Vicia oroboides & $\mathrm{C}$ & . & . & . & . & + & + & . & . & . & . & $\cdot$ & . & . & . & . & $\cdot$ \\
\hline
\end{tabular}


Taxa

$\begin{array}{llllllllllllllll}1 & 2 & 3 * & 4 & 5 & 6 * & 7 & 8 & 9 & 10 & 11 & 12 & 13 & 14 * & 15 & 16\end{array}$

FS Fagetalia sylvaticae

Fagus sylvatica

Mycelis muralis

Daphne mezereum

Dryopteris filix-mas

Galeobdolon flavidum

Mercurialis perennis

Galium odoratum

Prenanthes purpurea

Paris quadrifolia

Festuca altissima

Galium laevigatum

Sambucus nigra

Acer pseudoplatanus

Lonicera alpigena

Actaea spicata

Epipactis helleborine

Scrophularia nodosa

Viola reichenbachiana

Epilobium montanum

Neottia nidus-avis

Polygonatum multiflorum

Tilia platyphyllos

Polystichum aculeatum

Ranunculus lanuginosus

Salvia glutinosa

Carex sylvatica

Cephalanthera damasonium

Cardamine bulbifera

Sanicula europaea

QP Quercetalia pubescentis

Sorbus aria

Convallaria majalis

QF Querco-Fagetea

Anemone nemorosa

Carex digitata

Hepatica nobilis

Corylus avellana

Anemone x pittonii

\section{VP Vaccinio-Piceetea}

Abies alba

Calamagrostis arundinacea

Luzula luzuloides
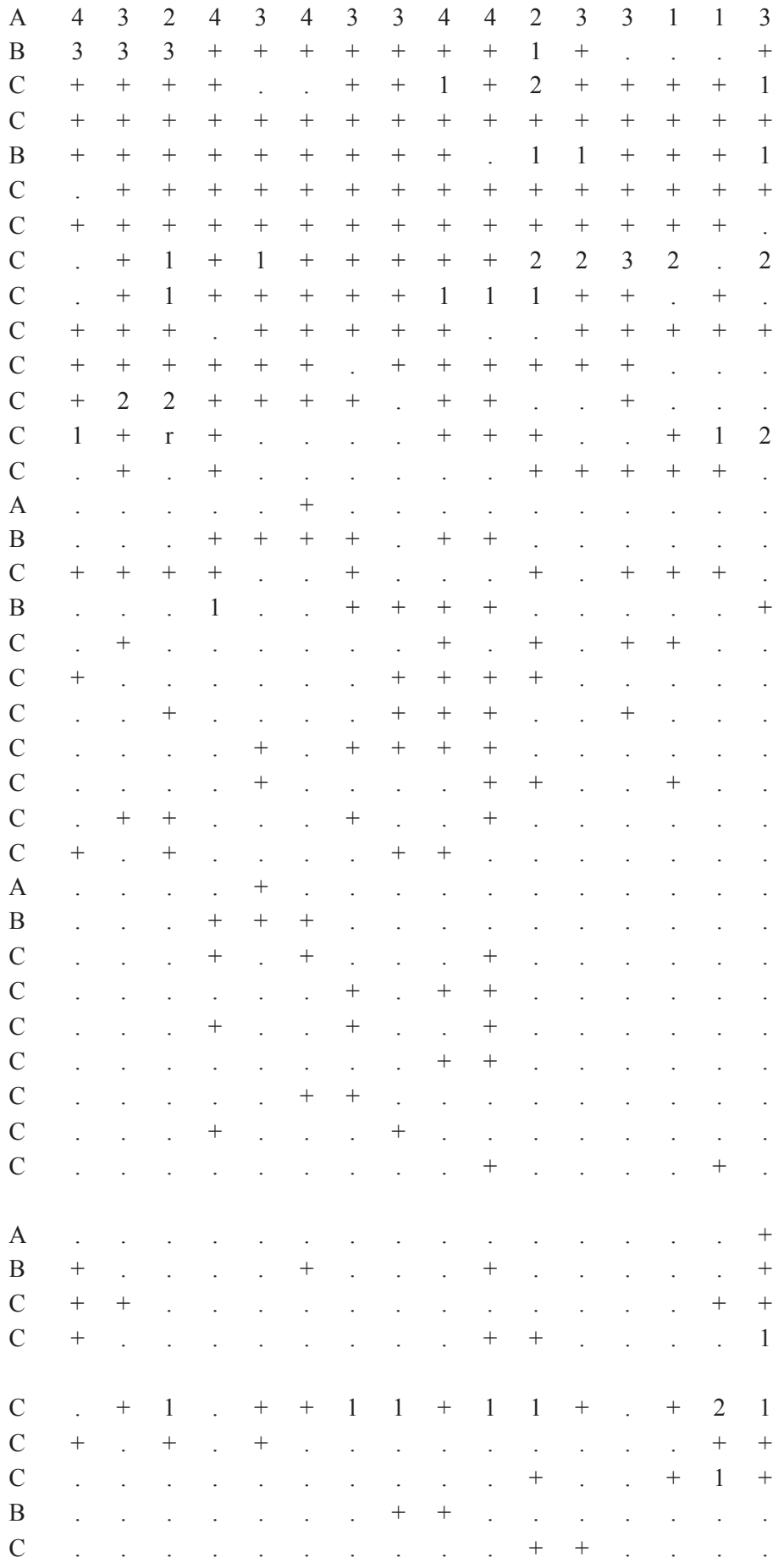

$\begin{array}{lllllllllllllllll}\mathrm{A} & 2 & 4 & 4 & 1 & 3 & 1 & 2 & 3 & 2 & 2 & 3 & 2 & 2 & 4 & 4 & 2\end{array}$

$\mathrm{B}$. . $++++++1+$. . .

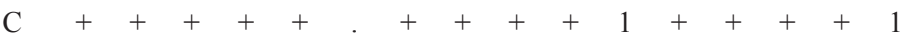

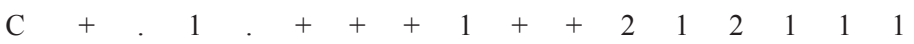

C $1+++++++++$ + . +1 


\begin{tabular}{|c|c|c|c|c|c|c|c|c|c|c|c|c|c|c|c|c|c|}
\hline Taxa & & 1 & 2 & $3^{*}$ & 4 & 5 & $6^{*}$ & 7 & 8 & 9 & 10 & 11 & 12 & 13 & $14 *$ & 15 & 16 \\
\hline Maianthemum bifolium & $\mathrm{C}$ & 1 & + & 2 & + & + & + & + & + & + & + & 1 & + & . & . & 2 & 2 \\
\hline Oxalis acetosella & $\mathrm{C}$ & + & 3 & 1 & 1 & 1 & 1 & 1 & . & + & 1 & 1 & . & + & + & + & . \\
\hline \multirow[t]{2}{*}{ Solidago virgaurea } & $\mathrm{C}$ & + & . & . & . & . & . & + & . & + & + & . & + & + & + & + & + \\
\hline & A & . & . & . & . & . & . & 1 & . & + & + & . & . & . & . & + & . \\
\hline \multirow[t]{2}{*}{ Picea abies } & $\mathrm{B}$ & . & . & . & & . & . & . & . & . & . & . & . & . & . & + & . \\
\hline & $\mathrm{C}$ & + & . & $\mathrm{r}$ & & . & . & . & & . & . & + & + & + & . & + & + \\
\hline Gentiana asclepiadea & $\mathrm{C}$ & . & . & + & . & . & + & . & . & + & + & . & . & . & + & + & . \\
\hline Valeriana tripteris & $\mathrm{C}$ & + & . & . & . & . & . & . & . & . & . & . & . & . & + & + & + \\
\hline Lonicera nigra & $\mathrm{B}$ & + & . & . & . & . & + & . & . & . & + & . & . & . & . & . & . \\
\hline Clematis alpina & $\mathrm{C}$ & . & . & . & . & . & . & . & . & . & . & + & . & . & . & 1 & + \\
\hline Dryopteris expansa & $\mathrm{C}$ & . & . & + & + & . & . & . & . & . & . & . & . & . & . & . & . \\
\hline \multicolumn{18}{|l|}{ A Mulgedio-Aconitetea } \\
\hline Senecio ovatus & $\mathrm{C}$ & + & 1 & + & 1 & + & + & + & + & 1 & + & 1 & + & + & + & + & . \\
\hline Geranium robertianum & $\mathrm{C}$ & . & + & . & + & . & + & + & . & + & . & + & + & + & + & + & + \\
\hline Athyrium filix-femina & $\mathrm{C}$ & . & + & + & . & . & . & . & + & . & . & + & . & . & + & + & . \\
\hline Urtica dioica & $\mathrm{C}$ & . & + & . & . & . & . & . & . & . & . & . & . & . & + & . & . \\
\hline Asplenietea trichomanis & & . & . & . & . & . & . & . & . & . & . & . & . & . & . & . & . \\
\hline Asplenium trichomanes & $\mathrm{C}$ & . & + & . & + & + & . & . & . & + & . & + & + & + & + & + & + \\
\hline Asplenium ruta-muraria & $\mathrm{C}$ & + & . & + & . & + & . & . & . & . & . & + & + & . & + & 1 & + \\
\hline Asplenium viride & $\mathrm{C}$ & + & . & + & . & . & . & . & . & . & + & + & + & + & . & + & . \\
\hline Moehringia muscosa & $\mathrm{C}$ & + & . & . & + & . & . & + & . & . & . & + & + & . & . & + & + \\
\hline Polypodium vulgare & $\mathrm{C}$ & + & . & . & + & + & + & . & . & . & . & + & + & + & . & . & . \\
\hline Cymbalaria muralis & $\mathrm{C}$ & . & . & . & 1 & . & . & . & . & . & . & . & . & . & . & + & . \\
\hline \multicolumn{18}{|l|}{$\mathrm{R}$ Thlaspietea rotundifolii } \\
\hline Adenostyles glabra & $\mathrm{C}$ & + & 1 & + & + & + & + & + & 1 & 1 & 1 & + & + & + & + & 1 & . \\
\hline \multicolumn{18}{|c|}{ 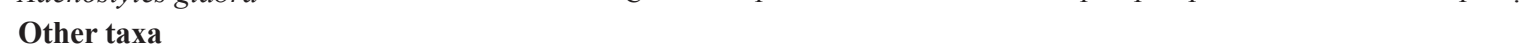 } \\
\hline Rubus idaeus & $\mathrm{B}$ & + & 1 & 1 & + & . & . & + & + & . & . & 1 & 1 & + & + & + & . \\
\hline Solanum dulcamara & $\mathrm{C}$ & + & & . & . & & & + & . & & . & . & + & 1 & 1 & + & + \\
\hline \multirow{2}{*}{ Sorbus aucuparia } & $\mathrm{B}$ & . & . & + & . & + & & . & . & & . & + & . & & & + & . \\
\hline & $\mathrm{C}$ & + & . & + & . & + & . & . & . & . & . & + & . & . & . & . & + \\
\hline Fragaria vesca & $\mathrm{C}$ & + & . & . & . & . & . & . & . & . & + & + & + & . & . & . & . \\
\hline Sambucus racemosa & $\mathrm{B}$ & . & . & . & . & . & . & . & . & . & . & . & . & . & + & . & + \\
\hline \multicolumn{18}{|l|}{ Lichens and mosses } \\
\hline Ctenidium molluscum & $\mathrm{D}$ & 1 & 2 & 1 & . & 1 & 1 & 2 & 1 & + & + & 1 & 2 & 2 & 3 & 2 & . \\
\hline Neckera crispa & $\mathrm{D}$ & 1 & 1 & + & . & + & + & 1 & 1 & + & + & . & 2 & 1 & 2 & 2 & . \\
\hline Grimmia pulvinata & $\mathrm{D}$ & + & + & + & . & + & . & + & + & + & + & . & + & . & + & . & . \\
\hline Tortella tortuosa & $\mathrm{D}$ & . & . & . & . & + & + & . & + & + & . & . & + & + & + & + & . \\
\hline Cladonia pyxidata & $\mathrm{D}$ & . & + & + & . & . & . & + & . & . & . & . & + & + & + & + & + \\
\hline Isothecium alopecuroides & $\mathrm{D}$ & . & . & . & . & + & + & + & + & + & + & . & . & . & . & . & . \\
\hline Hypnum cupressiforme & $\mathrm{D}$ & + & 1 & 1 & . & . & . & . & . & . & . & . & + & 1 & . & . & . \\
\hline Plagiochila asplenioides & $\mathrm{D}$ & . & 1 & . & . & . & . & + & . & + & + & . & . & . & . & + & . \\
\hline Camptothecium lutescens & $\mathrm{D}$ & . & . & . & . & + & & + & . & + & + & . & . & & & . & . \\
\hline Cladonia coniocraea & $\mathrm{D}$ & & . & . & . & . & . & . & . & . & . & . & . & + & . & + & + \\
\hline Dicranum scoparium & $\mathrm{D}$ & & & . & . & e & . & . & . & . & & . & . & 1 & + & . & . \\
\hline Plagiothecium sylvaticum & $\mathrm{D}$ & · & . & . & . & . & . & + & . & + & . & . & . & . & . & . & . \\
\hline Cladonia digitata & $\mathrm{D}$ & & & . & . & & & . & . & & & . & + & + & & . & \\
\hline
\end{tabular}


Table 13: Analytical table of the subassociation Omphalodo-Fagetum var. geogr. Calamintha grandiflora sambucetosum nigrae subass. nova in the Trnovski gozd plateau (NW Dinaric Alps; complete linkage, Euclidian distances).

Tabela 13: Analizna tabela subasociacije Omphalodo-Fagetum var. geogr. Calamintha grandiflora sambucetosum nigrae subass. nova v Trnovskem gozdu (severozahodni Dinaridi; metoda popolnega povezovanja, Evklidske razdalje).

\begin{tabular}{|c|c|c|c|c|c|c|c|c|}
\hline & Taxa & & 1 & 2 & 3* & 4 & 5 & 6 \\
\hline \multicolumn{9}{|c|}{ Characteristic species of the association Omphalodo-Fagetum } \\
\hline $\mathrm{AF}$ & Omphalodes verna & $\mathrm{C}$ & 2 & 2 & 2 & 2 & 3 & \\
\hline $\mathrm{AF}$ & Cardamine trifolia & $\mathrm{C}$ & 1 & 1 & 1 & 1 & 1 & \\
\hline $\mathrm{AF}$ & Calamintha grandiflora & $\mathrm{C}$ & 1 & + & $\mathrm{r}$ & 1 & 1 & 1 \\
\hline $\mathrm{AF}$ & Aremonia agrimonoides & $\mathrm{C}$ & + & 1 & + & + & + & + \\
\hline
\end{tabular}

Differential species for the geographical variant Calamintha grandiflora

AF Omphalodes verna $\quad \mathrm{C} \quad \begin{array}{llllll}2 & 2 & 2 & 2 & 3 & 2\end{array}$

AF Calamintha grandiflora $\quad \mathrm{C} \quad 1+\mathrm{r} \quad \begin{array}{lll}1 & 1 & 1\end{array}$

Differential species for the subassociation sambucetosum nigrae

FS Sambucus nigra $\mathrm{C}+1+1+1+$

FS Euphorbia amygdaloides $\quad \mathrm{C} 1 .+++{ }_{+}+$

FS Tilia platyphyllos $\mathrm{B}+.+{ }^{+}+{ }_{+}$.

AF Aremonio-Fagion

Cyclamen purpurascens

Cardamine enneaphyllos

Euphorbia carniolica

Lamium orvala

C . . + . . .

FS Fagetalia sylvaticae

Fagus sylvatica

Acer pseudoplatanus

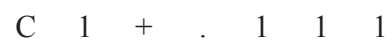

$\mathrm{C}++.++1$

$\mathrm{C} \cdot++++1$

C. . + . $1+$

Actaea spicata

Daphne mezereum

Dryopteris filix-mas

Epipactis helleborine

$\begin{array}{lllllll}\mathrm{A} & 2 & 3 & 2 & 4 & 4 & 4\end{array}$

Festuca altissima

Mercurialis perennis

Mycelis muralis

Paris quadrifolia

Prenanthes purpurea

Carex sylvatica

Galeobdolon flavidum

Neottia nidus-avis

Polystichum aculeatum

Sanicula europaea

Galium odoratum

Salvia glutinosa

Cardamine pentaphyllos

Epilobium montanum

$\begin{array}{lllllll}\mathrm{B} & 2 & 3 & 2 & 3 & 3 & 2\end{array}$

C $1+++1+$

$\mathrm{A}+1$. . .

$\begin{array}{lllllll}\mathrm{B} & 1 & 1 & 1 & 2 & 2\end{array}$

$\begin{array}{lllllll}\mathrm{C} & 2 & 2 & 2 & 2 & 2 & 1\end{array}$

$\mathrm{C}++++++$

$\begin{array}{lllllll}\mathrm{B} & 1 & 2 & 1 & 1 & 1 & +\end{array}$

$\mathrm{C}+1++++$

$\mathrm{C}+++++\mathrm{r}$

C $12+1 \quad 1+$

$\begin{array}{lllllll}\mathrm{C} & 2 & 2 & 1 & 2 & 2 & 2\end{array}$

C $1+++++$

$\mathrm{C}++++++$

$\begin{array}{lllllll}\mathrm{C} & 1 & 1 & 1 & 1 & 1 & 1\end{array}$

$\mathrm{C}+++++$.

$\begin{array}{lllllll}\mathrm{C} & 1 & 1 & \cdot & 1 & 1 & 1\end{array}$

$\mathrm{C}++$. + r

$\mathrm{C}+1+$. +

C $1 .++++$

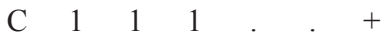

$\mathrm{C}+$. 1 . +

Fraxinus excelsior

$\mathrm{C} .2 .+1$

Galium laevigatum 


\begin{tabular}{|c|c|c|c|c|c|c|c|c|}
\hline & Taxa & & 1 & 2 & $3 *$ & 4 & 5 & 6 \\
\hline & Lonicera alpigena & $\mathrm{B}$ & 1 & + & . & + & . & . \\
\hline & Viola reichenbachiana & $\mathrm{C}$ & + & + & . & . & + & . \\
\hline & Laburnum alpinum & $\mathrm{C}$ & . & . & . & . & + & . \\
\hline \multirow[t]{3}{*}{ QP } & Quercetalia pubescentis & & & & & & & \\
\hline & Sorbus aria & B & + & $\cdot$ & . & + & . & + \\
\hline & & $\mathrm{C}$ & + & . & . & + & . & . \\
\hline \multirow[t]{7}{*}{ QF } & Querco-Fagetea & & & & & & & \\
\hline & Anemone nemorosa & $\mathrm{C}$ & 1 & 1 & 1 & . & + & + \\
\hline & Platanthera bifolia & $\mathrm{C}$ & + & . & + & 1 & + & + \\
\hline & Clematis vitalba & $\mathrm{B}$ & + & + & . & + & + & . \\
\hline & Carex digitata & $\mathrm{C}$ & + & . & . & . & + & $\mathrm{r}$ \\
\hline & Corvlus avellana & B & $\cdot$ & . & . & + & + & . \\
\hline & & $\mathrm{C}$ & . & . & . & 1 & + & + \\
\hline \multirow[t]{3}{*}{ EP } & Erico-Pinetea & & & & & & & \\
\hline & Rubus saxatilis & $\mathrm{C}$ & + & 1 & + & + & . & . \\
\hline & Calamagrostis varia & $\mathrm{C}$ & + & . & . & + & + & . \\
\hline
\end{tabular}

VP Vaccinio-Piceetea

Abies alba

$\begin{array}{lllllll}\mathrm{A} & 4 & 3 & 3 & 2 & 3 & 2\end{array}$

Gentiana asclepiadea

$\mathrm{B}$. . . . +

$\mathrm{C}+\quad \begin{array}{llll} & 1 & 2 & 2\end{array}$

Maianthemum bifolium

$\mathrm{C}+++++1$

Oxalis acetosella

$\begin{array}{lllllll}\mathrm{C} & 1 & 1 & 1 & 2 & 2 & 1\end{array}$

C $111+21$

Picea abies

$\mathrm{A}+1+11+$

$\mathrm{B}+$. . + .

Solidago virgaurea

$\mathrm{C}+1.11$

Dryopteris dilatata

$\mathrm{C} 11+21+$

Lonicera nigra

$\mathrm{C}+++$. +

Veronica urticifolia

$\mathrm{B} \cdot 1+1+1$

Rosa pendulina

C . $1++++$

$\mathrm{C}+1$. 1 .

Homogyne sylvestris

$\mathrm{C} .+1$.

Huperzia selago

Valeriana tripteris

$\mathrm{C}$. . . ++

$\mathrm{C} . \quad \mathrm{r}+$.

MA Mulgedio-Aconitetea

Athyrium filix-femina

Polygonatum verticillatum

$\mathrm{C}+1++2+$

Senecio ovatus

$\mathrm{C}+++1++$

Salix appendiculata

$\begin{array}{llllllll}\mathrm{C} & 2 & 2 & 1 & 2 & 1\end{array}$

$\mathrm{B} . .++$.

AT Asplenietea trichomanis

Asplenium trichomanes

Asplenium viride

Cystopteris fragilis

\section{Other taxa}

Sorbus aucuparia

Rubus idaeus

Solanum dulcamara

Eupatorium cannabinum

Fragaria vesca

Rubus fruticosus agg.

$\mathrm{C}++++++$

$\mathrm{C}++++++$

$\mathrm{C} .+{ }^{+}+$

$\mathrm{B}$. ..+1

$\mathrm{C}++++++$

$\mathrm{B}++++1+$

$\mathrm{C}+++.++$

$\mathrm{C}+$. +++

$\mathrm{C}++$. . .

C . $1 .+$. 


\begin{tabular}{|c|c|c|c|c|c|c|c|}
\hline Taxa & & 1 & 2 & $3 *$ & 4 & 5 & 6 \\
\hline \multicolumn{8}{|l|}{ Lichens and mosses } \\
\hline Plagiochila asplenioides & $\mathrm{D}$ & + & + & + & + & + & + \\
\hline Ctenidium molluscum & $\mathrm{D}$ & 1 & 2 & . & 1 & 2 & 1 \\
\hline Grimmia pulvinata & $\mathrm{D}$ & + & . & . & . & + & + \\
\hline Neckera crispa & $\mathrm{D}$ & 1 & . & + & . & + & . \\
\hline Tortella tortuosa & $\mathrm{D}$ & + & . & . & . & + & + \\
\hline Cladonia coniocraea & $\mathrm{D}$ & . & + & . & . & + & + \\
\hline Atrichum undulatum & $\mathrm{D}$ & . & . & . & . & 1 & + \\
\hline Hypnum cupressiforme & $\mathrm{D}$ & 2 & . & 2 & . & . & . \\
\hline Polytrichum formosum & $\mathrm{D}$ & . & . & . & . & 1 & + \\
\hline
\end{tabular}

Table 14: Analytical table of the subassociation Omphalodo-Fagetum var. geogr. Calamintha grandiflora asaretosum europaei Puncer 1980 var. Symphytum tuberosum var. nova in the Trnovski gozd plateau (NW Dinaric Alps; complete linkage, Euclidian distances).

Tabela 14: Analizna tabela subasociacije Omphalodo-Fagetum var. geogr. Calamintha grandiflora asaretosum europaei Puncer 1980 var. Symphytum tuberosum var. nova v Trnovskem gozdu (severozahodni Dinaridi; metoda popolnega povezovanja, Evklidske razdalje).

\begin{tabular}{|c|c|c|c|c|c|c|c|c|c|c|}
\hline & Taxa & & 1 & 2 & $3 *$ & 4 & 5 & 6 & 7 & 8 \\
\hline & \multicolumn{10}{|c|}{ Characteristic species of the association Omphalodo-Fagetum } \\
\hline $\mathrm{AF}$ & Omphalodes verna & $\mathrm{C}$ & + & + & + & 1 & $\mathrm{r}$ & + & 1 & . \\
\hline $\mathrm{AF}$ & Cardamine trifolia & $\mathrm{C}$ & + & . & + & + & + & + & . & + \\
\hline $\mathrm{AF}$ & Calamintha grandiflora & $\mathrm{C}$ & . & . & 1 & . & + & 1 & + & + \\
\hline $\mathrm{AF}$ & Aremonia agrimonoides & $\mathrm{C}$ & . & . & + & . & + & . & . & . \\
\hline \multicolumn{11}{|c|}{ Differential species for the geographical variant Calamintha grandiflora } \\
\hline $\mathrm{AF}$ & Omphalodes verna & $\mathrm{C}$ & + & + & + & 1 & $\mathrm{r}$ & + & 1 & . \\
\hline $\mathrm{AF}$ & Calamintha grandiflora & $\mathrm{C}$ & . & . & 1 & . & + & 1 & + & + \\
\hline \multicolumn{11}{|c|}{ Differential species combination for the subassociation -asaretosum } \\
\hline FS & Asarum europaeum/caucasicum & $\mathrm{C}$ & 1 & 1 & 1 & + & 1 & 1 & 1 & 1 \\
\hline \multirow[t]{2}{*}{ FS } & Pulmonaria officinalis & $\mathrm{C}$ & 1 & + & + & 1 & + & 1 & + & 1 \\
\hline & & A & $\mathrm{r}$ & 1 & 2 & . & + & 1 & 2 & 1 \\
\hline \multirow[t]{2}{*}{ FS } & Ulmus glabra & $\mathrm{B}$ & + & . & . & + & . & 1 & + & . \\
\hline & & $\mathrm{C}$ & + & + & . & + & + & 1 & + & + \\
\hline $\mathrm{QF}$ & Hedera helix & $\mathrm{C}$ & 1 & + & + & + & + & . & . & + \\
\hline $\mathrm{QF}$ & Carex digitata & $\mathrm{C}$ & + & + & + & + & + & + & . & . \\
\hline \multirow[t]{2}{*}{ QF } & Primula vulgaris & $\mathrm{C}$ & + & . & + & + & + & + & + & . \\
\hline & Differential species of the varia & & & & & & & & & \\
\hline FS & Symphytum tuberosum & $\mathrm{C}$ & 1 & + & 1 & 1 & + & . & + & 1 \\
\hline FS & Petasites albus & $\mathrm{C}$ & + & . & + & + & . & 1 & 2 & 2 \\
\hline \multirow[t]{7}{*}{$\mathrm{AF}$} & Aremonio-Fagion & & & & & & & & & \\
\hline & Daphne laureola & $\mathrm{B}$ & 1 & 1 & + & + & + & + & + & + \\
\hline & Lamium orvala & $\mathrm{C}$ & + & + & 1 & 2 & + & 1 & 2 & 2 \\
\hline & Cyclamen purpurascens & $\mathrm{C}$ & + & + & . & + & 1 & + & . & $\cdot$ \\
\hline & Scopolia carniolica & $\mathrm{C}$ & . & . & + & . & . & . & + & 1 \\
\hline & Hacquetia epipactis & $\mathrm{C}$ & + & . & + & . & . & . & . & . \\
\hline & Polystichum setiferum & $\mathrm{C}$ & . & . & . & . & . & . & + & + \\
\hline
\end{tabular}

FS Fagetalia sylvaticae

Fagus sylvatica

$\begin{array}{lllllllll}\mathrm{A} & 1 & 2 & 1 & 3 & 4 & 4 & 4 & 4 \\ \mathrm{~B} & 1 & 1 & 1 & 1 & + & 1 & 1 & . \\ \mathrm{C} & + & + & . & 1 & . & 1 & 1 & 1\end{array}$




\begin{tabular}{|c|c|c|c|c|c|c|c|c|c|c|}
\hline & Taxa & & 1 & 2 & $3 *$ & 4 & 5 & 6 & 7 & 8 \\
\hline & Actaea spicata & $\mathrm{C}$ & + & + & + & 1 & + & 1 & + & 1 \\
\hline & Dryopteris filix-mas & $\mathrm{C}$ & + & + & 1 & + & + & 1 & 1 & + \\
\hline & Paris quadrifolia & $\mathrm{C}$ & + & + & + & + & + & + & + & + \\
\hline & Salvia glutinosa & $\mathrm{C}$ & 1 & 1 & + & 1 & + & 1 & 1 & + \\
\hline & & A & 1 & 1 & 1 & 1 & + & 1 & 1 & . \\
\hline & Acer pseudoplatanus & B & + & . & . & . & . & + & . & . \\
\hline & & $\mathrm{C}$ & 1 & 1 & 1 & 1 & . & 1 & 1 & + \\
\hline & Polystichum aculeatum & $\mathrm{C}$ & 1 & + & 1 & 1 & 1 & 1 & . & + \\
\hline & Sanicula europaea & $\mathrm{C}$ & 1 & + & + & + & + & + & + & . \\
\hline & Carex sylvatica & $\mathrm{C}$ & + & . & 1 & + & + & + & + & . \\
\hline & & A & . & . & . & + & . & . & . & . \\
\hline & Fraxinus excelsior & B & . & . & + & + & . & + & . & . \\
\hline & & $\mathrm{C}$ & . & 1 & 1 & 1 & + & 1 & + & . \\
\hline & Galeobdolon flavidum & $\mathrm{C}$ & + & . & + & + & + & . & + & + \\
\hline & Prenanthes purpurea & $\mathrm{C}$ & + & + & + & + & . & . & + & 1 \\
\hline & Viola reichenbachiana & $\mathrm{C}$ & + & . & + & + & + & + & + & . \\
\hline & Campanula trachelium & $\mathrm{C}$ & + & + & . & . & + & + & + & . \\
\hline & & A & $r$ & + & + & + & + & . & . & . \\
\hline & Prunus avium & $\mathrm{C}$ & + & . & . & + & + & . & . & . \\
\hline & Daphne mezereum & B & . & + & + & + & + & . & . & . \\
\hline & Galium laevigatum & $\mathrm{C}$ & . & . & + & . & + & + & + & . \\
\hline & Galium odoratum & $\mathrm{C}$ & . & . & + & . & . & + & 1 & 1 \\
\hline & Mercurialis perennis & $\mathrm{C}$ & . & 2 & . & . & 1 & + & + & . \\
\hline & Mycelis muralis & $\mathrm{C}$ & + & . & + & . & + & + & . & . \\
\hline & Phyllitis scolopendrium & $\mathrm{C}$ & $r$ & . & + & . & . & . & + & + \\
\hline & Sambucus nigra & $\mathrm{C}$ & . & . & + & . & . & + & + & 1 \\
\hline & Scrophularia nodosa & $\mathrm{C}$ & . & . & . & + & . & + & + & + \\
\hline & & A & + & + & . & . & + & . & . & . \\
\hline & Acer campestre & B & . & . & + & . & . & . & . & . \\
\hline & & $\mathrm{C}$ & . & . & . & . & + & . & . & . \\
\hline & Arum maculatum & $\mathrm{C}$ & . & . & . & . & . & 1 & + & + \\
\hline & Aruncus dioicus & $\mathrm{C}$ & + & . & + & + & . & . & . & . \\
\hline & Cardamine bulbifera & $\mathrm{C}$ & . & . & . & . & . & + & 1 & 1 \\
\hline & Euphorbia amygdaloides & $\mathrm{C}$ & + & + & . & . & + & . & . & . \\
\hline & Fraxinus oxcolsior & A & . & . & . & + & . & . & . & . \\
\hline & Fraxinus excelsior & B & . & . & + & + & . & + & . & . \\
\hline & Lathyrus vernus/vernus & $\mathrm{C}$ & + & . & . & . & + & + & . & . \\
\hline & Phyteuma spicatum/coeruleum & $\mathrm{C}$ & . & + & + & . & . & + & . & . \\
\hline & & B & . & . & . & . & . & . & + & . \\
\hline & Acer platanoides & $\mathrm{C}$ & . & . & . & . & . & + & 1 & . \\
\hline & Allium ursinum & $\mathrm{C}$ & . & . & . & . & . & + & + & . \\
\hline & Carpinus betulus & A & . & . & . & . & . & $\mathrm{r}$ & + & . \\
\hline & Dryopteris affinis & $\mathrm{C}$ & . & . & . & . & . & . & + & + \\
\hline & Epipactis helleborine & $\mathrm{C}$ & . & + & . & . & + & . & . & . \\
\hline & & B & . & + & . & + & . & . & . & . \\
\hline & Juglans regia & $\mathrm{C}$ & $\mathrm{r}$ & . & . & . & + & . & . & . \\
\hline & Polygonatum multiflorum & $\mathrm{C}$ & . & . & + & . & . & + & . & . \\
\hline QP & Quercetalia pubescentis & & & & & & & & & \\
\hline & Ostrya carpinifolia & A & + & 1 & + & . & + & + & 1 & . \\
\hline & & A & $\mathrm{r}$ & + & $\mathrm{r}$ & . & . & . & . & . \\
\hline & Fraxinus ornus & B & . & . & . & + & + & . & . & . \\
\hline & & $\mathrm{C}$ & + & 1 & + & . & + & + & . & . \\
\hline & Sorbus aria & A & $\cdot$ & + & $\cdot$ & . & $\cdot$ & . & + & . \\
\hline & sorous arta & B & . & . & + & . & . & . & . & . \\
\hline
\end{tabular}




\begin{tabular}{|c|c|c|c|c|c|c|c|c|c|c|}
\hline & Taxa & & 1 & 2 & $3 *$ & 4 & 5 & 6 & 7 & 8 \\
\hline \multirow[t]{2}{*}{$\mathrm{R}$} & Quercetalia robori-petraeae & & & & & & & & & \\
\hline & Pteridium aquilinum & $\mathrm{C}$ & + & + & . & . & + & . & . & . \\
\hline \multirow[t]{8}{*}{ QF } & Querco-Fagetea & & & & & & & & & \\
\hline & Clematis vitalba & $\mathrm{B}$ & + & + & + & + & + & + & + & . \\
\hline & Corvlus avellang & A & . & . & . & . & . & . & . & + \\
\hline & corylus avellana & $\mathrm{B}$ & + & + & + & + & . & + & 1 & . \\
\hline & Anemone nemorosa & $\mathrm{C}$ & + & + & + & . & . & + & + & . \\
\hline & Lonicera xylosteum & $\mathrm{B}$ & . & + & + & + & . & . & . & . \\
\hline & & A & . & . & . & $\mathrm{r}$ & 1 & . & . & . \\
\hline & raxus baccaia & $\mathrm{B}$ & . & . & . & . & + & . & . & . \\
\hline \multirow[t]{2}{*}{ EP } & Erico-Pinetea & & & & & & & & & \\
\hline & Cirsium erisithales & $\mathrm{C}$ & + & . & + & . & + & . & . & . \\
\hline \multirow[t]{15}{*}{ VP } & Vaccinio-Piceetea & & & & & & & & & \\
\hline & & A & 3 & 3 & 3 & 3 & 2 & 2 & 1 & 2 \\
\hline & Abies alba & $\mathrm{B}$ & + & 1 & 1 & 1 & + & 1 & 1 & . \\
\hline & & $\mathrm{C}$ & 1 & + & 1 & 1 & + & + & . & + \\
\hline & Oxalis acetosella & $\mathrm{C}$ & 1 & . & 1 & 1 & 1 & 1 & + & 1 \\
\hline & Solidago virgaurea & $\mathrm{C}$ & + & + & 1 & + & . & + & + & 1 \\
\hline & Gentiana asclepiadea & $\mathrm{C}$ & + & + & + & + & + & + & + & . \\
\hline & & A & 3 & + & 2 & + & + & 1 & + & . \\
\hline & Picea abies & $\mathrm{B}$ & . & . & + & + & + & . & . & + \\
\hline & & $\mathrm{C}$ & . & + & . & + & . & $\mathrm{r}$ & . & . \\
\hline & Rubus hirtus & $\mathrm{B}$ & + & + & 1 & + & + & + & . & . \\
\hline & Calamagrostis arundinacea & $\mathrm{C}$ & + & + & + & + & 1 & . & . & . \\
\hline & Veronica urticifolia & $\mathrm{C}$ & . & . & . & + & . & + & . & + \\
\hline & Blechnum spicant & $\mathrm{C}$ & + & . & + & . & . & . & . & . \\
\hline & Larix decidua & A & $\mathrm{r}$ & . & . & . & $\mathrm{r}$ & . & . & . \\
\hline \multirow[t]{5}{*}{ MA } & Mulgedio-Aconitetea & & & & & & & & & \\
\hline & Senecio ovatus & $\mathrm{C}$ & + & + & 1 & 1 & + & 1 & 1 & 1 \\
\hline & Athyrium filix-femina & $\mathrm{C}$ & 1 & + & 2 & 1 & . & 1 & 1 & 2 \\
\hline & Angelica sylvestris & $\mathrm{C}$ & + & + & + & . & . & . & . & + \\
\hline & Doronicum austriacum & $\mathrm{C}$ & . & . & + & . & . & . & + & 1 \\
\hline \multirow[t]{19}{*}{ AT } & Asplenietea trichomanis & & & & & & & & & \\
\hline & Asplenium trichomanes & $\mathrm{C}$ & . & . & + & + & + & + & + & + \\
\hline & Polypodium vulgare & $\mathrm{C}$ & . & . & . & + & . & . & + & . \\
\hline & Other taxa & & & & & & & & & \\
\hline & Hypericum hirsutum & $\mathrm{C}$ & . & . & + & + & + & . & . & . \\
\hline & Polystichum $x$ luerssenii & $\mathrm{C}$ & . & . & + & . & . & + & + & . \\
\hline & Ajuga reptans & $\mathrm{C}$ & + & . & + & . & . & + & . & . \\
\hline & Polystichum x bicknellii & $\mathrm{C}$ & . & . & . & . & . & 1 & . & 2 \\
\hline & Rubus idaeus & $\mathrm{B}$ & + & . & . & . & . & + & . & . \\
\hline & Viscum album/abietis & A & + & + & . & . & . & . & . & . \\
\hline & Lichens and mosses & & & & & & & & & \\
\hline & Ctenidium molluscum & $\mathrm{D}$ & 1 & + & + & + & 1 & 1 & 1 & + \\
\hline & Fissidens dubius & $\mathrm{D}$ & 1 & + & + & + & 1 & + & . & . \\
\hline & Polytrichum formosum & $\mathrm{D}$ & + & . & + & + & + & + & + & . \\
\hline & Isothecium alopecuroides & $\mathrm{D}$ & . & + & . & + & . & 2 & 1 & + \\
\hline & Neckera crispa & $\mathrm{D}$ & . & . & . & + & + & 2 & + & + \\
\hline & Schistidium apocarpum & $\mathrm{D}$ & . & . & . & . & . & + & + & + \\
\hline & Thamnobryum alopecurum & $\mathrm{D}$ & . & . & + & . & . & + & . & + \\
\hline & Eurhynchium striatum & $\mathrm{D}$ & + & . & + & . & . & . & . & . \\
\hline
\end{tabular}

